\title{
O RISCO PERINATAL (RE) VISITADO: \\ Um estudo da percepção materna sobre a experiência da morte perinatal
}

\section{JOZANA DO ROSÁRIO DE MOURA CAETANO}

Tese de Doutorado apresentada ao Departamento de Saúde MaternoInfantil da Faculdade de Saúde Pública da Universidade de São Paulo para obtenção do Grau de Doutor.

Área de Concentração: Saúde Materno-Infantil

Orientador: Prof. Dr. Arnaldo Augusto Franco de Siqueira

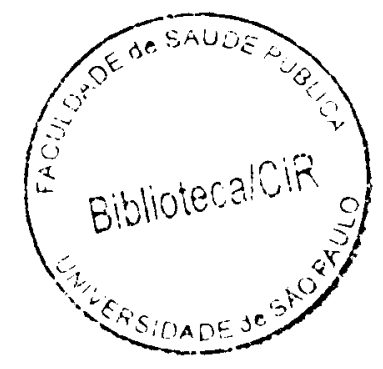


Autorizo, exclusivamente para fins acadêmicos e cientificos, a reprodução total ou parcial desta tese, por processos fotocopiadores.

Assinatura:

Data:

$$
4.2474 / 2 x i 2 \text { die }
$$




\section{A expectativa de Cristina em relação ao nascimento do seu primeiro filho}

"Era uma expectativa muito grande de vê ele. De conhecer meu bebê. de conhecer meu filhote, que eu chamava ele de filhote. Tanto eu como meu esposo, a gente chamava ele de 'meu filhote'. E, a gente tinha uma expectativa grande, saber como é que ele era, de poder vê ele, brincar com ele, de vê ele andando, vê ele brincando. $A$ gente tinha essa expectativa. No caminho da maternidade eu só pensava nisso. 'Como será que vai ser meu bebê? Será que ele vai nascer gordinho? Será que ele vai nascer perfeito?' Eu tinha essa coisa, assim, de querer que ele nascesse logo. Mas depois que eu cheguei lá foi que tudo mudou. Eu vi que não era só isso, não era só um sonho. Que você sentia dor, você sentia medo, você tinha que ter... Era só você e Deus e mais ninguém naquela hora. Se você quisesse vê ele você ia ter que ter... tirar força de você mesmo. Porque ninguém vai lhe ajudar. Depois que eu vi, assim, que as médicas não tavam ligando foi que eu tomei... eu fiz: 'Não, eu tô sozinha. Se eu não fizer força ele não nasce, não vou ter mais meu bebê, não vou vê mais ele. 'Depois que eu cheguei lá que eu me vi sozinha, que eu perguntei pela minha mãe e a enfermeira disse que não podia, que ela não podia entrar, ai foi que o pânico bateu, eu digo 'Meu Deus, e agora? Minha mãe não tá aqui, o que é que eu faço?' Ai eu fiz, 'Não! Eu vou ter esse bebê, eu vou ter.' Mas depois eu fiquei sem força, sem nada, então, depois disso não passou mais nada na minha cabeça. Eu esqueci tudo. Ai, depois só fiquei querendo saber como é que tava o meu bebê, eu queria saber do meu bebê, eu queria vê ele, mesmo do jeito que ele viesse, do jeito que ele tivesse, eu queria vê. Pelo menos vê ele eu queria ter tido visto, mas eu não pude" [Cristina]. 


\section{“Do mítico jardim de éden às sofridas estações do \\ desejo, o trauma alia-se ao \\ ambiente para dar \\ nascimento ao sujeito" \\ $(\text { Delouya })^{l}$}

\section{Dedico esta tese:}

A todas as mulheres, atores principais dessa pesquisa, que ao compartilharem as suas dores suscitaram uma nova dimensão a nossa escuta.

${ }^{1}$ DELOUYA D. Tópica, o negativo da depressão originária. Percurso - Revista de Psicanálise. São Paulo, 21(2):15, 1998. 
Dedico também,

Aos meus pais,

Zequinha e Ana.

A Damião, Juliano e Adriano. 


\section{AGRADECIMENTOS}

\section{Ao Prof. Dr. Arnaldo Augusto Franco de Siqueira}

Sou particularmente grata pela orientação, confiança e apoio irrestrito, oferecido no trajeto da minha formação de pesquisadora em Saúde Pública.

Pela generosidade e respeito no trato com as diferenças.

Aos Profs. Drs. Wilza Vieira Villela e Alberto Olavo Advíncula Reis

Pelas valiosas críticas e contribuições no Exame de Qualificação.

A Profa. Dra. Maria da Penha Vasconcellos

Pelos ensinamentos repassados através da Disciplina "Fundamentos da Investigação Científica", essenciais no despertar do meu interesse pela pesquisa qualitativa em saúde.

Ao Prof. Dr. Rubens de Camargo Ferreira Adorno

Responsável direto, talvez sem perceber, pela minha mudança de percurso metodológico na investigação em Saúde Pública.

A Profa. Dra. Keiko Ogura Buralli (in memoriam)

A minha gratidão pelo acolhimento em momentos aflitivos da produção da pesquisa.

As Profas. Dras. Augusta Thereza de Alvarenga e Ana Cristina d'Andretta Tanaka

Pelos valiosos ensinamentos no campo da saúde reprodutiva da mulher.

A Elba Barreto, Iara Macedo e Leandro Firmino Cleto

Pelos préstimos e consideração durante o periodo em que transitei pelo Departamento de Saúde Materno-Infantil.

Aos Profs. Drs. Maria Luiza Heilborn (UFRJ), Francisco Inácio Bastos (FIOCRUZ) e Rubens Mattos (UERJ)

Pelas contribuições durante a realização do $8^{0}$ Curso de Introdução a Metodologia de Pesquisa em Gênero, Sexualidade e Saúde Reprodutiva.

Aos Profs. Iara Guazelli e Márcio Silva (SEDES SAPIENTIAE)

Pelas orientações em momentos cruciais de definição do objeto de estudo. 
A Profa. Maria do Socorro Amorim

- Chefe do Departamento de Pediatria da UFRN-

Pelo auxílio e solidariedade, determinantes na realização desse projeto acadêmico.

Ao Prof. Luiz de Andrade Viana e Enf. Maria Alvanira Teixeira Nunes Pela colaboração com a pesquisa ao abdicar do seu espaço para realização das entrevistas.

Aos colegas do Departamento de Pediatria da UFRN

Cujo apoio foi fundamental ao desenvolvimento desse processo.

A Secretaria de Estado da Saúde do Rio Grande do Norte, na pessoa da Dra. Maria Goreti Fernandes Cunha

- Coordenadora de Promoção e Saúde -

Pela presteza da sua colaboração, abrindo caminhos para o desenvolvimento inicial do trabalho de campo.

A Secretaria Municipal de Saúde do Município de Natal, na pessoa da Dra. Selma Santiago Nunes

- Chefe Dept ${ }^{o}$. de Planejamento e Informação de Saúde da Secretaria Municipal de Saúde de Natal -

Por ter autorizado e possibilitado o acesso às informações referentes aos óbitos ocorridos em Natal, no periodo de janeiro a julho de 2001.

A Secretaria Municipal de Saúde do Município de Natal, nas pessoas dos Técnicos do Setor de Informação de Mortalidade

Por ter disponibilizado o arquivo e proporcionado as condições necessárias ao levantamento dos dados.

As amizades construídas ao longo do trajeto, Maria Elenita, Adriana, Neide Emy, Maria Luiza, Rosa... e tantas outras Cuja convivência transformou em contentamento momentos dificeis da jornada.

A Isabel Mainetti de Vilutis

Pela escuta atenta aos múltiplos ecos da minha subjetividade. 


\section{RESUMO}

CAETANO, JRM. O RISCO PERINATAL (RE) VISITADO: um estudo da percepção materna sobre a experiência da morte perinatal. São Paulo; 2002. [Tese de Doutorado - Faculdade de Saúde Pública da USP].

Introdução - O enfoque de risco é amplamente utilizado para tomada de decisões relacionadas à assistência à saúde, especialmente à saúde materno-infantil. Oriundos de pesquisas epidemiológicas, tais estudos respondem com eficiência a questões objetivas e de grande abrangência. O modelo de investigação epidemiológica, contudo, não é adequado à análise de aspectos subjetivos, que expressem significados, aspirações, crenças, valores, atitudes, que influenciam o modo de encarar e de proceder diante da vida e da adversidade (doença e morte).

Objetivo - Proceder a uma (re) leitura do risco de morte perinatal partindo da análise da percepção materna sobre a experiência da perda.

Procedimentos metodológicos - Enfoque qualitativo. A pesquisa foi realizada em Natal, Rio Grande do Norte, nos meses de julho e agosto de 2001. Mulheres com registros de perdas perinatais foram localizadas através das Declarações de Óbitos disponiveis na Secretaria Municipal de Saúde de Natal. Entrevistas individuais, com nove mulheres, utilizando roteiro semi-estruturado, foram gravadas. Os dados obtidos foram submetidos à análise de conteúdo.

Resultados e Discussão - A produção de sentido transparece no discurso materno através de termos dotados de significado. Na captação dos termos, evidenciou-se que a presença de acontecimentos indesejáveis e de omissões, instalados nas instâncias assistenciais, contribuiu para as falhas irreversiveis, que implicaram nas perdas ocorridas no decurso da peregrinação da mulher em busca de atenção e de cuidados compativeis com a sua necessidade. A possibilidade de resgatar a experiência e de 
(re) significá-la, demonstrou ser uma particularidade relevante na aplicação do método.

Conclusões - Na situação da perda a percepção materna sobre a morte do filho se expressa através de circunstâncias vivenciais, objetivas e subjetivas. Risco e evitabilidade da morte emergem no discurso materno como categorias localizadas no foco da assistência - no âmbito das relações assistenciais. Destacamos a contribuição do método pela possibilidade de resgatar a experiência, de (re) significá-la.

Descritores: Morte perinatal; percepção materna de risco; saúde da mulher; pesquisa qualitativa. 


\section{ABSTRACT}

CAETANO, JRM. Perinatal risk (re)visited: a study on the mothers' perception of the perinatal death. São Paulo; 2002. [Tese de Doutorado Faculdade de Saúde Pública da USP].

Introduction - The risk approach is widely used for decision taking in health services, especially in maternal and child health. Originated from epidemiological research, such studies respond efficiently to objective and comprehensive questions. The epidemiological research model, however, is not adequate to the analysis of subjective aspects, which express significances, aspirations, beliefs, values or attitudes which influence the way how one envisages and proceed in face of life and adversity (disease and death).

Objective - To perform a (re)reading of the risk of perinatal death starting from the analysis of the maternal perception of the experience of the loss.

Methodological procedures - Qualitative approach. The study took place in Natal, Rio Grande do Norte State, Brazil. The field study was performed in July and August, 2001. Women who suffered perinatal losses were found through the Death Certificates in the files of the Municipal Health Secretary. Individual interviews with nine women, based in a semi-structured plan, were recorded. The author performed a content analysis.

Results and discussion - The production of sense appears in the mothers' speeches through terms with significance. In the search of the terms, it was stated that the presence of undesirable events, and of omissions, in the assistance instances, contributed to irreversible failures which resulted in losses throughout the women's pilgrimage in the search for assistance and care compatible to their needs. The 
possibility of rescuing the experience and of (re)signifying it, showed to be a relevant particularity of the method.

Conclusions - In a situation of a loss, the mother's perception on her baby's death appear in the maternal speech through living circumstances, objective and subjective. Risk and the avoidability of death arise in the mother speech as categories located in the focus of assistance - in the subject of assistance relationships. The author emphasizes the contribution of the method because it permitted to rescue the experience, to (re)signify it.

Key words - Perinatal deaths, maternal perception of risk, women's health, qualitative research 


\section{ÍNDICE:}

Resumo

Abstract

\section{Introdução}

1. Acerca do interesse pelo tema 1

2. A proposta de estudo: perspectivas teóricas 2

1. A morte perinatal e as suas implicações $\quad 9$

1.1 Alguns aspectos conceituais sobre a morte perinatal 9

$\begin{array}{ll}1.2 \text { As causas da morte perinatal } & 10\end{array}$

1.3 Relevância das causas perinatais na mortalidade infantil: magnitude tendência 12

1.3.1 A situação perinatal no mundo, na América Latina e no Brasil 12

$\begin{array}{ll}1.4 \text { Os fatores de risco associados à mortalidade perinatal } & 15\end{array}$

2. Aplicações do conceito de risco 19

2.1 Notas introdutórias sobre a conotação do termo 21

2.2 O enfoque de risco e a sua utilização no campo da saúde 21

$\begin{array}{ll}2.3 \text { Gravidez de risco e risco perinatal } & 27\end{array}$

$2.4 \mathrm{O}$ discurso do risco e a sua adequação à prática: um olhar sobre o serviço de saúde $\quad 31$

$2.5 \mathrm{O}$ risco no discurso social comum 33

3. Abordagem metodológica 36

3.1 Perspectiva de análise qualitativa 36

3.2 O percurso metodológico $\quad 39$

3.2.1 Trabalho de campo e os procedimentos para a coleta dos dados 39

3.2.2 Recursos utilizados para o registro dos dados 42

3.2.3 A transcrição das entrevistas $\quad 44$

3.2.4 A análise dos dados: análise do discurso 46

3.2.4.1 Plano de análise $\quad 48$ 
3.2.4.2 Análise de conteúdo das entrevistas $\quad 48$

3.3 As particularidades do método e o contexto da pesquisa 51

3.3.1 Motivação e expectativa das entrevistadas em participar do estudo 52

$\begin{array}{ll}\text { 3.3.2 Alguns aspectos interacionais do método } & 57\end{array}$

4. As mulheres com história de perda perinatal 61

$\begin{array}{ll}\text { 4.1 Caracterização do grupo estudado } & 61\end{array}$

4.2 Relações sociais e familiares: uma breve configuração 66

4.3 Maternidade: desejo e expectativa $\quad 71$

4.3.1 As manifestações de uma gravidez desejada 73

4.3.2 As manifestações sobre uma gravidez não planejada $\quad 74$

$\begin{array}{ll}4.4 \text { O cuidado } & 77\end{array}$

4.4.1 Situando a utilização do termo cuidado $\quad 77$

4.4.2 Percepção da gravidez: o olhar sobre a concepção e gestação 78

4.4.2.1 Concepção

$\begin{array}{ll}\text { 4.4.2.2 Gravidez } & 80\end{array}$

5. A dimensão da perda perinatal $\quad 89$

$\begin{array}{ll}5.1 \text { Sobre a morte e o morrer: uma breve historiografia } & 89\end{array}$

$5.2 \mathrm{O}$ sentimento materno em relação à experiência da perda perinatal 92

$\begin{array}{ll}\text { 5.3 Dando sentido a perda } & 99\end{array}$

$\begin{array}{ll}5.4 \text { Perspectiva de uma nova gravidez } & 101\end{array}$

6. Produção de sentido na experiência da perda perinatal 106

6.1 Do programa de Assistência Integral a Saúde da Mulher (PAISM) as noções de saúde e direitos reprodutivos 107

$6.2 \mathrm{O}$ parto no contexto da saúde e dos direitos reprodutivos 112

$\begin{array}{ll}6.3 \mathrm{Na} \text { encruzilhada do parto } & 115\end{array}$

6.3.1 Anotações sobre a história da assistência ao parto 116

6.3.2 Considerações clínicas do momento do parto 119

$\begin{array}{ll}\text { 6.3.3 Sobre o trabalho de parto: primeiros relatos } & 121\end{array}$

6.3.4 A percepção da mulher sobre o nascimento e morte do concepto 126 
7.1 Explicação materna da perda

7.2 Enfocando a evitabilidade da morte perinatal 163

$\begin{array}{ll}\text { 7.3 Reflexões preliminares sobre a experiência da perda } & 168\end{array}$

8. (Re) significação do risco perinatal

8.1 Novas feições no tratamento do risco

8.2 A evitabilidade da perda refletindo como espelho o risco de morte perinatal

ANEXOS:

Anexo 1 - Declaração de Óbito

Anexo 2 - Carta convite às mulheres

Anexo 3 - Aprovação pelo Comitê de Ética da FSP

Anexo 4 - Termo de consentimento

Anexo 5 - Roteiro temático das entrevistas

Anexo 6 - Matriz Temática

Anexo 7 - Quadro de análise por entrevista

Anexo 8 - Matriz de Análise

Anexo 9 - Quadro de análise das entrevistas 


\section{Introdução}

\section{Acerca do interesse pelo tema}

Um olhar sobre a ocorrência da morte perinatal a partir da percepção materna, essa é a essência da nossa proposta de estudo.

O nosso interesse pelo assunto foi iniciado na ocasião em que realizávamos o mestrado em Epidemiologia, precisamente durante a elaboração da nossa dissertação, na qual utilizamos o recurso metodológico e de análise dessa área do conhecimento para identificar os fatores associados à gravidade das infecções respiratórias agudas (IRA) e internações hospitalares de crianças menores de cinco anos residentes num dos municípios da Região Metropolitana da cidade de São Paulo.

Na oportunidade, pudemos constatar a relevância atribuída à noção de risco no âmbito da saúde - perpassando todo o campo do saber teórico e prático no domínio da clínica e das ações coletivas de saúde, norteando a definição de políticas e tomadas de decisões nesse campo.

Durante esse processo pudemos também notar a força da estatística, enquanto ferramenta utilizada pela Epidemiologia para análise de dados - fixando modelos explicativos de risco (ou de proteção) à saúde, sendo tais modelos representados por variáveis ou características explicativas da ocorrência de eventos capazes de afetar ou de promover a saúde.

Desde então, a natureza do nosso interesse pelo assunto vem sofrendo modificações. $\mathrm{O}$ acesso a outros referenciais teóricos oriundos das ciências humanas (psicologia, antropologia e sociologia) e da filosofia, e metodológicos - sobretudo 
referentes às abordagens qualitativas, abriram possibilidades para o surgimento de novas questões e novas perspectivas de focalizar alguns dos aspectos considerados cruciais no existir humano, como o adoecer e o morrer.

Tal perspectiva inclui refletir sobre o nexo da articulação entre risco e morte sem perder a dimensão de que existe uma situação geral e uma pessoa especifica, particular, sempre presente. Inclui, além disso, atentar para as diversas dimensões possiveis - constitutivas de identidades e diferenças - do próprio ser ao mesmo tempo fisico, biológico, social, cultural, psíquico, e espiritual como diz MORIN (1994).

O espaço aberto para esse olhar - diferenciado e multidimencional - foi o que permitiu preservar o nosso interesse inicial de proceder a uma (re) leitura do risco de morte em crianças no período designado como perinatal.

\section{A proposta de estudo: perspectivas teóricas}

Em nossa sociedade, a observação empírica revela que a ocorrência do evento morte, apesar de fazer parte da condição humana, é dificilmente aceita. E, quando esta se materializa numa criança torna-se inconcebivel, ocasionando, naqueles que sofreram a perda, sentimentos de frustração, desapontamento, vazio, fracasso, culpa, raiva, revolta, arrependimento, temor, ameaça, insegurança.

Aos sentimentos decorrentes da perda de um filho, apresentados de forma bastante elucidativa por POPIM e BARBIERI (1990), além da expressão de tristeza e pesar, adiciona-se a dificuldade, por parte da mãe e da familia, de compreender as razões que levaram à morte da criança, manifestando-se neles a necessidade de uma explicação, da atribuição de uma causa (clínica, fisiopatológica...), para o 
entendimento do ocorrido. Segundo as autoras, no entanto, muitas das explicações, quando presentes, não são muito convincentes aos olhos da mãe e dos familiares.

Na lacuna instituida pela dificuldade de compreender os acontecimentos, e os sentimentos decorrentes da falta, é de se supor estarem contidas as distintas formas de percepção da realidade (visão de mundo) - moldadas por influência de ações exteriores oriundas do meio sócio-cultural, onde as inúmeras experiências dos individuos se realizam ao longo do tempo - que interferem sobre o modo de encarar e de proceder diante da vida e da adversidade da doença e da morte.

O termo visão de mundo, conforme indicado pelo Novo Dicionário Aurélio, significa a "Compreensão geral do universo e da posição nele ocupada pelo homem, que se expressa por um conjunto mais ou menos integrado de representações e que deve determinar, em última instância, a vontade e os atos de seu portador" (FERREIRA 1999). Por oportuno, estas reflexões nos remetem, apropriadamente, à seguinte passagem do texto de MORIN (1994) “(...) o campo do conhecimento nunca é o campo do objeto puro, mas sim do objeto visto, apercebido, co-produzido por nós, observadores/conceptores. O mundo que nós conhecemos não é o mundo sem nós, é o mundo conosco. (....). ... o nosso mundo faz parte da nossa visão do mundo a qual faz parte do nosso mundo" (p.173).

$\mathrm{Na}$ direção apontada, o problema enunciado nos leva a um breve percurso sobre algumas idéias postas por CHAUÍ (2001, p.117-124) acerca de um pressuposto fundamental, segundo o qual "somos seres racionais conscientes" ou seja, dotados de capacidade humana para conhecer, para saber que conhecemos e para saber o que sabemos que conhecemos. Nesses termos, a consciência significa o conhecimento das coisas e de si, e o conhecimento desse conhecimento, a reflexão. Sob diferentes 
pontos de vista - psicológico, ético e moral, político, e da teoria do conhecimento - a consciência se apresenta, respectivamente, sob quatro modalidades, constitutivas da consciência como subjetividade ativa: o eu, a pessoa, o cidadão e o sujeito. Para a autora, a consciência ativa e reflexiva é aquela que reconhece a diferença entre o interior e o exterior, entre si e os outros, entre si e as coisas. As qualidades exteriores e interiores das coisas, ou seja, dos objetos, e os efeitos internos dessas qualidades sobre nós, representam o conhecimento sensível ou experiência sensivel, o qual se revela sob as formas de sensações e percepções.

Uma abordagem sobre o subjetivismo, como manifestação reveladora de algo externo ao individuo, é argumentada por QUEIROZ (1991) da seguinte maneira, “(...) o indivíduo cresce num meio sócio-cultural e está fundamentalmente marcado por ele" (p.21). Assim, o subjetivismo impresso nos julgamentos e nas reações do indivíduo - relativamente a acontecimentos, necessidades, sentimentos, sensações não é exclusivamente constituído por uma base biológica e psicológica, mas é também mediado pelo meio externo. Quando as sensações se transformam em percepções sofrem, por assim dizer, as imposições do contexto circundante, perdendo, a partir desse momento, o seu caráter de exclusiva subjetividade.

Em adição a essa trajetória reflexiva, SPINK (2000), na sua elaboração intelectual sobre a produção de sentidos no cotidiano, introduz a noção de sentido como sendo “(...) uma construção social, um empreendimento coletivo, mais precisamente interativo, por meio do qual as pessoas - na dinâmica das relações sociais historicamente datadas e culturalmente localizadas - constroem os termos a partir dos quais compreendem e lidam com as situações e fenômenos a sua volta" (p.41). 
Com efeito, a composição dessa trajetória teórica veio ao encontro do fundamento que precisávamos para concretizar a nossa proposta de investigação, qual seja, de fazer uma (re) leitura do risco de morte perinatal, ancorada na apreensão das mulheres sobre a experiência da perda. Nesse sentido, essa proposta assenta a sua análise nas seguintes questões: a) Como as mulheres enunciam e julgam a experiência da perda do seu filho, transcorrida no periodo perinatal? c) De que maneira, para essas mulheres, a perda do filho poderia ter sido evitada? Qual o feitio que a noção de risco assume nas interfaces entre o discurso clínico-epidemiológico e o discurso materno frente à consumação da perda?

A aproximação com a problemática descrita é definida tomando-se como base a captação dos termos (noções) geradores de sentido, presentes no discurso das mulheres que passaram pela experiência da perda do filho no período mencionado. A partir daí, os termos se constituirão na fonte reveladora do sistema integrado de representações acerca da experiência da morte, veiculadas pelo discurso dessas mulheres, sem perder de vista a dinâmica das inter-relações que fazem parte do contexto que as circundaram no processo da experiência.

Assim, na composição do presente trabalho definiu-se como objetivo geral: Proceder a uma (re) leitura do risco da morte perinatal partindo da análise da percepção materna sobre a experiência da perda do filho. Como objetivos específicos foram demarcados os seguintes: a) Apreender a maneira como a morte do filho é descrita e interpretada por mulheres que passaram pela experiência da perda; b) examinar como se apresenta a idéia da evitabilidade da morte no discurso dessas mulheres; c) desvelar interfaces entre o discurso clínico-epidemiológico do risco e os discursos maternos sobre as perdas. 
Ao partir desses objetivos se faz ver que o risco consubstanciado na perda não partilha o mesmo significado atribuído à noção de risco enquanto uma probabilidade da ocorrência de um evento. Pois, na situação de perda, o que era uma possibilidade torna-se experiência; o que estava subordinado a probabilidade transforma-se em evidência; o que era abstrato se converte em realidade sensível; o que antes era capturado como um dado estatístico passa a ser identificado como objeto de reflexão. Na consolidação da perda, o sujeito, antes objetivado pelo discurso do risco, aistórico, transforma-se em sujeito, social e historicamente constituído.

Finalmente, esta tese se estrutura em nove capítulos.

O primeiro capítulo focaliza a morte perinatal na perspectiva médico-sanitária. Faz parte desse capítulo a conceituação da morte perinatal, as causas atribuídas à morte e a relevância do problema do ponto de vista da saúde pública e os fatores considerados de risco para a morte perinatal.

O segundo capítulo introduz noções que embasam o enfoque epidemiológico de risco e a sua utilização na clínica e nas práticas do serviço de saúde. Trata-se, portanto, de uma abertura inicial a essa temática em seus conceitos básicos e de aplicação, a partir da qual se apoiará a nossa reflexão sobre: risco - morte perinatal evitabilidade. Integra ainda esse capítulo a noção de risco no senso comum.

O terceiro capítulo traça o percurso metodológico adotado na pesquisa. A introdução da pesquisadora no campo, o levantamento e tratamentos do material qualitativo da pesquisa, a temática e as categorias analisadas no estudo. Expõem-se ainda as particularidades do método em relação ao contexto da pesquisa - na abordagem sobre motivações e expectativas das entrevistadas relativamente à 
entrevista -, além de apontar alguns aspectos interacionais do método sobre a entrevistada. Nesse momento procura-se configurar os prováveis vieses da pesquisa.

No capítulo quatro faz-se uma apresentação dos atores principais da pesquisa, procurando desvelar as suas particularidades - quem são as mulheres com história de perda perinatal; como se apresentam nas suas relações sociais e familiares; como se manifestam, relativamente à maternidade e gestação; como se conduzem em relação ao cuidado de si e do outro, no que toca à demanda pelos cuidados durante a gravidez.

O capítulo cinco trás à tona a percepção materna da morte, os sentimentos relativamente à perda do filho, atribuição de sentidos à experiência e as perspectivas de uma nova gravidez.

No capítulo seis aborda-se a forma de enunciação e julgamento materno sobre a experiência da perda do filho no contexto do processo reprodutivo da mulher. Focaliza o contexto da experiência - narrativa e circunstâncias da morte - como aconteceu, como foi informada da morte.

O capítulo sete destina-se a interpretação da perda por parte da mulher. Ao que ela atribui a morte do filho, a sua avaliação sobre a assistência recebida durante trabalho de parto e durante o parto e sobre a evitabilidade da morte.

O capítulo oito trata da busca por (re) significar o objeto da presente investigação, a partir da qual se introduz uma nova feição a noção de risco de morte perinatal.

Finalmente, o capítulo nove consiste nas últimas considerações relacionadas à pesquisa. 
Espera-se, que esse trabalho, na sua efetiva aproximação com aspectos da realidade vivida pelas mulheres, se coloque em consonância com as verdadeiras demandas de saúde e dos direitos reprodutivos dessas mulheres. 


\section{A morte perinatal e suas implicações}

\subsection{Alguns aspectos conceituais sobre a morte perinatal}

A morte perinatal inclui os óbitos transcorridos a partir de 22 semanas completas de gestação (154 dias) até o sétimo dia após o nascimento. Na classificação da mortalidade perinatal estão incluidos os óbitos fetais e óbitos neonatais precoces. A presença ou ausência de sinais vitais ao nascer é o aspecto distintivo por excelência entre as mortes fetal e neonatal.

O óbito fetal é considerado pela OMS (1996) como sendo a morte de um produto da concepção, antes da expulsão ou da extração completa do corpo da mãe, independente da duração da gravidez. Dependendo do momento da gestação (idade gestacional) em que se encontre o feto, a morte fetal pode ser classificada como: precoce (menos de 20 semanas de gestação), intermediária (20 a 27 semanas), tardia (28 ou mais semanas). É importante levar em conta que, embora usualmente se designe por nascido morto todo aquele que nasce morto, somente às perdas fetais tardias é que, conceitualmente, se dá a denominação de natimorto (BALDIJÃO e MELLO JORGE 1989). Legalmente, no Brasil, somente às perdas fetais tardias são objeto de sepultamento, com fornecimento obrigatório de atestado de óbito. Portanto, as perdas fetais precoces e intermediárias não se subordinam à obrigatoriedade de registro da morte (LAURENTI e MELLO JORGE 1996).

O óbito neonatal precoce corresponde aos óbitos transcorridos durante a primeira semana de vida. A maioria das mortes neonatais ocorre nesse período, especialmente no primeiro dia de vida (KALUME e col. 1999). 


\subsection{As causas da morte perinatal}

As causas de morte perinatal, de uma maneira geral, apresentam-se vinculadas às condições de saúde, nutrição, nível de escolaridade e de vida da mulher e da familia, assim como ao processo de atendimento durante a gestação, parto, pós-parto e os cuidados imediatos ao recém-nascido.

Comumente, às causas de morte perinatais são atribuídas à prematuridade ${ }^{1}$, ao baixo peso $^{2}$ ao nascer, doenças respiratórias do recém-nascido, síndrome de angústia respiratória, asfixia ${ }^{3}$ intra-uterina e intraparto, traumatismo obstétrico e infecções intra-uterinas. Estas últimas, tidas como importantes causas de morte perinatal, são decorrentes de infeç̧ões transplacentárias devido à ruptura prematura de membranas (KALUME e col. 1999).

Com freqüência alude-se às afecções e complicações maternas - da placenta, cordão umbilical e membranas - a morte perinatal por asfixia. Este agravo, porém, segundo KALUME e col. (1999), pode ser prevenido ainda no pré-natal, através da identificação e tratamento precoces dos fatores desencadeantes. Numa boa parte dos casos, a asfixia também pode ser conseqüência de toco-traumatismos.

\footnotetext{
${ }^{1}$ Prematuridade (pré-termo) designa toda criança nascida com menos de 37 semanas completas (menos de 259 dias) de gestação. (Classificação Internacional de Doenças - CID-10. Versão 1.6c (O)1993 by CBCD e DATASUS) [on line].

${ }^{2} \mathrm{O}$ peso ao nascer é considerado por diversos autores como um dos mais importantes fatores de predição da sobrevivência infantil, e mensuração do crescimento uterino. O peso ao nascer refere-se à primeira medida de peso do feto, ou recém-nascido, obtida após o nascimento.(MELLO-JORGE e col. Sistema de Informações sobre Nascidos Vivos - SINASC. São Paulo, 1992. Série Divulgação ${ }^{0} 7$ ). De acordo com a CID-10 (idem, 1993), considera-se baixo peso o nascimento que apresente peso inferior a $2500 \mathrm{~g}$ (até $2499 \mathrm{~g}$, inclusive).

${ }^{3} \mathrm{O}$ termo asfixia significa sufocação com privação de oxigênio no organismo e aumento sistêmico do dióxido de carbono no sangue e tecidos levando o paciente ao coma (ALVES E. Dicionário Médico: Inglês - Português. Rio de Janeiro, São Paulo: Livraria Atheneu Esditora, 1992).
} 
Outro fator freqüentemente apontado como responsável pelos óbitos perinatais - devido a anóxia ou hipóxia ${ }^{4}$ - é a síndrome hipertensiva materna, da qual se destaca a doença hipertensiva da gravidez (toxemia gravídica), passível de ser detectada e tratada durante o pré-natal. Sendo assim, refere TANAKA 1994 op. cit. SIQUEIRA e col. 1991, “se muitos recém-nascidos falecem por problemas relacionados à doença (....) pode-se inferir que o pré-natal - sua falta ou baixa qualidade -é responsável, em parte, pela situação de saúde perinatal em nosso meio" (p.17).

As causas de óbitos neonatais precoces são muito semelhantes às de óbitos fetais. Estudos realizados têm mostrado que muitas das causas de mortes no atestado de óbito, não correspondem ao verdadeiro problema da morte, já que o preenchimento da declaração de óbito (DO) é feito por profissionais que nem sempre identificam a causa da morte corretamente, sendo "as causas mal definidas" uma das categorias mais utilizadas (MARANHÃO e col. 1998).

No espaço delimitado pelo nosso estudo, essas considerações tornam-se importantes quando se leva em conta que as causas de mortes perinatais no Brasil, diferentemente do que se observa em países desenvolvidos em que a primeira causa de mortalidade nesse período é a malformação congênita, é determinada pelas condições da gestante e pelas circunstâncias do parto e do nascimento.

\footnotetext{
${ }^{4} \mathrm{O}$ termo anóxia significa a ausência ou diminuição de oxigênio nos tecidos do corpo. Hipóxia é a redução da taxa de oxigênio no sangue e nos pulmões (ALVES E. Dicionário Médico: Inglês Português. Rio de Janeiro, São Paulo: Livraria Atheneu Esditora, 1992).
} 


\subsection{Relevância das causas perinatais na mortalidade infantil: magnitude e tendência}

\subsubsection{A situação perinatal no mundo, na América Latina e no Brasil.}

O número 17 da publicação TEMA/RADIS, datada de fevereiro de 99, divulgou na íntegra um documento sobre "A mortalidade Perinatal e Neonatal no Brasil", no qual aborda a tendência da mortalidade perinatal e infantil, os fatores de risco implicados na mortalidade perinatal e as prioridades na intervenção para superar esse grave problema de saúde em nosso País.

A publicação mencionada faz referência a dados apresentados por CAPURRO, médico do Centro Latino Americano de Perinatologia y Desarollo Humano (CLAP/OPS/OMS), no Fórum Nacional de Assistência Perinatal realizado em Brasilia em 1998, segundo o qual 140 milhões de crianças morrem anualmente em todo o mundo, sendo que 7,6 milhões destas mortes ocorrem no período perinatal 4,3 milhões de mortes fetais, após a $22^{\mathrm{a}}$ semana de gestação, e 3.3 milhões de mortes na primeira semana após o nascimento.

De acordo com a mencionada publicação, em sua exposição CAPURRO faz ver que $98 \%$ dos óbitos perinatais ocorrem nos paises com mínimo desenvolvimento ou em países em desenvolvimento onde, segundo ele, uma das dificuldades que apresentam é a falta de organização da assistência materna e perinatal. No Brasil, a taxa de mortalidade perinatal é maior que a média dos países latino-americanos, similar ao Equador e a Guatemala, com indices de 45/1000 nascidos vivos. Somente a Bolivia (55/1000) e o Haiti, este com a maior mortalidade perinatal de toda a América Latina (95/1000), têm taxas piores do que as do Brasil. Cuba e Chile têm a 
menor mortalidade perinatal de toda a América Latina, 15/1000 nascidos vivos. Entre os dados predominantes para a análise da situação perinatal, e, por conseguinte, da mortalidade perinatal, CAPURRO destaca a gravidez na adolescência, o analfabetismo e o baixo peso ao nascer. Segundo LANNES (1999), na maioria desses países $70 \%$ das mulheres freqüenta o pré-natal, o que pode significar que o pré-natal está sendo realizado, mas não está sendo capaz de detectar e intervir nas situações de emergência, ou seja, não tem qualidade nem resolutividade.

KALUME e col. 1999 afirmam que em todas as regiões do Brasil a morte transcorrida no período perinatal representa mais de $72 \%$ da mortalidade neonatal e mais de $50 \%$ dos óbitos no primeiro ano de vida.

Os delineamentos dessa tendência no perfil da mortalidade infantil podem ser notados em dois estudos empreendidos por autores brasileiros, um realizado no município de São Paulo e outro no estado do Rio de Janeiro.

No município de São Paulo, a análise feita por ALMEIDA e col. (1998) referente aos períodos de 1970/1980; 1980/1990 e 1990/1995 revelaram propensão ao declínio dos Coeficientes da Mortalidade Infantil (CMI) nos respectivos períodos, marcadamente no último $(5,6 \%$ ao ano). Neste último período a intensidade maior do declínio deu-se às custas do componente pós-neonatal $(7,4 \%)$ comparada com o componente neonatal $(4,4 \%)$.

LEAL e SZWARCWALD (1996) ao analisarem a distribuição espacial da mortalidade neonatal e seus componentes etários (0-23 horas, 1-6 dias e 7-27 dias) nos municípios do estado do Rio de Janeiro em dois períodos 1979-1981 e 19901992, verificaram que durante a década de 80 processou-se uma transição da mortalidade infantil do seu componente pós-neonatal para o neonatal - decorrente da 
diminuição dos óbitos do primeiro e aumento proporcional do segundo ( 0 a 27 dias). Durante o período, no entanto, a mortalidade neonatal tardia ( 7 a 27 dias) tendeu a apresentar um comportamento semelhante ao da mortalidade pós-neonatal, chegando a produzir impacto nos valores da mortalidade infantil.

Essa transição do componente pós-neonatal para o neonatal, transcorrida na mortalidade infantil na década de 80, segundo LEAL e SZWARCWALD (1996) aponta para a necessidade de conduzir o foco da discussão não apenas para a qualidade da assistência às gestantes, puérperas e recém-natos, mas para a política de saúde implantada, "cujas bases para o enfrentamento desta nova realidade ainda não foram estabelecidas" (p.9). Para as autoras, na década de 90 no Rio de Janeiro, a assistência médica representou o ponto de convergência das políticas de redução da mortalidade infantil, e, neste sentido, a possibilidade da intervenção sobre a mortalidade infantil foi cada vez mais deslocada para a esfera dos serviços de saúde, particularmente os médico-assistenciais, “cujo uso adequado perpassa não só pela possibilidade de acesso, mas também muito intensamente pela decisão e percepção individuais" (p.9).

As questões colocadas por LEAL e SZWARCWALD (199) suscitam, no âmbito da saúde pública a discussão em torno da assistência médica, "reforçando $a$ imbricação da atenção coletiva $e$ individual para cumprir o objetivo de alcançar melhores níveis de saúde para a população" (p.9). Indicam, além disso, "a necessidade de investigações que possam esclarecer o complexo da mortalidade infantil em nossa realidade que, abrindo-se para uma vertente de politica pública e coletiva, precisa para o seu bom exito de cidadãos informados, esclarecidos $e$ exigentes dos seus direitos". (p.9). 


\subsection{Os fatores de risco associados à mortalidade perinatal}

Vários são os estudos que consideram a primeira gestação, multiparidade, gravidez no principio ou no fim da idade reprodutiva, o curto intervalo entre os partos, a perda anterior de filhos e a desnutrição, como fatores universais de risco que aumentam a probabilidade de um mau resultado na gravidez (OMS 1978a).

Segundo a OMS (1978a), em certas circunstâncias, a cultura e os costumes incluindo-se nessas designações, a prescrição ou proibição de certos alimentos no curso da gravidez ou manutenção de práticas anti-higiênicas - e, em determinados casos, o clima, a falta de certos alimentos ou a insalubridade do meio, constituem-se riscos para as mães e para os filhos.

Num estudo longitudinal realizado por MENEZES e col. (1996) para identificar os principais fatores associados à mortalidade perinatal, e de seus respectivos componente fetal e neonatal precoce, de crianças nascidas em Pelotas em 1993, foram detectadas 117 mortes perinatais em 5.304 nascimentos - 55 (47\%) óbitos fetais e $62(53 \%)$ neonatais precoces. Nesse estudo, apresentaram-se associadas à mortalidade neonatal precoce as seguintes características: o sexo masculino, a idade materna igual ou superior a 35 anos, o baixo peso ao nascer e o número de consultas pré-natais inferior a cinco.

No que diz respeito a essa última associação - número de consultas pré-natais e mortalidade perinatal - os autores chamam atenção para o fenômeno de causalidade reversa, ou seja, para aqueles casos em que as mulheres tiveram filhos antes do termo e, por conseguinte tiveram menos tempo de completar o número de consultas recomendado, para tais casos o risco aumentado de morte perinatal não se deve 
exatamente à ausência de consultas por parte das mães, mas à baixa idade gestacional e/ou peso ao nascer (MENEZES e col. 1996).

Um estudo realizado por ALMEIDA e MELO JORGE (1998), no município de Santo André (Região Metropolitana de São Paulo) em 1992, utilizando uma coorte de nascimentos, relaciona os recém-nascidos pequenos para idade gestacional (PIG), ao maior risco de morte neonatal. Por seu turno, a característica PIG mostrou-se associada a outros fatores como a idade materna acima de 35 anos, nível de escolaridade inferior ao primeiro grau completo, e duração da gestação menor de 31 semanas e acima de 42 semanas.

A partir de um estudo caso-controle SIQUEIRA e col (1986) também puderam detectar a influência do estado nutricional da gestante e o hábito de fumar, sobre o crescimento intra-uterino. Nessa pesquisa os autores constaram a relação dessas variáveis com menor crescimento fetal.

É reconhecido em vários estudos que o baixo peso ao nascer é um importante fator determinante de mortes neonatais ocorridas até o sétimo dia de vida (período neonatal precoce). No Brasil, 70\% dos atestados de óbitos em que os pesos ao nascer são notificados, ocorrerem entre os neonatos com peso inferior a $2500 \mathrm{~g}$. Os países desenvolvidos têm taxas de baixo peso ao nascer em torno de $5 \%$ a $6 \%$, enquanto no Brasil, segundo a Pesquisa Nacional sobre Saúde e Nutrição (PNDS-1996), a prevalência de baixo-peso ao nascer foi de $9,2 \%$, e ultrapassa $10 \%$ na zona rural (MARANHÃO e col. 1998).

Segundo MARANHÃO e col. (1998), as precárias condições de vida e a ausência de serviços pré-natais de boa qualidade podem influenciar sobre o baixo peso ao nascer. E, o baixo peso e a idade gestacional servem como indicadores de 
risco para a mortalidade perinatal. Estudos apontam que crianças que nascem prematuras têm maior risco de morrer. No estudo de VICTORA, citado na publicação TEMA/RADIS 1999, 20\% dos recém-nascidos prematuros morreram durante o período neonatal. Entre as mortes analisadas pelo Sistema de Informação de Mortalidade (SIM) no período de 1990 a 1995, cerca de 30\% foram de crianças com menos de 37 semanas de gestação.

No Distrito de Machakos (área rural na Província Oriental do Kenya - África), KAVOO-LINGE e ROGO (1992) ao relacionarem diversas variáveis, tais como: faixa etária. estado marital, escolaridade, status socioeconômico, paridade, local da assistência pré-natal, complicações na gravidez, idade gestacional, tipo de parto, duração do trabalho de parto, e a mortalidade de crianças nas primeiras 24 horas após o parto, verificaram um maior incremento na mortalidade nos extremos superiores de idade materna (idade acima de 40 anos), entre as solteiras e separadas, em relação às casadas, entre mulheres de baixo nível socioeconômico, entre as que apresentaram complicações na gravidez, duração da gestação inferior a 36 semanas, duração do parto acima de 13 horas e tipo de parto diferente do espontâneo. A influência da paridade no estudo mencionado não se mostrou consistente.

A mortalidade neonatal em Recife mostrou ser influenciada pelas condições de saúde materna e que, nesse aspecto as características que mais se destacaram foram àquelas ligadas aos problemas maternos como: doença hipertensiva específica da gravidez, descolamento prematuro da placenta, infecções do trato urinário, representando $84 \%$ do total das doenças identificadas. Considera-se que estas situações, se bem conduzidas e com acompanhamento adequado durante a gestação e 
o parto, podem evitar as mortes tanto dos recém-nascidos como das mães (MARANHÃO e col. 1998).

Numa síntese desse capítulo é possível aduzir que o nascimento é um momento decisivo para a vida ou para a morte do indivíduo. Em adição, a decorrência desse momento também pode levar ao aparecimento ou não de seqüelas após o nascimento, as quais limitarão, em maior ou menor medida, o desenvolvimento do ser humano. 


\section{Aplicações do conceito de risco}

\subsection{Notas introdutórias sobre a conotação do termo risco}

"Risco" é um termo usado com vários sentidos. Uma primeira aproximação sobre o significado do termo risco nos é mostrada pelo Novo Dicionário Aurélio, onde a palavra risco, além do significado de traço ou linha, significa perigo ou possibilidade de perigo. O risco exprime ainda uma situação em que existem probabilidades mais ou menos previsíveis de perda ou ganho, por exemplo, num jogo de azar, ou decisão de investimento. Também é considerado, do ponto de vista jurídico, como a possibilidade de perda ou de responsabilidade pelo dano (FERREIRA 1999),

Outro aspecto também presente na conotação do termo risco refere-se ao "aspecto negativo da possibilidade, o poder não ser" (ABBAGNANO 2000, p.859).

Ao significado do termo risco, além da conotação de perigo (ou ameaça), possibilidade (acaso), chance da ocorrência (ou da não ocorrência) de um evento, previsibilidade (predição), responsabilidade, já comentadas anteriormente, acresce a idéia de medida e de exposição a fatores (fatores de risco), numa situação reconhecida como de insegurança.

Numa busca mais atenta realizada no Novo Dicionário Aurélio é de se notar os múltiplos significados incorporados ao termo risco. Fundamentalmente, os elementos constitutivos do termo conotam a idéia de perigo (circunstância que prenuncia um mal ou estado que inspira cuidado); possibilidade (qualidade de possivel, ou seja, 
que pode acontecer); probabilidade (qualidade de provável, ou seja, que se pode provar, que apresenta probabilidades de acontecer, que tem aparências de verdadeiro. Motivo ou indício que deixa presumir a verdade ou a possibilidade dum fato. Em termos matemáticos, representa um número positivo e menor que a unidade, que se associa a um evento aleatório, e que se mede pela freqüência relativa da sua ocorrência numa longa sucessão de eventos); previsibilidade (qualidade de previsivel, ou seja, que se pode prever antecipadamente; calcular, conjeturar, supor, fazer supor; subentender, pressupor; profetizar, prognosticar, predizer; ver, estudar, examinar, com antecedência; fazer conjeturas; reflexionar, calcular); perda (ato ou efeito de perder, privação de alguém ou de alguma coisa, morte, sumiço); ou ganho (lucro, vantagem, etc.); responsabilidade (qualidade de responsável ou seja, que responde pelos próprios atos ou pelos de outrem; que responde legal ou moralmente pela vida, pelo bem-estar, etc., de alguém, que tem noção exata de responsabilidade; que se responsabiliza pelos seus atos; que não é irresponsável, que dá lugar a, que é causa de algo).

Interessante chamar atenção, rapidamente, para dois aspectos subjacentes à noção de risco, e que estão expressos na conotação do termo responsabilidade, primeiro, um sentido de causalidade e segundo, um sentido mais ligado à atitude individual, comportamental.

Retomando a descrição apresentada pelo Novo Dicionário Aurélio sobre o significado do termo causalidade vê-se que o mesmo denota a qualidade da relação de causa e efeito. Vinculação que relaciona as causas e os efeitos que estas produzem. Num sentido filosófico, causa é um termo correlacionado a efeito e que se concebe de maneiras diversas, que se compreendem a partir de dois enfoques 
fundamentais: 1) relação entre um ser inteligente e o ato que ele praticou voluntariamente e pelo qual é responsável; 2) vínculo que correlaciona os próprios fenômenos e que faz com que um ou vários deles apareçam como condição da existência de outros. Em CEBRIAN (1995), causalidade é a relação que se estabelece entre um fenômeno (causa) com outro que o segue necessariamente (efeito) (p.44).

Todos os termos e conotações mencionadas, de alguma maneira, e, em maior ou menor graus, fazem parte da formulação conceptual de risco utilizada por disciplinas pertencentes ao campo da Saúde Coletiva/Saúde Pública e da Medicina.

Outras disciplinas, além das mencionadas acima, utilizam o conceito de risco como objeto de estudo: Engenharia, Antropologia, Sociologia, Psicologia, Economia.

Por seu turno, a noção de risco também integra o discurso do senso comum.

Em cada uma das propostas teóricas das distintas áreas de conhecimento a utilização do conceito de risco é específica, sendo a aplicação do termo feita para explicar e estabelecer relações com a realidade em planos bastante diversos (MARTIN 1999).

\subsection{O enfoque de risco e a sua utilização no campo da saúde}

AYRES (1997), na sua trajetória por deslindar a configuração históricoepistemológica do conceito de risco e da epidemiologia, identificou as primeiras referências à noção de risco no momento de conformação da epidemiologia moderna, no final do século XIX. Nesse contexto, segundo o autor, "a sua significação aponta para a condição objetiva de sujeição de grupos populacionais a epidemias especificas ou a experiências desfavoráveis à saúde em geral" (p.292). Contudo, o 
conceito ganha força nas duas primeiras décadas do século $\mathrm{XX}$, com as transformações ocorridas no campo das ciências da saúde, incluindo o surgimento da imunologia e da epidemiologia. Essa primeira fase é designada pelo autor como "epidemiologia da constituição".

Um segundo momento histórico delimitado por AYRES (1999) surge quando a epidemiologia moderna passa a assumir um caráter mais estritamente vinculado às ciências biomédicas, estabelecendo uma intermediação teórica entre as ciências relativas aos processos patológicos orgânicos e os comportamentos coletivos dos fenômenos da saúde. Sob o enfoque de uma "epidemiologia da exposição, o risco assume um lugar de maior destaque, vindo a constituir um conceito essencialmente analítico, referido às condições de susceptibilidade individual determinantes do comportamento epidêmico das doenças infecciosas" (p.293). Na situação apontada, ao invés de qualificar uma condição populacional, como feito anteriormente, o risco passa a indicar uma relação determinada entre fenômenos individuais e coletivos. Nesse lugar, o risco já não qualifica uma condição populacional, mas indica uma relação determinada entre fenômenos individuais e coletivos.

Numa terceira fase, identificada por AYRES (1997) como "epidemiologia do risco", iniciada a partir da II Guerra Mundial, o risco alcança a plenitude de sua formalização e assume a centralidade do discurso epidemiológico. Acentua-se nessa etapa a dependência à validade dos enunciados postos pela epidemiologia ao conhecimento das ciências biomédicas, ao mesmo tempo em que se expande a legitimação de suas inferências observacionais. A epidemiologia dimensiona o seu progresso conceitual aos aspectos tecnometodológicos, de evidente versatilidade e penetração. Diz o autor, "O risco assume um papel marcadamente especulativo $e$ 
imediatamente quantificado. O conceito passa a designar chances probabilísticas de susceptibilidade, atribuiveis a um individuo qualquer de grupos populacionais particularizados, delimitados em função da exposibilidade a agentes (agressores ou protetores) de interesse técnico ou cientifico" (294). Esse periodo, segundo o autor, marca uma grande expansão institucional da disciplina epidemiológica. Porém, no plano das práticas de saúde fica evidente um marcante retrocesso das abordagens médico-sociais, com relevo sobre a "privatização" nos planos ideológicos, políticos e econômicos das concepções e práticas de assistência à saúde de um modo geral.

Não obstante, são inegáveis as várias conquistas em termos de conhecimento do risco em saúde (CASTIEL 1999). Nesse sentido, diz AYRES (1997) referindo-se a MENDES-GONÇALVES (1990), o paradigma do risco abriu uma série de novas e relevantes possibilidades para o conhecimento epidemiológico e para as relações com a medicina, de um modo geral.

Na assistência à saúde e, em particular, a saúde da mulher e da criança, o emprego do conceito de risco, segundo ALVARENGA (1987), aparece na literatura especializada dos países desenvolvidos a partir da segunda metade década de sessenta. No contexto do seu surgimento apresenta-se como elemento de articulação da clínica (obstétrica e pediátrica) e de saúde pública para tratamento de questões relacionadas com a morbimortalidade perinatal, cuja análise se torna possível com o aparecimento da noção de "risco gravídico"s. O emprego do conceito de risco,

\footnotetext{
5 "Risco gravidico" é um termo utilizado na área materno-infantil para designar caracteristicas vinculadas à morbidade e mortalidade perinatal. Esse termo teve a sua origem na década de trinta integrando um sistema teórico da prática médica onde, as concepções de gestação normal e patológica passam a atrelar-se às noções de padrões de crescimento intra-uterino normal e patológico. (ALVARENGA AT. Risco gravídico e risco perinatal: implicações metodológicas, teóricas e técnicas, das propostas de mensuração. Rev. Bras. Cresc. Des. Hum. IV(2):41-48,1994).
} 
pautado na mensuração dos níveis de risco gravídico, põe em evidência a necessidade de uma assistência diferenciada à mulher considerada de "alto risco" .

De acordo com a autora, o emprego do conceito de risco foi definido "no interior do movimento de recomposição da prática médica denominado 'Medicina Comunitária" (p.19) nos Estados Unidos, tendo surgido para conciliar os interesses oriundos "de uma medicina tecnológica e hegemônica, com aqueles relativos aos de uma medicina preventiva e integral (....)" (p.19). Porém, nos paises denominados do Terceiro Mundo o "Enfoque de Risco" só se introduziu a partir da década de setenta, como “' Estratégia de Intervenção' no campo da administração de serviços” (p.19), em concomitância com a proposta inovadora sobre "Cuidados Primários de Saúde", oriunda da conferência internacional realizada em Alma-Ata em 1978. Dessa forma, a aplicação do conceito de risco assumiu novas especificidades como instrumento de planejamento e administração no campo da saúde pública.

Vale ressaltar que grande quantidade de investigações sobre a temática do risco nas últimas décadas tornou-se possível, em parte, pela ampliação do acesso à tecnologia computacional e aos pacotes estatísticos (CASTIEL 1999).

Tanto em epidemiologia quanto em saúde pública, risco se define em termos teóricos e estatísticos como sendo a probabilidade de que um fenômeno indesejado ou dano possa ocorrer. O dano pode ser considerado o surgimento ou a existência de um processo patológico ou de complicações desse processo (PLAUT 1984). Para o

\footnotetext{
"Enquanto expressão de risco para o concepto, a noção de "alto risco" assume fundamental importância na década de 50 na área Materno-Infantil, a partir da articulação da clínica obstétrica com a pediatria, instituindo-se um novo campo do conhecimento médico, a Perinatologia. De então, surgem a necessidade da definição de novos termos, visando a sua utilização como indicadores (ou fatores) de risco para a mortalidade e morbidade neonatal e infantil, e com as questões da mensuração de risco gravídico e a sua aplicação no campo da Saúde Materno-Infantil, notadamente em função das perspectivas relacionadas a incorporação da prática médica no interior do campo da Saúde Pública, na década de 60. (ALVARENGA AT. O conceito de risco gravídico e a questão perinatal. São Paulo, Série de Investigação em Saúde da Mulher, da Criança e Adolescência, 3:29-39, 1994).
} 
autor, risco é a probabilidade de que esse processo ou a sua complicação ocorra ou exista. Na prática, diz ele, a estimativa do risco é feita através de taxas de incidência e prevalência quando o dano corresponde a uma enfermidade, síndrome ou complicação, e de taxa de mortalidade quando o dano corresponde a morte.

$\mathrm{Na}$ epidemiologia o risco é um termo central, "o mais particular $e$ característico da epidemiologia moderna" como refere AYRES (1997).

É notório nos textos básicos de epidemiologia o caráter tecno-operacional que o conceito de risco assume, no qual é conferido o maior interesse à dimensão da probabilidade. Segundo ALMEIDA FILHO (1989) o “Risco é o correspondente epidemiológico do conceito matemático de probabilidade. Portanto, risco pode ser definido como a probabilidade de um membro de uma população definida desenvolver uma dada doença em um periodo de tempo" (p.24).

Em LAST (1995), "risco é a probabilidade de um individuo tornar-se doente ou morrer num periodo de tempo ou idade" (p.148). FLETCHER e WAGNER (1996) referem-se ao risco como a "probabilidade de pessoas expostas a certos fatores ('fatores de risco') adquiram subseqüentemente uma determinada doença" (p.103). Nesta acepção, a idéia de probabilidade apresenta uma conotação objetiva, racional, precisa mediante técnicas probabilísticas, de incerteza mensurável segundo GIFFORD (1986) citado por CASTIEL (1999). Esta noção de probabilidade, que dá respaldo à idéia de fatores de risco, é utilizada pela epidemiologia através do dispositivo estatístico. Dentro dessa abordagem os fatores de risco são considerados marcadores que visam a predição de uma morbimortalidade futura.

Assim, a noção de fatores de risco se introduz como sendo características que estão associadas a um maior risco de adoecer (FLETCHER e WAGNER 1996) e de 
morrer. Esse termo, segundo CEBRIAN (1995), inclui o nível econômico, social, biológico, a conduta e outros estados conhecidos por estarem associados (ou serem causas do aumento da susceptibilidade a uma enfermidade específica) a um precário estado de saúde ou a um acidente.

Portanto, fator de risco refere-se a qualquer fenômeno de natureza física, química, orgânica, psicológica ou social que, pela variedade da sua presença ou ausência, está relacionado com o surgimento de uma enfermidade, ou pode ser a causa que contribui com o seu aparecimento em determinadas pessoas em um lugar e tempo especificados FLETCHER e WAGNER (1996). Mesmo que um fator de risco não cause a doença, referem os autores, a sua presença permite predizer a probabilidade de que a mesma venha a ocorrer.

Uma medida de risco, segundo BACKETT e col. (1985), é um intimador da necessidade de assistência promotora e preventiva, e o conhecimento da situação antes de ocorrer o evento previsto proporciona tempo para uma resposta adequada. Neste sentido, o conhecimento dos fatores de risco é também usado para melhorar a eficiência de programas de rastreamento pela seleção de subgrupo de pacientes com maior risco, asseveram FLETCHER e WAGNER (1996). Delineia-se nesse último propósito do estudo epidemiológico do risco mais um termo correlato que é o de grupo de risco.

BACKETT e col. (1985) afirmam que os fatores de risco podem caracterizar o indivíduo, a família, o grupo, a comunidade ou o ambiente. No que toca à reprodução, por exemplo, a primeira gestação, a gravidez na adolescência ou depois dos 40 anos, a multiparidade, o pequeno intervalo entre as gestações, a perda anterior de filhos, a desnutrição e a deficiência dos serviços obstétricos são, segundo os 
autores, fatores de risco que aumentam as probabilidades de várias ocorrências indesejáveis da gravidez.

Segundo PLAUT (1984) a análise de risco é também capaz de oferecer elementos decisivos na avaliação e seleção das tecnologias de intervenção apropriadas para prevenir e reparar os danos à saúde. Para o autor, porém, o impacto que uma tecnologia pode ter para reduzir a magnitude de um dano dependerá em parte da sua eficácia intrínseca e em parte da eficiência da sua aplicação. Para tornar-se apropriada ela não só necessita ser eficaz, mas deve satisfazer requisitos de eficiência social próprios de cada pais; deve ser técnica e economicamente factível e política e culturalmente viável.

Diante da noção de fatores de risco a medicina passou a desempenhar com mais relevo a função de prevenção dos agravos à saúde, o que pode ser conferido através da enorme "proliferação de produtos, profissionais e serviços voltados para essa perspectiva em que (ainda?) não há doença, nem doentes" (CASTIEL 1999, p. 140).

Em síntese, é nessa perspectiva que o conceito de risco se torna aplicável dentro dos seus propósitos científicos e operacionais (ALMEIDA FILHO, 1989). E, é baseada nessa noção - essencial ao raciocínio epidemiológico - que o risco torna-se categoria fundamental de intervenção prática, mantendo-se em constante diálogo com a clínica e saúde pública, e na prevenção da enfermidade e da morte.

\subsection{Gravidez de risco e risco perinatal}

A gestação é um fenômeno fisiológico e, por essa razão, comumente, evolui sem intercorrências. Mesmo assim, "há pequena parcela de gestantes que, por terem 
características específicas, ou por sofrerem algum agravo, apresenta maiores probabilidades de evolução desfavorável, tanto para o feto como para a mãe. Esta parcela constitui o grupo chamado de gestantes de alto risco" (BRASIL 2000a, p.9).

ALVARENGA (1994), ao se referir à literatura analisada em sua investigação sobre risco gravídico e a questão perinatal, afirma ser na gravidez denominada de "alto risco" que se busca, de maneira específica, a explicação para as causas de prematuridade, de insuficiência ponderal ao nascer, de mortalidade fetal e neonatal precoce.

A designação "alto risco" refere-se ao gradiente máximo de necessidade de cuidado na assistência ao indivíduo que apresenta alta probabilidade de sofrer alterações de saúde no futuro. Sendo assim, as necessidades do grupo considerado de "alto risco" requerem técnicas mais especializadas de atenção, enquanto o grupo de "baixo risco" é tratado, geralmente, com procedimentos simples (primeiro nível de assistência). Esta abordagem discriminatória e definidora das necessidades serve de fundamento às normas de assistência materno-infantil segundo o grau de risco apresentado pelo indivíduo. Dessa forma o controle pré-natal de uma gestante considerada de baixo risco será diferente do de uma de alto risco, seja em objetivos, conteúdos, número de consultas pré-natais e tipo de pessoal que presta assistência. (BRASIL 1991, p.6).

CALDEYRO-BARCIA (1973) referido em BRASIL (2000a), define a gestação de alto risco como sendo "aquela na qual a vida ou a saúde da mãe e/ou do feto e/ou do recém-nascido tem maiores chances de serem atingidas que as da população considerada". 
No contexto da gestação de risco duas situações são levadas em conta: 1) A mulher apresentar condições de saúde ou psicossociais comprometidas antes da gestação; 2) A mulher vir a ter comprometimento dessas condições posteriormente, no processo da gravidez (TEDESCO 1997).

$\mathrm{Na}$ prática clínica recomenda-se que, no seguimento da gravidez de alto risco, os seguintes aspectos sejam considerados: a) Repercussões mútuas entre doença e gravidez; b) Avaliação clínica; c) Avaliação obstétrica e fetal; d) Necessidade de antecipação do parto. Além destes aspectos ressalta-se ainda a importância do componente emocional no seguimento da gravidez de alto risco (BRASIL 2000a).

Também se deve levar em conta a possibilidade da ocorrência de complicações no curso de uma gestação considerada normal, transformando-a em gestação de alto risco. Por isso, "logo no inicio do pré-natal, e durante toda a gestação, deve-se proceder a uma 'avaliação de risco' das gestantes de modo a identificá-las no contexto amplo de suas vidas e mapear os riscos a que estão expostas" (BRASIL 2001).

Conforme especificação feita no Manual Técnico de Gestação de Alto Risco (BRASIL 2000a) os fatores geradores de risco podem ser agrupados em quatro grupos:

1. Características individuais e condições sócio-demográficas desfavoráveis;

2. História reprodutiva anterior à gestação atual;

3. Doenças obstétricas na gestação atual;

4. Intercorrências clínicas. 
Os fatores de risco à gravidez acham-se detalhados no quadro a seguir:

Quadro 1 - Fatores de risco na gravidez (Tedesco, 1999)*

\begin{tabular}{|c|c|c|c|}
\hline $\begin{array}{l}\text { Características } \\
\text { individuais e condições } \\
\text { sócio-demográficas } \\
\text { desfavoráveis }\end{array}$ & $\begin{array}{l}\text { História reprodutiva } \\
\text { anterior }\end{array}$ & $\begin{array}{l}\text { Doença obstétrica na } \\
\text { gravidez atual }\end{array}$ & Intercorrências clínicas \\
\hline $\begin{array}{l}\text { - Idade menor do que } 17 \\
\text { e maior que } 35 \text { anos; } \\
\text { - Ocupação: esforço } \\
\text { físico. carga horária } \\
\text { rotatividade de horário, } \\
\text { exposição a agentes } \\
\text { fisicos, quimicos e } \\
\text { biológicos nocivos. } \\
\text { estresse; } \\
\text { - Situação conjugal } \\
\text { insegura; } \\
\text { - Baixa escolaridade: } \\
\text { - Condições ambientais } \\
\text { desfavoráveis; } \\
\text { - Altura menor que } 1.45 \\
\text { m; } \\
\text { - Peso menor que } 45 \mathrm{~kg} \\
\text { e maior que } 75 \mathrm{~kg} \text { : } \\
\text { - Dependência de drogas } \\
\text { lícitas e ilícitas. }\end{array}$ & $\begin{array}{l}\text { - Morte perinatal } \\
\text { explicada e inexplicada } \\
\text { - Recém-nascido com } \\
\text { crescimento retardado, } \\
\text { pré-termo ou } \\
\text { malformado; } \\
\text { - Abortamento habitual; } \\
\text { - Esterilidade e/ou } \\
\text { infertilidade; } \\
\text { - Intervalo interpartal } \\
\text { menor que } 2 \text { ou maior } \\
\text { que } 5 \text { anos; } \\
\text { - Nuliparidade e } \\
\text { multiparidade; } \\
\text { - Síndrome hemorrágica } \\
\text { ou hipertensiva; } \\
\text { - Cirurgia anterior. }\end{array}$ & $\begin{array}{l}\text { - Desvio quanto ao } \\
\text { crescimento uterino. } \\
\text { número de fetos e } \\
\text { volume de líquido } \\
\text { amniótico; } \\
\text { - Trabalho de parto } \\
\text { prematuro e gravidez } \\
\text { prolongada; } \\
\text { - Ganho ponderal } \\
\text { inadequado; } \\
\text { - Pré-eclâmpsia e } \\
\text { eclâmpsia; } \\
\text { - Diabetes gestacional; } \\
\text { - Amniorrexe prematura; } \\
\text { - Hemorragias da } \\
\text { gestação; } \\
\text { - Aloimunização; } \\
\text { - Óbito fetal. }\end{array}$ & $\begin{array}{l}\text { - Hipertensão arterial; } \\
\text { - Cardiopatias; } \\
\text { - Pneumopatias; } \\
\text { - Nefropatias; } \\
\text { - Endocrinopatias; } \\
\text { - Hemopatias; } \\
\text { - Epilepsia; } \\
\text { - Doenças infecciosas; } \\
\text { - Doenças autoimunes; } \\
\text { - Ginecopatias. }\end{array}$ \\
\hline
\end{tabular}

No quadro apresentado, verifica-se que a maioria dos fatores de risco mencionada refere-se a características próprias da mulher, e, sendo assim, a avaliação de risco durante a gravidez encontra-se centralizada nesses aspectos.

Não obstante, SIQUEIRA (1994a) aludindo os resultados de sua investigação sobre aspectos nutricionais em gestantes verificou uma "altissima mortalidade perinatal", resultante de complicações na gravidez e no parto como: "inalações graves de mecônio, eclampsias, e outros", relacionadas a questões de natureza assistencial. Nesse sentido, os serviços não podem ser ignorados no que toca à saúde e aos riscos materno e perinatal. 


\subsection{O discurso do risco e a sua adequação à prática: um olhar para o serviço de saúde}

KALUME (1999) refere que os serviços de saúde também podem ser analisados dentro do enfoque de risco, em relação a acesso e qualidade do atendimento prestado. Nessa perspectiva, um aspecto a ser realçado na assistência às crianças no país é a adoção crescente de novas tecnologias, permitindo a sobrevivência de crianças cada vez mais prematuras, assistidas em UTI neonatais.

De acordo com a autora essas intervenções deveriam estar concorrendo para a diminuição da morbimortalidade neonatal. Porém, quando se observa a mortalidade causada pela doença da membrana hialina em UIT neonatais no Brasil nota-se que esta é 4 a 5 vezes maior do que em paises desenvolvidos. Essa diferença pode decorrer de muitos fatores, entre os quais: menor quantidade de recursos, superlotação. deficiência nos cuidados básicos para o recém-nascido (como termoregulação, alimentação e prevenção de infecções), além da falta de treinamento dos recursos humanos dos serviços de saúde. ${ }^{7}$ Em contra-partida, a demanda por tecnologia sofisticada poderia ser reduzida, se houvesse um adequado monitoramento da mulher durante o período gestacional, identificando e reduzindo os riscos na gravidez e no parto.

A respeito disso TANAKA (1994) chama atenção para três aspectos relacionados à problemática da atenção pré-natal em nosso país: primeiro a questão

\footnotetext{
${ }^{7}$ Num estudo de revisão utilizando registros de nascimentos e óbitos fetal e neonatal ocorridos no Hospital de Clínicas de Porto Alegre, MIURA e col. (1997) puderam constatar que os avanços tecnológicos e a capacitação de pessoal médico e de enfermagem nos cuidados intensivos neonatais não provocaram redução nos coeficientes de mortalidade neonatal. Apenas uma tendência ao declínio no grupo de recém-nascidos com peso inferior a 1.500 gramas. Houve aumento nas causas de morte por infecções pós-natais ou hospitalares. (MIURA E, FAILACE LH, FIORI H. Mortalidade perinatal e neonatal no Hospital de Clínicas de Porto Alegre. Rev. Ass Méd Brasil, 43(1)35-39, 1997).
} 
da demanda e acesso ao serviço de saúde, segundo a qualidade da assistência relativamente à deteç̧ão precoce de problemas durante a gravidez e terceiro a problemática da hierarquização e regionalização do serviço - por exemplo, a ligação do serviço pré-natal com hospital. Para a autora, no plano assistencial é preocupante a inexistência de um sistema de referência à parturiente no momento do parto, levando muitas vezes a peregrinação da mulher por diversos hospitais em busca de atendimento. Com respeito à qualidade do atendimento infere a relação entre o tempo de admissão e o primeiro exame obstétrico e a qualidade da assistência ao parto.

No momento do parto e no pós-parto, a qualidade da assistência é considerada de fundamental importância para a redução da morbimortalidade perinatal e materna. A cobertura do parto em instituição de saúde, em nivel nacional, segundo KALUME (1999) referindo-se à Pesquisa Nacional de Demografia e Saúde (PNDS 1996), alcança $91,5 \%$. Apesar de considerada uma alta cobertura, ainda persiste a baixa qualidade de atendimento.

SIQUEIRA (1994b) também atribui os problemas que afetam a saúde perinatal a questões ligadas à qualidade da assistência e acessibilidade aos serviços de saúde. Nesse sentido, chama atenção para o valor metodológico e estratégico de um outro aspecto, relativo à saúde perinatal - concernente à produção de conhecimento, à melhoria das condições de trabalho e de saúde - que é a integração ensino/serviço.

No que toca à avaliação da qualidade dos serviços de saúde, um outro aspecto importante a ser considerado é a ocorrência de óbitos em crianças que não apresentam nenhum dos fatores de risco descritos para a mortalidade infantil. Vale informar que isso ocorre com aproximadamente um quarto dos óbitos neonatais que não apresenta história de prematuridade nem baixo peso ao nascer (KALUME 1999). 
Nesse sentido, torna-se necessário ressaltar que os conceptos no período mais vulnerável das suas vidas acham-se expostos aos riscos de adoecer e morrer não apenas por problemas orgânicos, mas, principalmente por fatores ligados à qualidade da assistência no pré-natal, no parto e no período neonatal precoce (TANAKA 1994).

\subsection{O Risco no discurso social comum}

Do ponto de vista semântico o termo senso comum compreende um "conjunto de opiniões e modos de sentir que, por serem impostos pela tradição aos indivíduos de uma determinada época, local ou grupo social, são geralmente aceitos de modo acrítico como verdades e comportamentos próprios da natureza humana" (FERREIRA 1999).

Para CHAUÍ (1996, 1997), o senso comum compreende um conjunto de crenças, valores, saberes, atitudes julgadas naturais, porque são transmitidas de geração a geração. O senso comum é a realidade como transparência: nele tudo está explicado e em seu devido lugar. Uma, dentre seis, das características do senso comum, citada pela autora, é ser causalista, ou seja, estabelecem relação de causa e efeito entre as coisas, as pessoas ou os fatos.

Na linguagem filosófica contemporânea, segundo LALANDE (1999), o senso comum é o conjunto das opiniões tão geralmente admitidas, numa dada época e num dado meio, que as opiniões contrárias aparecem como aberrações individuais, inúteis de se refutar seriamente.

No âmbito do discurso social comum o termo risco reveste-se de um forte componente subjetivo quando se associa à percepção, sensação ou sentimento de presença (ou potencial) de um perigo, diz ALMEIDA FILHO (1997). Nesse espaço, 
a idéia de probabilidade apresenta um caráter intuitivo, subjetivo, ligado a um grau de crença, isto é, uma incerteza não-mensurável segundo GIFFORD (1986) citado por CASTIEL (1999). Além disso, em relação ao sujeito que o enuncia, o lugar do risco no discurso social comum, geralmente, está situado "fora do sujeito que fala, carregado por condutas ou localizado em fontes no ambiente" (ALMEIDA FILHO 1997 p.127).

Esta localização do risco "fora do sujeito que fala", já se fazia presente, segundo ABBAGNANO (2000), nas filosofias que reconhecem o possível. Em Aristóteles, por exemplo. o risco era considerado como 'o aproximar-se daquilo que $e ́$ terrível'. Já em Platão, o risco apresentava-se como "belo e inerente à aceitação de certas hipóteses ou crenças" (p.859).

GIDDENS (1991) faz referência a íntima relação entre risco e perigo. Em seu dizer o risco pressupõe o perigo, não necessariamente a consciência do perigo. Para ele, uma pessoa que arrisca algo coteja o perigo onde o perigo é compreendido como uma ameaça aos resultados desejados. Contudo, o indivíduo pode assumir ações ou estar sujeito a situações que são inerentemente arriscadas estando ou não consciente. Qualquer um que assume um "risco calculado" está consciente da ameaça ou ameaças que uma linha de ação específica pode por em jogo. Mas é certamente possível assumir ações ou estar sujeito a situações que são inerentemente arriscadas sem que os indivíduos envolvidos estejam conscientes do quanto estão se arriscando.

$\mathrm{Na}$ filosofia existencial, o risco é tido como "inerente à escolha que o eu faz de si mesmo e a toda decisão existencial", refere ABBAGNANO (2000 p.859). Para este autor, a aceitação do risco implícito na escolha que o eu faz de si mesmo e a toda decisão existencial é um dos pontos fundamentais do existencialismo 
contemporâneo: “'A pretensão implícita na decisão baseia-se numa indeterminação efetiva, ou seja, na possibilidade de que as coisas se passem de maneira diferente daquilo que eu decido; mas também se baseia no fato de eu, que decido, assumir esse risco, bem como na consideração de todas as possiveis garantias que eu possa obter" $^{\text {" }}$. 859).

Portanto, as conotações subjacentes à noção de risco podem ser remetidas a diversas situações experimentadas no cotidiano da sociedade moderna: o risco de contrair doenças, de acidentes, de violência, riscos na economia, na política (MARTIN 1999); riscos pelo "prazer da aventura", do desconhecido, pela busca de ação e emoção, pelo prazer de correr riscos, pelo prazer de saber, como diz BUENO (2001).

De acordo com MARTIN (1999), o risco é um termo que tem um grande apelo no senso comum, pela divulgação de pesquisas científicas sobre fatores de risco em meios de comunicação, com objetivos informativos de prevenção, diagnóstico e tratamento.

É no discurso social comum que se encontra a matriz de significações no processo de construção dos discursos técnicos e dos discursos científicos (ALMEIDA FILHO, 1997). 


\section{Abordagem metodológica}

\subsection{Perspectiva de análise qualitativa}

A palavra qualitativa implica uma ênfase nos processos $e$ objetivos não rigorosamente examinados ou medidos em termos de quantidade, intensidade ou freqüência. Os métodos qualitativos enfatizam as especificidades de um fenômeno em termos de suas origens e de sua razão de ser (HAGUETTE 1999).

O trabalho da pesquisa qualitativa, segundo MINAYO (1999), é com o universo de significados, motivos, aspirações, crenças, valores e atitudes, o que corresponde a um espaço mais profundo das relações, dos processos e dos fenômenos que não podem ser reduzidos à operacionalização de variáveis. Para MINAYO (1992), a pesquisa qualitativa torna-se importante para: a) compreender os valores culturais e as representações de determinado grupo sobre temas específicos; b) para compreender as relações que se dão entre atores sociais, tanto no âmbito das instituições como dos movimentos sociais; para avaliação das políticas públicas e sociais tanto do ponto de vista da sua formulação, aplicação técnica, como dos usuários a quem se destina.

Para DENZIN e LINCOL (1994) "a pesquisa qualitativa tensiona a natureza do socialmente construido da realidade, a intima relação entre o pesquisador e o que está sendo estudado. Na pesquisa qualitativa procura-se responder questões que tensionam o como a experiência social é criada e dado significado” (p.4). 
A pesquisa como prática social, conforme foi expressa anteriormente, aponta para o reconhecimento crescente da responsabilidade do pesquisador durante todo o processo da pesquisa, sem perder de vista que, na relação pesquisador/pesquisado,

"O processo de aproximação entre sujeito e objeto coloca em relação duas espécies de intencionalidades: a do sujeito que procura conhecer e a do sujeito/objeto de conhecimento. Assim sendo, o investigador se depara, no seu processo de pesquisa, com um objeto que reage à sua presença, detém um saber que lhe é próprio decorrente da sua experiência de vida, capaz de atribuir significados as suas ações $e$ ao seu discurso, expressando $e$ articulando seus pensamentos a sua maneira (....)." (BRIOSCHI e TRIGO 1987, p. 633).

Portanto, nessa relação o pesquisador não se apresenta como observador neutro, pois ele mesmo leva para a situação da entrevista, entre outras coisas, a sua posição social, formação cultural, profissional, etc. Em decorrência, a problematização inerente à situação relacional da entrevista implica em tomada de consciência por parte do pesquisador acerca das interferências que possam alterar a captação dos dados, e que devem ser consideradas no trabalho de análise e de interpretação.

Dessa forma, a busca dos elementos comuns põe, então, em evidência o caráter processual da pesquisa - numa aceitação plena do dinamismo, historicidade e contextualidade implícita do nosso conhecimento sobre o mundo. Põe em evidência, ainda a dialogia e intersubjetividade intrínseca do processo de pesquisa. (SPINK e MENEGON 2000).

Nessa medida, o campo de investigação em Saúde Pública abre amplas perspectivas e possibilidades de análise dos problemas que apresenta.

Assim, para efeito da nossa proposta de captar as noções impressas na percepção materna sobre experiência da morte do filho, e as relações aí 
estabelecidas, conduziremos o eixo da nossa análise para a identificação das categorias presentes nas falas das mulheres envolvidas na pesquisa, e a sua utilização de forma situada no discurso.

Tal proposta se aproxima da argumentação posta por DEREK (1991) citada por SPINK e MENEGON (2000), na qual, segundo as autoras o estudo das categorizações pode ser muito rico se as categorias forem compreendidas como práticas discursivas ${ }^{8}$ situadas. Nesse modo de compreender, produz-se um deslocamento da validade ou capacidade para traduzir os fenômenos, do plano conceitual, para a sua função no âmbito das práticas sociais. Nessa abordagem, as conversas e os textos são tratados como formas sociais de ação e não como representações de cognições pré-formadas. A categorização é tomada como construção de um duplo sentido: Construções culturais que são disponíveis para dar sentido a experiência; e construções situadas, utilizadas para a consecução de ações (persuasão, culpabilização, negação, refutação, acusação etc.).

Nessa perspectiva, o processo de desfamiliarização, implica tanto entender que determinadas categorias foram socialmente construídas, como entender os usos a que se prestam nos processos dialógicos da comunicação.

\footnotetext{
${ }^{8} \mathrm{O}$ conceito de práticas discursivas remete aos momentos de ressignificações, de rupturas, de produção de sentidos, ou seja, corresponde aos momentos ativos do uso da linguagem, nos quais convivem, tanto a ordem como a diversidade. Além disso, pode ser entendida como linguagem em ação, isto é, as maneiras a partir das quais as pessoas produzem sentidos e se posicionam em relaçães sociais cotidianas. (SPINK MJP, MEDRADO B. Produção de sentido no cotidiano: uma abordagem teórico-metodológica para análises das práticas discursivas. In: SPINK MJP. (org). Práticas Discursivas e Produção de Sentido no Cotidiano: Aproximações teóricas e metodológicas. São Paulo, Cortez Editora, $2^{\mathrm{a}}$ ed. 2000)
} 


\subsection{O Percurso metodológico}

\subsubsection{Trabalho de campo e os procedimentos para a coleta dos dados}

Em MINAYO (1999) o campo, na pesquisa qualitativa, é o recorte feito pelo pesquisador em termos de espaço, representando uma realidade empírica a ser estudada a partir das concepções teóricas que fundamentam o objeto da investigação.

O trabalho de campo referente à presente investigação foi realizado na cidade de Natal, município do Rio Grande do Norte, durante os meses de julho e agosto de 2001.

A escolha de Natal para sediar o trabalho de campo foi motivada pelo fato do municipio se constituir o local em que desenvolvo as minhas atividades laborais como docente e como médica pediatra, e para a qual retornarei depois de concluído o doutorado.

Para o estudo foi planejada a realização de 10 a 15 entrevistas com mulheres que sofreram perdas perinatais. Este número foi, num primeiro momento, considerado satisfatório ao delineamento do quadro empírico da pesquisa.

A primeira estratégia de aproximação com essas mulheres deu-se através da localização das Declarações de Óbito - DO (anexo 1), disponíveis na Secretaria Municipal de Saúde de Natal, referentes ao período de janeiro a julho ( $1^{\underline{a}}$ semana) de 2001,

Diferentemente do previsto no projeto inicial, a seleção das mulheres para participar da pesquisa não levou em conta apenas as que sofreram perdas neonatais precoces (óbitos ocorridos nos primeiros sete dias de vida), mas, considerou também, 
aquelas cujas perdas corresponderam a óbitos fetais, de vinte e duas semanas ou mais de gestação.

A decisão de ampliar o foco da investigação às perdas fetais deu-se por ocasião do levantamento das D.O., quando se pode constatar que grande parte das mortes referia-se a natimortos, ou seja, a perdas fetais tardias, pressupondo, por conseguinte, maiores condições de viabilidade fetal, pelo menos do ponto de vida da idade gestacional.

Procedimentos adotados para a seleção das declarações de óbitos: Na ocasião foram identificadas e recolhidas 135 D.O. - fetal e não fetal - das quais foram obtidas cópias xerográficas. $\mathrm{O}$ passo seguinte consistiu em realizar o processo da avaliação das respectivas D.O., a partir do qual foram sendo estabelecidos alguns critérios para exclusão e seleção das declarações.

Critérios de exclusão das declarações de óbitos: Ausência do registro de endereço; Não registro da idade gestacional e do peso da criança - impossibilitando o reconhecimento do grau de maturidade fetal; procedência do interior do Estado, identificada posteriormente; a não localização da rua no mapa da cidade. Baseado nestes critérios setenta e sete declarações foram excluídas, restando, ao final, apenas cinqüenta e oito DO.

O contato com as cinqüenta e oito mulheres, identificadas nas Declarações, deu-se através da remessa, via motoboy, de cartas convidando-as a participar da entrevista (anexo 2). A carta indicava local, data e horário da realização da entrevista. Entre as cartas enviadas, vinte endereços ou os seus destinatários não foram localizados. Em relação às trinta e oito restante, quinze atenderam ao convite, portanto, esses casos foram auto-selecionados. 
As entrevistas foram marcadas para serem realizadas no Hospital de Pediatria da UFRN, devido a sua localização central, por ser um local muito conhecido e utilizado pela população, e pela facilidade do acesso aos ônibus oriundos de todos os bairros da cidade.

$\mathrm{Na}$ ocasião foram realizadas entrevistas com quinze mulheres com história de perda perinatal - sete das quais tiveram óbitos fetais e oito neonatais precoces. Todas as entrevistas foram realizadas pelo investigador principal.

As vantagens apresentadas por esse procedimento foram: 1) a possibilidade da checagem dos endereços; b) a facilidade do acesso ao maior número de mulheres identificadas através das D.O., c) a previsão imediata do alcance do universo de mulheres a ser entrevistado; d) menor custo financeiro; e) menor tempo para realizar o trabalho de campo. Por outro lado, os vieses decorrentes do procedimento adotado, relacionados à interferência da escolha do espaço institucional sobre o processo da entrevista e à relação entrevistador-entrevistado, deverão ser considerados no trabalho por ocasião da análise e interpretação das mesmas.

A viabilidade do trabalho de campo, no período de julho e agosto de 2001 , só foi possivel com a adoção dos critérios mencionados anteriormente.

No intuito de atingir um número de entrevistas considerado adequado, dentro do prazo estabelecido, foi traçada uma programação incluindo o agendamento de entrevistas diárias - 02 (duas) no turno da manhã e 02 (duas) no turno da tarde equivalentes às cinqüenta e oito cartas enviadas. Estimou-se a disponibilidade de aproximadamente 02 (duas) horas para cada entrevista. $\mathrm{O}$ agendamento estabelecido levou em conta a possibilidade de faltas por parte das candidatas à entrevista. Nessa 
hipótese foi permitido supor que pelo menos uma entrevista fosse realizada durante o dia.

Foi pensada também a possibilidade de implementação de uma segunda estratégia de abordagem às mães - incluindo a visita domiciliar, com a disponibilidade do dia e horário da sua conveniência - para o caso de não se atingir o número e a qualidade esperada das entrevistas. Não foi necessária a utilização dessa estratégia em virtude de ter-se considerado satisfatório o material coletado.

Por ocasião das entrevistas foi apresentada a proposta do estudo - analisada e aprovada pelo Comitê de Ética e Pesquisa da Faculdade de Saúde Pública em setembro de 2000 (anexo 3), foram feitos os esclarecimentos sobre o que se pretendia investigar, as possiveis repercussões favoráveis advindas do processo investigativo, a justificativa da escolha da entrevistada, a garantia do anonimato da entrevista e do sigilo sobre autoria das respostas surgidas no conjunto do trabalho. Por fim, foi solicitada a formalização da aceitação em participar da entrevista através da assinatura do Termo de Consentimento (anexo 4).

Só depois de cumpridos esses passos iniciais, as entrevistas foram realizadas. Todas as mães que compareceram à entrevista se comprometeram formalmente a participar do estudo. Não houve ressalvas quanto ao uso do gravador durante a realização das entrevistas.

\subsubsection{Recursos utilizados para o registro dos dados}

No intuito de apreender os termos geradores de sentido no discurso das mulheres entrevistadas a partir da situação da perda foi organizado um roteiro 
temático $^{9}$ (anexo 5), para a realização das entrevistas. Entretanto, vale dizer que o mencionado roteiro apenas serviu como guia para a formulação das questões, mas não para dirigir o discurso. As entrevistas foram conduzidas admitindo-se uma certa flexibilidade. Tal procedimento teve como conseqüência a produção de uma narrativa mais aberta, incluindo relatos de experiências em outros âmbitos da vivência da entrevistada - pessoais, familiares, sociais - fazendo com que novos temas pudessem ser inseridos durante a sua realização.

Intervenções do investigador foram procedidas nos momentos de introduzir assuntos, nos casos de divagações e de dúvidas da entrevistada, bem como nos momentos de ressaltar aspectos considerados relevantes no curso da entrevista. Tínhamos em mente as perguntas fundamentais a serem feitas relativamente à problemática de interesse e por isso não tivemos muita preocupação com a ordem das suas colocações. Assim, cada entrevista foi conduzida levando em conta a singularidade dos atores e o contexto interpessoal, interacional e relacional entrevistador-entrevistado.

As entrevistas tiveram uma duração média de 77 minutos - mínimo de 35 minutos e máximo de 180 minutos. Em algumas situações o encerramento da entrevista foi conduzido pela entrevistadora, por ter alcançado o "efeito de saturação" da mesma, ou seja, quando o discurso passava a ser repetitivo. Em outras situações, a suspensão da entrevista foi definida pela entrevistada.

Os depoimentos pessoais foram colhidos por meio de entrevistas gravadas. $\mathrm{O}$ gravador foi utilizado como instrumento técnico próprio visando "(....) anular ou,

\footnotetext{
${ }^{9} \mathrm{Tal}$ roteiro resultou do enxugamento de um extenso questionário, o qual foi apresentado por ocasião do Exame de Qualificação do Projeto de Tese. O mesmo foi modificado por sugestão da Banca Examinadora e a sua elaboração foi apoiada em informações recolhidas sobre o assunto de interesse da pesquisa.
} 
pelo menos, diminuir o possivel desvio trazido pela intermediação do pesquisador" (QUEIROZ 1991, p.3).

Outras fontes complementares de informação consistiram: a) Ficha da informante (em nosso caso a Declaração de Óbito), encerrando dados pessoais objetivos, como idade, nivel de instrução, ocupação e dados da história reprodutiva da mulher. Estes dados, quando não se apresentavam devidamente preenchidos eram complementados por ocasião da entrevista; b) Diário de campo, no qual se anotou, simultânea ou posteriormente, as "percepções, angústias, questionamentos e informações que não são obtidas através da utilização de outras técnicas" (MINAYO 1999), além de outras anotações baseadas em observações acerca das condições da entrevista - relações entre informante e pesquisador, impressões, emoções, atitudes, reações ocorridas durante a entrevista.

\subsubsection{A transcrição das entrevistas}

Nesse estudo, o trabalho de transcrição das entrevistas gravadas seguiu a recomendação feita por QUEIROZ (1991), para quem a transcrição consiste na:

“(...) reprodução num segundo exemplar, de um documento, em plena e total conformidade com a sua primeira forma, em total identidade, sem nada que o modifique (...). O termo encerra também, como significado intrinseco, a noção de que tal reprodução é efetuada com o fim específico da conservação dos mesmos em local onde fiquem bem preservados, porém onde possam também ser facilmente atingidos por quem deseje consultálos" (QUEIROZ 1991, p.86). 
Portanto, no presente estudo o texto escrito e obtido a partir da transcrição literal das entrevistas gravadas resultou no discurso produzido pelo entrevistador e entrevistado.

O processo de transcrição foi conduzido utilizando-se os seguintes passos: a) escuta da fita gravada com reprodução integral do texto em microcomputador, incluindo as palavras e frases repetidas ou incompletas, e a alusão aos momentos de choro ou outras formas de manifestação da emoção; b) terminada a transcrição, foi retomada a escuta da gravação, acompanhada da leitura do texto escrito, efetuando-se as correções, complementações etc.; c) num exercício de memória procurou-se recordar e refazer o percurso da entrevista, para a devida complementação com informações do próprio entrevistador e com o auxílio do caderno de campo. Com esse procedimento obteve-se a forma narrativa final do texto conduzida pelo investigador.

Em seguida, o tratamento do material obtido das entrevistas requereu alguns cuidados. Os cuidados iniciais, já mencionados, com a transcrição do texto, e, posteriormente, com a sua decomposição, sua fragmentação em seus elementos fundamentais, com a separação dos diversos componentes, com o seu recorte, visando à simplificação e a recondução do material contido nos discursos.

Não obstante todas as quinze entrevistas terem sido transcritas e tratadas de acordo com os procedimentos referidos anteriormente, decidimos por utilizar nesta tese apenas nove entrevistas, as quais foram intencionalmente escolhidas a partir de duas condições: a) a idade gestacional do concepto acima de vinte e sete semanas 
(equivalente a um peso fetal igual ou superior a 1000 gramas) e, b) a não inclusão de malformação congênita como causa de morte. ${ }^{10}$

O estabelecimento desse critério teve como pressuposto a possibilidade de um maior reconhecimento, por parte da mulher, sobre as circunstâncias em que ocorreu a morte e sobre o que poderia tê-la evitado. Nesse sentido, a aproximação e configuração do perfil das mulheres com base na restrição das duas características mencionadas atenderam mais prontamente aos objetivos da presente investigação.

\subsubsection{A análise dos dados: análise do discurso}

A análise, no sentido operacional do termo, consiste em recortar:

“(...) uma totalidade nas partes que a formam, que são então apreendidas na seqüencia apresentada em sua naturalidade para, num segundo momento, serem estabelecidas numa nova coordenação. Num e noutro momento, isto é na decomposição e na subseqüente recomposição, obedecese tanto quanto possível às relações existentes entre as partes" (QUEIROZ 1991, p.92).

Seguindo este enfoque traçamos os caminhos a serem percorridos com relação ao tratamento do material transcrito para a feitura do recorte dos temas que a nossa análise pressupunha.

10 Com base nesses critérios seis entrevistas foram excluídas: três delas por tratarem-se de perdas em que as idades dos conceptos estavam abaixo de vinte e sete semanas de gestação, com fetos pesando menos de 700 gramas, numa condição de prematuridade extrema e reduzida possibilidade de sobrevivência; e três por apresentarem malformações congênitas múltiplas graves, de antemão, incompativeis com a vida. As narrativas em que tais características estiveram presentes revelaram-se pouco elucidativas as questões postas nessa investigação. "No contexto das malformações congênitas o termo evitabilidade apresenta outro significado que difere das mortes ocorridas intraparto de crianças não malformadas". (LANGHOFF-ROOS $\mathrm{J}$ et al. Potentially avoidable perinatal deaths in Denmark and Sweden 1991. Acta Obstet Gynecol Scand, 75(9):820-825, 1996). 
Partindo do pressuposto de que uma entrevista encarada de forma isolada, e desacompanhada do exame das partes que a compõe, não constitui um fim em si mesmo, recorremos ao procedimento da análise de discurso, considerando-a como BLANCHET e GOTMAN (1992), ou seja, como uma operação essencial efetuada antes de se alcançar os resultados da pesquisa, e que resulta da produção de um locutor em qualquer situação de interlocução.

Assim, na busca por apreender o sentido do discurso e revelar os sistemas de representações por ele gerado é que a presente investigação foi conduzida, utilizando como instrumento metodológico a análise de conteúdo, numa aproximação com os modelos descritos por QUEIROZ (1991), BLANCHET e GOTMAN (1992), BARDIN (2000). ${ }^{11}$

Entretanto, as inspirações e contribuições logradas a partir das consultas feitas às publicações mencionadas - aprofundamento do significado do texto, desmembramento dos tópicos na análise e a comparação dos resultados da análise com as questões da pesquisa - não representaram imposição de modelos ou normas operacionais rígidas na condução da análise efetuada.

\footnotetext{
"Na abordagem feita por BLANCHET e GOTMAN (1992) a análise se efetua sobre o corpus, ou seja, sobre o conjunto dos discursos produzidos pelos entrevistadores e entrevistados. E o tratamento dado ao discurso, se apresenta como uma produção conduzida pelo entrevistador. Portanto, ela não é uma produção neutra. (BLANCHET A, GOTMAN A. Análise dos Discursos. In: A enquête e seus Métodos: a entrevista. [Tradução Greice Menezes]. Éditions Nathan: Paris, 1992). (Cópia xerografada). Segundo BARDIN (2000) o objeto da análise de conteúdo é a palavra, isto é, o aspecto individual e atual da linguagem. Para a autora, a análise de conteúdo procura conhecer aquilo que está por trás das palavras sobre as quais se debruça. É uma busca de outras realidades através das mensagens. (BARDIN L. Análise de Conteúdo. Lisboa/Portugal, Edições 70 LDA, 2000).
} 


\subsubsection{Plano de análise}

No presente estudo o procedimento de análise do material coletado envolveu dois planos: um plano descritivo e um plano interpretativo.

No plano descritivo fez-se o reconhecimento dos diferentes depoimentos produzidos pelas mulheres e as formas dos seus enunciados, atentando, na descrição da trajetória, para o relato da experiência e para a composição das narrativas dos fatos.

No plano interpretativo atentou-se para a tradução das narrativas, ou seja, tratou-se de interpretar conteúdos e construir significados, buscando dar inteligibilidade operativa ao discurso, promovendo a delimitação dos fenômenos objetivos (fatos) e produtos de elaboração subjetiva (na representação, na descrição e na explicação dos fatos) - atribuições de responsabilidades, atribuições causais, evitabilidade da morte, por exemplo.

\subsubsection{Análise do conteúdo das entrevistas}

A produção dos resultados foi obtida a partir dos seguintes passos:

1) Análise por entrevista: análise exploratória de cada depoimento. Inicialmente realizou-se a leitura das entrevistas uma a uma (enquete exploratória), e por mais de uma vez. Nesta fase exploratória dos dados procedeu-se a identificação e o ajuizamento do conteúdo do texto com vistas à demarcação de fragmentos do discurso portando significação - primeira unidade de recorte. A procura dos dados no conteúdo do texto foi orientada pelas questões de interesse da pesquisa. Durante o 
processo de busca pôde-se detectar, além do relato dos acontecimentos, outras formas de manifestação da narrativa - como mecanismos de reflexão e julgamento expressados pela informante. O processo inicial de recorte dos fragmentos do discurso consistiu no realce de trechos do discurso utilizando cores variadas, acompanhado por designações. Essa técnica permitiu visualizar e identificar diferentes conjuntos temáticos (temas e índices temáticos), presentes em cada entrevista. Posteriormente, partiu-se para a organização de uma matriz temática (anexo 6), composta pelos conjuntos temáticos identificados. O tratamento unitário por entrevista, realizado no sentido vertical, foi efetuado com todas as entrevistas, respeitando o jogo de cores estabelecido para representar os mencionados conjuntos temáticos. Nesse primeiro momento da análise manteve-se a linearidade do discurso. O processo exploratório inicial, o recorte por entrevista demarcando fragmentos, compondo temas e atitudes manifestada pelo entrevistado, não apenas esboçou a estrutura singular de cada depoimento, como facilitou a organização do passo seguinte.

2) Análise temática por entrevista: recortes dos depoimentos por tema.

De imediato, a visualização da estrutura de cada entrevista em sua forma fragmentada, decomposta em cores, conferiu ao texto um aspecto desordenado e caótico. Essa configuração, decorrente da organização interna do texto, foi inscrita na maneira como cada narrativa foi desenvolvida - no mais das vezes sem linearidade, com idas e vindas, matizada por entrecruzamentos de assuntos. Dentro desses moldes a organização temática foi executada da seguinte forma: a partir da identificação e seleção de temas relevantes para o trabalho, desenvolvida no processo anterior, procedeu-se aos recortes e agrupamentos de trechos do discurso pelo método de 
recortar/colar, definidos pela similaridade entre as cores - sem perder de vista a distinção entre descrição e interpretação (avaliações, reflexões, comparações, explicações, julgamentos, opiniões, etc). Os recortes efetuados foram inseridos num quadro unitário de análise por entrevista (anexo 7). Feito isso, partiu-se para a análise temática sobre o conjunto das entrevistas.

Como resultado desse procedimento - em que a unidade de recorte foi o tema ${ }^{12}$ - foi construída uma matriz de análise ${ }^{13}$ (anexo 8), pautada nos objetivos da pesquisa, contemplando questões demarcadas previamente ou a posteriori. A matriz de análise do presente estudo foi elaborada utilizando seis grupos ou rubricas temáticas, cada uma delas constituída pelos respectivos temas e as especificações correspondentes. Os grupos ou rubricas temáticas consistiram nos seguintes: a) identificação, contendo dados pessoais e sociodemográficos; b) informações sobre nascimento e a morte fetal ou neonatal precoce; c) explicação materna sobre a morte; d) estrutura e contexto familiar; e) antecedentes obstétricos, pessoais, ginecológicos; f) antecedentes familiares.

3) Análise das entrevistas: a busca dos denominadores comuns a todas as entrevistas.

Esta foi conduzida a partir de recortes realizados transversalmente em todo o corpus, ou seja, sobre o conjunto dos discursos produzidos e transcritos. Procedeu-se à compilação dos vários recortes temáticos das entrevistas numa matriz única de

\footnotetext{
${ }^{12}$ Os temas constituem o enquadramento estável da análise de todas as entrevistas. (BLANCHET e GOTMAN op. cit. 1992). (Cópia xerografada). A noção de tema, largamente utilizada em análise temática, é característica da análise de conteúdo. $O$ tema é a unidade de significação que se liberta naturalmente de um texto analisado segundo certos critérios relativos à teoria que serve de guia a leitura. Pode ser recortado em idéias constituintes, em enunciados e em proposições portadoras de significaçðes isoláveis. (BARDIN op. cit. 2000).
} 
análise para todas as entrevistas (anexo 9). A forma de recorte foi construída de maneira estável de uma entrevista para outra.

4) Construção interpretativa - Esse processo final de aplicação metodológica resultou na recomposição dos depoimentos e estabelecimento de uma síntese ao mesmo tempo horizontal e vertical dos temas. Isso permitiu a instituição de significados aos temas, integrando, a partir da superposição das narrativas, uma combinação de achados - objetivos/ subjetivos; particulares/gerais; descritivos/interpretativos - portadores de sentido, estabelecendo, como diz BARDIN (2000), uma correspondência entre o nível empírico e teórico.

\subsection{As particularidades do método e o contexto da pesquisa}

É importante frisar que as entrevistas foram desenvolvidas como situações relacionais, nas quais procurou-se preservar as mesmas condições para todas as entrevistas - espaço, disponibilidade, escuta, respeito, etc. Contudo, esse modo de abordar não implicou anulação de diferenças entre interlocutores, sendo o conteúdo orientado por um contexto temático de natureza argumentativa configurado no processo da realização da entrevista.

A problematização intrínseca à situação relacional da entrevista, com possíveis interferências sobre a captação dos dados, não foi deixada de lado. Assim, na perspectiva da presente investigação optou-se por substituir uma postura de suposta neutralidade por uma proposta de problematização, relativamente à situação da

13 A matriz de análise é um instrumento explicativo, que visa à produção dos resultados, diferentemente do guia da entrevista, que é um instrumento de exploração, que visa a produção dos dados. (BLANCHET e GOTMAN op. cit. 1992). 
entrevista, em cujo contexto considerou-se: a situação social, a representação institucional, a formação cultural e profissional da entrevistadora.

Além disso, enquanto uma produção inter-relacional entre sujeitos, procurou-se manter uma abertura à subjetividade da entrevistadora e da entrevistada, e não da sua negação - durante o processo da entrevista-, por acreditar que o compromisso com o conhecimento não implica a anulação das crenças e emoções do pesquisador.

Por fim, no intuito de preservar o anonimato das mulheres entrevistadas utilizaremos nomes fictícios para identificá-las. Ao longo do trabalho os mesmos nomes serão mantidos em todas as ocasiões em que forem chamadas as falas. $\mathrm{Na}$ mesma medida, no intuito de preservar as instituições escolhemos por designá-las utilizando letras do alfabeto.

\subsubsection{Motivação e expectativa das entrevistadas em participar do estudo}

No presente trabalho, essa é uma questão sobre a qual gostaríamos de traçar algumas considerações. $\mathrm{O}$ que motivou as mulheres desse estudo a participar da entrevista para a qual foram convidadas? Que fatores foram mobilizados no momento da interação de cada uma delas com o teor da carta recebida, convidando-a a tomar parte de uma pesquisa, cujo conteúdo não explicitava o assunto que seria tratado? No quê elas queriam ser ouvidas? O que determinou a sua atitude de dirigirse ao local, no dia e horário marcados por mim, para tratar de um assunto que, supostamente, ela desconhecia? O que ela esperava encontrar?

A única orientação apresentada no convite estava na frase:

"Informo (....) que a sua participação trará uma valiosa colaboração ao desenvolvimento dos trabalhos oferecidos por essa e por outras instituições de saúde" (Vide carta, anexa). 
É sobre isso que trataremos nesse tópico.

O roteiro temático que foi elaborado para realização das entrevistas não contemplava esse nivel de preocupação sobre a motivação e expectativas das mulheres para participar da pesquisa. Contudo, naturalmente, esses pontos foram introduzidos, passando a fazer parte da abordagem no início da conversa ou durante a sua realização.

Em algumas entrevistas em que o assunto foi introduzido no seu início não houve a gravação desse momento. Outras, no entanto, foram gravadas e ocorre-me agora poder resgatá-las.

Quando perguntada sobre o que tinha achado do convite, Íris respondeu que não havia entendido nada do que estava na carta. Eu expliquei então que a carta era um convite para ela participar de uma pesquisa, e ela me respondeu: "Isso ai eu entendi que é pra..." Foi então que eu expliquei o assunto e os passos por mim adotados para identificação e localização da candidata à entrevista. Após a leitura do Termo de Consentimento ela me pediu para esclarecer, no segundo parágrafo, o significado da expressão "proposta de ação". No texto, a expressão está inserida da seguinte forma:

"A história que a senhora vai nos contar diz respeito aos acontecimentos $e$ as experiências vividas por ocasião da sua gestação e parto, dos problemas relacionados à sua saúde e do seu filho nos primeiros dias de vida e em relação à morte da criança. Esta informação não apenas vai nos ajudar a entender melhor todos os problemas relatados pela senhora, como também vai permitir que possamos fazer algumas propostas de ação visando diminui-los ou amenizá-los". [Termo de Consentimento]

De alguma forma, achei interessante a pergunta de Íris. Para mim, o seu gesto em querer compreender melhor essa passagem do texto poderia, tanto se constituir 
num diferencial interessante da entrevistada, como numa pista para pensar o que poderia estar buscando esta mulher na entrevista? $O$ que estaria ela querendo resgatar?

Dalva demonstrou preocupação em participar da entrevista. Contudo, apesar da apreensão decidiu pelo enfrentamento da situação:

“Tive muito nervosa ontem... Porque a gente... É uma coisa que eu nunca participei. É a primeira vez, então eu não sabia nem o que responder. Ainda perguntei pra o meu esposo: - 'Nilson o que é que eu vou fazer?' Ele disse: 'Você vai, escuta e depois você responde.' Porque a gente fica né. É a primeira vez! A gente não..." [Dalva].

Liana comentou o recebimento da carta da seguinte forma:

“Ai eu li, reli... Fiquei assim, pensando, o que será? (....). Eu achei... Eu achava uma coisa, depois achava outra. (...). Pra mim era sobre a criança" [Liana].

Para algumas mulheres a participação na pesquisa foi motivada pela esperança de poder elucidar as causas da morte do filho.

Esse, por exemplo, foi o caso de Íris: "Eu assim, eu pensava que era pra falar sobre o menino, num sabe? Assim, eu pensei que você ia só dizer como foi que ele... Sobre a doen... Do quê que ele morreu".

Nessa mesma direção, Ivani também se pronunciou em relação à entrevista. A sua expectativa era poder informar-se sobre a causa da morte do filho, e esclarecer quem seria responsável pela doença que acarretou a morte. Para ela, de certa maneira, a entrevista funcionaria como o espaço em que se daria esse esclarecimento, o momento para solucionar uma possível dúvida, gerada a partir das informações obtidas dos profissionais de saúde, sobre os problemas do bebê ao nascer. 
"Eu senti um pouco nervosa. Entendeu? Porque realmente... Porque minha irmã dizendo assim... Porque minha irmã disse logo, 'Ah porque você... $O$ problema da doença do menino, num sei o quê... Mas tu num sois doente. Será que tu tais doente?' E ela pensa que é outa coisa grave né? E ela falou tombém... Que ele é adoador de sangue, num sabe? Esse moço ai é adoador de sangue, o Luiz né? [Referindo-se ao companheiro, pai da criança]. Ai ela foi disse, 'Seu Luiz tombém. Que seu Luiz dá sangue pros outos, como é que ele vai dá... (....). Como é que ele vai ter doença, doença assim?' Ai eu fiquei calada. Não respondi nem uma, nem duas. Eu digo, 'Mas eu vou.", [Ivani].

Cristina comentou com o companheiro sobre o convite:

"Eu só falei que uma médica tinha me convidado pra comparecer numa entrevista sobre pediat... que ela era uma médica de pediatria. Ai ele perguntou assim, 'É alguma coisa sobre o seu curso?' Porque eu tô fazendo o curso de enfermagem, eu disse 'Eu não sei meu filho. Eu não sei sobre o que é.' Ai ele fez, 'Então tá certo, você vai?' Eu disse 'Vou. Eu quero saber o que é.' Ai ele disse 'Então tá certo.' Mas ele... Pra mim não pensou que era alguma com relação ao parto" [Cristina].

Carmem, ao ser indagada sobre como recebeu o convite, quais foram as suas motivações e expectativas em relação ao mesmo comentou: “... Ai eu disse assim 'O que será que a Maternidade quer comigo? Eu vou lá saber.' Vim só por curiosidade mesmo. Pra saber o que era".

Percebe-se na fala da entrevistada uma primeira indistinção entre a pessoa que fez o convite e a instituição Maternidade. Uma segunda indistinção aparece na confusão feita entre Maternidade e Hospital de Pediatria (local em que foi feita a entrevista). Esta última confusão poderia ser considerada trivial, tendo em vista a contigüidade dos dois hospitais, porém, em relação à primeira coloca-se diante de mim uma indagação, o que estaria eu, de fato, representando para Carmem naquele momento? Não estaria eu sendo confundida com a instituição? Em princípio, não vejo essa possibilidade como improvável, levando em conta o caráter oficial do 
convite, o local de realização da entrevista e as credenciais da entrevistadora. A escolha metodológica de realizar as entrevistas no espaço institucional, não pertencente à mulher, ao meu ver, não passou ilesa. A importância desse fato não deve ser deixada de lado considerando a possibilidade da sua influência na condução da entrevista.

Em sua abordagem Neide se expressou da seguinte maneira:

“(....) Aí eu li, ai reli ai disse, - 'Não, não, aqui não tem nada a ver com um curso que eu fiz.' Foi no setor de Pediatria, mas se for pra mim tá voluntariamente... é... Eu tive que ler bastante pra interpretar aquele Departamento, assim sobre trabalho né? Ai eu cheguei a conseqüência - ' $F$. [marido], isso aqui não é... Eu tenho uma ligeira impressão que isso aqui é sobre a entrada do óbito do menino.' Porque ele nasceu... o que aconteceu... Fiquei assim né, analisando. Pode ser, pode não ser. Ai eu fiquei assim, 'Jamais, jamais, a Maternidade vai querer tocar nesses assuntos, ' comigo né?" [Neide].

Restringindo o foco do nosso olhar para a compreensão inicial de Neide de que o convite pudesse significar a possibilidade de um trabalho para ela, me indago sobre qual é a natureza dessa formulação, e sobre o que está nela contida. Aqui, de novo, a instituição é convocada, só que, de uma maneira diferente daquela apresentada na fala anterior. Sob essa ótica, procuro pensar sobre os aspectos da experiência de Neide que poderiam estar fazendo parte dessa enunciação, na qual ela associa o convite e a possibilidade da oferta de trabalho. Nesse particular, ocorre-me, como hipótese, que o apelo da instituição pudesse significar uma forma de reparar a perda sofrida por ela. Sem dúvida trata-se de uma abstração, mas o tom ressentido no final da fala de Neide também chamou a minha atenção para o aspecto mencionado.

Antes de começar a entrevista Maria comentou sobre o recebimento da carta e afirmando que inicialmente associou o convite à possibilidade de uma proposta de 
trabalho no hospital. Isso porque ela era enfermeira e já tinha feito estágio no Hospital de Pediatria. Aqui, mais uma vez, pode-se reconhecer o local da entrevista interferindo no contato com a entrevistada. Infelizmente, esse momento da entrevista não foi gravado.

\subsubsection{Alguns aspectos interacionais do método}

O efeito da entrevista sobre a entrevistada pode ser apontado como um outro aspecto não contemplado pelo roteiro temático, porém, incluído durante a captação da informação.

No presente estudo, o momento da entrevista foi considerado um espaço que possibilitou ao entrevistado estabelecer um olhar sobre a própria experiência, falar da sua dor, retomar a vivência de forma retrospectiva e com julgamento. $\mathrm{O}$ seu efeito para muitos foi representado pela liberação de pensamentos e sentimentos de alívio, algumas vezes assumindo um tom de confidência.

A razão pela qual resolvemos trazer esse tópico à superficie foi guiada pela necessidade de abrir um caminho diferente, no sentido de recuperar o que foi possibilitado pelo método, a partir da situação relacional estabelecida no decorrer da entrevista.

Ao lidar com os textos produzidos pôde-se evidenciar, nas palavras das mulheres entrevistadas, a importância atribuída ao ato de falar sobre a sua experiência.

Para Liana, a vivência da entrevista trouxe alivio à sua angústia: " $A h$ ! $U m$ desabafo que pra mim parece que tirou um peso assim, de cima de mim, por muitas 
coisas. (....). Falei. Falei coisa que eu não esperava falar. Foi um desabafo muito grande".

Também para Íris a entrevista teve uma conotação de desabafo e alívio:

"Eu me senti bem porque pelo menos eu desabafei. (....). Assim... porque... Porque a morte do meu bebê tá muito recente ainda, né? Ai é bom conversar porque pelo menos eu respiro bem. Me sinto melhor. E eu achei melhor essa entrevista. Achei bom" [Íris].

Depoimento como o de Carmem mostra bem a importância por ela atribuída à entrevista, tanto no que toca ao efeito sobre si mesma - alívio da sua dor - como no alcance da pesquisa, relativamente à possibilidade da sua aplicação, a partir do resgate da sua experiência:

“É.. O que ela representou pra mim, um pouco assim de alivio, e eu acho que essa entrevista significa que o meu caso vai servir pra muitas mães que, como acontecer eles vão prestar mais atenção, os médico, eu acho isso, que essa entrevista significa pra isso. Pra não acontecer o que aconteceu... como que aconteceu comigo não acontecer com as outras, pra os médico prestar mais atenção. Não ficar só fazendo Prova de Toque (....). Que só fazer Prova de Toque eles não vão adivinhar nada, que tá se passando por dentro. Eles não tem $R X$ pra vê como é que tá a nenê por dentro. Eu acho que eles tem sim de fazer a Prova de Toque, vê... viu que a mãe tá sofrendo muito chegar e saber que ela... que a mãe tá tendo sangramento, saber... eles perceber que a nenê tá defecando dentro da mãe, a mãe tá sofrendo, $e$ a mãe não passa de dois centímetros, eu acho que o médico devia fazer uma ultra-sonografia e vê como tá o nenê por dentro. Como é que tá a posição dele, como é que ele tá, se ele tá com o cordão enrolado... O cordão umbilical enrolado no pescoço ou não, não escutar o coraçãozinho dele. Acho que isso pra mim não significa. Devia significar isso". [Carmem]

A fala de Neide, por outro lado, deixa transparece um certo sentimento de desamparo - revelado no limite da sua ação e da evocação da graça divina - e, ao mesmo tempo, de acolhimento em relação a sua participação na pesquisa. Além 
disso, Neide vislumbra a possibilidade da pesquisa vir a se constituir como porta-voz da frustração sofrida.

“(....) Eu disse, :Jesus tu toma a direção. Eu não vou denunciar nada... Mas, chegou uma oportunidade sem que eu fosse a procurar. Não é que eu tô dizendo assim... Ai, ia ser um denunciamento, assim, diferente, delegacia, esse negócio. Mas ai chegou ao conhecimento que pode mudar alguma coisa aí, tá entendendo? Sem precisar de coisas, de imprensa, disso, daquilo, coisas de dentro de recipiente de trabalho mesmo" [Neide].

No trecho a seguir as aspirações de Neide com relação à entrevista parecem ter claramente encontrado um lugar, enquanto porta-voz da sua insatisfação, do seu abandono. Vejamos a opinião de Neide sobre a pesquisa:

"Porque isso já era pra ter ó... Há muito tempo. Há muito tempo. Uma pessoa especializada nesse termo ai mesmo. Porque a gente não tem que vê só o lado do profissionalismo não. Nós temos que vê o outro lado. (....). Mas, tem muitos acontecimentos que tem que ter..., que chegar a um conhecimento desse né. (....). Olhe, quando eu sai daqui eu me senti tão culpada, eu disse, 'Jesus, quantas mães vão perder seus filhos? Com a falta de atenção"' [Neide].

Perguntada sobre a menção de culpa feita por ela, respondeu:

“Assim, de que... De não ter denunciado. De não ter falado o que... no... Falado o que eu falei pra senhora. O que eu estou revelando hoje. No momento que eu sai de dentro da Maternidade, tá entendendo? Mas ai, mas ai eu pensava assim, no meu sub-inconsciente 'Isso vai dar tanto problema, vai dar tanto rolo, isso eu vou ter que ir à delegacia, eu vou ter que ir pra tantos lugares, eu vou deixar nas mãos de Deus.' Eu orei e tá aqui. Chegou o tempo, chegou a hora né" [Neide].

Na percepção configurada por Maria com relação à entrevista inclui-se, além da possibilidade de desabafo, a manifestação de frustração no tocante a expectativa construída inicialmente. Assim foi concebida a sua fala: 
"Tô achando, achando assim... uma... uma... Foi até uma forma... Até de desabafar. Que até então eu não tinha nem desabafado com ninguém, como eu tô fazendo aqui hoje. E, até eu pensava que era... Que a entrevista seria direcionada a uma coisa né, e foi direcionada à outra. Mas, a entrevista $\dot{e}$..." [Maria].

Para Maria, a importância da pesquisa está na possibilidade de mudanças nas instâncias da assistência à saúde - na atitude dos profissionais em relação ao paciente e na disponibilidade de escuta ao paciente. A problemática inserida no discurso da entrevistada transparece da seguinte forma:

"A pesquisa, eu acho que vai ajudar muitos profissionais a abrir um pouco mais a mente e escutar o outro, né. Porque a gente como profissional, a gente não vê o outro, né. (....). ... eu acho que os profissionais da área de saúde têm que ficar mais aberto a ouvir do que a mandar... dizer, 'você tem que fazer isso, você tem que fazer aquilo'. Tem que ouvir uma parte da história da pessoa (....). Então, eu acho que... O seu trabalho, vai servir bastante pra o profissional que lida com essas questões de risco, tanto materno, infantil, ou, seja lá qual risco for, e, ouvir, é o que a gente tá precisando, que o profissional aprenda a ouvir, né" [Maria].

Convém observar que sendo Maria uma profissional de saúde que passou pela experiência da perda, o curso da sua narrativa apresenta-se marcado por uma dupla incursão: a primeira, localizada no plano de quem está na posição de cuidar (enfermeira) e a segunda, no lugar de quem necessita ser cuidada (a paciente). 


\section{As mulheres com história de perda perinatal}

Neste capitulo introduziremos alguns temas que foram contemplados nas entrevistas a fim de situar as mulheres no contexto de suas particularidades e dinâmicas relacionais.

\subsection{Caracterização do grupo estudado}

As nove mulheres que fazem parte desta pesquisa tiveram como pontos em comum. a experiência da perda do filho em idade gestacional acima de vinte e sete semanas e a ausência de malformação congênita como causa da morte.

Os diferenciais distintivos, de natureza formal, identificado entre as nove mulheres selecionadas, estabeleceram uma tipologia inicial, contemplando alguns aspectos valorativos destacados a partir da idéia de risco. A composição apresentada a seguir foi obtida das Declarações de Óbito (DO), complementada pelos depoimentos orais.

Inicialmente fez-se o reconhecimento do tipo de perda sofrida pela mulher, se fetal (a partir de vinte e oito semanas de gestação) ou não fetal (neonatal precoce). Com base nesse diferencial cinco mulheres foram incluídas no primeiro tipo e quatro no segundo.

No rol das perdas fetais, a média dos pesos de nascimento, obtida a partir dos pesos informados dos natimortos foi de 2.846 gramas. Já os quatro bebês, falecidos após o nascimento apresentaram uma média de peso de 3.283 gramas. 
Quanto ao tipo de parto realizado, cinco mulheres tiveram parto cesáreo e quatro tiveram parto vaginal. Seis dos partos aconteceram em serviço universitário, considerado de referência. Sete óbitos ocorreram no serviço mencionado em função do encaminhamento de um neonato, nascido em outro hospital, para internação na UTI daquele serviço.

Em relação ao número de gestações anteriores, três mulheres eram primigestas, duas eram secundigesta, uma era tercigesta e uma era quartigesta. No grupo de mulheres entrevistadas, apenas duas foram consideradas grandes multigestas - seis e catorze gestações. Entre as entrevistadas há relato de quatro abortos espontâneos e um provocado. Nenhuma delas tinha história de natimortalidade ou perda neonatal anterior.

Com respeito à idade das entrevistadas estas foram bem diversificadas. Em quatro mulheres as idades estavam compreendidas entre dezoito e vinte e seis anos; em três as idades foram localizadas entre trinta e quatro e trinta e seis anos; em três as idades corresponderam a trinta e sete, trinta e nove e quarenta e um anos respectivamente.

Quanto ao nivel de escolaridade das entrevistadas apenas uma tinha nivel superior, era enfermeira. Outra não tinha nenhum grau de instrução, não sabia ler nem escrever, segundo a sua informação. Uma tinha o segundo grau completo. As demais fizeram até o primeiro grau apenas.

Em relação ao estado civil das entrevistadas, oito conviviam com o companheiro, três das quais tinham as suas relações conjugais legalizadas. Uma delas era casada, mas estava separada do marido por ocasião da entrevista. 
Entre as nove mulheres entrevistadas apenas uma não teve acompanhamento pré-natal, todas as outras foram acompanhadas regularmente durante a gravidez. Por fim, nenhuma das nove mulheres teve gravidez múltipla e todos os partos foram hospitalares.

O registro dos dados sociais, demográficos e da história reprodutiva feminina, de maneira individualizada e sintética, pode ser visualizado no quadro 2 .

Quadro 2 - Síntese das características sociais, demográficas e reprodutivas das mulheres do estudo.

\begin{tabular}{|c|c|c|c|c|c|c|c|c|c|}
\hline \multirow{3}{*}{ Descriç̃o } & \multicolumn{9}{|c|}{ Identificaçũo } \\
\hline & \multicolumn{4}{|c|}{ Perdas neonatais } & \multicolumn{5}{|c|}{ Perdas fetais } \\
\hline & İris & Ivani & Carmem & Cristina & Neide & Dalva & Liana & Franca & Maria \\
\hline Idade (anos) & 19 & 41 & 22 & 22 & 26 & 34 & 36 & 39 & 37 \\
\hline Ocupacio & Do lar & Do lar & Doméstica & Do lar & $\begin{array}{l}\text { Assistente } \\
\text { de limpeza }\end{array}$ & Do lar & Do lar & $\begin{array}{c}\text { Auxiliar } \\
\text { de } \\
\text { nutricão }\end{array}$ & Enfermeira \\
\hline Estado civil & Casada' & Casada' & Casada' & Casada' & Casada $^{3}$ & Casada ${ }^{3}$ & Casada & Casada' & Casada' \\
\hline Escolaridade & $4^{n}$ série & $\begin{array}{c}\text { Sem } \\
\text { instruçá }\end{array}$ & $5^{n}$ serie & $\begin{array}{c}\text { Sem } \\
\text { informacao }\end{array}$ & $\begin{array}{c}\text { Segundo } \\
\text { graul }\end{array}$ & $5^{\natural}$ sèrie & $6^{a}$ série & $\begin{array}{l}12 \mathrm{e} \\
\text { mais }\end{array}$ & $\begin{array}{l}12 \mathrm{e} \\
\text { mais }\end{array}$ \\
\hline $\begin{array}{l}\text { Assistência } \\
\text { Pré-natal }\end{array}$ & Sim & Sim & Sim & Sim & Sim & Sim & Na & Sim & Sim \\
\hline $\begin{array}{l}\text { Nascimento } \\
\text { e morte (mês) }\end{array}$ & Marco & Junho & Julho & Janeiro & Janeiro & Abril & Março & Janeiro & Janeiro \\
\hline $\begin{array}{l}\text { Duracion } \\
\text { da gestacino } \\
\text { (semanas) }\end{array}$ & $37-41$ & $37-41$ & $37-4 !$ & $37-41$ & $37-41$ & $37-41$ & $37-41$ & $37-41$ & $37-41$ \\
\hline $\begin{array}{l}\text { Peso so nascer } \\
\text { (grames) }\end{array}$ & 3.480 & 2.550 & 3.545 & 3.560 & 3.700 & 2.335 & 2.700 & 2.650 & - \\
\hline $\begin{array}{l}\text { Tipo } \\
\text { de Gravidex }\end{array}$ & Única & Única & Única & Única & Ünica & Única & Unica & Única & Única \\
\hline Tipo de parto & Cesareo & Vaginal & Cesareo & Cesareo & Vaginal & Vaginal & Cesáneo & Vaginal & Cesáreo \\
\hline $\begin{array}{l}\text { Local } \\
\text { da ocorrência }\end{array}$ & A & A & A & $E$ & A & A & A & A & G \\
\hline $\begin{array}{l}\text { Gestaçoes } \\
\text { anteriores }\end{array}$ & 01 & 13 & 00 & 00 & 01 & 00 & 05 & 02 & 03 \\
\hline Filhos vivos & 00 & 13 & 00 & $\infty$ & 00 & 00 & 05 & 01 & 02 \\
\hline Filhos mortos & 00 & 00 & $\infty$ & $\infty$ & 00 & 00 & 00 & 00 & 00 \\
\hline Abortos & 01 & 00 & 00 & 00 & 01 & 00 & 00 & 01 & 01 \\
\hline
\end{tabular}

2 Uniôo oficializada, separada

3 Uniæo oficializada. Reside com o companheiro.

4 Trabal ha como doméstica em casa de familia. 
Esses dados evidenciam a presença de algumas características que, do ponto de vista clínico-epidemiológico, são consideradas de risco ou de proteção à gravidez.

Nesse sentido, como variáveis consideradas de risco foram observadas: às idades acima de 35 anos de quatro mulheres; o nível de escolaridade, em que uma aparece como sem instrução e três como não tendo concluído o primeiro grau; o número de gestações anteriores, em que duas mulheres apresentam-se como grande multípara; e a história de quatro mulheres com perdas por abortamento.

Como características de proteção identifica-se o acompanhamento no pré-natal realizado por quase todas as mulheres; a duração da gestação e peso dos bebês ao nascer, apontando na direção da viabilidade fetal, onde apenas um bebê está incluído na categoria de baixo peso ao nascer; e, finalmente, todas as gestações serem de fetos únicos.

Numa complementação às informações apresentadas, interessa-nos inserir nesse momento o perfil das mortes fetais e neonatais precoce a partir das causas que lhes foram atribuidas nos registros das DO. Com esse propósito foi feita uma leitura direcionada, num único plano, percorrendo cada DO, na busca por referências diagnósticas que fossem similares ou correlatas. Nesse procedimento não nos ativemos à maneira de preenchimento adotada. A partir daí verificamos que, afora uma DO com registro de causa ignorada, as demais declarações (oito) mencionaram a anóxia como uma das causas atribuídas à morte. Anóxia por asfixia mecânica (duas com circular de cordão e uma com prolapso do cordão no momento do parto), anóxia com descolamento prematuro de placenta, anóxia associada à doença hipertensiva materna e a insuficiência placentária, anóxia por aspiração de mecônio, anóxia associada à doença infecciosa do concepto. 
Interessante notar que, mesmo sem ter sido guiada pela indicação da causa de óbito para efetuar a escolha das entrevistadas, coincidentemente, em todos os casos a anóxia esteve presente.

De acordo com a Classificação de Redutibilidade dos Óbitos Neonatais da Fundação SEADE (1996) (anexo 10), as causas mencionadas acima se encontram citadas na referida Classificação como óbitos evitáveis por adequado controle na gravidez, por adequada atenção ao parto, por diagnóstico e tratamento precoces.

Partindo dessas informações adicionais algumas perguntas nos vem a mente: 1) Se essa mulheres estavam sendo monitoradas no pré-natal, por que não foram detectados problemas em relação à sua saúde, ou do feto, durante a gestação? Como se pôde notar, algumas mulheres que participaram do estudo portavam características consideradas de risco. E, sendo assim, teoricamente estariam incluídas no denominado grupo de "gestantes de alto risco", o qual remeteria a necessidade de atendimento dentro de parâmetros diferenciados "de acordo com as suas necessidades especificas" (BRASIL 2001); 2) e para a parcela de mulheres não inseridas na classificação de risco, que aspectos estiveram implicados no desfecho da morte do filho? O que poderia ter tornado um percurso gestacional sem risco numa gestação ou parto arriscado?

MINAYO, ao prefaciar o livro de NOGUEIRA (1994), refere que no Brasil, os traumatismos ocorridos no parto, as complicações maternas que afetam o bebê, os partos distócicos, as hipóxias intra-uterinas e asfixia ao nascer estão em primeiro lugar como causa de morte perinatal, evidenciando a precária atenção no pré-natal.

Segundo SIQUEIRA e col. (1975), citado por SANTOS (1999), o pré-natal se apresenta como o momento apropriado para a prevenção da morbimortalidade 
perinatal, possibilitando não apenas o controle de patologias existentes como também a correção de carências nutricionais identificadas. Não obstante, em nossos meio, resultados satisfatórios ainda não foram adequadamente alcançados em razão de falhas na qualidade da assistência. Porém, sobre isso, SIQUEIRA (1994a) refere que a qualidade do acompanhamento pré-natal nada garante sem uma assistência ao parto de qualidade. Na mesma medida, uma boa assistência ao parto, sem um bom acompanhamento pré-natal, não é suficiente para garantir uma assistência adequada ao recém-nascido e a mãe.

\subsection{Relações sociais e familiares: uma breve configuração}

Não obstante a configuração apresentada no tópico anterior, cuja tônica da apresentação foi reduzida a alguns aspectos classificatórios objetivos da caracterização do individuo, relativamente à morte perinatal, resolvemos por nos debruçar, a partir de agora, na investigação acerca de quem são essas mulheres que perderam seus bebês, tentando situar a questão da perda numa história de vida particular. Neste sentido, o nosso olhar se volta para outros atributos constitutivos da condição de cada mulher na sua inserção social e familiar, nas suas relações interpessoais, na interação de fatores subjetivos e objetivos decorrentes da situação concreta do seu meio sociocultural e de experiência social ${ }^{14}$.

\footnotetext{
${ }^{14}$ Por experiência social designa-se as marcas produzidas nos sujeitos pela sua inserção em diferentes critérios de classificação social - condição que determina sua apreensão do mundo e as vicissitudes de sua trajetória existencial. (HEILBORN ML. Gênero, sexualidade e saúde. In: SILVA DPM. Saúde, Sexualidade e Reprodução: compartilhando responsabilidades. Rio de Janeiro: Universidade do Estado do Rio de Janeiro, 1996).
} 
Nesses termos, os recortes e reflexões que se seguem sintetizam, em linhas gerais, a nossa perspectiva de aproximação com as mulheres integrantes do presente estudo.

Íris, 19 anos, mora com o companheiro. Ambos dividem a casa onde moram com dois amigos do seu marido, os quais trabalham com ele no comércio de cds. Ela refere à dificuldade de morar com essas pessoas em sua casa: “'́ assim, porque a casa é muito pequena. É ruim quando tem outras pessoas morando junto com a gente. Fica mais dificil". A casa em que mora é alugada e fica localizada numa vila. A casa tem quatro dependências, "É uma sala, uma cozinha e um quarto. (....). O banheiro fica fora". Os amigos do marido, que coabitam a mesma casa, ajudam a dividir as despesas. Íris convive com o companheiro há três anos. Teve uma gravidez anterior, que abortou espontaneamente. Ela é natural do Acre. Estudou até a quarta série e trabalha no lar. Depende financeiramente do companheiro. Em Natal não mora ninguém da sua família de origem. Sua mãe vive em Rondônia. A família do companheiro reside em Natal. A sua cunhada é freqüentemente mencionada em sua narrativa como alguém presente nos momentos marcantes da sua história.

Ivani, 41 anos, é natural da Paraíba. Mora em Natal há aproximadamente seis anos. Antes de vir para a cidade morava no campo, onde trabalhava como agricultora. Convive há dois anos com o companheiro, porém, ele é casado e possui uma outra família. Ambos não são alfabetizados. Trabalha no lar. Depende financeiramente do companheiro. Em sua narrativa ela fala dos diversos parceiros que teve ao longo da sua vida. Teve catorze filhos vivos e nenhuma perda anterior. A sua primeira filha nasceu quando tinha quinze anos de idade. Tem dois netos dos 
filhos mais velhos. $E^{\prime}$ assim que ela relata esse aspecto da sua vida sexual, reprodutiva e relacional:

"É... É... Que eu saiba mesmo só tem, a primeira que é de um pai. Esse outo segundo e mais outo, e mais outo, que é de um pai só. Que é três de um pai só. E então depois foi de cada um, um pai. São... E esse agora que é desse dai. E... (...). Mas, a verdade é bom dizer. Eu tive outo, mas ninguém sabe que era... ele era o pai. Porque tava tudo encoberto... Entendeu? (....). Não pensei antes. Fiquei desse jeito, nessa danação de viver gostando de home. E os home véio tudo casado, só me dava mesmo filho". [Ivani]

Carmem, 22 anos, há um ano mora com o companheiro. Estudou até a quinta série e trabalha como empregada doméstica. Não refere gravidez anterior. Mora em casa cedida pela mãe. Os pais são separados.

Cristina, 22 anos, convive com o companheiro, da mesma idade que a sua, há dois anos. Não refere gestação anterior. Deixou o emprego de comerciaria quando estava grávida. Depende financeiramente do marido.

"É. depois que eu fiquei grávida eu saí do emprego. Pedi pra sair e fiquei em casa né, pra ficar só cuidando, só do bebê. Ai depois que eu tive o bebê, como hoje em dia tá muito dificil de se encontrar trabalho, eu tô só estudando, eu tô fazendo um curso de auxiliar de enfermagem, e tô em casa, cuidando de casa. (....). [Cristina]

Cristina tem pai, mãe e uma irmã mais nova do que ela. No momento da entrevista estava fazendo o curso de Auxiliar de Enfermagem. A decisão de fazer o curso foi após ter sofrido a perda.

“... eu já tinha vontade de fazer curso de enfermagem né, e depois, quando aconteceu isso, que eu vi como as enfermeiras estavam me tratando ai, foi aí que eu quis que... fazer mais ainda, com mais vontade o curso, né. Então, é como se eu quisesse ficar... Depois que aconteceu isso eu tivesse mais determinação pra fazer alguma coisa. Me sentisse com mais vontade. Com 
mais desejo de realizar aquilo. Como eu não consegui realizar o desejo de ser mãe eu transferi meu desejo pra outra coisa". [Cristina]

Neide, 26 anos, mora com o companheiro na casa da sogra. O marido trabalha como eletricista. Neide concluiu o segundo grau e trabalha como auxiliar de limpeza numa agência bancária. Teve uma gravidez anterior, que foi voluntariamente interrompida. A sua familia de origem é composta de pai, mãe e seis irmãos. Diz preocupar-se com a situação financeira e por isso jả realizou diversos cursos na busca por uma condição melhor.

“... e tô ai na batalha, e pretendo fazer mais e mais né, pra um dia ter um espaço melhor, né? A gente tem que ser humilde, começar de baixo, que a Biblia diz muito... não só o dizer do povo, mas ai a palavra de Deus confirma, 'Te esforça que eu te ajudarei', e não é parada que a gente vai conseguir, não é?". [Neide]

Dalva, 34 anos, é casada há um ano. Não refere gravidez anterior. Trabalha no lar e depende financeiramente do marido. Estudou até a quinta série. Vive com o marido que é ajudante de pedreiro. Tem mãe e oito irmãos. O pai abandonou a familia quando ela era criança. A mãe arranjou um outro parceiro que, segundo ela, ajudou a criar os nove filhos. Não te

Liana, 36 anos, é casada há vinte anos e separada do marido, um comerciário de 38 anos. Teve cinco gestações anteriores. As filhas, nascidas vivas, uma com vinte anos (já casada). Uma com quinze. Uma com catorze. Uma com doze. A mais nova ia completar dois anos ainda. A filha mais velha mora em sua própria casa, com o marido. Duas das suas filhas moram com a avó (a de doze e de quinze anos). Estão sob os seus cuidados a filha de catorze anos e a mais nova. Trabalha apenas em casa e depende financeiramente da ajuda do marido e da filha mais velha. 
Franca. 39 anos, mora com o companheiro e um filho de onze anos. Teve duas gestações anteriores, um abortamento espontâneo. Trabalha como auxiliar de nutrição em um hospital público da cidade: “Eu trabalho de segunda a sexta, de seis a meio dia, e dois plantão por mês, de doze horas". O marido é motorista de uma empresa de ônibus. Sobre a relação com o marido ela diz: "A gente vive bem, Graças a Deus. Apesar de ter a discussão de casal mesmo né".

Maria, 37 anos, é casada, mora com o marido e duas filhas. Teve três gestações anteriores, um abortamento espontâneo. É enfermeira e trabalha como plantonista num hospital localizado em uma cidade próxima de Natal. O marido é comerciante.

Mesmo reconhecendo a breve contextualização na qual se esboça alguns traços culturais e de arranjos das relações sociais e familiares das entrevistadas, é possível notar que a problemática de gênero ${ }^{15}$ se faz presente, em dimensões diversas, nas distintas visões apresentadas. Dessa maneira pode-se visualizar o caráter relacional impresso a noção de gênero: na construção cultural do espaço social que ocupam; no papel que assumem ante a condição de dependência econômica do marido; na conduta perante as atividades chamadas para si - uma certa naturalização inscrita à mulher no que toca ao trabalho doméstico, em especial o do próprio lar, e na atividade procriativa, como bem deixa transparecer a fala de Ivani. Certamente, o modelo representacional do comportamento da maior parte das mulheres que compõe o grupo em estudo encontra a sua base na cultura. Nessa direção, FARIA e NOBRE (1997) chamam atenção para o aspecto da divisão entre trabalho reprodutivo e

\footnotetext{
${ }^{15} \mathrm{O}$ uso do termo gênero expressa um sistema de relações que inclui sexo, mas que transcende a diferença biológica (OLINTO, M.T.A. - Reflexões sobre o uso do conceito de gênero e/ou sexo na epidemiologia: um exemplo de modelos hierarquisados de análise. Rev. Bras. Epidemiol. 1(2):161$169,1998)$. O conceito de gênero enfatiza a idéia de relação/tensão no campo das interaçôes entre masculino e feminino (CORRÊA, S. - Gênero: Reflexões conceituais, Pedagógicas e Estratégicas. S.O.S. Corpo: Recife, 1994, p. 10).
} 
produtivo. Assim, o papel masculino idealizado é o de responsável pela subsistência econômica da família, e a isso corresponde designar o trabalho do homem na produção. A atribuição do trabalho doméstico designa as mulheres para o trabalho na reprodução: ter filhos criá-los, cuidar da sobrevivência de todos no cotidiano. Para a mulher, em geral o trabalho realizado fora de casa é considerado como uma extensão do seu papel de mãe. Dessa forma têm-se as atividades consideradas tipicamente femininas como serviço doméstico, professoras, enfermeiras, assistentes sociais.

\subsection{Maternidade: desejo e expectativa}

A introdução da temática da maternidade no contexto da morte perinatal não pode ser deixada de lado, face da sua vinculação com os fenômenos da concepção, gestação, nascimento e a perda do filho. Um acontecimento nada peculiar, por tratarse do rompimento em uma seqüência não esperada.

Tradicionalmente, o papel mais importante da mulher consiste em ser a disseminadora da cultura através da maternidade. O fato de ter útero e de amamentar significa não apenas que pode ter filhos, mas que é em grande medida responsável por eles (KITZINGER 1996).

A maternidade é traduzida como uma função social da mulher definida pela sua condição biológica. Os papéis sociais apropriados à condição feminina são inculcados pela sociedade desde a infância. $\mathrm{O}$ estilo da maternidade é, portanto, uma expressão da cultura e engloba um sistema de valores relacionados com o que é a mulher e também com o que é o filho, as atitudes para com ela variam de acordo com as classes sociais (KITZINGER 1996). 
Nesse sentido, o momento do nascimento, matizado pelo êxito ou fracasso desse acontecimento, apresenta-se relacionado com história de vida da mulher, a qual estabelece influência na sua relação com a gravidez e com o seu bebê. Pois, como diz KITZINGER (1996), não existe apenas um ideal de maternidade, existem várias formas sob o qual este se apresenta, das quais nenhuma é universalmente válida. Cada uma resulta da experiência empírica das mulheres de uma cultura especifica, adaptada ao sistema de valores da sociedade em que vivem.

Acerca do papel feminino e da função materna o trecho da fala de Íris é bem ilustrativo:

"Ai por isso que eu digo que home não sofre que nem uma mãe. Porque o home. o home só faz fazer e pronto. A mãe que carrega, a mãe que fica os nove meses grávida, a mãe que sente a dor, a mãe que vai ter, a mãe que vai cuidar. O home não faz nada, só faz dá a comida e pronto. Por isso que eu acho que a mãe sofre mais do que o pai. É, minha opinião é essa" (Íris).

Vale dizer que, a introdução dessa temática no contexto da perda não inclui a discussão sobre a questão da existência, ou não, do instintivo materno, nem do culto a nenhum modelo de maternidade. Nos atentaremos sim, a forma de representação da maternidade para as mulheres que sofreram a perda do filho e que participaram do presente estudo. Trata-se, portanto, de mostrar as diferentes feições impressas nas manifestações do sentimento da mulher quanto ao desejo, ou não, de engravidar num momento específico da sua existência, levando em conta a história pessoal e familiar e o contexto no qual estas mulheres se acham inseridas. 


\title{
4.3.1 As manifestações de uma gravidez desejada
}

İris (19), casada há três, secundigesta, fala da sua vontade de ser mãe desde quando era criança, do que pensa sobre a maternidade, e da sua alegria quando soube que estava grávida:

\begin{abstract}
"Sempre eu era louca pra ter um filho. Quando eu tinha dez anos eu virei pra minha mãe e disse bem assim, - 'Mãe, quando eu tiver grande, quando eu tiver dezesseis anos, eu vou querer engravidar e ter um filho gêmeo.' Ai minha mãe dizia, - 'Você fala isso porque você não sabe a dor de ter um filho. 'Eu dizia, - 'Ah mãe! Eu não quero saber. Eu quero... ' Ai ela disse, 'Pra criar... Não é tanto a dor! O problema é criar!' Eu dizia, - 'Não, criar é só trabalhar, dá de comer e pronto. E educar...' Ai ela dizia, - Não é assim não filha! As mães sofrem muito.' Ai quando eu completei dezesseis anos eu fiquei doida pra engravidar, mas não deu certo [Íris sofreu um aborto]. Ai quando foi depois... Agora já com dezoito anos... Ai que eu engravidei. Ai eu fiquei toda alegre". [Íris].
\end{abstract}

Carmem (22), primigesta, expressa o seu desejo de engravidar da seguinte forma: "Há muito eu tava querendo ficar grávida e eu não conseguia. Eu nunca usei anticoncepcional, e nenhum tipo de remédio". Antes, quando não tinha parceiro fixo, ela prevenia-se para evitar a gravidez. Informou que a sua gravidez foi motivada pelo desejo do marido dos sogros. Sobre isso, diz ela: “... os pais dele também queriam e cobravam isso de mim. (....). Ai eu disse, 'É, vamos!' E haja tentar, e haja tentar normalmente, normal, sem nenhum remédio, e nada de eu ficar grávida". Carmem refere ter procurado tratamento médico para engravidar. Sobre a gravidez ela fala: “Depois... assim, num piscar de olho, eu não tava nem esperando nem nada, ai a minha menstruação faltou. Uma coisa que nunca ela faltava. (....). Ai como de repente, no outro dia, fui buscar o exame deu positivo. Fiquei muito feliz". 
Cristina (22), casada há dois anos, primigesta, fala da sua dúvida com relação à vontade de engravidar, por se considerar muito jovem. Porém, menciona a transformação dos seus sentimentos no decorrer da sua gravidez:

"No começo eu ficava na dúvida, se eu queria mesmo esse filho, porque eu tava com quê..., com vinte anos. Eu ia completar vinte e um, ainda. Não, minto, eu tava com vinte e um. Eu ia completar vinte e dois. Então eu achava que tinha vindo numa hora errada. Mas depois que eu vi, que eu comecei a ler reportagem sobre criança né, comecei a comprar roupinha, isso e aquilo outro, eu comecei a gostar" [Cristina].

Dalva (34), casada há um ano, primeira gestação, expressou o seu desejo de ser mãe da seguinte maneira: "Tinha. Era meu sonho". Para ela, ser mãe significa:

"Criar... botar uma crian... criar uma criança, botar não. Criar uma criança é tudo na vida. Porque a criança veio ao mundo num sabe porquê. Então, o que a gente puder fazer por aquela criança a gente vai fazendo bom, num é fazer ruim. Dá carinho, dá amor, o que a gente puder fazer a gente faz. (....). Então, eu acho que aquilo ali é uma companhia na casa da gente né. A gente tá só, aquilo é uma companhia".[Dalva]

Maria (37), casada, grávida pela quinta vez, esperava um bebê do sexo masculino. Este iria ser o seu primeiro filho. Sobre isso ela fala: "O meu bebê era do sexo masculino. Tão esperado pe..., pela familia. Mas não foi possivel ele sobreviver".

\subsubsection{As manifestações de uma gravidez não planejada}

Neide (26), casada há dois anos, secundigesta, não teve a sua gestação planejada. O fato de morar com a sogra e de, tanto ela quanto o marido estarem 
desempregados na época. foram os motivos alegados para o seu não desejo de engravidar.

Ivani (41), convivendo com o último companheiro há dois anos, grande multípara, faz o seguinte comentário em relação a sua última gravidez: "Não queria mesmo! Queria não! (....)". Por outro lado, ela não utilizava nenhum método para evitar a gravidez. Essa era a décima quarta gestação de Ivani. Sobre a atitude em não prevenir a gravidez ela fala:

"Mas eu não tomava medicamento nenhum. (....). Não tomava não. Ai por isso que eu... Então... (....). Ai então aconteceu... (....). Não fazia nada não. O tempo que eu comecei usar camisinha... depois ele não gostou, nem eu tombém, que eu nunca tinha usado desse troço. Ai eu parei e pronto, acabou-se né. Aí... "[Ivani].

Liana (36), descobriu que estava grávida aos três meses de gestação e, quando estava no quarto mês separou-se do marido. Disse que a não foi uma gravidez planejada. Expressou o seu não desejo por ficar grávida da seguinte forma:

"Eu não quis a gravidez. Eu, no momento, eu tava assim... Eu toda vez que tomava o anticoncepcional, que eu recebia no posto, eu tinha muito enjôo. (...). Eu... dava muito dor no estômago. Eu ficava engoiando. Agora também não sei dizer se peguei tomando os comprimido ou foi... Ou se eu esqueci. (...). Eu acho que eu peguei tomando os comprimido. Possa ser que eu tenha esquecido um dia que eu não sei. Mas eu não me lembro. Sei que quando eu tomava eles eu sentia muito enjôo. E acostumei sentir os enjôos. Terminei tava grávida.". [Liana]

Tomou conhecimento que estava grávida no terceiro mês de gestação. Mencionou que foi uma gravidez indesejada até o momento em que descobriu que estava grávida de um bebê do sexo masculino. A partir desse instante os seus sentimentos e a sua atitude em relação à gravidez mudaram. Sobre isso ela fala: “(...). Eu não aceitava. Eu só vim aceitar a minha gravidez com uns sete meses, 
quando eu soube que era um menino". Liana era mãe de cinco meninas e esse seria o seu primeiro filho homem. Sobre a sua mudança de atitude em relação à gravidez ela diz:

“Quando eu soube que era um menino eu não queria mais... Eu não queria nem saber de poblema... (....). Fazia de tudo pra não... Pra não ter poblema. Passei a fumar muito pouco (...). Eu tava fumando uns quatro a cinco cigarros por dia. Eu comecei a querer ter as coisinhas dele. (....). Passei a me cuidar mais. (...). Ai eu passei a não olhar mais meus poblemas, deixar de lado, passei a me alimentar melhor. Eu pensava mais na minha sobrevivência. Eu achava que eu me alimentando direitinho, mesmo sem vontade, ele tava comendo. Se ele mexesse um pouquinho eu digo, 'Tá com fome.' Se eu tomasse um copo de leite era pensando nele. Tudo o que eu fazia era pensando nele... Mas, tarde! Acho que foi muito tarde!" [Liana].

No caso particular de Liana, que motivações e expectativas estavam implicadas na espera desse filho, capaz de interferir sobre o seu modo de proceder?

"Eu acho que nesse dia eu esqueci todos os poblemas que eu tinha. Todos. (...). ...eu tava tão feliz que eu nem imagino. (....). Eu fiquei muito feliz. Muito, muito. Foi... das poucas alegrias que eu tive, essa dai foi a maior. Um filho homem! Meu Deus! Eu ficava pensando, imaginando, 'Meu Deus! Eu ter um filho homem... 'Eu não acreditava" [Liana].

Vivenciando um momento difícil na sua relação conjugal, disse que a reação do marido quando soube que estava grávida foi a seguinte: “A reação dele? Hum. 'Te vira!' Ele... Ele nem aceitou". Contudo, no que toca a ambivalência dos seus sentimentos em relação à gravidez, e ao fato de estar esperando um filho do sexo masculino, Liana justifica:

\footnotetext{
"Não é porque eu não quisesse um filho. Eu queria muito. Tanto fazia ser menino como uma menina. Só que foi uma coisa que eu não planejei, e que eu já vinha passando por muita dificuldade e... eu ia tomar remédio, até mesmo pra abortar. E me ensinaram um remédio... no dia que eu fui tomar, na hora que eu ia tomar a criança se mexeu e eu não tomei". [Liana].
} 
Numa sintese ao que foi apresentado a partir dos depoimentos pôde-se evidenciar diferentes formas de atribuição de sentidos relacionados à gravidez e a maternidade - manifestadas na vontade ou não de ficar grávida, de ter ou de não ter filhos - variando da maior ou menor vontade, passando pela quase ausência de vontade, como expressado por Ivani. Todas essas formas de manifestação acham-se inseridas na história de vida particular de cada mulher analisada, e, sendo assim, tanto a gravidez quanto à maternidade, para cada uma delas, não existem como fatos isolados, mas dentro do seu espaço social e cultural.

\subsection{O cuidado}

\subsubsection{Situando a utilização do termo cuidado}

O termo cuidado designa: atenção; precaução, cautela (sentido de proteção de si mesma); Diligência, desvelo, zelo (que pode ser remetido ao outro, o movimento de busca de proteção para si e para o outro - Ex: a demanda ao pré-natal); encargo, responsabilidade, conta (conotação de assumir ou designar cuidado a outrem, em confiança - Ex: familiar, instituição de saúde, profissionais de saúde); inquietação de espirito (por uma experiência anterior conhecida ou vivida: Ex: "Vem do bem que foi perdido". "Antes de ser alcançado"); Pessoa ou coisa que é objeto de desvelos (uma gravidez, por exemplo). O termo cuidado também pode advir de algo pensado, imaginado, meditado; algo que pode ser previsto, calculado, suposto. E que por isso merecedor de atenção, cuidado, cautela. ${ }^{16}$

\footnotetext{
${ }^{16}$ O significado termo cuidado foi obtido do Novo Dicionário Aurélio Século XXI (op. cit. FERREIRA 1999), porém, os adendos realizados são da nossa responsabilidade. Os adendos servem para dar a direção que estabelecemos a implicação do cuidado com relação ao nosso estudo.
} 
O cuidado de si é norteado por saberes e práticas, e mediado pelo aspecto subjetivo, inconsciente da relação de si para consigo e para com o outro. O si para consigo vem da relação primordial com o outro: Mãe-bebê; mãe-pai-bebê, que compõe as relações familiares.

Portanto, a noção de cuidado aqui introduzida acha-se apoiada no discurso da mulher sobre a sua concepção e gravidez e na percepção da assistência recebida durante a gravidez e no parto.

Ao olhar para a concepção nos ateremos a observar como esta foi recebida pela mulher e pelo parceiro. No que toca a gestação o nosso olhar recairá sobre a vivência da gravidez e o surgimento de intercorrências. Ao falarmos sobre a assistência levaremos em conta a percepção da mulher sobre a atenção recebida pelo serviço de saúde (instituição e profissionais de saúde).

Através dos relatos que se seguem, descobriremos o que há em comum e no que difere os discurso das mulheres com relação a opiniões, condutas e expectativas relativamente à gravidez e ao parto. Nas histórias de cada qual perpassaremos sobre as estruturas, os valores, usos e costumes que faz das narrativas apresentadas a história da mulher.

\subsubsection{Percepção da gravidez: o olhar sobre a concepção e gestação}

A gravidez é uma situação que envolve não apenas a vida da mulher, mas também do seu companheiro e do meio social e relacional em que vive. 


\subsubsection{Concepção}

Para Íris e Neide a concepção foi percebida de maneira bem diferente. Em suas narrativas pode-se notar a grande diversidade de representações sobre esse momento peculiar do processo reprodutivo feminino.

Íris atribui a sua concepção ao seu desejo de engravidar e refere ter sentido o momento em que ficou grávida.

"E quando eu engravidei dele, quando eu me levantei eu virei pra ele e disse: 'Engravidei!' Ele disse: 'Engravidou como? Você é vidente pra saber que você engravidou?' Eu digo: 'Eu senti. Senti que eu engravidei.' Ai ele disse: 'Não Íris, você tá mentindo. ' Eu digo: 'Apois pode crer, vamos... 'Eu tinha menstruado no dia dezenove de junho, eu disse: 'Vamos vê se no dia dezenove de julho eu menstruo.' Ele disse: 'Você tá gozando com a minha cara. 'Comę̧ou a rir. Porque nós... Ó... Todas as vezes que eu engravidei, nós tava em fases, assim, dificil". [Íris]

Neide atribui a sua concepção a uma ação divina.

"Eu tinha displasia no útero... (....). [E] sempre vivia de circulo de oração, e nesse dia foi revelação de Deus. E eu fui pra lá muito enferma. A barriga era dessa altura. Dolorida, o tempo inteiro, eu não colocava nem o pé no chão. E lá foi... é coisa de Deus, é mistério... (....). E ele disse: 'E eis que hoje estou te curando jovem, de uma displasia no útero, e vou dar um fruto ao qual, que tu não podes ter.' Ai eu fiquei, 'Mas Jesus, um filho? Agora eu não queria não! (....). Mas ai fiquei, eu fiquei feliz, meu esposo ficou feliz, porque eu fui curada. (....). Ai eu procurei uma ginecologista pra fazer exames, ai ela passou uma ultra, foi a primeira ultra que eu fiz. Quando eu voltei, quando eu bati a ultra já tava com mais ou menos sete semanas. Já deu pra vê o embrião, né?" [Neide]

O reconhecimento da gravidez por parte de outras mulheres decorreu do atraso na menstruação. Assim foi com Dalva, Ivani, Carmem, Cristina, Liana, Franca, as quais tiveram a sua gestação confirmada através da realização de exames. 


\subsubsection{Gravidez}

\section{- Significado}

O significado da gravidez para as mulheres entrevistadas revelou-se de forma bastante diversificada e apresentando conotações distintas.

Para Liana, por exemplo, a vivência da gravidez foi cercada de problemas diversos, vinculados a sua condição social, econômica e familiar. Acerca disso ela se expressa:

“A minha gravidez... Eu fui muito doente na minha gravidez, pelos poblemas, que eu tava enfrentando, e pela dificuldade... (....). Eu passei uma situação financeira muito... Eu cheguei a passar muita fome na minha gravidez. Mas eu tinha vergonha de procurar a minha mãe. Eu tinha vergonha de ir na casa de minha filha. (....). E eu passei uma dificuldade muito grande porque ele tava com outra. É.. Não ligava... Eu sofri muito. Mas calada. (...). Foi na época que a minha filha começou dar trabalho. Tava com uns quatro mês de gravidez. ". [Liana]

Outra dificuldade. transcorrida no campo relacional, mencionada por Liana, e que também foi citada por Carmem, refere-se ao sentimento de aversão ao marido, ocorrido durante o período em que estiveram grávidas.

Ao falar sobre o assunto Carmem o faz da seguinte forma:

“... ele disse que depois que eu fiquei grávida eu fiquei fria pra ele. Num ligava pra ele, não dava atenção pra ele, num ligava pra nada. Eu... parece que eu fazia de... Fazia questão mesmo de ficar mais no trabalho do que em casa. Num suportava ficar em casa. (....). Ele reclamava muito disso. Que eu não tava mais ligando pra ele. Aí ele bebia muito. (....). Parecia que eu não suportava nada que ele fazia. Tudo no mundo... Um motivinho bem pequenininho eu já tava brigando com ele, já tava discutindo com ele. Às vezes eu mesmo me sentava e perguntava por que eu tava desse jeito. (....). Eu falei com meu pai. Meu pai disse que era normal mesmo, que eu tivesse paciência, que ele também passou por isso. 'Que eu tô tendo a paciência do mundo, num vejo a hora dessa menina nascer', ele dizia isso. [Carmem]. 
Maior susceptibilidade para ressentimentos e predisposição ao choro durante a gravidez foi percebida por Íris. Ela estabelece relação do seu estado de gravidez a uma certa fragilidade, infantilização e necessidade de proteção:

"Ele me fazia raiva toda hora, todo instante. Ai a mãe dele brigava com ele. dizia que não podia... Não podia me fazer raiva que eu não podia me emocionar, porque prejudicava o bebê. (....). Mas é porque quando a pessoa tá grávida a pessoa é mais insensivel (sic). Qualquer coisinha tá chorando. Se a pessoa dá um grito você já se sente mal. E desse jeito engravidar, a pessoa parece uma criança. Não pode brigar que já começa a chorar. (...), assim é uma pessoa grávida. (....). É. Desse jeito eu me sentia. Se uma pessoa falasse alto comigo, gritasse comigo. Eu já achava ruim. Ficava chorando. Dizia que queria tá junto da minha mãe, porque esses pessoal era tudo chato. (....). Quando a gente tava discutindo, eu começava a chorar e dizia que queria ir pro Acre, que queria tá perto da minha mãe. Aí ele ficava só calado". [Íris]

Segundo MARTINS e col. (1998) a regressão é uma característica dessa fase.

As demais entrevistadas referiram a inexistência de problemas durante a gravidez.

\section{- Intercorrências}

Contudo, em algumas narrativas foram apontadas intercorrências no curso da gestação. Dada a relevância desse aspecto no processo da gestação, decidimos por levar em conta o seu registro. Vejamos como estes se apresentaram no discurso:

“A única doença que eu tive foi uma gripe. (...). Tive uma gripe munto forte. (....). Pronto. (....). Gripei de novo e fiquei tossindo que só de novo, mas não tomei remédio não. Ai pronto. Só isso que eu sei dizer". [Ivani]

Mais adiante Ivani mencionou que sentia muitas dores e que teve corrimento vaginal no período em que esteve grávida. Além disso, fez referência a uma queda 
sofrida quando estava no oitavo mês de gestação: "Ai eu não me lembro como foi que eu caí. Se eu cai e bati com a barriga no chão, e se eu cai assentada. (....). Ai depois da queda ai que eu fiquei sentindo mais dores. Entendeu?"

O relato de enjôos na gravidez foi relativamente comum entre as mulheres.

Infeç̧ão urinária foi mencionada por Carmem

Sangramento durante a gestação foi mencionado por Cristina, Dalva, Neide e Franca. $\mathrm{O}$ período do seu aparecimento, em relação à idade gestacional, e a intensidade do sangramento variaram entre as quatro mulheres. A presença dessa intercorrência foi narrada da seguinte maneira:

“(...). No primeiro mês, eu tive um sangramento, né. Eu não sabia que eu tava grávida. Ai começou..., comecei a ter enjôos. Então eu fiz um exame, aí deu positivo. Ai, na primeira..., na mesma semana que eu fiz o exame eu tive um sangramento. Então, eu me desesperei, o meu esposo também, né, ai foi que me indicaram $V$. doutora. Ai eu fui, ela passou uma ultra, disse que tava tudo normal, então não aconteceu mais nada. Foi uma gravidez ótima”. [Cristina]

"Agora no começo, eu tava com três mês, (....), eu sentia assim... como se fosse... como é que chama!? Um sangramento né. Dava aquele sangramento. Do primeiro mês até o terceiro mês dava aquele sangramento". [Dalva].

O aparecimento de sangramento no final da gravidez foi relatado por Neide e Franca.

Neide referiu sangramento, após haver tido um susto:

"Eu... Ai levantei fui ao banheiro. Quando chego ao banheiro ai eu tô sangrando muito. (....). ...faltava quinze dias, quinze dias pra já entrar em trabalho de parto, porque são dez dias antes e dez dias após, né isso? Com a contagem dos médicos". [Neide]. 
Franca mencionou sangramento quando estava no oitavo mês de gestação, tendo procurado o serviço de saúde:

"Eu fiz uma ultra-sonografia, mas o médico examinou e disse que tava tudo normal. Ai, continuando trabalhando né? (....). Eu pensei que podia ter sido um abor... Começo de aborto, né? (....). Não. Só foi... (....). Não era dia de ir na médica ai no outro dia eu fui no hospital mesmo. Eu liguei pra ela, ai ela disse. 'Vá lá no pronto... no hospital. $O$ médico que tiver de plantão lhe examina.' Aí eu fui, a médica de plantão me examinou, escutou. (....). No outro dia quando eu fui não tava mais não [referindo-se ao sangramento]. Tinha parado mais. Ai ela pediu essa ultra-sonografia. Ai eu fiz até lá. $O$ médico não deu o laudo, só fez só... (.... ). Ai ele disse a mim que tava tudo bem. que tava tudo normal. Escutou os batimentos cardiacos. Ai ele disse até que era um menino, que eu não sabia o sexo ainda. Ai..." [Franca].

Também fez parte do quadro de intercorrências citadas pelas mulheres a presença de hipertensão. Relatou hipertensão na gravidez Liana e Dalva.

"Eu descobri que eu tava com pressão alta agora a pouco tempo. (....). Não. Não me sentia bem não. Tinha muita dor de cabeça. Ansia de vômito. Eu sentia uma quentura, quentura direto. E a casa que eu moro era muito quente e dava muita dor de cabeça. O que eu sentia na minha gravidez chorava muito. Eu me aperreava muito" [Liana].

Faltando aproximadamente cinco dias para os nove meses Dalva disse ter tido um aumento da sua pressão sanguínea: “... minha pressão teve muito alta. Eu fui no PS da Maternidade C, a médica me examinou, examinou o bebê, disse que tava tudo normal".

Liana e Franca manifestaram terem sido acometidas de depressão durante a gravidez da seguinte forma:

"Eu fiquei numa depressão muito grande, quando eu tava grávida dele. Eu passei por uma... Eu num... Eu não saia. Eu vivia mais assim... (....). ...e não queria escutar falar de ninguém, ninguém. Até se chegasse uma colega 
ou um vizinho, eu recebia, mas já recebia com raiva. Meu sentimento era de raiva. Sem... Sem motivo. Sem motivo eu... Eu tinha raiva de tudo, tudo, até de um copo que eu visse sujo eu tinha raiva. Eu tinha raiva até quando eu tava penteando o cabelo da minha menina pequena que ela não deixava. Já me agitava. Eu fiquei muito nervosa..." [Liana].

“... às vezes eu ficava assim... mas, eu acho que era depressão mesmo. devido à gravidez né? Que às vezes a gente tem né? (....). É. Eu tinha medo assim, quando eu fosse ter. Se acont... Alguma coisa que acontecesse. Pudesse ser que eu morresse" [Franca].

\section{- Percepcão sobre a duração da gestacão}

Íris, Cristina, Franca e Dalva afirmaram que chegaram a completar os nove meses de gestação.

Já Carmem referiu “... todo mundo dizia assim, 'Carmem tá passando da hora de nascer.' Porque tinha os dez dias antes, dez dias depois... Eu não entendo muito disso porque foi minha primeira gravidez".

Já Ivani disse o seguinte:

"E nas minhas conta fazia nove mês no dia quinze. Num sei né, porque realmente... (...). Nas minhas conta ele ia fazer nove mês no dia quinze. Entendeu? Mas nasceu no dia cinco de junho. Faltava... realmente faltava dez dias né, pra completar os nove?" [Ivani]

Anotações feitas em seu cartão da gestante constava que a data provável do parto seria o dia vinte e cinco de junho.

A duração da gestação Liana foi: "Oito meses". E a de Maria: "Trinta e oito semanas e cinco dias". 


\section{- Percepcão dos movimentos fetais}

O início da percepção dos movimentos fetais pela gestante varia de pessoa para pessoa. De uma maneira geral, na primeira gravidez a percepção dos movimentos fetais ocorre com aproximadamente quatro meses e meio. Às vezes, no entanto, os movimentos fetais não são percebidos ou são pouco percebidos. Situações de estresse da mulher também podem diminuir os movimentos sem que represente problemas para o feto. No caso em que se perceba diminuição recomenda-se a monitoração das condições do bebê. (MARQUES e DUARTE, 1998).

É importante ressaltar que a percepção dos movimentos fetais, além do aspecto objetivo do movimento do feto intra-útero, peculiar em todas as gestações, apresentase permeado de uma enorme carga de subjetividade. Trata-se de uma sensação singular, de fundamental importância à comunicação entre mãe, pai e filho, e que sinaliza muitas vezes a necessidade e a demanda por uma maior ou menor atenção do feto.

A percepção dos movimentos do feto, por parte das mulheres entrevistadas foi bem diversificada:

Para Íris,

"Ele chutava sabe, chutava tudo, desde do primeiro... Ele começou a mexer com... Eu ia fazer três meses quando ele começou a mexer. Dai ele mexia direto, toda hora, tuco, tuco tuco. Ai ele [o marido] dizia: 'Não, que não precisa você bater ultra porque o menino é sadio, porque ele só veve (sic) pulando dentro da sua barriga.' Eu digo: 'Não, mas eu quero saber."' [Íris].

Carmem, porém disse que: "A nenê não mexia muito, ela era muito quietinha. Ela só começou a mexer depois dos cinco meses" [Carmem]. 
Cristina começou a perceber os movimentos fetais entre quatro e cinco meses de gestação.

"Quatro pra cinco meses eu comecei a sentir uns empurrãozinho na barriga. Ai com..., de sete pra completar oito ele se mexia muito, muito, aqui em cima. E, ai eu perguntava a ela se era normal e ela dizia que era né, porque ele era um menino agitado. (....). Ele se mexia demais. Se virava muito. Me incomodava a noite. Eu não conseguia dormir, por causa que ele se mexendo" [Cristina]

A percepção, ou a não percepção, dos movimentos fetais, muitas vezes, é o que instiga a gestante a demanda por cuidado. Esse foi o motivo justificado por algumas das entrevistadas para a procura do serviço de saúde.

Ivani refere que algumas vezes não sentia o seu filho mexer. Por esse motivo procurou o serviço de saúde, porém foi tranqüilizada pelo médico.

Neide, ao falar sobre os movimentos do seu bebê afirma, convictamente, que "Sentia demais" no início da gravidez. Essa segurança, no entanto não parece manter-se no final da gestação, quando ela se expressa:

“Agora, quando foi assim, já se aproximando, eu não sei se era porque ele era grande pra minha placenta, então ele..., ele..., ele..., se ele se movesse, ele se sentia alguma coisa, que tava muito apertado né? E como ele já tava em posição querendo... (....). ... ele parou de se... mas eu sentia ele mexer aos poucos." [Neide].

Como explicação para uma possivel redução dos movimentos fetais Neide estabelece como representação à desproporção entre o seu espaço uterino e o tamanho do feto. Quando perguntada até quando ela sentiu o bebê mexer ela falou: "Uns dois dias antes. É assim que... É porque...". 
A dúvida com relação à percepção dos movimentos do feto no final da gestação também foi posta por outras mulheres entrevistadas.

Dalva descreve a sua experiência da seguinte forma: "Senti. Mexia bastante". Perguntada sobre o momento em que não notou mais que ele estava mexendo ela respondeu: "Eu não... Eu não sei nem explicar como é... (Inaudível) porque ele mexia bas... mexia normal né. Mas quando tava dois dias já pra morrer deu uma diarréia...".

Franca disse ter percebido os movimentos fetais:

"É... Porque ele se mexia muito. Ai eu não sei... Eu não me lembro, se nesse periodo... Porque tinha vez que ele mexia, mexia e ficava quieto, nera? (....). Na, na quarta-feira que eu fui... Na quarta pra quinta na Ma... Vim pra Maternidade. (...). Ele tava se mexendo durante o dia, foi. (....). Hum. Durante todo... (....). Tava se mexendo, era. Tava" [Franca].

Liana também expressou dúvida com relação aos movimentos do feto e se pronunciou: "Sentia muito pouco ele mexer. (....). Muito pouco. Agora eu não sei se era a criança que se mexia ou era já contração de alguma coisa. Mas eu não... (....). Ele mexia muito pouco. Muito devagar, mas mexia". Em seu depoimento ela diz que notava diferença em relação às gestações anteriores: "Porque ele mexia muito pouco". (...) A gente sente a criança... Até essa, a penúltima, a menina mexia demais, parecia que tava boiando, era pra lá e pra cá”. Apesar dessa observação ela não procurou assistência pré-natal.

O depoimento de Maria expõe uma outra dinâmica à sua percepção, que inclui aspectos objetivos, como observar e divisar que algo diferente está ocorrendo relativamente aos movimentos fetais, e subjetivos, expressos através da negação da 
possibilidade de que algo de errado pudesse acontecer. A narrativa de Maria sobre essa questão assume a seguinte forma:

"Mexia, mexia até demais, que até eu reclamava bastante, que, o bebê mexia tanto que às vezes até incomodava. (....). Muitas vezes, no plantão eu me deitava um pedaço, pra vê se melhorava, parava mais de mexer. (....). Mas, até então não tinha..., não tinha perda de líquido, não tinha nada, perda de líquido, nem per..., nem ficava com edema, nem tinha pressão alta. A pressão sempre normal, sem problema nenhum" [Maria].

"Inclusive, quatro, três dias antes de diagnosticar que ele tinha realmente morrido - isso aconteceu na terça - eu fui no sábado na casa da minha mãe e minha mãe disse assim: 'Nossa! Tá mexendo tanto hoje.' Eu falei bem assim: 'Hoje tá demais. Hoje tá assim como nunca'. Ai pronto. Mexeu mesmo, mesmo, no sábado. Aí no domingo já mexeu menos. A atividade diminuiu. Aí na segunda-feira, como já tinha parado mesmo assim de mexer mais, ai eu falei assim: 'Não, tá acontecendo alguma coisa!' Ai eu fui pra médica, né. Ela pediu uma ultra-som né, e ela não conseguiu auscultar. (....). Ai disse: 'Você tá sentindo mexer? Ai eu disse: 'Tô'. Ai disse: 'Tá mesmo?' Aí eu disse 'Tô'. Mexia, mas aí, eu não sei se eu queria que mexesse realmente, ou se era aquelas contrações como se o feto já tinha parado, ou se era aquelas contrações do próprio organismo querendo expulsar, né. Mas eu sentia, a barriga ficava endurecida, as contrações não eram como era antes, aquelas contrações mais intensas, era diminuidas, umas contrações diminuidas". [Maria]. 


\section{A dimensão da perda perinatal}

A fim de ampliar a perspectiva compreensiva da nossa proposta decidimos por introduzir nesse capítulo a temática da morte situando-a historicamente, enquanto acontecimento natural e sociocultural.

Num segundo momento nos ateremos à atribuição de sentido dado à perda a partir do relato das mulheres - os sentimentos e a perspectiva de uma nova gravidez.

\subsection{Sobre a morte e o morrer: uma breve historiografia}

Segundo MARTINS (1983), uma contextualização sobre a morte e o morrer na sociedade ocidental deixa transparecer que na atualidade estes são temas encarados com receio e silêncio. Passou a ser tema proibido e deixou de ser cultuado a partir de um longo percurso histórico.

ARIÈS $(1981,1982)$, após quase duas décadas de pesquisa sobre o tema da morte, busca uma explicação para as atitudes perante a morte nas sociedades ocidentais, da Idade Média aos nossos dias. Na sua obra ele situa, em alguns períodos históricos distintos, as diferentes formas de lidar com morte. Assim, de acordo com o autor, no início da Idade Média havia uma aceitação da morte. A morte era encarada com simplicidade e existia uma socialização do homem com a morte. Na segunda metade do período medieval - período em que floresceu o estilo barroco (aproximadamente dos fins do séc. XVI aos meados do séc. XVIII), com sua atmosfera artística e cultural carregada de conflitos entre o espiritual e o temporal, entre o místico e o terreno - a morte passou a ser vista com maior dramaticidade e 
individualidade. O homem descobre a "morte de si mesmo", e a morte assume um caráter de morbidez. A partir da metade do século XVIII, com o Iluminismo, a morte passa a ser dramatizada e exaltada. Toma um sentido da "morte do outro", com significado de ruptura. A morte se revela como indesejável, mesmo admirada pela beleza que lhe dá romantismo. No século XIX a morte passa a ser acompanhada no leito do moribundo por ritos, manifestações de choros e dramaticidade influenciada pela religiosidade católica e protestante. Surge então o culto da saudade. No século $\mathrm{XX}$, com a industrialização e urbanização, as atitudes diante da morte sofreram novas transformações, principalmente a partir da 1950, com tendência ao desaparecimento dos sentimentos coletivos tradicionais. Trata-se da "morte invertida" ou seja, é a morte que se esconde e que é vergonhosa, o grande fracasso da humanidade.

Segundo MARTINS (1983), surge nessa fase a motivação da mentira, o desejo de ocultar ao doente a verdade sobre a morte iminente. Não se morre mais em casa no meio dos seus, mas, no hospital e sozinho. A morte passa a ser um fenômeno técnico, dos médicos e da equipe hospitalar, não mais da familia. Importa agora que se perceba o mínimo possível a morte ocorrida; manifestações de luto e emoções são condenadas e abolidas; não se tem mais direito de chorar a perda de entres queridos.

Com a medicalização completa da morte pela medicina o hospital passou a não ser apenas mais um lugar de grande saber médico, de observação, de ensino, mas tornou-se o lugar de concentração de serviços auxiliares (laboratórios farmacêuticos), aparelhos aperfeiçoados, dispendiosos e caros, que dão ao serviço um monopólio local. A morte no hospital é ao mesmo tempo, conseqüência do progresso das técnicas médicas de abrandamento do sofrimento, e da impossibilidade material de 
aplicá-las em casa, de acordo com os regulamentos atuais. O hospital já não é, pois, apenas um lugar onde se cura e onde se morre por causa de um fracasso terapêutico; é o lugar da morte normal, prevista e aceita pelo pessoal médico. Nessas condições, apareceu um novo modelo da morte medicalizada, a morte no hospital, um style of dying. A morte deixou de ser admitida como fenômeno natural, necessário passando a ser considerada um fracasso. Quando a morte chega, ela é considerada um acidente, um sinal de impotência ou de imperícia que é preciso esquecer. Ela não deve interromper a rotina hospitalar, mais frágil do que a de qualquer outro meio profissional. Nesse sentido, portanto, a morte foi preparada para conciliar um fenômeno acidental, por vezes inevitável, com a segurança moral do hospital (ARIÈS 1982).

Um estudo sobre a percepção da morte com profissionais de unidade de terapia intensiva, referido por POPIM e BARBIERI (1990), demonstra que estes, apesar de estarem lidando constantemente com situações que envolvem a morte preocupam-se mais com a técnica para recuperação e garantia de vida e, quando a morte ocorre, é encarada como fracasso profissional.

Portanto, no ambiente hospitalar, a sensação de onipotência convive de forma muito íntima e ambígua com a sensação de impotência dos profissionais de saúde ao lidarem com a morte em suas várias facetas (POPIM e BARBIERI 1990).

Ainda dentro desse prisma historiográfico, alguns aspectos interessantes relativamente à demografia histórica merecem ser abordados, em virtude da sua contribuição decisiva na introdução de uma nova temática da morte e na sua interferência sobre o modo de decifrar os estudos de mortalidade. Nesse sentido, uma "mortalidade de crise", foi significada por uma morte não esperada, repentina, e 
esta, por sua vez, não produzia os mesmos efeitos de uma "morte de tempo normal", pressentida e preparada pelo próprio indivíduo, pela família, parentes e vizinhos; a existência de uma desigualdade social ante a morte foi um outro aspecto da contribuição dos estudos demográficos - a morte dos ricos não é a mesma do pobre; há ainda a morte dos bebês, das crianças, dos adultos e dos idosos, da mulher e do homem, do servo e do escravo; a morte coletiva das epidemias, da fome, das guerras; a morte individual - precocemente ocorrida antes dos progressos da medicina, sanitários e farmacêuticos (MARTINS 1983).

\subsection{O sentimento materno em relação à experiência da perda perinatal}

Ao se levar em conta as mudanças próprias da gravidez e a sua repercussão sobre a mulher, o que pensar quando esta é interrompida bruscamente, em caso de aborto, por exemplo, ou pela surpreendente notícia de que o feto está morto? $\mathrm{Na}$ mesma medida, o que pensar da perda ocorrida no momento do nascimento, ou poucos dias depois, momentos em que um outro tipo de "perda" - provocada pela separação do filho do corpo da mãe, estaria em processo?

De acordo com MALDONADO (1982) op. cit. POPIM e BARBIERI (1990), “... a perda intra-útero é acompanhada de depressão e frustração (....)." (p.135). Quando a morte ocorre nas primeiras horas após o parto a mãe sente um vazio frustrante, sem possibilidades de ser preenchido no momento; trata-se de um vínculo bruscamente rompido. Se a ocorrência se der nos primeiros dias ou semanas a mãe experimenta a sensação de esperança e desesperança, culpa, depressão e percebe o fato como castigo principalmente se a criança apresentar algum tipo de malformação. 
Quando a mulher descobre que perdeu o bebê diz QUAYLE (1991), citada por MARTINS e col. (1998), “... existe um corte abrupto nesse processo de construção de identidade, com negação de seu papel social de mãe" (p.155). Além disso, referem MARTINS e col. (1998), quando o ciclo gravídico experimenta rupturas e perdas, desencadeia-se um processo de luto pelo filho idealizado e pelo filho real, ambos perdidos, o que pode provocar um período de crise emocional significativo, de dificil elaboração e superação.

A morte como perda, segundo KOVÁCS (1992), fala em primeiro lugar de um vínculo que se rompe de forma irreversível, sobretudo quando ocorre perda real e concreta. Nesta representação de morte estão envolvidas duas pessoas: uma que é perdida e a outra que lamenta esta falta, um pedaço de si que se foi. O outro é em parte internalizado nas memórias e lembranças, na situação de luto ${ }^{17}$ elaborado. No dizer da autora, a morte como perda pressupõe um sentimento, uma pessoa e um tempo. É a morte que envolve basicamente, a relação entre pessoas.

BADINTER (1985) em seu livro "O mito do amor materno" refere:

"Temos hoje a convicção profunda de que a morte de um filho deixa uma marca indelével no coração da mãe. Mesmo aquela que perde prematuramente o seu feto conserva a lembrança dessa morte quando desejada a criança" (p.87-88).

Porém, historicamente isso nem sempre foi assim. A mentalidade era inversa, refere LEBRUN ${ }^{18}$ citado por BADINTER (1985): "No plano humano, a morte da

\footnotetext{
17 "O processo de luto por definição é um conjunto de reações diante de uma perda" (KOVÁCS J. Morte e desenvolvimento humano. São Paulo, Casa do Psicólogo, 1992, p.151). As fases do luto proposta por BOWLBY (1998) consistem: a) fase de torpor; b) fase de descrença e tentativa de modificar o resultado; c) fase de desorganização e de reorganização. (BOWLBY J. Apego e perda: tristeza e depressão. v.3. $2^{\mathrm{a}}$ ed. São Paulo, Martins Fontes, 1998).

${ }^{18}$ LEBRUN F. Les hommes et la mort en Anjou aux XVII ${ }^{\mathrm{e}}$ e XVIII ${ }^{\mathrm{e}}$, siècles, Paris, 1971. Citado por BADINTER E. Um Amor conquistado: o mito do amor materno. $9^{\text {a }}$ ed. Rio de Janeiro, Nova Fronteira, 1985.
} 
criança é sentida como um acidente quase banal, que um nascimento posterior virá reparar" (p.88).

Esse atestado de indiferença em relação à morte da criança, que antecede o século XVII, decorria, segundo ARIÈS (1981), das condições demográficas da época. Sobre esse sentimento diante da morte diz o autor: "As pessoas não se podiam apegar muito a algo que era considerado uma perda eventual" (p.56-57). As crianças morriam em grande quantidade, não chegando a sair de uma espécie de anonimato. O sentimento de indiferença com relação a uma infância demasiado frágil, em que a possibilidade de perda era muito grande, no fundo não estava muito longe da insensibilidade das sociedades romanas e chinesas, que praticavam o abandono das crianças recém-nascidas.

Só a partir do final do século XVII, com as mudanças ocorridas no modelo de familia até então vigente - tornada, a partir de então, espaço de afeição entre cônjuges e entre pais e filhos - a família passou a se organizar em torno da criança dando-lhe maior importância. Em conseqüência, diz ARIÈS (1981): “... se tornou impossivel perdê-la, ou substituí-la sem uma enorme dor, que ela não pôde mais ser reproduzida muitas vezes, e que se tornou necessário limitar seu número para melhor cuidar dela. " (p.12).

Por sua indesejabilidade, inexorabilidade e irreversibilidade, a morte constitui um dos temas mais ricos de racionalizações, em todas as culturas (NOGUEIRA 1983).

Na presente investigação, a narrativa das mulheres acerca dos seus sentimentos diante da perda atualiza aspectos impressos nas diferentes formas de inserção social e familiar próprios de cada história de vida. 
Neste sentido, pudemos captar das narrativas, sentimentos de saudade, raiva, medo, pesar, tristeza, punição, desgosto, mágoa e culpa, independentemente do tipo de perda ocorrida, se fetal ou neonatal precoce.

Manifestação de saudade foi revelada por Íris, Carmem e Liana como podemos observar a seguir:

"Ah. pra mim foi muito ruim. Eu ainda não esqueci. É.. eu tenho as coisinhas dele tudinho, guardado lá em casa. (....). As outras coisinhas dele eu guardei tudo" [Íris].

"Às vezes, quando eu pego nas coisa da nenê eu choro, eu sinto uma falta. Na hora que eu vejo... pro berço eu sinto uma falta. Mas ai de tarde eu ficou dizendo assim: 'Pô! Eu de licença médica, eu acho que se eu tivesse com o meu nenê o que é que eu tava fazendo hoje?' Às vezes eu pego o lençol, faço um gestinho assim como tivesse com o nenê. 'Eu acho que eu tava passeando com ela no meio da rua, andando com ela, levava pra casa da vó. ' (....). Ai eu choro, depois eu passo, ai rezo muito pra o próximo não acontecer o que aconteceu, e pronto" [Carmem].

“(...). Eu acho que a dor de um filho é pior do que uma... outra perda. Por mais pequenininho que ele seja. E mais ainda porque eu não vi. Quer dizer, tem hora que eu não me culpo porque eu não quis vê. Talvez se eu tivesse visto, hoje eu tava até conformada. Eu olho todas as noites pra fotozinha dele. E fico imaginando. Não é a mesma coisa. Eu queria ter visto sem tá ali dentro, mas não vi. Mas foi opção minha de não vê" [Liana].

Sentimentos de tristeza, abandono e raiva, foram referidos por Cristina.

"Eu me senti triste. Me senti sozinha também, desprezada, não porque tava todo mundo me dando carinho, me confortando, mas eu me sentia só. $\dot{E}$ como se tivessem tirado uma parte do meu corpo e eu não podia fazer nada com relação aquilo. Eu fiquei triste. Me sentia só porque eu queria meu filho. e ele não tava ali comigo. (....). Me senti só, porque eu tava faltando a companhia do meu filho, que, algumas horas atrás ele tava dentro da minha barriga, tava me fazendo companhia. E senti..., assim, eu não queria que ninguém sentisse pena de mim. Eu tinha esse sentimento. Que eu não queria que ninguém viesse dizer, 'Ah eu tô...Eu sinto muita pena porque aconteceu isso... 'Eu não queria que ninguém chegasse pra mim e dissesse isso. Eu senti essas três coisas, eu senti raiva, porque eu tinha perdido ele, senti solidão e senti que ninguém tivesse pena de mim, chegasse pra dizer que tava com pena de mim" [Cristina]. 
Já Dalva expressou o seu sentimento em relação à perda como algo inesperado.

"É uma dorzinha compricada. Porque a gente não espera né? Passa nove mês... (....). Pra mim foi... Deus me perdoe, mas foi horrive. Porque a gente faz... Fazer tudo direitinho... A criança mexendo e tudo. E a gente na hora que vai ter uma criança... a noticia que tá morta. Acho que é um choque de uma mãe munto grande. Acho que não tem quem deseje isso pra ninguém. Porque todo mundo quer ter seu fio do lado né, com saúde. Eu não esperava isso não" [Dalva].

O sentimento de abandono manifestado por Neide, Cristina também aparece na comparação com outras mães que estão com os seus filhos. Ivani também estabelece essa comparação em um dos trechos da sua narrativa, mostrada mais adiante.

"Eu senti assim, uma reação assim, de que todo mundo tava saindo com os seus filhos e eu não ia sair. Eu ia ser uma das únicas... Porque eu creio que aquilo não po..., não aconteceria só comigo mas que, eu ia observar todas saindo com o filho e eu não, mas, até enquanto isso eu me conformei, porque só..." [Neide].

"Eu via as outras mães com seus filhos então eu me sentia sozinha, eu sentia assim, que todo mundo ia sentir pena de mim. Por causa que eu tinha perdido o bebê, porque ele tinha morrido. Então eu me senti chateada, porque eu tinha perdido ele, e as outras mães tinham seus bebês e eu não" [Cristina].

Em sua manifestação de pesar Maria inclui os sentimentos da sua família, particularmente das filhas:

"Pra mim realmente foi assim, um choque imenso. Mas pra minhas crianças foi maior, porque elas esperavam..., tinham uma expectativa muito grande, né. De um irmão, de um irmãozinho, um bebezinho. É tanto que elas, toda criança que elas viam, das minhas cunhadas que tiveram bebê há pouco tempo, elas ficam muito ansiosa: 'mainha quando é que você vai ter outro bebê? Quando é que você vai comprar um bebê pra gente?"' [Maria]. 
A idéia de punição transparece na fala de Íris, por ela ter reclamado de alguns incômodos quando estava grávida.

“... eu reclamava, quando eu ia dormir. Eu dizia: 'Ah meu Deus do céu é muito ruim a pessoa ficar com o barrigão porque só pode dormir de banda, de banda e de banda.' Só falava isso. Aí Zé disse: 'Você ainda quer engravidar de novo?' Eu dizia: 'Eu não.' Eu acho que Deus me castigou por isso, porque eu dizia que não queria mais engravidar" [Íris].

A ligação da culpa com a morte do outro é referida por KOVÁCS (1992) como um elemento que está muito presente no acontecimento da morte. Para a autora, este sentimento está relacionado com “...o pensamento mágico e onipotente infantil $e$ com os elementos de socialização que levam a desejos de morte, de tal forma que, se ocorre uma morte, é inevitável que a criança estabeleça uma relação entre esses desejos e a morte efetiva" [p. 4].

Racionalmente o adulto reconhece que não é assim, porém emocionalmente é freqüente a atribuição da culpa pela morte do outro. Outra manifestação incluindo a idéia de punição por parte de Íris foi trazida num outro ponto da sua narrativa, desta feita colocando-a sobre o marido. O marido estaria sendo punido por expressar a sua preferência por um filho do sexo masculino ao invés de feminino. No trecho escrito abaixo é possivel notar também a forte conotação de valores atribuídos à problemática de gênero.

"Ele dizia que queria porque queria que fosse um menino home. Porque não queria que fosse mulher, porque ele disse que mulher os machos... como é... vai fazer coisa feia com a filha dele e ele não ia gostar, num seio quê. Porque queria porque queria home porque fazia com as filha dos outo. Ai eu dizia: 'Você é muito gaiato. Você gosta de fazer coisa com as filhas dos outo e não gosta de ter sua filha né, pros outo fazer também.' Ai ele ficava calado. Ai quando eu tava chorando eu disse isso pra Maria eu disse: 'Maria será que Deus castigou, castigou Zé por causa que ele falava 
essas besteiras quando eu tava grávida, porque queria home, que era melhor home do que mulher, num sei o que? "'[Íris].

Por outro lado. também evidenciamos sentimento de alívio e ressentimento pela perda, mesmo que tocado por um certo sofrimento. A expressão desse sentimento expôs de forma ampliada outros aspectos da história de vida da mulher, deixando entrever relatos de abandono, desamparo e outras perdas.

Essa forma de representação dos sentimentos diante da perda do filho foi posta por Ivani da seguinte forma:

“Ai, Graças a Deus, Jesus fez essas obra pra mim, essa obra de caridade pra mim, que levou pra o céu. Pra mim foi uma maravia né, que eu digo, e sempre digo, e nem chorei tanto assim. Eu chorei mais do que eu dei, sabe? [para adoção]. Dos outos que eu dei pro pessoal... munto mais do que desse agora" [Ivani].

Ivani por si mesma trata de contextualizar a sua fala atribuindo julgamento a sua atitude:

“... pra mim foi uma maravia, porque num tá sofrendo aqui. E, do jeito que nasceu doente, que disseram que o problema dele ia ficar assim, que nem uma fraqueza no juizo, munta coisa... Que tinha que ter munto... tratamento munto séro, e assim... Foi umas benção que Deus fez." [Ivani].

Considero relevante refletir um pouco sobre o conteúdo da expressão de alívio e conformação destacados por Ivani.

“E eu nem sabia que o meu tava morto né. (....). Ai eu tava maginando, 'Meu Deus. as mães tudo com as suas crianças aí, e eu tô aqui maginando 
como é que tá o meu. E eu, no mesmo tempo, eu tô maginando de pegar e dá... (....). E vou pegar e dá minha criança e o pai não quer que eu dê. Mas no mesmo tempo ele também não comprou nada pro nascimento desse nenê.' (....). Eu senti as lágrimas descer. (....). E mais vendo as mães tudo com seus filhos ali, tudo naquele amor e tudo, cheio (Inaudivel)... de comprinhas, as coisinha tudo direitinho pros seus filhos. Ai fiquei maginando e pensando que ele [parceiro] não tinha nem vindo me avisitar na tarde, né. E nem tinha vindo até aquele momento lá, nem tinha ligado nem coisa nenhuma. (....). E deixa que Deus já tinha levado" [Ivani].

No seu discurso também parecem coexistir aspectos relacionados à sua condição de vida, da situação do aparente insegurança e incerteza cotidiana. Para Ivani, perder o filho para Deus pareceu ser menos doloroso do que delegar a outrem o direito a apropriar-se dele. Ivani em outros trechos de sua entrevista revela ser possuidora de uma condição de grande desamparo social.

\subsection{Dando sentido a perda}

Segundo SPINK e MENEGON (2000), dar sentido ao mundo é uma prática social que faz parte da nossa condição humana. Essa atividade é desenvolvida nas relações que compõe o nosso cotidiano, o qual, por sua vez, é atravessado por práticas discursivas construídas pela multiplicidade de vozes. As idéias com as quais convivemos, as categorias que usamos para expressá-las e os conceitos que buscamos formalizar são constituintes de domínios diversos (da religião, da arte, da filosofia. da ciência), de grupos que nos são mais próximos (familia, escola, comunidade, meio profissional, etc.) e da mídia em geral.

Segundo LEPARGNEUR (1987), a religião, muito mais do que a arte, é que devolve ao ser humano a serenidade diante da morte. 
No mundo cristão, as diferentes atitudes e comportamentos diante da morte podem ser explicados por elementos histórico-econômicos, sociais, ideológicos (NOVAES 1983). Segundo a autora, para crentes e católicos, as atitudes e comportamentos também dependem de quem morre e como morre.

Em nosso estudo, enquanto parte integrante do núcleo vivencial das mulheres com história de morte perinatal, a religiosidade emergiu como argumento utilizado para o enfrentamento da perda e busca do alívio para dor.

Da mesma maneira que foi mencionada por POPIM e BARBIERI (1990), “Essa religiosidade expressa-se através da verbalização de submissão a uma vontade divina, diante da qual cabe a aceitação" (p.138). Ao lado da submissão aos desígnios divinos aparecem, também, manifestações de “impotência diante do ocorrido".

As manifestações da religiosidade das mulheres tiveram os seguintes teores:

- Conforto e resignação na fala de Neide

"Deus me confortou, não sei porque, mas ele me confortou. (....). E eu vou ter um filho sim, porque isso aqui aconteceu porque Deus não permitiu assim, né. (....). Penso assim, se Deus não permi..." [Neide].

- Conforto, resignação e reparação na fala de Dalva

“Apesar que na hora do... a gente vai sentir o choque, que a criança tá morta, mas Deus dá o conforto. (....). Era toda a minha vida... Que meu sonho era ter uma criança né? Acho que todo casal sonha ter uma criança, sadio. Mas, tá na mão de Deus. (....). Ele sabe o que faz... A gente não sabe o que diz. Se ele viu que eu não merecia" [Dalva].

- Resignação e conformismo nas falas de Franca e Ivani 
"Deus sabe né? Eu acho que num... Deus sabe o... Num sei... Os mais velhos diz, né, 'Deus sabe o que faz, a gente não sabe o que diz' né? Eu não sei se foi a vontade de Deus que quis que eu não criasse meu filho, mas... Eu também já tenho um, não é?" [Franca].

"Deus sabe o que é que faz e a gente não sabe o que é que diz, no mesmo tempo. Ai Deus levou... Levou ele. Mas eu não sei como... Porque foi" [Ivani].

- Força de ânimo perante os homens e submissão à vontade divina foram expressões manifestadas por Cristina

"Mas. depois que eu perdi ele, eu fiquei com aquela garra, digamos assim. de eu conseguir as coisas e não perder mais pra ninguém, mais pra nada, só pra Deus mesmo" [Cristina].

\subsection{Perspectivas de uma nova gravidez}

BOWLBY (1998) observa que tanto o nascimento de um natimorto, como a morte de um recém-nascido, pode afetar os sentimentos de mulheres quanto à possibilidade de ter um novo filho.

Para FREITAS (2000) "A dor e a tristeza que sentem os enlutados são provocadas pela perda sofrida. No luto por morte de alguém querido, o individuo tem que conseguir retirar suas cargas libidinais, ou seja, seus afetos, das diversas representações intrapsíquicas do objeto perdido. Em razão da inércia psíquica, supõe esforço, sendo o trabalho do luto doloroso" (p.23).

Segundo a autora, "O sofrimento da perda pode estimular sublimações, que contribuem para a elaboração do luto. Há pessoas que, após um luto intenso tornam-se mais produtivas (....). Outras produzem verdadeiras obras de arte. São 
experiências prazerosas e representam uma forma de vencer as frustrações e o desprazer" (p.41)

Não obstante. segundo BROMBERG (1996) a atitude de recuperar o filho pode ser vivida como a substituição da morte por uma nova gravidez. Segundo a autora é freqüente a tentativa de ter um outro filho antes que o luto tenha sido elaborado.

FREITAS (2000), citando alguns autores, afirma que algumas mães ao tentar ter outro filho logo em seguida à perda, muitas vezes dão o mesmo nome do filho falecido à criança, numa tentativa de substituir o filho que morreu. Porém, como afirma BADINTER (1985), o fato de poder engendrar um outro, nove meses mais tarde, não anula a morte do precedente (p.88).

As motivações para ter ou não ter uma outra gravidez após a experiência da perda do filho são muitos diversificadas entre as mulheres entrevistadas. Na presente investigação a perspectiva de uma nova gravidez parece ancorar-se no sentimento de medo e desejo de resgate.

Íris falando sobre a perspectiva de uma nova gravidez diz que prefere logo uma gravidez para esquecer a dor sofrida pela perda do filho.

"Ai depois eu perdi. Pensava que eu não ia querer né, engravidar mais. Porque tem mulé que fica com trauma, não quer mais engravidar, com medo de o bebê nascer com o mesmo problema. Eu não, eu fui diferente. Eu já quero engravidar pra vê se eu esqueço a perda do outro. Ai por enquanto não dá por causa que é cesáreo, porque senão eu queria" [Íris].

O companheiro não partilha do mesmo desejo de Íris sobre uma nova gravidez. Ele vincula a possibilidade de outra gravidez à aquisição da casa própria. A necessidade de ambos, no que toca ao interesse de ter filhos, parece ser diferente. $\mathrm{O}$ que move o desejo de um e do outro? Talvez coubesse aqui uma discussão sobre a 
questão da maternidade $\mathrm{X}$ paternidade, porém não discorreremos sobre essa temática.

Nesse sentido ela se pronuncia:

“Assim... Eu disse pra ele que eu queria ter um agora. Porque pelo menos eu esquecia mais a dor do outo né? Ai ele disse: 'Não porque Iri... A gente tá... Você operou agora e não pode, pode abrir sua barriga. Você tem que esperar mais uns dias. ' Ai eu disse: 'Tá bom.' Ele disse: 'Depois que nós tiver na nossa casa ai você pode ter um filho. Mas a gente na casa dos outo é muito ruim "' [Íris].

Atitude de Ivani frente à possibilidade de uma nova gravidez coloca-se da seguinte maneira:

“.. a patroa da minha filha veio me perguntar se eu não tinha... Se eu ainda ia ter filho, né. A resposta que eu dei pra ela, que não sabia, só Deus é quem sabe. Porque realmente é... A gente faz o jeito de não ter, mas, no mesmo tempo, quando Deus quer não tem quem evite, né, no mesmo tempo. Eu mesmo penso assim né" [Ivani].

"E agora jả tô com medo. Pode acreditar.(...). Porque eu já tive relação. Ai eu tava dizendo a ele, 'Ói...' Eu tive relação com ele antes de quarenta dia. Foi com quarenta dia que eu tive, com esse. Mamãe nem sabe ainda. Mamãe tá... Se ela souber vai dar a mulinga comigo, porque ela não queria. Porque é... que nem eu tô dizendo, tô sentindo muitas dores ainda, entendeu? Eu não sei que é algum problema que eu tô sentindo, na vagina. Num sei o que é. Eu sei que eu tô sentindo muntas dores" [Ivani]

Carmem vincula a possibilidade de engravidar novamente a uma mudança de atitude do companheiro:

"Penso. Já conversei com ele. (....). Eu já falei com ele. Disse a ele que quando eu ficasse grávida de novo a gente ia fazer... E ai eu disse, ' $\dot{E}$, você quer ter outro filho, bom, vou ficar grávida de novo, mas você vai diminuir suas cachaça, vamos parar com essas briga, como no começo, que a gente brigava muito, e vamos tentar" [Carmem]. 
Neide relaciona a possibilidade de uma nova gravidez à estabilidade econômica e emocional, diz ela:

"Mas eu estou preparada. Ai, quando eu tiver na minha casa, ter mais outro. Eu tô pra isso né? (....). Espero que cada dia mais, daqui pra frente lutar pra quando for ter um filho, tá preparada psicologicamente, $\dot{e}$, financeiramente, em tudo por tudo né? Porque eu já passei por essa experiência, moro na casa da minha sogra, e um dia que eu pretender ter um vai ser planejado por Deus e segundo por mim e meu esposo né?" [Neide].

A insegurança econômica também faz parte das preocupações de Dalva com a relação à perspectiva de uma nova gravidez. Assim ela se refere:

"Francamente, por enquanto, eu não quero não. Porque esse foi um choque muito grande e pra mim, ter um agora eu... Num tem... Eu tenho certeza que se eu pegar um agora, por uma parte ia ser bom... Mas por outa parte... Logo eu me preocupo muito. Eu sou uma pessoa que me preocupo muito. (...). Porque primeiro, não tenho casa própria. A casa é de aluguel. Meu marido ganha sessenta reais por semana, servente já tá dizendo né? Minha mãe e minha irmã é quem me ajuda bastante. (....). ...o médico falou pra mim que meu útero tava muito estreito então eu fizesse por onde não pegar outo agora. Deixasse passar uns tempo" [Dalva].

“... Então Deus sabe, toda hora né? O que é de ser será. Eu penso assim. Se ele não me deu esse agora então ele vai entender meu pobrema. Eu não quero um agora. Se vim tudo bem. Tá na mão dele. Mas depender de mim, agora não. Enquanto eu puder tomar remédio... " [Dalva].

Franca tem um filho com onze anos de idade. Mencionou que teve receio na sua última gravidez, “Eu tinha medo assim, quando eu fosse ter. Se acont... Alguma coisa que acontecesse. Pudesse ser que eu morresse”. A justifica para o seu medo “.. por causa da..., da minha idade já, né”. Em seus planos incluía: "É, se eu tivesse... se ele tivesse nascido, tivesse vivido né? Eu tinha tido ele e tinha feito uma ligação. Ai pronto. Tinha ficado com dois filho né"? 
Para Cristina, a possibilidade de uma nova gravidez é encarada da seguinte maneira:

“(...). Porque agora eu não pretendo ter outro filho. Eu tô me senti... eu ainda me sinto muito magoada por dentro, né, de ter outro filho. Eu acho que se eu ficasse grávida agora eu não ía ser uma boa mãe, porque eu ia ficar me lembrando muito do meu primeiro, ou talvez eu ia ter muita lembrança, eu ia querer no caso que o meu outro filho fosse parecido com o primeiro. Então, agora eu não queria ter outro" [Cristina].

Maria responde à possibilidade de uma outra gravidez da seguinte forma:

"Mas eu. eu, eu, ainda penso assim. em ter outro né. Mas eu vou e falo assim 'deixa passar o trauma primeiro, pra depois vê se realmente eu quero ou não outro, outro filho'" [Maria].

MARTINS e col. (1998) referem que enquanto perda do objeto amado o esperado é que ocorra a elaboração do luto.

Em relação ao mencionado pelas autoras pudemos identificar que apenas Cristina e Maria vincularam a sua decisão por uma nova gravidez à resolução da perda sofrida. 


\section{Produção de sentido na experiência da perda perinatal}

Antes de tudo deixemos claro o uso do termo sentido.

São várias as acepções dadas ao termo sentido. Porém, o conteúdo atribuído à noção de sentido no presente estudo compartilha da mesma idéia registrada por Mary Jane SPINK (2000) no seu livro intitulado "Práticas discursivas e produção de sentidos no cotidiano", a qual já foi referida na introdução desse trabalho. Contudo, uma retomada ao termo sentido, a partir de um trecho da autoria do escritor português José Saramago, citado por SPINK, não se torna demais nesse momento.

Sobre os sentidos...

"Ao contrário do que em geral se crê, sentido e significado nunca foram a mesma coisa, o significado fica-se logo por aí, é directo, literal, explícito, fechado em si mesmo, unívoco, por assim dizer; ao passo que o sentido não é capaz de permanecer quieto, fervilha de sentidos segundos, terceiros e quartos. de direcções irradiantes que se vão dividindo e subdividindo em ramos e ramilhos, até se perderem de vista, o sentido de cada palavra parece-se com uma estrela quando se põe a projectar marés vivas pelo espaço fora, ventos cósmicos, perturbações magnéticas, aflições" [José Saramago].

Entre tantos... Fiquemos mesmo por aqui.

Importa agora esclarecer em que consiste esse capítulo.

Depois de todo o trajeto até então realizado, decidimos por compor esse capítulo priorizando as seguintes questões de base da nossa pesquisa: Como as mulheres enunciam e julgam a experiência da perda do filho?

No entanto, considerando que a vivência da perda está inserida no contexto do processo reprodutivo da mulher. notadamente no período da gravidez e no momento 
do parto ou nos primeiros dias após o parto, achamos por bem começar situando a temática da saúde e dos direito reprodutivos a partir da qual inseriremos especificamente a problemática do parto.

\subsection{Do Programa de Assistência Integral à Saúde da Mulher (PAISM) às noções de saúde e direitos reprodutivos.}

$\mathrm{Na}$ abordagem sobre o tema da saúde reprodutiva não há como deixar de resgatar a importância do PAISM, lançado em nosso país pelo Ministério da Saúde em 1983. Tal importância pode ser evidenciada através do significado social que assume - ao se destacar como uma proposta de mudança no tocante a forma como até então a saúde das mulheres vinha sendo tratada -, ao incorporar no seu conteúdo os princípios da integralidade e universalidade da atenção à saúde.

A inserção do conceito da atenção integral à saúde da mulher no PAISM trouxe, por assim dizer, uma nova dimensão ao significado do corpo feminino, expressada através da mudança de posição das mulheres no contexto social. Ao situar a reprodução dentro de um contexto mais amplo de atenção à saúde da mulher o PAISM rompeu com a antiga lógica, de parcialização do corpo feminino, norteadora das intervenções até então preconizadas. Nesse contexto as mulheres deixaram de ser vistas apenas como parideiras, e o cuidado de sua saúde não mais se restringiria à atenção pré-natal, ao parto e puerpério.

Como consequiência do novo enfoque, as ações voltadas à regulação da fecundidade passaram a ser concebidas como uma parte da atenção integral à saúde oferecida às mulheres e não mais como um fim em si mesmo. 
No cenário mundial, segundo RAVINDRAN (1995) op. cit. OSIS (1998), o PAISM foi pioneiro ao propor o atendimento à saúde reprodutiva das mulheres e não mais a utilização de ações isoladas em planejamento familiar.

Apesar da a expressão "saúde reprodutiva" não estar presente na proposta original do PAISM, a concepção de atenção integral à saúde acha-se contemplada na noção de saúde reprodutiva adotada pela Organização Mundial da Saúde em 1988, ampliada e consolidada Cairo em 1994 e em Beijing em 1995 (OSIS 1998).

O conceito de saúde reprodutiva formalmente apresentado na Conferência Internacional sobre População e Desenvolvimento (CIPD) realizada em Cairo em 1994 apresenta o seguinte teor:

"A saúde reprodutiva é um estado de completo bem estar fisico, mental e social em todas as matérias concernentes ao sistema reprodutivo, suas funções e processos, e não a simples ausência de doença ou enfermidade. A saúde reprodutiva implica, por conseguinte, que a pessoa possa ter uma vida sexual segura e satisfatória, tendo a capacidade de reproduzir e a liberdade de decidir sobre quando e quantas vezes devem fazê-lo. Está implícito nesta última condição o direito de homens e mulheres de serem informados e de terem acesso aos métodos eficientes, seguros, aceitáveis $e$ financeiramente compativeis de planejamento familiar, assim como a outros métodos de regulação da fecundidade cuja escolha não contrarie a lei, bem como ao direito de acesso a serviços apropriados de saúde que propiciem às mulheres as condições de passar com segurança pela gestação e pelo parto, proporcionando aos casais uma chance melhor de ter um filho sadio" (SCAVONE 1999 p.32). ${ }^{19}$

Nesse conceito é possível observar uma dupla dimensão:

1) $\mathrm{O}$ reconhecimento dos direitos reprodutivos como direitos humanos (incluindo homens e mulheres) - Condenando qualquer tipo de "discriminação,

\footnotetext{
${ }^{19}$ A formulação desse conceito na CIPD (CAIRO, 1994) foi resultado de muitas lutas políticas travadas com os atores sociais que participaram do fórum, incluindo representantes de quase todos os paises do mundo. (SCAVONE L. - Anticoncepción, aborto y tecnologías conceptivas: entre la salud, la ética y los derechos. In: . (orgs.). - Género y Salud Reproductiva en America Latina. Cartago:Libro Universitario Regional, 1999).
} 
coação ou violência" que possam vir a interferir nas decisões reprodutivas. E garantia à mulher de uma reprodução sadia, e parto seguro, possibilitando assim o nascimento de um filho também sadio.

2) Da saúde sexual, como parte integrante da saúde reprodutiva, afirmando que "a pessoa tem direito a uma vida sexual segura e satisfatória" podendo ainda decidir, se, quando e com que freqüências desejam se reproduzir. Define assim, "o propósito da vida sexual como intensificação da vida e das relações pessoais, não apenas o aconselhamento e os cuidados relacionados com a reprodução e com as doenças sexualmente transmissiveis" (BARBOSA e PARKER 1999 p.19).

É importante considerar que os eventos realizados no Cairo e em Beijing têm contribuido fortemente para a emissão de conceitos, como por exemplo, referentes à igualdade de direitos entre homens e mulheres, à liberdade e a autonomia na definição da vida sexual e reprodutiva, aos compromissos dos governos com a regulação da fecundidade e a adoção dos direitos das mulheres, que incluem os direitos sexuais e reprodutivos.

Segundo OSIS (1998), o PAISM representou um passo significativo em direção ao reconhecimento dos direitos reprodutivos das mulheres, mesmo antes que essa expressão ganhasse os diversos foros internacionais de luta. Apesar disso, partindo da informação de outros autores ela afirma que a implementação efetiva do PAISM em todo o território nacional não aconteceu em conseqüência da morosidade, do descompasso entre a discussão, o planejamento e as medidas práticas, traduzindo a falta de compromisso político para com a implementação do programa.

Contudo, para a autora, tal fato não pode ser analisado isoladamente. Pois, juntamente com a inoperância do programa aparece o caos de todo um sistema 
público de saúde, no qual, tanto a saúde das mulheres, como a saúde das crianças, dos homens, e da população em geral, não recebem a atenção necessária nos serviços públicos. A deterioração dos serviços públicos de saúde é generalizada. Enquanto política o SUS não tem conseguido firmar-se em termos de resultados positivos para a população em geral.

Não obstante, a adoção do PAISM representou um passo significativo em direção ao reconhecimento dos direitos reprodutivos das mulheres, mesmo antes dessa expressão ganhar os diversos foros internacionais de luta (OSIS 1998).

Os termos direitos sexuais e reprodutivos configuram-se de maneira mais efetiva nas Conferências Internacionais de Cairo sobre População (1994) e da Mulher em Beijing (1995), inserindo-se, a partir de então, no discurso internacional dos direitos humanos.

Tanto o Programa do Cairo como a Plataforma de Beijing definem direitos reprodutivos como sendo:

"O reconhecimento do direito básico de todos os casais ou individuos decidirem livre e responsavelmente o número, o espaçamento e a freqüencia com que terão filhos, o direito à informação e aos meios para isso, e o direito de atingir o mais alto padrão de saúde sexual e reprodutiva. No que diz respeito à reprodução, essa definição também inclui o direito de tomar decisões livres de discriminação, coação e violência, como expresso nos documentos dos direitos humanos" (BARBOSA e PARKER 1999 p.21)

Ao inserir direitos sexuais e reprodutivos como direitos humanos, especifica LONDAÑO (1995 p.71) citado por ÁVILA e GOUVEIA (1996 p.165-166):

"Estamos nos referindo à fertilidade-infertilidade-fecundidade; às condições e ambientes propicios às mesmas; optar livremente pela maternidade; legislação favorável, serviços seguros e com qualidades para fazer interrupções da gravidez; educação sexual, informação, acesso e liberdade na escolha e uso de métodos contraceptivos, proteção contra DST 
e AIDS, estudo e apoio adequado para trabalhadores do sexo: reconhecimento do prazer sexual como um direito inerente às pessoas; respeito pelas orientações e exercicio intimo da sexualidade; ênfase na igualdade de responsabilidades entre homens e mulheres, na educaçâo das crianças; incluir as mulheres na formulação ética/legal e garantir sua presença nas instâncias que decidam sobre tecnologias e pesquisas reprodutivas". 20

Em outros termos, pensar em direitos sexuais e reprodutivos é reportar aos apelos de auto - realização, autonomia e expressão cultural das necessidades individuais e sociais - introduzidos nos anos 60 e expressados na palavra de ordem feminista "nosso corpo nos pertence".

Essa condição essencial da posse do próprio corpo, manifestada nas vozes das mulheres e instaurada na dimensão da vida cotidiana ${ }^{21}$, com atribuições de direitos, desejos, responsabilidades, construídas e vividas com autonomia, torna-se fundamental para a constituição da mulher como pessoa integral (ÁVILA e GOUVEIA 1996). A necessidade de auto - realização e autonomia, segundo MELUCCI (1994) citado por ÁVILA e GOUVEIA (1996), portanto, não se desdobra apenas na organização dos movimentos sociais, mas conforma também um novo ethos, onde a individualidade, a subjetividade passa a ser elementos importantes da vida social.

\footnotetext{
${ }^{20} \mathrm{O}$ tema dos direitos reprodutivos, construído e usado no âmbito internacional, apresenta variação na sua definição nos diferentes paises. Não obstante essa constatação, a luta é pela integridade das mulheres e sua autonomia, enquanto sujeitos capazes de escolherem e decidirem por si próprias (ÁVILA MB, GOUVEIA T. Notas sobre Direitos Reprodutivos e Direitos Sexuais. In: PARKER, R., BARBOSA, R.M. (orgs.). Sexualidades Brasileiras. Rio de Janeiro: Dumaré/ABIA/IMS: UERJ, 1996).

${ }^{21}$ A vida cotidiana, como afirma HELLER (1989:18) citado por ÁVILA e GOUVEIA (1996:162), "é a vida do homem inteiro; ou seja, o homem participa da vida cotidiana com todos os aspectos de sua individualidade, de sua personalidade". Isto se dá pelo fato de que "o cotidiano nos evoca a idéia do desenrolar da vida, do nosso estar no mundo, das coisas que experimentamos a cada instante" (idem, p. 162). "Pensar a dinâmica social a partir da idéia de cotidiano trás em si uma modificação na própria compreensão da sociedade, na medida em que este conceito não implica numa dicotomização tão estreita como quando se analisa em termos de público e privado" (idem, p.162).
} 
O aprimoramento do conceito de direitos reprodutivos trouxe, portanto, uma nova perspectiva para a idéia de liberdade reprodutiva no sentido de não mais contrapor contracepção e aborto a uma maternidade obrigatória. Estas questões, (re) elaboradas como espaços de vivências da cidadania, e a gravidez e o parto vividos com segurança e dignidade, tornam-se temas fundamentais na obtenção desses direitos (ÁVILA e GOUVEIA 1996 p.164).

Encarada como proposta de um novo código ou como uma nova designação para as questões da vida social, difundidas, segundo a autora "por um movimento politico de construção e afirmação de sujeitos", os direitos reprodutivos constituemse por assim dizer, no enfrentamento que se faz em defesa dessas questões, rompendo com antigos códigos de comunicação tradicionais ${ }^{22}$ (p.164).

\subsection{O parto no contexto da saúde e dos direitos reprodutivos}

Mesmo com os avanços alcançados na área da obstetrícia, influenciados pelo desenvolvimento das novas tecnologias, resultando na melhoria dos padrões de morbimortalidade materna e perinatal, a saúde reprodutiva permanece um problema na maioria dos países em desenvolvimento. Isso, em grande parte se deve à precariedade das condições de vida da população e dos sistemas de saúde, cujas deficiências quantitativas e qualitativas e distribuição desigual e injusta, resulta num grande número de excluídos que não tem as suas necessidades atendidas e expectativas preenchidas.

\footnotetext{
${ }^{22}$ No velho código as mulheres eram apenas receptáculo da norma, do discurso proferido sobre elas e o uso do seu corpo (Idem, p.164).
} 
No âmbito da saúde reprodutiva, a gestação, parto e puerpério são processos fisiológicos atribuídos de significado segundo a especificação de cada cultura, a qual apresenta formas próprias de sentir e de se comportar socialmente.

No espaço delimitado pelo chamado processo reprodutivo, o parto talvez possa ser considerado como o mais importante, por imprimir o sentido de um remate. A conclusão da primeira etapa de uma obra.

A precariedade da situação vivenciada por grande número de mulheres brasileiras com respeito à assistência a saúde reprodutiva pode ser conferida por meio de informações obtidas a partir dos coeficientes de mortalidade perinatal e de morte materna. No Brasil, segundo TANAKA (1998), mesmo levando-se em conta a sub-notificação de informações, a magnitude da morte materna, por exemplo, é considerada muita elevada (67 por 100.000 para o ano de 1996, segundo dados oficiais) quando comparada com países desenvolvidos como Canadá e Estados Unidos (4 e 9.6 por $100.000 \mathrm{NV}$ ). As causas de óbito materno, por exemplo, no Brasil, são devidas, em mais de $90 \%$, às causas obstétricas diretas e apenas $10 \%$ a causas obstétricas indiretas. $^{23}$

De acordo com a autora, um dos grandes problemas que se coloca em relação à situação é que, apesar de $75 \%$ das gestantes brasileiras realizarem o pré-natal (essa cobertura de atendimento à gestante não representa qualidade da assistência), a quase totalidade dos serviços públicos de saúde não tem para onde referir a mulher em trabalho de parto ou uma gestação de alto risco que necessite de cuidados mais

\footnotetext{
${ }^{23}$ Dentre as causas obstétricas diretas destacam-se as doenças hipertensivas especificas da gravidez, as hemorragias, as infecções puerperais e o os abortos. Causas estas que seriam evitáveis com os atendimentos de pré-natal, parto e puerpério adequados e resolutivos, e em relação ao aborto, ações efetivas de planejamento familiar e acesso aos serviços para interrupção da gravidez com segurança. Dentre as causas obstétricas indiretas incluem-se as cardiopatias, embolias pulmonares, diabetes, entre outras (TANAKA ACd'A. Saúde da mulher brasileira. In: CIANCIARULLO TI, GUALDA DMR,
} 
totalidade dos serviços públicos de saúde não tem para onde referir a mulher em trabalho de parto ou uma gestação de alto risco que necessite de cuidados mais qualificados. Este fato faz com que a gestante tenha que "peregrinar" por diversos serviços de saúde antes de ser atendida, derivando daí a possibilidade de a gestante chegar ao serviço de saúde em péssimas condições de parto. O risco decorrente da situação e a vulnerabilidade da gestante são agravados pela frágil relação instituída entre a equipe de saúde e a paciente.

Diante do reconhecimento dessa grave situação o conceito de saúde e de direitos reprodutivos se impõem inspirando um novo discurso e norteando novas ações normativas, visando colocar a mulher e a família no pleno exercício de cidadania, garantindo segurança e dignidade no atendimento à gestação e ao parto.

Numa assimilação dos conceitos de saúde e direitos reprodutivos antes mencionados, o Programa de Humanização no Pré-natal e Nascimento (PHPN), que foi instituído no Brasil, através da Portaria 569/GM de 01 de Junho de 2000, apresenta no seu discurso a perspectiva de assegurar a melhoria do acesso, da cobertura e da qualidade do acompanhamento pré-natal, da assistência ao parto e puerpério. A referida Portaria estabelece, dentro dos seus princípios e diretrizes, as responsabilidades das autoridades sanitárias, nos âmbitos federal, estadual e municipal, quanto à garantia dos direitos inalienáveis da cidadania à mulher no decorrer da gestação, parto e puerpério, e recém-nascidos no período neonatal (BRASIL 2000b).

Os trechos abaixo são representativos desse novo discurso ético, atento ao respeito e as singularidades individuais. 
"Uma gravidez com segurança requer cuidados da própria gestante, do parceiro, da familia e, especialmente, dos profissionais de saúde (...). Cabe à equipe de saúde, ao entrar em contato com uma mulher gestante, na unidade de saúde ou na comunidade, buscar compreender os múltiplos significados da gestação para aquela mulher e sua familia (...). O contexto de cada gestação é determinante para o seu desenvolvimento bem como para a relação que a mulher e a familia estabelecerão com a criança desde as primeiras horas após o nascimento (...). Um contexto favorável fortalece os vinculos familiares, condição básica para o desenvolvimento saudável do ser humano". (BRASIL 2000a, p.7)

Por fim. dentro desse novo enfoque também se vê ressaltar a importância da subjetividade individual, inerentes aos sentimentos humanos, e a necessária solidariedade e acolhimento à gestante e a sua familia.

"A história de cada mulher grávida deve ser acolhida integralmente, a partir do relato da gestante $e$ de seus acompanhantes. Contando sua história, as grávidas esperam partilhar experiências e obter ajuda (...). $O$ diálogo franco, a sensibilidade e a capacidade de percepção de quem acompanha o pré-natal são condições básicas para que o saber em saúde seja colocado à disposição da mulher e sua família - atores principais da gestação e partos. Uma escuta aberta, sem julgamentos nem preconceitos, que permita à mulher falar de sua intimidade com segurança, fortalece a gestante no seu caminho até o parto e ajuda a construir o conhecimento sobre si mesma, levando a um nascimento tranqüilo e saudável". (BRASIL 2000a, p.8).

\subsection{Na encruzilhada do parto}

Gestação, parto e puerpério são exemplos de processos fisiológicos atribuídos de significado na especificidade de cada cultura, que designam formas apropriadas de sentir e de se comportar socialmente.

De todos eles talvez o parto seja o mais importante por culminar todo o processo. Do ponto de vista fisiológico, pela brevidade do seu transcurso, pela súbita transformação que causa ao organismo materno, por ocasionar e por propiciar a 
manifestação de intercorrências desenvolvidas ao longo do período pré-concepcional, pré-natal ou no seu transcorrer. Do ponto de vista cultural, por se constituir numa crise do ciclo vital envolta em rituais, por simbolizar as maneiras como as mulheres vivenciam essa experiência individual e coletivamente e por ter propiciado freqüentes confrontos entre concepções populares e concepções profissionais predominantemente hegemônicas, que tem tornado parturientes alvo de condutas iatrogênicas, desumanizadas etnocêntricas no contexto atual do país (GUALDA 1998).

\subsubsection{Anotações sobre a história da assistência ao parto}

Segundo TANAKA (1995), a assistência ao parto, até o final do século XIX, era feita, em sua grande maioria em domicilio e por obstetrizes/parteiras.

Citando ARRUDA (1989) refere a autora que nesse período a preocupação da medicina com o corpo da mulher não se restringia a questões científicas, mas visava, sobretudo, a sua normalização e controle.

Ainda ao final do século XIX e início do século XX, médicos e obstetrizes passam a disputar espaço pela assistência ao parto. Na disputa empreendida os médicos assumem cada vez mais o lugar das obstetrizes e estas perdem gradativamente o seu campo de atuação. Essa luta inicialmente travada na Inglaterra tende a espalhar-se por toda a Europa (TANAKA, 1995).

A partir de então, com o aumento gradativo de médicos na assistência ao parto, o manejo de novas tecnologias - anestesia, anti-sepsia, uso de antibióticos e hemoterapia -, e a transferência da realização dos partos para o hospital, estes se tornaram mais seguros, não só para a mulher como também para o recém-nascido. 
Segundo TANAKA (1995), a institucionalização do parto em São Paulo, repercutindo sobre a diminuição do parto domiciliar, ocorreu por volta da década de sessenta, momento em que houve por parte do governo investimento na construção e expansão da rede hospitalar pública.

Assim. o aperfeiçoamento do uso de novas tecnologias, a construção de novos hospitais, e a ausência de apoio à realização de partos no domicílio, resultaram na criação da necessidade do parto hospitalar por parte da população.

Em 1975, a 5 - Conferencia Nacional de Saúde torna público o Programa de Saúde Materno-Infantil, elaborado pelo Ministério da Saúde do Brasil. A argumentação utilizada pelo referido programa incluía que o parto hospitalar era mais seguro e que a mortalidade materna e perinatal era muito menor quando ocorria no hospital (TANAKA 1995).

Porém. a incorporação do parto institucional não foi seguida de uma política de saúde capaz de absorver a nova demanda, nem de diretrizes visando a integração, a regionalização e hierarquização dos serviços de saúde.

Dessa forma, segundo TANAKA (1995), nas décadas de setenta e oitenta, as mulheres filiadas ao INPS/INANPS quando chegavam no final da gestação retiravam uma guia de internação para serem assistidas por hospitais próprios ou credenciados pelo órgão. As mulheres não filiadas ao Instituto e que não podiam pagar pelo parto, recorriam a instituições de ensino, hospitais públicos ou filantrópicos.

Inicia-se aí a peregrinação da gestante por uma assistência hospitalar ao parto.

Diversos modelos de políticas para o setor saúde foram implementados, no sentido de tornar acessivel essa parcela da população privada de assistência, através do estabelecimento de formas de pagamento a hospitais conveniados/contratados 
como, por exemplo, o Plano de Pronta Ação (PPA) e a Autorização de Internação Hospitalar (AIH).

Com a nova Carta Constitucional de 1988 - artigo 196 da sessão II da saúde - a saúde passa a ser considerada um direito de todo o cidadão e dever do Estado, o qual deve ser garantido através de políticas sociais e econômicas visando a redução do risco de doença e de outros agravos, além do acesso universal, igualitário às ações e aos serviços para a sua promoção, proteção e recuperação.

A constituição de um sistema único de saúde, sob a forma de uma rede regionalizada e hierarquizada, para desenvolvimento das ações e serviços públicos de saúde, acha-se descrita no artigo 198 da mesma seção II.

No entanto, a proposta do SUS de possibilitar acesso universal ao parto hospitalar gerou maior dificuldade de internação das parturientes em hospitais filantrópicos e conveniados/contratados com o INAMPS. A decorrência disso, segundo TANAKA (1995), deveu-se: 1) À forma de pagamento (pouco atraente para a rede conveniada, contratada e filantrópica); 2) aumento da demanda para o setor público (que passou a ser referência para o setor privado de casos considerados "nãorentáveis", com agravamento da falta de leitos públicos).

Como conseqüência, a peregrinação por um leito se tornou mais intensa no periodo, acarretando maiores danos à saúde do binômio mãe-filho.

Outra distorção gerada pela crise do financiamento do setor saúde apontada por TANAKA (1995) consistiu no privilegiamento da produtividade em detrimento da qualidade da assistência. Com isso o indivíduo deixou de ser visto como um ser humano a ser atendido em suas necessidades, passando gradativamente a ser tratado como um número a mais a ser faturado. 
A desumanização do setor da saúde é apontada pela autora como tão grande que durante $o$ atendimento a prioridade é dada aos trâmites burocráticos em detrimento da atenção ao paciente. Nesse contexto, nascimento e morte não são considerados com dignidade. Tanto o doente quanto a sua família mendigam por atenção no serviço de saúde.

No estudo realizado por TANAKA (1995), o qual tomamos como referência para proceder a essa breve narrativa, a autora trata sobre a questão da morte materna gerada pela peregrinação da mulher para obter assistência hospitalar na hora do parto. Vale ressaltar que essa peregrinação expõe tanto a parturiente como o seu concepto.

\subsubsection{Considerações clínicas do momento do parto}

O momento do parto é apreendido pela mulher através do reconhecimento de alguns sinais os quais são motivadores da procura por ajuda.

A hora do parto comumente é indicada por dois acontecimentos iniciais: contrações dolorosas e rompimento da bolsa das águas.

Clinicamente falando a sensação de endurecimento da barriga é percebida durante toda a gravidez, porém, diferentemente do que acontece na hora do parto, não são dolorosas nem acompanhadas de cólicas (MARQUES e DUARTE 1998).

De acordo com os autores, na hora do parto as contrações passam a ser dolorosas e ritmadas. Porém, o quanto dói não é fundamental, já que o limiar de dor varia de pessoa para pessoa. O que importa é o ritmo das contrações dolorosas. No início do trabalho de parto as contrações dolorosas são mais espaçadas - de meia em 
meia hora, de quinze em quinze minutos, de dez em dez minutos - é o que se designa habitualmente pré-parto. Ao evoluir para o verdadeiro trabalho de parto o ritmo das contrações dolorosas tendem a diminuir para duas a três a cada dez minutos.

Os autores lembram que a evolução para o verdadeiro momento do parto pode também não acontecer, às vezes esse periodo pode não existir e as contrações já começam com pequenos intervalos. Nas primigestas o pré-parto é mais comum do que naquelas mulheres que já tiveram partos normais.

A ruptura da bolsa amniótica (bolsa das águas) quando acompanhada de contrações fortes indica habitualmente a proximidade do parto. O liquido amniótico contido na bolsa, quando normal apresenta coloração clara "como água de coco ou meio esbranquiçada", diz MARQUES e DUARTE (1998 p.50), não devendo apresentar a coloração esverdeada, pois isso significa a eliminação fetal de mecônio dentro da bolsa. Clinicamente esse é considerado um sinal indicativo de sofrimento fetal.

O surgimento de sangramento na gravidez pode caracterizar um dos primeiros sinais de que a gravidez não vai bem. No início da gestação, se acompanhado ou não de cólica, entre outros problemas, pode significar uma ameaça de aborto. Porém, segundo MARQUES e DUARTE (1998), durante as "primeiras 16 semanas de gravidez, podem ocorrer sangramentos perfeitamente normais" (p.35). No segundo trimestre da gravidez o sangramento pode ser ocasionado pela implantação baixa da placenta, no segmento inferior do útero ou na região do colo - placenta prévia. No terceiro trimestre o sangramento vaginal é considerado mais grave, pois pode representar o descolamento da placenta. Nos três casos de sangramento, além de 
repouso, recomenda-se a procura do serviço de saúde e realização de ultrasonografia.

\subsubsection{Sobre o trabalho de parto: primeiros relatos}

O parto, assim como outros processos fisiológicos - beber, comer, as relações sexuais e o morrer - não é um ato puramente biológico. Acima de tudo o parto é um ato cultural e reflete os valores de cada sociedade humana.

\section{- Sinais do parto}

Trataremos nesse tópico sobre as formas de expressão das mulheres entrevistadas acerca da percepção sobre o início do trabalho do parto.

Entre as mulheres que participaram dessa pesquisa a contração uterina foi o sinal mais freqüentemente citado como manifestação do momento do parto.

No entanto, a percepção da dor por parte das mulheres variou bastante quanto à forma de apresentação, início, intensidade, duração, ritmo, etc.

O reconhecimento da dor relacionada ao momento do parto variou também se a mulher era primigesta ou não. Esse fato, em certa medida, condicionado à experiência anterior serviu de orientação à mulher com relação ao momento de procurar o serviço de saúde.

Com relação especificamente à "dor do parto" vale a pena ressaltar alguns trechos das entrevistas que se seguem:

Carmem, primigesta, em diversos momentos da sua entrevista chamou atenção sobre a peculiaridade da dor instalada ao completar os nove meses de gestação. 
Segundo ela, era uma dor diferente do tipo descrito pelos profissionais de saúde nas reuniões do pré-natal das quais ela havia participado.

“... ai eu comecei a sentir... (....). ... eu só sentia umas dores nas minhas costas, na minha coluna. Era uma dor, assim, insuportável, que eu não conseguia nem dormir. (....)" [Carmem].

Carmem refere que não se tratava de contração uterina: "Era diferente. Era diferente. Era na coluna. Chega... Eu não conseguia nem ficar em pé, nem sentada. Chega me dava um certo desconforto" [Carmem].

Na ocasião procurou o serviço de saúde para a última consulta ao pré-natal e de acordo com a sua narrativa a consulta foi conduzida da seguinte forma

"Ela não fez toque. Ela só mediu a minha barriga, disse que já tava baixa, bem baixa. Ela escutou com um negocinho, que ela botou assim, botou o ouvido. Ela escutou. Disse que tava batendo normal. E a minha barriga tava bem... bastante baixa mesmo. Ela fez as contas disse que a nenê tava no limite mesmo e que eu fosse pra maternidade. Direto pra maternidade". [Carmem]

Dalva, também primigesta, descreve o aparecimento dos primeiros sinais do trabalho de parto quinze dias antes de completar os nove meses de gestação. Assim ela relata:

“Fazia oito... fazia quinze dias... Que eu tava com essas dorzinha já. (....). Ai fui lá... (...). Pra Maternidade F. (....). Fiz o toque... (....). Ai elas disseram: 'Não, volte pra casa que n'é dia... N'é tempo inda não.' (....). 'Você é nervosa!' Tudo bem. Voltei pra casa. Quando cheguei em casa começou aquela dorzinha. (....). Aí também elas passaram um remédio pra evitar cólica. Pra diminuir a cólica. (....). Quando eu cheguei em casa ai começou... as contrações..." [Dalva]. 
Em passagens anteriores da sua entrevista Dalva refere que, dois meses antes, aos sete meses de gravidez, tivera um susto, e que desde esse acontecimento ela começou a sentir "cólicas".

"Aí aquele susto abalou a criança. (....). Ai na hora que eu fui pra médica, a médica foi e falou pra mim... Até Dra. D. e a Dra. I. disse: 'Não Dalva ... isso que você tá sentindo é supertenção. '(sic). Eu disse: 'É não mulé! Eu tô sentindo umas cólica, derna que eu levei o choque.' Ela disse: 'Não, mas isso é normal.' Aí voltei pra casa. Quando cheguei em casa... (....). Ai pronto. Ai foi que começou de lá pra cá aquelas dorzinha fina... Mas não impatava fazer nada. Ai pronto. (....). Quando começou em a... assim, pra sete, oito de abril, ai começou as contrações. (....). Eu sentindo que já tava na hora já". [Dalva]

O que poderíamos apreender dos fragmentos dos discursos apresentados por Carmem e Dalva?

Ao nosso ver os trechos citados ressaltam alguns aspectos de natureza interrelacional entre a gestante e o serviço de saúde, no qual se revela, de um lado o discurso médico-institucional normativo e do outro a percepção da mulher sobre o discurso. Revela ainda a despersonalização de certos conteúdos da comunicação. Com efeito, transparece em sua constituição a ausência de espaço e de flexibilidade necessários para o reconhecimento e colocação de possiveis diferenças.

A contração uterina, ou outras formas de sinalização da hora do parto, isoladas ou acompanhadas por outros sinais, foram referidas por Ivani, Neide, Franca.

Para Ivani, grande multípara, a percepção da dor veio acompanhada de sangramento, alertando-a a procurar o serviço de saúde. Neide referiu que o seu trabalho de parto teve início com o aparecimento de sangramento e dor de cabeça, acontecimento este surgido quinze dias antes da data provável do parto. Da mesma forma Liana (multípara) mencionou que teve o seu trabalho de parto iniciado antes 
da data provável, ou seja. vinte e dois de março, quando o previsto seria para o dia vinte e oito de abril. Diante das manifestações citadas, definidas por elas como sinais do parto a atitude foi a de busca pelo serviço de saúde.

Situando o caso específico de Liana:

"Comecei a sentir umas cólicas, muito pouca. Só cólica. Quando deu quatro e quinze da manhã fui pra maternidade. (....). ... fui atendida e elas me deram a guia pra me internar. Disse que eu ia ficar em observação, que a criança estava bem, que eu ia ficar em observação. Só que eu não... Eu fiquei com receio. Não sei o que me deu de tá lá, e, eu não fiquei. Disse que ia ligar pra minha filha e sai. Peguei o táxi, fui pra casa e, tava só. Cheguei em casa, liguei pra minha filha. As dor começou aumentar. Liguei, ela veio me buscar, me deixou aqui na Maternidade A. Cheguei na Maternidade A ... Não sei se é médico ou enfermeira que me atendeu, disse que minha criança tava bem. Que eu fosse pra casa. Passou Buscopan e que eu ficasse de repouso. Era umas oito horas da manhã. (....). Eu fiquei de repouso e quando foi umas cinco horas da tarde... Não sentia dor nenhuma. (....). Tomava o medicamento, não sentia dor e comecei a sangrar, sangrar muito... Tipo hemorragia. Só que quando eu entrei no carro pra vim, voltar pra maternidade, eu não estava com hemorragia. [Liana]

No relato feito por Liana, assim como nos que o precederam, o ponto central da elaboração discursiva parece residir em torno do contexto do atendimento representado por um espaço institucional centrado na condução técnica do caso, no qual a mulher não sente ressonância.

No entanto, é indispensável assinalar que esse não é o único problema que nos chama atenção. Ao partir dessa questão se faz notar que o espaço institucional de saúde - especialmente da clínica -, não se reduz exclusivamente à inter-relação entre profissional de saúde-paciente. Para além dessas relações, o espaço em que esta se realiza é acima de tudo um espaço social no qual se microprocessam momentos fundamentais da vida em sociedade. 
Maria tem história de duas cesáreas anteriores. Por esse motivo o seu parto estava sendo programado para ser uma terceira cesárea.

A procura de Maria pela consulta médica deu-se em função do seu estranhamento com relação aos movimentos fetais. De acordo com a sua narrativa o bebê se movimentava muito, e, uns três dias antes do diagnóstico da sua morte ele tinha mexido mais do que o habitual.

“Ai pronto. Mexeu mesmo, mesmo, no sábado. Ai no domingo já mexeu menos. A atividade diminuiu. Ai na segunda-feira, como já tinha parado mesmo assim de mexer mais, ai eu falei assim: 'Não, tá acontecendo alguma coisa'. Ai eu fui pra médica, né. Ela pediu uma ultra-som né, e ela não conseguiu auscultar. (....). Ai disse: 'Você tá sentindo mexer? Aí eu disse: 'Tô'. Ai disse: 'Tá mesmo?' Ai eu disse 'Tồ'. Mexia, mas aí, eu não sei se eu queria que mexesse realmente, ou se era aquelas contrações como se o feto já tinha parado, ou se era aquelas contrações do próprio organismo querendo expulsar, né. Mas eu sentia, a barriga ficava endurecida. as contrações não eram como era antes, aquelas contrações mais intensas, era diminuidas, umas contrações diminuidas" [Maria].

No que tange ao discurso de Maria, a sua análise pode converter-se em uma estrutura teórica e metodologicamente fértil para dar conta da real complexidade do problema que o envolve, a relação mãe-gravidez/bebê-cuidado. No entanto, essa dimensão enunciativa que a fala de Maria revela é apenas uma faceta constitutiva da produção de sentido do seu discurso.

Até o presente momento o que foi mostrado em cada narrativa sobre os momentos decisivos que antecederam ao parto e a busca por ajuda, remete a nossa análise no sentido de tentar desvelar a produção de significados, auto e heteroreferidos, por parte das mulheres entrevistadas - traduzidas por um conjunto pertinente de relações sociais e elementos institucionais. 


\subsubsection{A percepção da mulher sobre o nascimento e morte do concepto}

Esse tópico inclui narrativas sobre o processo do parto, a demanda por atendimento, a percepção da assistência durante o pré-parto e parto, no qual se inclui a relação com os profissionais de saúde. Mostra o percurso realizado pela mulher por vários serviços de saúde até ser admitida para realização do parto, e as intercorrências resultantes da demora pelo atendimento adequado - "a perda do momento ideal" (TANAKA 1995) - e a morte.

Antes da admissão da mulher pelo serviço de saúde durante o trabalho de parto a peregrinação esteve presente na maior parte das histórias narradas. Os relatos a esse respeito mostraram-se estarrecedores. Ilustraremos com alguns casos.

- $O$ caso de Íris:

Íris refere em sua narrativa que quando as suas contrações tiveram inicio procurou o serviço de saúde. Foi um longo percurso de idas e vindas.

\section{Serviço de Saúde A [1]}

"Eu passei o dia todinho sentindo dor. Eu vim pra cá à noite, de nove horas. (....). Ai eu cheguei aqui, eles me examinaram. Aí disseram que não tava perto de ter o bebê não. Perguntaram se eu agüentava ir pra casa. Se apertasse eu voltava. Eu disse que agüentava. Que eu não tava com muita dor, sabe?" [Íris].

\section{Serviço de Saúde A [2]}

"Ai quando foi na segunda - feira, de sete horas, me acordei com dor. Ai as dor já era pra ter, que eu não agüentava mais não. Era doendo, doendo e eu andando no corredor. (....). Aí tomei banho (...), vim pra cá de dez horas. Ai cheguei aqui, fiquei ali. Ai tinha um bocado de gente que eles estavam examinando ainda. Ai depois eu entrei. Ai eles me examinaram. me examinaram, ai disseram que eu tava com oito centímetros e que não tava perto de ter menino ainda não. Ai, mandar... Não tinha vaga aqui. Mandaram eu ir pra o Hospital D. " [Íris]. 
Íris foi encaminhada de ambulância para o serviço de saúde D.

Serviço de Saúde D [3]

"Ai quando eu cheguei lá o doutor veio me examinar. Aí eu disse que não queria ser mais examinada porque doía demais examinar. Ai ele disse: 'Mas não dói não.' Ai eu disse: 'Tá bom.' (....). Ai ele rompeu a bolsa. Que a bolsa ainda não tinha rompido" [Íris].

Procedimento no serviço de saúde D: Indução do parto

"Ai mandou eu ir no banheiro tomar banho e tentar fazer xixi. Ai eu fui. Ai eu fiquei em pé, que eu tive medo de agachar e o menino cair. [Rindo] $A i$ fiquei em pé e não conseguia... Ai eles me levaram pra máquina (sic) lá de ganhar bebê. Ai me deitaram lá e a mulher me aplicou uma injeção de força e botou um soro assim em mim " [Íris].

Complicação: Prolapso do cordão umbilical

"Ai eu fiquei lá. Ai o doutor passou bem uma meia hora... Ai depois que ele veio. Ele foi, me examinou... Ai disse que eu não podia ter normal. Que eu podia ter normal, mas só que tinha vindo o cordão umbilical do menino primeiro, sabe? Ai ele disse se nascesse o menino na mesma hora ele morria. Ai botaram eu de bunda pra cima, porque senão o bebê passava. Aí me trouxeram de lá... (....). Pra ele não sair. (....). Ai me encaminharam de lá pra cá de novo, na ambulância. E eu comecei a chorar. Me bateu logo um tremelique, um nervosismo. Eu me tremia todinha." [Íris].

\section{Serviço de Saúde A [4]}

Íris retornou a Maternidade $\mathrm{A}$, onde foi admitida para a realização do seu parto.

Portanto, até o momento da sua admissão Íris peregrinou por pelo menos três serviços de saúde. Ao ser admitida pelo hospital que a havia recusado inicialmente, por falta de vaga, o seu filho estava em sofrimento fetal por asfixia mecânica devido ao prolapso de cordão umbilical. Como interpretar o contexto da narrativa de Íris? Que leitura se pode fazer diante da obviedade do que foi exposto?

Íris foi internada e seu parto foi cirúrgico. Sobre as condições de nascimento do bebê e as informações sobre o recém-nascido ela diz: 
"Ai eles disseram que tava tudo bem com ele. Que ele só tinha nascido roxinho, por causa que passou do tempo. Não! Não passou do tempo. Eles disseram só assim: 'Ó, o teu bebê nasceu roxinho, mas não tem problema não. Ele vai pro berçário.' Eu disse: 'Tá bom.' Ai ela colocou ele pra mim dá um beijinho nele, eu dei. Ai ela levou ele pra lá" [Íris].

Dentre todas as entrevistadas Íris foi à única que acompanhou de perto e por mais tempo a evolução do adoecimento do filho até o desfecho da sua morte. Após o nascimento o recém-nascido foi encaminhado para a UTI neonatal. De acordo com a sua narrativa, durante o período em que esteve na UTI a criança apresentou momentos de melhora e de piora do seu quadro clínico, ao qual ela atribuiu ao atendimento realizado por alunos. Sobre isso ela diz:

"Quando ela cuidava dele de cinco horas até meio dia ele ficava bonzinho [referindo-se a médica]. Ela tirava o oxigênio dele e tudo. Ai quando ela deixava na mão dos outros, que eram os que tão... tava aprendendo, ele ficava pior. (....). Ai, quando foi um dia que ela chegou ela notou. Ela disse: 'Esse menino da Íris quando eu cuido dele ele fica bonzinho. Eu tiro até o oxigênio dele e tudo. E por quê que quando eu deixo com vocês... quando eu chego o menino tá pior?' Ai eles não falaram nada. Ficaram calado" [Íris].

Íris estabeleceu forte crítica em relação à assistência ao seu filho e chegou a desenvolver desconfiança da equipe de saúde. Ao ser informada que seu filho havia morrido, chegou a pensar que na sua ausência o médico havia facilitado a morte. Íris desejou saber a causa da morte do seu bebê, porém não aceitou fazer necropsia ao ser informada sobre o procedimento.

Em adição as informações, as anotações feitas no cartão da gestante indicam como causa da morte: prolapso de cordão e aspiração de mecônio pela criança, insuficiência cardiaca e choque cardiogênico. $O$ bebê nasceu com três quilos quatrocentos e oitenta gramas, com cinqüenta centímetros. Ele teve um Apgar, no primeiro minuto de quatro, no quinto minuto de sete, podendo significar uma 
tendência à adaptação cardiopulmonar do recém-nascido durante o período de 1 a 5 minutos.

O que de fato acarretou a morte do filho de Íris? O que poderia tê-la evitado? Íris era uma mulher jovem, fez o acompanhamento pré-natal e estava tendo o parto do seu primeiro filho. Porém, como se pôde perceber não teve o seu parto assegurado. Ao nosso ver, a peregrinação a que foi submetida contribuiu para o desfecho da morte.

Nesse momento tendemos a considerar a questão posta por TANAKA (1995) relativamente à ausência de integração entre os três períodos (pré-natal, parto e puerpério), pois para as mulheres que utilizam o serviço público de saúde, o pré-natal é realizado sem nenhuma retaguarda hospitalar, "quer durante a gestação - nos casos complicados, que exijam internação - quer no momento do parto" (p.12).

Não podemos deixar de considerar nessa reflexão a condição de violência institucional a que foi submetida à mulher, a qual reflete uma política pública onde a saúde não é prioridade (MINAYO 1994).

Entre as mulheres entrevistadas não se percebeu grandes diferenças no tocante à peregrinação da gestante e a práxis institucional, marcada pela violência. Porém algumas particularidades merecem ser destacadas razão pela qual selecionamos alguns casos e trechos para discussão.

\section{- O caso de Carmem:}

Por recomendação médica, em sua última consulta ao pré-natal Carmem foi encaminhada para o Hospital H. Ela estava tendo contrações. O seu relato merece ser considerado: 
"Cheguei lá o médico me atendeu, fez a 'prova de toque', que é uma prova horrorosa, detestei. Ele disse que ainda não tava na hora, tava com dois centimetros (....). Ele não escutou. Ele só mandou eu ficar deitada na mesa. Fez a 'prova de toque'. depois mandou eu me vestir, e disse que eu fosse pra casa que de hoje pra manhã a nenê podia nascer. E pronto. Só isso" [Carmem].

Ao que se pode notar Carmem faz crítica ao atendimento médico recebido ao referir que o médico não escutou o seu bebê. No seu discurso ela mostra a negligência impressa no tratamento recebido.

Atendendo a recomendação médica Carmem foi para casa. Disse que sentia muitas dores. dores que segundo ela não correspondiam as descrições que haviam sido feitas nas reuniões do pré-natal. Não eram as dores que ela esperava sentir. "Aquelas dor que de cinco em cinco minutos voltava. Mas era só na minha coluna. Era um mexido que minha barriga ficava assim, como se tivesse dois nenê, partida no meio".

A impressão deixada pelo primeiro contato com o serviço de saúde e pela relação estabelecida com o médico, entremeada pelo medo e distanciamento, despertou em Carmem uma certa resistência para retornar ao hospital. Sobre isso ela comenta: "Eu disse, 'Não, não tá saindo nada, tá tudo normal, eu não vou voltar pra levar outro... outra prova de toque, que é horroroso.' O meu negócio é que eu não queria voltar". Contudo, ao perceber a eliminação de uma secreção escura - "saindo uma secreção, como um sangue. (....). Era assim um, era um sangue meio... Não era cor de sangue vermelho não. Era uma cor meio achocolatado" - retornou ao mesmo hospital.

Essa paciente em trabalho de parto, apresentando sinais indicativos de que o seu feto estava em sofrimento - clinicamente revelado através da eliminação de 
mecônio ${ }^{24}$-, teve que peregrinar por mais dois serviços de saúde, até ser admitida por um terceiro para realização do seu parto.

O risco de morte do feto foi constatado em todo o trajeto da sua peregrinação pelos serviços, porém sem resolução. Nesse caso a sua peregrinação não foi por um leito, como foi o apresentado antes, mas pela falta de condições de atendimento. As duas maternidades não estavam estruturadas para atender a urgência requerida pelo caso. Nessa altura dos acontecimentos Carmem estava informada do risco de morte que o seu filho corria, pois ia sendo alertada pelos profissionais de saúde por onde passava. Finalmente ela foi encaminhada e admitida na Maternidade A.

Sobre a experiência da sua admissão no serviço e do parto ninguém melhor do que ela para descrever:

"Quando eu cheguei aqui na maternidade esperei mais um pouquinho. (....). Ai chegou minha vez. (...). Ai chegou a médica (....). Fez a prova de toque. Ela enfiou, enfiou, enfiou... que aquela dor horrorosa, que aquilo $\dot{e}$ horroroso. Essa prova de toque é horroroso! (...). Ai chegou mais outra. Ai mais outra, fez a prova de toque. Ai cochichou lá entre eles lá (....). Aí voltou. Ai ela disse 'Você vai lá pra dentro, vai ser uma ce... Você vai lá pra dentro que as outras vão lhe olhar. Ai eu vou...'. Fui. (....) ... ai cheguei noutra sala (....). Ai chegou a médica. Ela me examinou. Ai essa prova de toque foi mais dolorida, porque parece que eu sent... Foi o que deu pra eu entender. Ela falando que deu pra romper a bolsa. Foi o que eu entendi. Que a secreção foi mais maior ainda. (....). Eu disse que não tava mais agüentando de tanto, eu não tava mais suportando, eu pedi pelo Amor de Deus pra eles pararem porque eu não tava mais agüentando, não tava mais suportando. Ai ela pegou, me levou pra uma sala pra escutar o batimento cardíaco do coração... do coração da nenê - que é um aparelho que amarra aqui na cintura e fica escutando - ai ela ficou sentada mais outra galega, que foi a primeira que fez a prova de toque. Ficaram conversando e enquanto isso tavam escutando o coração. O que deu pra eu entender elas falando, entre elas mesmo, que o batimento cardiaco do nenê tava normal, mas elas não entendiam essas dores que eu sentia. Então elas pegou saiu e foram se reunir com outros. Ai eu fiquei lá, uns cinco minutos, sozinha com

\footnotetext{
${ }^{24}$ Mecônio corresponde a uma massa de consistência pastosa e de cor esverdeada, composta por muco, células epiteliais descamadas, bile, pelos de lanugem e vérnix caseosa, coletada do intestino do feto. Constitui a primeira evacuação fecal do recém-nascido. (BLAKISTON. Dicionário Médico. $2^{\text {a }}$ ed. São Paulo, Andrei Editora, 1979).
} 
as dores. Quando pensou que não ela voltou aí - 'Você ainda tá aqui? Não era pra você tá aqui não. 'Ai chamou imediatamente o rapaz pra me levar imediatamente pra sala de cirurgia" [Carmem].

$\mathrm{O}$ estresse vivenciado pela parturiente e a violência do atendimento foram claramente revelados no relato feito por Carmem. O rodizio dos profissionais agentes socialmente legítimos (médicos) - a the tocar o corpo; a insegurança e a indecisão destes, captada por ela nesse momento; a demora para a tomada de decisão; a peregrinação interna - dentro do próprio serviço; a impessoalidade e desrespeito no atendimento. Na modalidade apresentada pelo seu discurso o contexto do hospital não dava espaço a uma interação intercomunicativa, pois, ali não estava um sujeito, mas apenas um corpo, submetido à disciplina da instituição, um corpo capaz apenas de expressar a sua dor. A desqualificação da fala da mulher no ambiente hospitalar não é algo de novo. No espaço de realização da clínica o discurso médico é preponderante sobre qualquer outro. No hospital escola a mulher é usada como recurso de aprendizagem. Como refere TANAKA (1995) "Ela é que tem de pagar com o seu corpo pelo serviço que a instituição pode lhe oferecer. Assim, a conduta acaba sendo mais expectante, mesmo podendo por em risco a vida da paciente" (p.45).

Carmem foi submetida à cesariana feita pela médica de plantão. Ao final, as informações obtidas sobre a sua filha foram as seguintes:

“... de repente chegou a médica, ai chegou e disse assim, 'Mamãe o seu nenê teve que ser levado pra UTI com urgência, porque ela nasceu com o cordão umbilical enrolado no pescoço e engoliu muito um líquido do parto.' Ai eu disse, 'Tá certo'. (....). Ai depois levaram a nenê pra UTI. Aí pronto! Ai eu fiquei no quarto, adormeci"'[Carmem].

As impressões de Carmem ao visitar a filha na UTI. 
"No outro dia, já seguinte, no domingo. Ai eu fui, na hora da visita. Eu fui vê a nenê. Olhei ela. O rapaz disse que ela tava muito grave, que ela tava cheia de... Um bocado de aparelhinho, uns canudinhos nela, assim... Eu olhei pra ela, peguei um pouquinho na mãozinha dela... Ela tava com a corzinha... meio assim, como escurinha. Muito bonitinha ela. Perfeitinha. Ai eu voltei. disse a minha mãe. Ela era muito parecida com o meu pai. E me sentei e minha mãe disse, 'É, vamos ter calma. Pode ser que ela consiga, né. Vamos rezar pra Deus. "' [Carmem]

As palavras de conforto da mãe e a esperança de um milagre foram o possível de ser esperado naquele momento. Ao mesmo tempo, internamente ela parecia vislumbrar a ameaça que rondava a vida da sua filha.

“... pensei assim, com meus botões mesmo, eu disse assim, 'Mas ela não chorou na hora de nascer, que todo nenê chora quando nasce. ' $O$ meu não chorou. Lá no fundo, no fundo, dentro de mim, eu senti que ela não... não ia escapar. Porque ela... Eu sempre escutei que todas nenê quando nasce, chora. Ela não chorou. Tava lá na UTI com os olhinhos fechados, tudo direitinho. Só o coraçãozinho dela que batia. Ai depois a... Eu fui visitar de novo. Aí, a moça lá, a médica especialista tava lá e disse que era muito grave. Que eu me preparasse que ela não podia resistir, e que eu começasse a me preparar, porque ela não tava rosadinha, ela tava escurinha e ela só respirava pelo aparelho. (....). Como foi de noite, ai chegou uma enfermeira me chamando pra mim ir lá. Ai me deu a notícia que ela tinha falecido. Eu ainda olhei lá pra ela. Eu não chorei porque fiquei parada, olhando pra ela. As médica falando. Uma... uma parte de mim não acreditava. Eu ainda achava que ela tava viva, que tinha algum engano. Mas, eu olhava pra ela e disse, 'Não! É todinha parecida comigo, com meu pai, não pode ser engano. Não! Não foi trocada. É ela mesma. "' [Carmem].

A esperança de um engano, o desejo de que tivesse havido troca, o milagre que não veio, pôs fim ao seu sonho naquele momento. O sonho de uma mulher, jovem, que fez o seu pré-natal com regularidade, que segundo ela fazia ultra-sonografia sempre que podia "porque gostava de vê a nenê" e que ia ser mãe pela primeira vez. 


\section{- $O$ caso de Neide:}

Neide foi instruída pela médica que acompanhou o seu pré-natal para: "Qualquer... Qualquer coisa, você venha à procura da, da, da emergência aqui da Maternidade A. Eu fiz assim”.

Ela entrou em trabalho de parto na madrugada da terça-feira e procurou o serviço de saúde. O serviço procurado foi o PA da Maternidade A que ela havia feito o pré-natal.

\section{Serviço de Saúde A [1]}

"Tinha uma médica, doutora $A$, no atendimento, (....). Ela não examinou a minha barriga. Mas eu falei que eu sangrei muito. Ela só fez... Ela só fez é..., dá o toque. Aí ela falou bem assim pra mim, 'Você não vai ter parto agora, isso é marinheiro de primeira viagem.' (....). Então, ela disse: 'Você volte pra casa, e você só venha aqui quando tiver no... e nem volte aqui, você vá pro Hospital $C$ '. Eu disse: 'A senhora vai me dar um encaminhamento pra eles me atenderem lá?' - 'Não, porque quando vem de lá a gente atende aqui'. Só que lá existe um protocolo. Se lá não fez..., não fez acompanhamento lá eles não atendem". [Neide]

Começa aqui a peregrinação de Neide. Trata-se de uma outra modalidade, denominada por TANAKA (1995) de "peregrinação por recusa". Nesse caso não há deteç̧ão da gravidade do caso e a parturiente é descartada.

Quando chegou ao serviço de saúde ela tinha como queixas "dor de cabeça" e "sangramento". Essas queixas não configurariam riscos na gravidez e, por conseguinte, não denotaria a necessidade de uma maior atenção à gestante? De acordo com a sua narrativa, a avaliação clínica realizada pela médica, restrita ao toque vaginal, definiu que o parto ainda iria demorar. E isso, por si só, justificou o descarte. Não foi dada a devida importância às queixas trazidas por ela, tampouco o fato dela ter realizado o pré-natal naquela instituição. Ao nosso ver a atenção médica, 
no que se refere à clínica, nesse caso foi negligenciada. $O$ feto sequer foi monitorado, segundo o seu relato.

No contexto da assistência à saúde da mulher TANAKA (1995) também chama atenção para a importância da "oportunidade da atenção médica" - implicada no valor da clínica e do manejo do parto. Segundo a autora, este aspecto esteve presente na maior parte dos óbitos maternos por ela estudada, chegando inclusive a anular os beneficios da assistência pré-natal. Por isso, “É premente que ocorra o resgate da clinica para que ela volte a ter um papel efetivo na assistência a saúde" (TANAKA 1995 p.13).

No que toca ao descaso com a gestante MINAYO (1994) levanta a seguinte questão:

“... é apenas agora, com a crise do repasse de verbas, que o 'descaso' com as gestantes se instalou ou há uma circularidade perversa entre a qualidade de serviços prestados, a pobreza das mulheres e a dificuldade delas em se organizar e exigir respeito dos serviços públicos. Por não se constituirem num 'sujeito coletivo' e sim em usuárias individuais do sistema, as futuras mães sofrem, sobretudo os reflexos de uma politica de 'insegurança social"'.

Interessante notar no depoimento de Neide a sua tentativa individual de reação, uma atitude mais reivindicativa, em comparação aos dois casos anteriores.

Na tarde do mesmo dia Neide procurou o serviço de saúde para o qual havia sido encaminhada. Ao chegar no hospital também houve recusa ao seu atendimento.

\section{Serviço de Saúde C [2]}

"Os médicos de lá disse: 'Não, eu não posso atender porque eu não procedi, não foi eu que acompanhei. Eu não sei como é que tá sua criança. $O$ que acontecer eu vou ser responsável.' Ai uma pessoa que tava me 
acompanhando... Ela disse, 'Agora você fica lá ou por bem ou por mal. 'Ai quando eu dei entrada aqui..." [Neide]

As reflexões sobre a tarefa assistencial conduzem ao campo ético, afirma MARTINS (2002). Para a autora, essa questão surge quando alguém se preocupa com as conseqüências que sua conduta tem sobre o outro. Para que haja ética, é preciso ver (perceber) o outro.

Ao que se pode notar a fragilidade desse campo no âmbito das relações institucionais de saúde é bastante grande.

Sem ter sido admitida Neide retorna ao Serviço de Saúde A [3], onde foi atendida por um outro profissional que estava de plantão.

\section{Serviço de Saúde A [3]}

"Então, quando eu cheguei aqui, à tarde, ai ela veio comigo, eu entrei, o médico que tava foi um excelente médico, já foi uma pessoa que me deu bastante atenção, perguntou quem foi a médica, ai eu falei tudo como aconteceu. Ele perguntou, 'Quem foi a médica?' Ai eu disse, 'Foi Dra. A.' Ai a enfermeira ela começou a me examinar e a minha criança... Ai ela... ai a primeira coisa que elas fizeram... elas perguntaram, 'Quando você deu entrada, pela madrugada, alguém exami... examin... Examinou a..., a sua barriga? Eu disse 'Não examinou minha barriga. Ela só deu um toque e falou que isso era normal, e eu voltasse pra casa.' Eu disse, 'Mas doutora eu já entrei em estado de parto e sangrando, porque isso não é normal. ' 'Mas aqui não tem, não tem lugar pra você. E não venha pra cá, vá pro Hospital $C$, porque aqui não tem lugar pra você.' Primeiro ela começou errando porque eu..., pelo meu entendimento, eu..., onde foi que eu fiz meu pré-natal? Toda assistência foi aqui, e no último momento que a gente... Que eu precisei, não foi assim. (....). ... Ele me examinou, não escutou a criança e foi... De último momento ele bateu uma ultra. Quando ele bateu, a criança não tava mais com vida. Ai, me internaram. Mas, tudo mudou nesse... A partir desse momento" [Neide].

Nos trechos da fala de Neide fica patente a diferenciação nas atitudes dos profissionais pertencentes à mesma instituição. O que estaria demarcando essa 
diferença? O relato de Neide nos remete a reflexão sobre um provável despreparo técnico e a indisponibilidade para acolhimento da paciente em sua integralidade e continência aos seus aspectos emocionais.

Segundo MARTINS (2001), o trabalho de um profissional, qualquer que seja a sua atividade, depende tanto da qualidade técnica como da qualidade interacional e, nesse sentido, muitas queixa e problemas apresentados pelos usuários podem ser resolvidos ou atenuados quando estes se sentem compreendidos e respeitados pelos profissionais.

Neide teve seu parto realizado na Maternidade $\mathrm{A}$, pelo médico de plantão. $\mathrm{O}$ seu bebê pesou 3.700 gramas. Inicialmente foi tentada a indução do parto, mas este não evoluiu. Teve o seu parto por via vaginal e foi utilizado fórceps para ajudar na retirada do feto. Neide foi internada na terça-feira às quinze horas e o parto foi concluido na quarta-feira às quatro horas da manhã.

A partir dessas observações, o que poderíamos pensar acerca da morte do filho de Neide? Será que esta morte poderia ou não ter sido evitada? Neide fez o seu prénatal desde o início da gestação, regularmente, sem relato de complicação na gravidez. Ia ter o seu primeiro filho.

LEITE e col. (1997) citando SCHWARCZ e col. (1984) refere que natimortos com peso igual ou superior a 2500 gramas coloca em questão a qualidade da atenção pré-natal, além do que sugere dificuldade na identificação do risco numa etapa da gestação que pressupunha que o concepto seria viável. Mortes ocorridas durante o trabalho de parto sugerem que as suas condições clínicas já eram insatisfatórias na ocasião ou o manejo obstétrico foi inadequado. 


\section{- Os casos de Ivani, Dalva, Franca e Liana:}

A ausência de retaguarda hospitalar no momento do parto também esteve presente nos casos de Ivani, Dalva, Franca e Liana. Essa problemática foi apontada por TANAKA (1995) por referência a mulheres que fazem o pré-natal e são atendidas pelo sistema público de saúde.

De acordo com a autora a peregrinação tornou-se tão comum em nosso meio que nem sempre o paciente se revolta quando não obtém assistência. Ela se conforma e parte em busca de outra instituição. Porém tem consciência de que isso não está certo.

Ivani procurou o serviço de saúde por causa das contrações e do aparecimento de sangramento. Não foi admitida no primeiro hospital por falta de vaga e de infraestrutura para atendimento do seu caso, "A menina disse que o nenê tava sentado, lá na maternidade (....). Ai disse que eu não podia ficar lá porque não tinha cama". Foi encaminhada para outro serviço onde foi realizado o parto.

O parto de Ivani foi normal e foi realizado por plantonista. Sobre as condições de nascimento e as informações do recém-nascido ela mencionou ter ouvido o choro da criança ao nascer, porém era um choro fraco: "Só um pouquinho e muito tempo. Passou um tempinho. Um chorinho bem fraquinho" [Ivani].

Como a criança nasceu com problemas respiratórios, precisou ser transferida para outro hospital que tivesse UTI neonatal. Por falta de vaga em UTI a criança também teve que aguardar para ser transferida. Nesse caso a peregrinação é também do filho.

Ivani viu o seu filho apenas no momento do parto. As informações obtidas sobre a transferência e morte do filho foram descritas por ela da seguinte forma: 
"Ai, a depois foi que ela disse, 'O menino já foi pra outo hospital.' Eu digo, 'Então tá certo.' E tombém da cama não sai. Nem veio mais ninguém me dizer mais nada. Ai acabou-se. Passou o resto do dia todinho. E tudo bem. Eu tombém num perguntei. Nem elas me disseram mais nem nada. Ai no outo dia foi que elas disseram, 'Seu menino não tá aqui. Seu menino tá no outo hospital e tá bem.' Até disseram... Falaram assim, 'Tá bem.' Eu digo, 'Tá certo.' Ai, quando foi no fim minha menina... Minha irmã veio com a minha menina e disse que o menino não resistiu, morreu". [Ivani].

Este seria o décimo quarto filho de Ivani. Em relação à gravidez atual ela apresentou algumas intercorrências, porém vinha sendo acompanhada no pré-natal. Na sua história não há relato de perdas anteriores de filho.

Dalva teve o seu trabalho de parto antes da data prevista. As contrações tiveram início faltavam quinze dias para completar os nove meses de gestação. Nesse período procurou a Maternidade F, local em que havia realizado o seu pré-natal. Ao chegar na maternidade foi examinada e orientada para voltar pra casa, pois ainda não estava na hora do bebê nascer. Recebeu instruções sobre como deveria controlar as contrações uterinas em casa. Foi também orientada para no momento de ter o filho procurar a Maternidade A. Com o aumento das contrações procurou o serviço que fora recomendado. O seu relato sobre a morte e o nascimento é o que se segue:

"Ai quando chegou... Eu vi que tava sentindo mesmo aquelas dor... (....). Ai minha irmã disse: 'Não Dalva, a gente vai levar você lá na Maternidade A.' (...). Ai a turma da enfermagem né, disseram: 'Você vai ficar aqui, você não vai sofrer nada.' Eu disse: 'Tá certo.' Mas não disseram que o menino tinha... tava morto né? Quando eu subi disse: 'Não, a gente vai bater a última... ultra. Eu disse: 'Tudo bem!' Ai quando eu subi, que eles... Ai eles disse... mostraram assim... 'Dalva, seu fio (sic) tá morto.' (....). " [Dalva].

Dalva teve o filho natimorto e ela só veio ser informada da morte durante o trabalho de parto. Interessante a observação feita por ela sobre a maneira com a equipe de saúde se referiu ao nascimento do seu filho. 
"Então quando en... ( Oue eles disseram: 'Dalva vai sair... Seu filho vai sair agora.' Não foi nem nascer. Iisseram: 'Vai sair agora' Nascer não que ele já tava morto. 'Iaça força. Iraça força. Bote pensamento positivo que a gente vai conseguir.' Ai quando eu fiz aquele pensamento positivo que eles me ajudaram ai a criança... Ai colocaram assim perto de mim uns dez mimutos ainda. É eu lá vendo. Mas tava tão passada que eu não senti. Vim sentir depois". [Dalva].

Dalva teve o seu parto vaginal realizado pelo plantonista. Mencionou a dor sofrida pela perda, não obstante mostrou-se conformada.

Franca mencionou que logo que surgiram as contrações ela procurou o pronto atendimento do Hospital C. Ao ser atendida pela plantonista esta não conseguiu auscultar os batimentos cardiacos do feto.

"Ai ela chamou o outro médico que tava... fazendo até um parto. Ai ele veio, trouxe o aparelho dele. Foi buscar o parelho lá no carro dele... Ai me es..., escutou ai disse que não tava escutando não. Ai viesse pra'qui, para maternidade porque tinha um aparelho melhor de escutar e se fosse um caso de uma cirurgia fazia, né?". [Franca]

A fala de Franca deixa transparecer a pouca estrutura do hospital para realizar o seu atendimento. Tal situação pode ser considerada como geradora de risco perinatal. $\mathrm{Na}$ falta de equipamentos para monitorização fetal, o médico teve que recorrer ao seu próprio instrumento para exame. Encaminhada para a Maternidade A ela foi atendida pela plantonista. Sendo confirmada a morte fetal Franca foi admitida para a realização do parto. Assim como Ivani e Dalva ela teve o seu parto por via vaginal.

Liana ao perceber que estava em trabalho de parto procurou o Serviço B [1] Tinha contrações. Ao chegar ao hospital foi encaminhada para o repouso, pois deveria ficar em observação. Ela não ficou. Ela preferiu ir para a Maternidade A. A justificativa para não ser internada no primeiro serviço de saúde que havia procurado 
foi o de que sentiu medo. Disse ela: "Tive. Tive tanto que vim embora... (....). Ainda tenho até a guia de internamento de lá. Vim embora. É porque éu confiava muito na Maternidade A porque en tive as minhas filhas..." [Liana]

Ela fala sobre a impressão do atendimento no Serviço de Saude B [1]

"No Hospital B e'u não gostei do atendimento". (....). Porque quando eu cheguei pra ser examinada, ia chegando uma paciente naquelas cadeiras né, naquela cadeira dé roda, já com o nené saindo. É a qué tava de plantão, não sei se era enfermeira ou se médica, sei que ela que fez meu exame, fez o toque. Ela chamou a mulher de nojenta. (....). A que tava tendo a nené. Porque ela sujou, disse assim, 'Essa nojenta.' E onde ela me colocou pra me fazer... pra me deitar pra fazer o exame estava sujo. E onde ela desenrolou o pano assim, pra cortar o embigo (sic) do menino, eu vi. Não, não gostei do atendimento de lá. Não gostei de lá realmente". [Liana].

A violência institucional aparece em toda intensidade na narrativa trazida por Liana, dando visibilidade a um extenso processo de desumanização da assistência. Liana teve o seu parto realizado na Maternidade A. Ao chegar foi encaminhada de imediato para o centro cirúrgico. A criança foi retirada já sem vida. Liana recusou-se a vê-la.

Dos quatro relatos de morte perinatal que apresentamos em conjunto, apenas o caso de Ivani correspondeu à morte neonatal precoce. Os três outros casos trataramse de mortes fetais. Estes sugerem dificuldade na identificação do risco a que estiveram submetidas estas mulheres em um período próximo a viabilidade do concepto e o real impacto da assistência recebida na saúde da gestante. Nesse sentido, torna-se necessário questionar a qualidade do serviço pré-natal. Uma outra possibilidade relaciona-se ao fenômeno denominado por Tanaka (1995) de "alta do pré-natal", em que a mulher grávida ao se aproximar do período do parto, não tem garantido o seu encaminhamento para maternidade de referência. 


\section{- O caso de Cristina:}

Esse é um caso em que a paciente não passou pelo processo de peregrinação $\mathrm{Na}$ sua história encontam-se implicadas outras questões relacionadas à assistência a mulher no momento do parto. Impõe-se nesse caso fundamentalmente a problemática da avaliação clínica e da relação médico-paciente. Não que nos casos anteriores essa problemática estivesse ausente, mas no caso específico de Cristina esses aspectos se revelaram de forma mais gritante.

Cristina estava com nove meses completos de gravidez quando teve iniciadas as contrações uterina. Procurou o serviço de plantão do Hospital C. A razão de ter procurado este serviço foi para ser atendida pela médica que fez o seu acompanhamento no pré-natal. A sua história ela descreve da seguinte maneira.

"Ai eu cheguei lá, doutora $V$. não estava, tava o plantonista. Ai ele fez o toque em mim e disse que eu estava com quatro centimetros, que iria telefonar pra ela. Então, eu comecei a sentir só aquelas cólicas normais, né, quer dizer, pra mim né, que era a primeira vez, eu achava que era normal. (....). Ai ela pediu pra ele fazer outro toque em mim. Ele fez, eu tava com sete centimetros e minha bolsa ainda não tinha estonurado. Então ele estourou a bolsa" [Cristina].

Com a chegada da médica ao hospital Cristina passa a ser acompanhada por ela. Gostariamos de preservar o seu relato tendo em vista a sua importância na compreensão dos nossos argumentos.

“Então ela disse, 'Cristina eu vou fazer outro toque em você.' Fez outro toque. Eu tava com nove centimetros. Então, ela me levou pra, pra sala de parto, me botou na posição e disse que eu contimuasse fazendo força. Então, eu comecei... Ela pegou e aplicou o soro. Depois que ela aplicou o soro, eu comecei a ter ânsia de vômito, querer vomitar. Ai ela disse que isso era normal, tanto ela como uma menina que tava ajudando a ela, né. Ai, eu comecei vomitar. Vomitei. Então, com isso eu perdi força, pra botar o bebê pra fora, né. Mas ela disse, 'Não Cristina, você tem que ter essa criança 
normal.' Ela disse, 'Eu não vou fazer parto cesárea em você.' Porque eu comecei a pedir, que ela fizesse um parto cesárea em mim. E, é... eu olhei, tinha um relógio mesmo na frente. Isso já era o quê? quase meia noite. Então ela pediu pra eu ficar fazendo força, fazendo força, e eu fazia. Só, que ela ficava fazendo o toque né, pra fazer... que a criança saisse né, ai ela disse que a cabecinha dele já tava saindo, que eu fizesse mais força. Só que eu não tinha mais força. Comecei a ter falta de ar, ficar tonta. Não vinha o ar pra cima... pra mim, e eu não conseguia fazer força. Mas ela dizendo que eu fizesse força, que era pra criança sair. Foi ai que veio o plantonista né, ai ela pediu pra que ele fizesse força na minha barriga, que eu não tava tendo força pra botar ele pra fora. Ai, ele encarcou né, e nada de eu conseguir. Ai ele perguntou: 'O que você tá sentindo?' $E u$ fiz: 'Eu tô sentindo falta de ar. Não tô conseguindo respirar.' Ai, foi ai que ele disse: ' $V$. tem que fazer uma cesárea urgente nessa menina '" [Cristina].

Teoricamente Cristina tinha tudo para que o seu parto corresse com tranqüilidade. $O$ trabalho de parto aparentemente aconteceu como esperado. Diferentemente das outras mulheres não passou pelo processo de procura de um local para ter o seu filho. Estava acompanhada da médica que fez o seu pré-natal, portanto alguém que conhecia o percurso da sua gravidez e que havia monitorado o bebê. Com ela Cristina sentia-se segura.

Grávida do seu primeiro filho, jovem, não apresentou nenhuma intercorrência na gestação que pudesse sinalizar algum tipo de risco para ela nem para o feto.

Que fatores poderiam então ser pensados que pudesse desencadear tão brutal desfecho?

Ao nosso ver faltou uma avaliação clínica criteriosa sobre o caso. A expectativa médica de realizar o parto por via vaginal impôs a mulher o sacrificio do seu filho. Essa foi uma outra via da violência detectada na assistência a mulher.

A ausência de escuta aos seus apelos. Cristina manifestou a impossibilidade de ter o seu filho por via vaginal. Ela percebeu a gravidade do seu estado e sinalizou, expressou, gritou. mas não foi ouvida. Os médicos estavam surdos à fala da paciente. 
A singularidade do indivíduo foi totalmente desrespeitada no seu caso, a voz da paciente não foi considerada.

Cristina foi violentada no momento em que mais precisava de apoio, segurança, atenção, amparo. Nesse instante ela parecia estar só.

Segundo TANAKA (1995), "O profissional de saúde tem dificuldade de ouvir o paciente, tomando atitudes incorretas". Este parece que foi um desses casos.

A dificuldade de ouvir os apelos da mulher foi patente, porém, em que se apoiavam os profissionais para prolongar tanto a tomada de uma outra decisão? Certamente a clínica não foi soberana nesse caso, não deu a direção. Percebeu-se total ausência de interpretação correta e adequada. $O$ caso, aparentemente, foi agravado pela obsessão por parto normal em detrimento da necessidade de uma cesárea.

Nesse sentido, não caberia para o seu caso a decisão de um parto cirúrgico? Isso só foi percebido tardiamente. Ao que parece faltou o controle rígido do trabalho de parto, a detecção precoce do risco fetal e uma tomada de decisão mais satisfatória para a mãe e para o bebê. Nada disso parece ter sido feito. Sendo assim, o sofrimento fetal foi inevitável e a criança nasceu em estado grave, vindo a falecer quarenta e oito horas depois.

Com a tendência à realização do parto normal em detrimento da cesariana perdeu-se a clínica e a relação médico-paciente nesse caso. Não se trata de recomendar indiscriminadamente a realização da cirurgia, mas da avaliação criteriosa da sua necessidade.

Cristina não presenciou o nascimento do filho, não sabe dizer se ele chorou ou não após o nascimento. Após a cesárea, tardiamente decidida, a médica colocou 
sobre ela a responsabilidade pela não evolução normal do parto em razão dela não ter feito força para a criança nascer. Ela relata:

"Ai, foi aí que eu apaguei. Não vi mais nada. Quando eu retornei, vi alguma coisa, já tava com um pano verde na minha frente, com (inaudivel) no meu dedo, e outras pessoas né. Eu tava dormente, pra baixo. Não tava sentindo nada. Ai adormeci de novo. Quando eu retornei, V. perguntando se eu tava bem, se eu tava sentindo alguma coisa, foi ai que ela me informou: 'Olhe Cristina, seu bebê... ele nasceu é..., enrolado com a trompa... né?' $O$ cordão umbilical no pescoço, e nasceu muito fraquinho. Ele passou da hora, porque você não tava tendo força. Você passou da hora, então por isso ele nasceu... ele não tava saindo. E também porque ele tava enrolado no pescoço. Ele foi direto pra incubadora. Por isso você não viu, e ele nem vai ficar com você. Ai me levaram pra sala né, pra eu ficar em repouso". [Cristina].

A percepção de Cristina sobre a atitude dos profissionais que a assitiram no parto foi a seguinte:

"Eles conversavam entre si. Ai agora, na hora que eu dizia assim, que eu tava sem força, é que eles davam atenção, né. Mas eles ficavam conversando sobre um assunto de outra pessoa, de outro médico. Ai, na hora que eu sentia falta de ar eu chamava, eu dizia... eu chamava pela médica. Ai ela fazia: 'Mulher faça força, deixe disso, faça força, senão ele não nasce.' Ai eu ficava dizendo 'Não, mas eu tô com falta de ar. Eu tô sem força.' Ela fazia: 'Não. Faça força. Faça força senão ele não nasce.' Mas, era só quando eu chamava atenção, que eles vinham pra mim”. [Cristina].

Do rompimento da bolsa até a decisão de fazer cesárea decorreram aproximadamente três horas na tentativa para que o parto fosse vaginal. Segundo Cristina durante esse período foi realizada a episiotomia, porém os batimentos cardíacos do feto, em nenhum momento, foram monitorados. Cristina refere que durante o parto apresentava fortes contrações, mas apesar disso não houve a expulsão do feto. 
A discussão proposta para essa narrativa não inclui o julgamento de valor de certo ou errado, mas a possibilidade de refletir sobre os aspectos éticos que esse caso suscita

Vale ainda comentar sobre uma outra violência imposta sobre Cristina, a inexistência de franqueza, de sinceridade por parte dos profissionais de saúde e da própria familia. Sendo assim, a ela foi negado também o direito de ver o filho enquanto estava doente e de ser informada sobre a sua morte, a qual ela só veio ter conhecimento após o sepultamento.

\section{- O caso de Maria:}

Maria tinha uma situação diferenciada em relação às demais mulheres que participaram desse estudo. Nesse sentido ela também não foi submetida à peregrinação para obtenção de atendimento ao parto. Ela diz:

"Eu tenho um plano de saude, que é a da Hapevida. Ai eu fui fazer a ultrasonografia lá no Hospital $G$, né. Então, o médico de lá já fez a ultrasonografia que foi diagnosticado... Fle entrou logo em contato com a médica. A partir dai, ela disse que eu fizesse já o internamento, não saisse de lá... eu fizesse o internamento pra ficar no proprio hospital pra ela fazer a cinurgia. Ai foi vê, o centro cirirgico tava ocupado, e o anestesista num..., lava com... em outra cirurgia, lá mesmo no bloco cirúrgico do hospital..., e que só estaria a ... pronto uma das salas as catorze horas. Ai pronto. Ai foi... ela entrou em contato com outro auxiliar dela, outro médico auxiliar e..., ai nesse meio tem..., nesse intervalo de tempo... Foi o tempo que a gente usou pra avisar ao pessoal da familia, né; as pessoas mais chegadas a familia e fazer o internamento, exames, os pré-operatórios de praxe e..., me internei, fiquei lá mesmo..., dois dias depois en fui Embora". [Maria].

Maria teve parto cesariano. A morte do bebê foi intra-útero. Ela não presenciou o momento do nascimento do bebê. $\mathrm{O}$ parto foi realizado pela médica que fez o seu 
pré-natal. Sobre o parto ela relata: "Eu soube de manhã e o parto foi à tarde".

[Maria]

As informações sobre o filho nascido morto foram obtidas posteriormente:

“A se..., a senhora teve um bebê...' Eu disse: 'Foi. Cadê o..., o feto?' Ela disse 'Já desceu.' Ele deve ter ido pra o necrotério, né? Eu deduzi assim. Tá certo. Também não perguntei. Ai ela disse..., ai ela disse assim: 'Olhe Maria, está.... está..., a única coisa que eu diagnostiquei logo que eu abri foi o nó no cordão, o nó verdadeiro, e duas circular de cordão. 'Ai disse, 'Inclusive o cordão era muito grande, tinha cerca de oitenta centímetros. "' [Maria]

Sendo Maria enfermeira e detentora de todo um discurso técnico ela se expressa da seguinte forma:

"Bom. pelo fato da criança mexer muito, né, vários colegas obstetras, que eu já conversei assim, esporadicamente, eles atribuem a criança em alta atividade né, ela pode ter se enrolado no cordão, devido a minha atividade intensa, e esse cordão foi, à medida que a criança foi pegando mais peso, crescendo, mais pro final da gravidez, então esse cordão pode ter ido diminuindo a nutrição do feto e ter provocado essa morte intra-uterina da criança" [Maria]

Já a médica que a atendeu não teve explicações para o acontecimento, apenas surpresa pelo inesperado.

"Então ela ficou realmente..., ela disse: 'Eu não sei como foi que isso aconteceu..., que a gente vinha tudo tão bem!' Foi uma..., Realmente foi uma surpresa pra ela, porque as minhas gravidez anterior que ela acompanhou não teve problema nenhum, nem no pré-natal, nem no parto, o puerpério assim, maravilhoso, não tive problema nenhum. E ela ficou, realmente, bastante surpresa, com tudo o que aconteceu." [Maria]

Ao término desse capítulo gostaríamos de retomar MINAYO (1994) através da seguinte passagem: "Parece haver uma associação entre uma práxis institucional 
marcada pela violência e pelo descaso; uma práxis profissional médica empobrecida por vários motivos, entre eles a falta de visão e experiência multiprofissional; e as atitudes e comportamentos de pouca reivindicação das mulheres por mais quantidade e qualidade da atenção pré-natal", na qual eu acrescentaria a inclusão das instâncias do cuidado no pré-parto, no parto e puerpério.

O que se opõe ao descuido e ao descaso é o cuidado. Cuidar é mais que um ato; é uma atitude. Portanto, abrange mais que um momento de atenção, de zelo e de desvelo. Representa uma atitude de ocupação, preocupação, de responsabilização e de envolvimento afetivo com o outro (BOFF 1999). 


\section{Percepção materna da perda perinatal}

Quais noções aparecem no relato da experiência dos atores envolvidos, relativamente à perda, por morte, do filho? Qual a percepção do acontecimento e interpretação dada acerca da mencionada experiência? Em que direção está focalizado o olhar materno, diante da experiência da morte? Como a noção de evitabilidade da morte aparece no discurso sobre a perda? Em que situação (circunstância) ela surge na história de perda perinatal?

\subsection{A explicação materna da perda}

Convém relembrar que os casos de Íris, Ivani, Carmem e Cristina, apresentados a seguir, se referem a mortes ocorridas após o nascimento.

Num primeiro momento, referindo-se ao que poderia ter causado a morte do seu filho Íris diz: "(....). eu acho que foi de raiva, né. Que eu tive muita raiva". Ela se refere aos momentos de raiva que teve do marido durante a gravidez. Logo em seguida, ela reconsidera a sua afirmativa apoiando-se na opinião de terceiros, e assevera: "Mas ai, outras pessoas dizem que não. Dizem que foi por causa da hora. Que ele passou da hora de nascer". Essa última opinião Íris assume em outros momentos da sua narrativa:

"Eu acho que foi porque passou do tempo de nascer. Eu acho assim que foi por isso. Que passou muito da hora dele nascer. (....). Eu comecei sofrer no domingo e na segunda vim ter ele de duas e quarenta e cinco da tarde. (....). E eu com dor. Morrendo de dor e eles aqui só fazia examinar e dizia que 
dizia que não tava perto. Ai o que eu acho é isso que passou do tempo dele nascer.(...). Eu não acho assim, que ele nasceu com problema do coração. Eu acho que esse cansaço... Esse negócio que ele ficou todo... assim, patacado, preto, acho que foi do tempo, que passou do tempo [Íris].

A responsabilidade por haver passado do tempo do nascimento da criança ela atribui à atitude da equipe de saúde, que, segundo ela,

“... me examinavam e diziam que não tava na hora do menino nascer. (....). Eles diziam que não tava na hora, que... Isso foi enrolando, enrolando, ai ao invés de ter me deixado aqui, me mandaram pra outro hospital. Por isso que acho assim, que foi culpa deles dele ter passado da hora de nascer" [Íris].

Íris critica o procedimento clinico adotado, identifica como erro à decisão de encaminhá-la para outro serviço. A peregrinação se configura aqui como risco institucional.

Nesse momento torna-se importante considerar as noções de confiança e risco discutidas por GIDDENS (1991), para quem tais noções são tidas como produtos específicos da modernidade e são considerados elementos essenciais de sistemas peritos. $^{25}$ De acordo com o autor, enquanto leigos nossa relação com esses sistemas ou com os profissionais que nele estão integrados, sempre envolve a fé no conhecimento perito que aplicam, já que não podemos conferi-lo exaustivamente. Não obstante, como se pôde notar através da fala de Íris, na relação travada com o profissional de saúde a esperada relação de confiança não se constituiu.

\footnotetext{
${ }^{25}$ Os sistemas peritos são sistemas de excelência técnica ou competência profissional que organizam grandes áreas dos ambientes material e social em que vivemos hoje. Integra os sistemas peritos profissionais - advogados, arquitetos, médicos, etc. (GIDDENS A. As conseqüências da modernidade. São Paulo, Editora UNESP, 1991).
} 
Íris também atribui responsabilidade pela doença do filho a seu hábito de fumar, expressando-se da seguinte forma: "E o cansaço eu acho que era dele mesmo. Porque eu fumava quando eu tava grávida". Em outra ocasião, vislumbra a possibilidade de ser, ela mesma, responsável pela morte do filho. Nessa circunstância específica ela atribui o acontecimento a um castigo divino, por ela ter reclamado, algumas vezes, dos incômodos da gravidez:

"Agora eu reclamava, quando eu ia dormir. Eu dizia: 'Ah meu Deus do céu é muito ruim a pessoa ficar com o barrigão porque só pode dormir de banda. de banda e de banda.' Só falava isso. Ai Zé disse: 'Você ainda quer engravidar de novo?' Eu dizia: 'Eu não.' Eu acho que Deus me castigou por isso, porque eu dizia que não queria mais engravidar" [Íris].

A auto-responsabilização pela morte do filho constitui uma modalidade de culpabilização que tem como conotação à idéia de castigo.

Assim como Íris, Carmem respalda a sua explicação sobre a morte do filho na justificativa apresentada por terceiros. Ela questiona o procedimento médico adotado, tanto no que diz respeito ao tipo de parto, quanto à demora para uma intervenção mais efetiva e que poupasse a vida do seu filho.

"Minha mãe acha e diz que passou da hora. Passou da hora e foi erro médico. Se os médico tivesse mais prestado atenção, viu que tava passando da hora tinha feito logo. Negócio de esperar parto normal, que ela acha que hoje em dia os médico tão fazendo mais parto normal do que cesárea, porque o cesáreo tá de graça. E, sei lá, o que manda mais... O Ministro da Saúde fez essa campanha agora de todo mundo ter parto normal ai os médico tão mais prestando atenção nos parto normal do que nos cesáreo. Minha mãe acha isso. Que se ajuntasse todas mulher e reclamasse com ele... Que ele é o grande culpado, não os médico. Minha mãe acha isso. Que tem muita criança morrendo por causo disso". [Carmem]. 
Também Carmem em sua narrativa faz uma avaliação sobre o procedimento médico adotado. Aqui mais uma vez a clínica é questionada. Repete-se a crítica feita anteriormente pela demora na tomada de decisão e pela escolha da expectação, para que ela tivesse o seu parto normal. Carmem amplia a sua crítica a política de saúde adotada, que segundo ela tende a generalização dos indivíduos. Além disso, na sua percepção houve erro médico decorrente da falta de atenção no atendimento. No cumprimento da norma instituída, sem critério de diferenciação entre os indivíduos, as diferenças são negadas e as impossibilidades das pessoas não são consideradas.

Ao proceder a uma releitura do risco da morte perinatal não se pode prescindir da percepção materna a cerca da sua experiência relativamente ao processo da gravidez e possíveis riscos que emergem da sua compreensão, por exemplo, que nem todas as mulheres são iguais, que tem sua especificidade, e que nem todas estão aptas em responder igualmente do ponto de vista da fisiologia do parto.

Carmem (re) traduz o discurso técnico acerca da gravidade da situação, relativamente à idade gestacional da seguinte forma:

“Eu, eu entendi ela dizendo assim, 'Você vá agora pra Maternidade. (....). Mas, eu entendi ela dizendo assim, 'Sua nenê já tá no limite já. E vá pra Maternidade. (....). Vou fazer as contas já pra ele não ter trabalho.' Ela disse assim. (......Ai eu entendi ela dizendo assim, 'Seu nenê já tá no limite". [Carmem].

Num dado momento, o componente religioso toma lugar no discurso de Carmem, como um mecanismo utilizado para enfrentamento e aceitação da perda. Nesse sentido ela se expressa: "Não foi não culpa sua, não foi culpa minha, foi Deus que quis assim...' [falando ao marido]. Eu butei isso na minha cabeça, que foi Deus que quis, porque ele... Não houve... Pra mim não teve erro...". 
Atribuir a responsabilidade à vontade divina configura uma outra modalidade de responsabilização pela morte do filho. Ao que nos pareceu, esta é a única forma aceitável pela maior parte das mulheres, tipo: "Deus dá, Deus tira".

Em seguida Carmem contrapõe o tom da colocação anterior e o seu discurso assume uma outra feição, na qual reconhece erro na conduta médica, relacionada com a demora em realizar cesárea e por não levar em consideração da sua história familiar de partos. Nesse sentido ela identifica o risco institucional e manifesta a inexistência de confiança na capacidade do profissional.

“... Ou teve erro. Porque eu acho que se os médico tivesse agido mais rápido, eu acho que eu estava com ela. Se eles não tivesse esperado tanto pra ser parto normal. Porque a minha mãe não teve parto normal. Minha irmã não teve parto normal. Ninguém da minha familia teve parto normal. É mais cesárea. (....). Eu acredito numa coisa que... Agora querem porque querem que todo mundo tenha parto normal. Os médico tão mais em cima dos parto normal do que nos cesárea. Eles não presta atenção. Nem toda mulher vai ter parto normal". [Carmem].

Além dos aspectos já comentados relativamente à problemática assistencial, Carmem chama atenção para os aspectos singulares dos indivíduos, ignorados pelos profissionais de saúde.

"Eles tem que vê que nem todas as mães foram feitas pra ter parto normal. Apesar de que ter parto normal é bom, eu queria muito ter parto normal, que tem mais... Tem recuperação mais rápido, tem tudo isso, tem todas as vantagens, mas, como a pessoa não pode ter parto normal o que é que eu posso fazer? Não é fazer, forçar a ter parto normal... " [Carmem].

A fala de Carmem, a todo instante, é permeada por um contorno argumentativo e contestatório. Num vai e vem reflexivo de grande envergadura. 
Porém, em outras passagens da sua narrativa ela relaciona a causa da morte a um querer divino, diante do qual cabe aceitação.

"Num sei. Pra mim eu... Eu acho que Deus escreve certo por linhas tortas né. (....). Eu, pra mim eu disse assim, 'Foi Deus que quis assim, alguma coisa ele há né?' Pra mim eu botei isso na minha cabeça. Não culpo os médico... Sim, numa parte eu fico pensando - 'Se tivesse feito isso, tivesse feito aquilo...' Mas, tinha que acontecer isso né? Não posso fazer nada né? (...). Foi tudo direitinho, tudo normal, e de repente aconteceu isso, eu acho que foi Deus que quis né, não posso fazer nada. Eu tenho mais isso na minha cabeça. Eu não vou..." [Carmem].

Essa convicção, no entanto, logo em seguida, dá lugar a questionamentos, abrindo espaço a reflexão sobre a atitude não diligente do médico. Nesse sentido, diz ela:

"Claro que se... Se os médicos não tivessem forçado pra ser parto normal, se tivesse feito a cesárea logo, assim que eu tivesse chegado, eu acho que tinha uma possibilidade de eu ter minha filha do meu lado. Mas como foi tudo assim desse jeito, eu num... Eu acho que foi Deus que quis assim, pronto. Não vou brigar com os médico, nem vou procurar confusão, porque isso pra mim não vai trazer minha filha de volta. Isso... num vou botar culpa num e no outro porque não vai trazer minha filha de volta. Então, eu entrego nas mãos de Deus e pronto. Eu sou uma pe..." [Carmem].

$\mathrm{Na}$ busca por uma explicação, uma causa, para a morte do filho, Ivani retoma a queda sofrida quando estava com oito meses de gravidez, as dores que começou a sentir a partir de então e o uso de Buscopan, medicação prescrita pelo médico durante a consulta pré-natal.

“O médico só passava pra mim... Só passou pra mim um remédio pra dor... Buscopan. Até, quando eu tomava o remédio, eu dizia assim, 'Esse remédio 
menina falou que tinha duas qualidade. Ai eu fui pra outa, ai ele disse, 'Não...' O farmacêutico disse, 'Não, não tem duas qualidade.' Então me deu um, que só tinha um lá né. Ai eu tomei. Eu não sei se projudicou a criança sobre esse medicamento. Eu não sei o que foi". [Ivani]

Numa tentativa de compreender a perda sofrida lvani busca relacionar o acontecimento da morte ao comentário que ela ouviu de profissional de saúde sobre o posicionamento fetal intra-útero: “A médica falou que ele tava assentado. Então, eu fico pensando que deve ter sido por isso né, também, no mesmo tempo... sobre a posição de ter. Ai eu não sei" [Ivani].

No relato de Ivani, transparece alheamento sobre a ocorrência e, como principal incômodo, relativamente à perda do filho, a inclusão, na DO, de doença infecciosa como uma condição que contribuiu para a morte. Neste sentido ela se expressa:

"Agora eu fico maginando porque foi que aconteceu esse pobrema. Porque Graças a Deus... Todo mundo da minha famia tá revoltado tombém por isso. Porque, como foi que aconteceu esse probema nele, da doença dele. Você sabe qual foi a doença dele? (....). Pois pronto. É isso aí que é onde é que tá mais a complicação. Como é que se diz, a maginação minha... quanto minha... como a da minha famía. Por que é que foi essa... (...). Essa infecção. Ai eu... Todo mundo querendo saber como é que foi, por quê que foi isso aí. Essa parte ai. Eu não seio". [Ivani].

Qual o sentido do receio Ivani? Num tom defensivo manifestado, ela parece buscar proteger-se e a sua familia sobre a responsabilidade da morte.

Cristina tenta compreender a justificativa técnica da morte e estabelece julgamento acerca da explicação fornecida pela médica que realizou o seu parto. Para ela a demora na decisão por um parto cirúrgico ao invés de um parto vaginal foi que resultou na morte da criança. 
"Ela disse que foi porque passou da hora, ela disse que eu fiquei fazendo força demais e ele não nasceu. Eu não fiz força o bastante pra ele nascer. Então, como a bolsa já fazia algum tempo que tinha estourado, faltou oxigênio pra ele dentro da barriga. Então ele nasceu fraquinho. Ai eu cheguei a perguntar pra ela. 'Mas porque quando eu pedi pra senhora fazer a cesárea a senhora disse que não?' Ai ela não respondeu... Ela mudou de assunto. Ela disse, 'Não, mas foi por causa... que se ele, se ele... Mas você tem que compreender que se ele tivesse sobrevivido, ele ia ser uma criança problemática e você não ia gostar.' Mas, sempre fica essa pergunta pra mim. E ninguém nunca quer me responder. Será que se ela, na hora que eu disse pra ela que eu tava com falta de ar, que tava acontecendo alguma coisa, e eu pedi que pelo amor de Deus ela fizesse uma cesárea, será que se ela tivesse tomado a decisão naquela hora, pelo mesmos dez minutos antes, ele não teria nascido normal? Sem falta de oxigênio?" [Cristina].

Diversos aspectos da narrativa de Cristina assemelham-se às falas anteriores. $\mathrm{O}$ sentimento de insatisfação ao descrever o tipo de atenção recebida em seu primeiro parto e a crítica da atitude dos profissionais de saúde por ignorar que "cada caso é um caso". Ela chama atenção em seu depoimento para o fato de não ter sido reconhecida pela equipe de saúde quando da expressão da sua impossibilidade instalada durante o parto. Além disso, atribui a má assistência ao fato de ter sido atendida em hospital público. Numa certa medida, a narrativa de Cristina assume a forma de um lamento.

"Pra mim, eles tiveram um pouco de negligência, nesse caso. Eles deviam ter mais atenção. Tá certo, todo dia eles vêem a mesma coisa, mas, cada caso é um caso. Eles deviam tomar mais cuidado, ter mais atenção. Não sei se é porque... (....). Eu tenho pra mim que... eu não sei se é porque foi num hospital público, então eles não têm, assim, o devido cuidado né. Por exemplo, porque eu já tava com sete centimetros, a bolsa não tinha estourado eles estouraram, né. Mas, assim, na hora que eu tava dizendo que eu tava sem força, sem fôlego, eu tenho pra mim, que se fosse num hospital particular eles tinham tido assim, mais um zelo né. Teriam feito mais alguma coisa pra saber o que é que tava acontecendo. Porque eu estava com aquela falta de ar. Porque eu tava ficando... Porque eu tinha tido vontade de vomitar. Porque depois disso eu perguntei a algumas pessoas, algumas amigas minhas que já tiveram filho, elas disseram que nunca tiveram vontade de vomitar, nunca tinha tido falta de ar, na hora do parto. 
Então eu fíquei encucada. Porque então só comigo? Porque elas não viram que eu tava mal, que eu tava sem força, sem fôlego, não conseguia... Eu não tava conseguindo nem tomar fôlego, mais. O ar não vinha pra mim. Eu tava com a garganta tampada. Porque será que eles não fizeram um... Disseram, 'Não, vamos fazer logo alguma coisa. Vamos vê, que tá acontecendo alguma coisa errada.' Mas não, eles deixaram pra lá. Ela só fazia mandar eu fazer força, fazer força, mas eu dizia pra ela 'Não consigo.' Eu não conseguia nem falar direito. Eu não tava conseguindo falar. Eu não tava... Sei lá, eu acho que eles deviam ter tomado mais cuidado, deviam ter previsto..." [Cristina].

Esse depoimento sugere ainda a inexistência de avaliação clínica do caso. $O$ que pode ter determinado a decisão médica por uma conduta expectante nesse caso?

Percebe-se que tanto Carmem, quanto Cristina, cada uma a seu modo, em seus discursos, chamam atenção para um aspecto fundamental, e pouco considerado pelos profissionais de saúde por ocasião da assistência, refere-se ao respeito à singularidade do indivíduo.

Nessa mesma direção caminha o sentido das palavras de Neide. Para ela, a idéia do risco de morte passa pela falta do reconhecimento da singularidade do individuo. Em seu discurso isso transparece da seguinte maneira:

"Porque muitas crianças morrem aqui a risco disso. Bota logo na mente da gente que a gente tem capacidade de ter o filho normal. E quando vem fazer um parto... às vezes você não tem, e eles sabem. E quando vem tomar uma atitude já é... ou a vida da mãe ou a vida do filho". [Neide].

$\mathrm{Na}$ visão de Neide a perda do seu filho foi decorrente de negligência médica. Além disso, ela afirma não ter ficado convencida da explicação dada pelo médico acerca dos motivos que levaram à morte. 
"Desde o momento que eu entrei, que ela falou assim, eu não me convenci não. (....). Desde o momento que eu vim, pela primeira vez, se tivesse escutado ele... Ai eu boto isso (....) no meu eu. (....). Se tivessem, de primeiro lugar, tivessem escutado a criança, e ela ainda estivesse viva, que foi após o susto que eu vim pra cá. (....). Então era... (....). Eu, tendo passado por alguma coisa, ou não, era direito da médica escutar a minha criança. A primeira coisa que a médica tem que fazer é escutar a cri... é o filho da gente no ventre da gente. N... nós somos responsáveis por tá atento e saber se ele tá mexendo no dia a dia. Mas também num momento desse, elas tem a responsabilidade delas. Elas tem que atuar com a responsabilidade delas." [Neide].

Em tom bastante critico, Neide por diversas vezes refere-se ao mau desempenho da médica que a atendeu. Ao mesmo tempo em que divisa e compartilha responsabilidades com os profissionais de saúde no tocante ao cuidado.

Neide também diferencia a qualidade da atenção ao tipo de assistência pública ou privada-, atribuindo diferencial de qualidade se a assistência tivesse sido particular: "Porque eu acho que se fosse no particular não tinha se submetido a tantas coisas assim não, né?" [Neide].

Dalva aparentemente assimila a conotação religiosa dada pelos profissionais de saúde acerca da morte do filho, acontecida aos nove meses de gestação. Nesse sentido, demonstra resignação pela perda.

“... é uma coisa feita por Deus. Porque, eu faço como Dr. E. falou pra mim: 'Ninguém sabe explicar.' É uma coisa que a gente... (....). 'Ói Dalva, só Deus pode responder porque você perdeu seu filho.' Porque ainda passei, sete, oito, nove, vim perder ele com nove mês, dentro da barriga né? É uma coisa muito... Só Deus pode responder. (....). ... foi que nem a médica falou pra mim: 'Num é fome, num foi que sofreu, perdeu a criança...' (....). Foi uma coisa mandada por Deus. Deus foi que tirou, tá entendendo? Num foi uma coisa assim... com qualquer... (....). Aquilo ali foi uma coisa que Deus mandou... deu e ao mesmo tempo tirou, soube tirar". [Dalva]. 
Perguntada se ela tinha alguma idéia sobre o que causou a morte ela respondeu que "Não. Tenho não. $\dot{A} s$ vezes eu procuro a mim mesmo pergunto por que aconteceu tudo isso e pronto... Só o que eu tenho pra dizer. Foi só o que escutei da... dos médico. Pronto". [Dalva].

Em outros momentos Dalva demonstra uma certa confusão diante de justificativas, comentários, feitos por profissionais de saúde em sua presença durante a sua permanência na maternidade. Nesse sentido ela diz: "Falaram que morreu... Foi problema de coração. Então, minha pracenta que era estreitinha, então ele... o coraçãozinho dele chegou aquele momento que não dava pra resistir. Foi só isso". [Dalva].

Outra interpretação apresentada por Dalva a partir da fala dos médicos, acerca dos motivos que levaram a perda do filho é a seguinte: "É... Que nem o médico falou... Minha pracenta tava tão estreitinha... Que ele virou, ele virou e ficou... perdeu a respiração. Porque a pracenta ficou muito estreitinha. Foi assim que ele falou pra mim: 'Olhe Dalva seu filho...' Ai pronto. No que perdeu a respiração né...", [Dalva]

Num outro momento ela esboça algum questionamento ao se referir a outros comentários relacionados à morte do feto e ao tipo de parto, porém não o faz com clareza:

"É. É isso que eu tava encucada. Até em casa eu dizendo um dia: - 'Como é que pode? Se morreu há dois dia... 'Já tava morto na barriga né, quando eu cheguei aqui que eles olharam, já tava morto. E por que se fosse cesárea ele tava... ele escapava? Não sei. Ou ele escapava ou morria. Me escapava e eu morria. Então escolh... É por isso que eu tô dizendo... O médico foi e disse: 'É por isso que Deus sabe o que faz.' Deus olhou, viu que era melhor tirar meu filho do que eu. Porque se fosse cesáreo... tá entendendo? Eu morria e o menino ficava. É uma história que a gente fica..." [Dalva]. 
Dalva parece utilizar o discurso religioso como estratégia de convencimento e conformação. Em algumas passagens da sua narrativa, mesmo afirmando ter ficado satisfeita com as explicações dadas pelos profissionais de saúde durante a sua permanência na maternidade, pode-se perceber a inexistência de assimilação e incorporação das explicações oferecidas.

Num trecho da narrativa de Liana ela diz acreditar que a morte do seu filho foi causada por "desgosto", nesse sentido a sua fala denota culpa:

"Ele sofreu muito. Eu acho que essa dor que eu sinto foi... É mais porque eu sei que ele sofreu, porque, pelas coisas que eu já passei. Principalmente na gravidez dele, eu passei muita coisa. E ele sofreu, muito. Mas a gente... Eu me arrependo muito de ter feito ele passar por muita coisa, mas a gente não manda no coração nem no sentimento, né? Passei muito aperreio. (....). Pra mim, eu acho que ele morreu de desgosto. Eu acho. Tudo o que eu passava ele passava. A maioria toda... quase toda da minha gravidez foi chorando com desgosto da vida. Eu acho que ele ficou desgostoso" [Liana].

É possível supor que a auto-culpabilização manifestada por Liana ao expressar sua responsabilidade pela morte do filho possa decorrer dos muitos momentos em que o rejeitou durante a gravidez. Em seu relato a conotação de responsabilidade como culpa ganha sentido em dois momentos: em primeiro lugar quando atribui a perda ao sentimento de rejeição e desejo de morte dirigido ao filho quando estava grávida, e no seu hábito de fumar. Como se sabe, a mencionada gravidez de Liana, por sua decisão, não teve acompanhamento pré-natal, postura diferente da adotada por ela nas cinco gestações tidas anteriormente. Essa era uma gravidez explicitamente referida como não desejada.

Maria também chama para si a responsabilidade sobre a perda do filho, por não ter percebido as alterações no ritmo e na intensidade dos movimentos fetais, e por 
não ter sido suficientemente diligente no cuidado consigo. Uma outra modalidade de culpabilização a partir disso é significada.

"Eu como..., com minha atividade profissional, não soube utilizar esses meus conhecimentos pra poder identificar isso comigo. A vida corrida, de hospital que a gente vive, de cima pra baixo, de baixo pra cima, sempre atendendo o outro, e a gente, sempre ficando pra depois. Eu acho que isso contribuiu, pra que eu não conseguisse identificar que meu bebê tinha parado de mexer. O cansaço, quando chegava em casa, era tanto que adormecia logo em seguida. Então isso é..., eu acho que deve, que deve ter contribuído pra que eu não notasse que o bebê, bebê tinha parado de mexer" [Maria].

É possivel observar que a interpretação dada por Maria para a morte do filho se mostrou, em certa medida, diferenciada da das demais mulheres. A tensão envolvida na perda de Maria não parece incluir: sentimento de insatisfação relativamente ao plano assistencial, a relação médico-paciente no processo da gestação e parto, nem ao cenário cujo parto foi realizado.

BOLTANSKI (1984) referindo-se as regras que determinam os comportamentos físicos dos agentes sociais, cujo sistema constitui sua "cultura somática", afirma que estas são produto das condições objetivas que elas traduzem na ordem cultural, ou seja, conforme o modo de dever-ser; elas são função, precisamente, do grau em que os individuos tiram seus meios materiais de existência de sua atividade fisica, da venda de mercadorias que são o produto dessa atividade, ou do emprego da sua força física e de sua venda no mercado de trabalho.

Para o autor, se os indivíduos prestam tanto menos atenção ao corpo e mantêm com ele uma relação tanto menos consciente quanto mais intensamente são levados a agir fisicamente, “... é talvez porque o estabelecimento de uma relação reflexiva com o corpo é pouco compatível com a utilização intensa do corpo. Primeiramente, o 
esforço fisico torna dịficil a seleção e a indicação das sensações doentias ou, se quisermos, introduzir ruido na comunicação entre o sujeito e o seu corpo; em segundo lugar, o aumento da atenção dada ao corpo e, correlativamente, da sensibilidade às mensagens mórbidas, tem como resultado necessário à redução de duração e intensidade da atividade fisica..." (p.168).

No caso de Maria é patente "o ruído na comunicação entre o sujeito e o seu corpo", e o embotando da sua sensibilidade às mensagens advindas do corpo grávido - possivelmente estabelecido pelo excesso de trabalho enquanto enfermeira.

Não obstante, ela expressa ter percebido alguns sinais precursores de que algo não estava bem com a sua gestação. A experiência de parturição anterior, o seu nível de instrução, deu-lhe elementos para que pudesse identificar o silenciar gradativo dos movimentos fetais. Apesar do seu corpo ter dado sinais, parece que estes foram recusados, "como uma forma de se continuar utilizando um corpo sadio" (ANDRADE e col. 1997 p.25). Nessa suposta recusa ao evidenciado, o corpo "fala" mas não é escutado, testemunhando, assim, de uma espécie de surdez em relação aos sinais que se mostram (SOUZA 1999).

Segundo SOUZA (1999), "Para que possamos nos ocupar do nosso próprio corpo, é preciso que sejamos capazes de nos imaginar como podendo ficar doentes. O que está em jogo aqui é a dimensão de finitude do sujeito, (....), com a possibilidade de aceitar a realidade das limitações do corpo".

Retomando o capítulo três é possível verificar que responsabilidade - seja por ação ou por omissão-, é um termo subjacente à noção de risco, enquanto portador de um sentido de causalidade e relacionado à atitude individual, comportamental, situacional. 
"Assim, questão de eu não ter ido procurar. [Com fala chorosa] Porque... pelo fato que tava se mexendo muito, dizer assim, 'Eu acho que eu vou no médico.' Ai fica aquele negócio, 'Vai hoje, vai amanhã', e o tempo, e trabalho e. sempre deixando pra manhã, aquela... " [Maria]

$\mathrm{Na}$ fala a seguir Maria reitera mais uma vez o sentido de responsabilidade com relação à perda do filho.

“Ai eu fic.... e u parava e ficava pensando, assim: 'Não, eu não vou culpar ninguém, pelo que aconteceu comigo. 'E até mesmo assim: 'Eu também não vou me culpar, que foi um...' Não vou ficar me culpando porque ai eu vou ficar com essa culpa pra cima de mim pro resto da vida, dizer que realmente, como eu era da área de saúde tinha que ter me cuidado mais, tinha que ter visto isso mais de perto, tinha que ter é... observado mais as coisas. Mas a gente sabe quê, quem é da área de saúde, sempre deixa a gente pra depois [Maria sorriu]. Nunca a gente é primeira, nós somos a segunda pessoa, sempre é cuidar do outro, o outro é mais importante, o outro tem que faz... A gente: 'Não, vou hoje, vou amanhã', vai só empurrando pra depois" [Maria]

O nítido dilema vivenciado por Maria, pelo fato de pertencer à área de saúde intensifica a noção de responsabilidade a qual vimos nos referindo. Desta feita a conotação da culpabilização por ela vivenciada assume um duplo sentido: o da mãe que não cuidou e da profissional negligente.

\subsection{Enfocando a evitabilidade da morte perinatal}

Para Íris, a falta de um diagnóstico precoce provocou o retardo da decisão médica pelo parto cirúrgico. Nesse sentido, ela se pronuncia: 
“... se eu tivesse batido uma ultra, quando eu comecei sentir a dor, eu já fazia um cesáreo, nera? Ai evitava do menino nascer fora da hora. Evitava ficar levando dedada. Aquilo ali, negócio de ficar examinando, examinando, examinando, passou muito do tempo. Porque passou um bocado de hora, porque cada estagiário me examinava. Ai nisso eles dizia que tava com num sei quantos centimetros. Uns dizia que tava com oito. Outro dizia que tava com sete. Outro dizia que tava sete por oito... e que... Outro dizia que tava oito por oito e que não tava perto de ter ainda. Foi um rolo todo. (....). ... se tivesse batido a ultra eu tinha tido ele e talvez ele tivesse vivo. Por que ai eu não ia passar por esse monte de sufoco né, que eu vim pra cá, fui pra lá, de lá vim pra cá de novo. Cheguei aqui demorei mais meia hora na sala de cirurgia porque eu nervosa gritando não conseguia relaxar pra anestesia pegar". [Íris].

Íris em sua narrativa refere-se a violência institucional a que foi submetida, peregrinação interna até que se tomasse uma decisão relativamente ao parto.

$\mathrm{Na}$ opinião de Carmem uma maior atenção médica sobre o seu caso particular poderia ter evitado a morte do seu filho. "Eu acho que se eu... se o primeiro médico que tivesse me atendido tivesse mais prestado mais atenção em mim, não ter mandado eu ir pra casa, ter ficado mais em observação comigo, eu acho que teria evitado alguma coisa" [Carmem].

Assim como Íris, ela também identifica falhas no atendimento ao parto. Nesse sentido, ela atenta para a ausência de uma avaliação, por parte da equipe de saúde, sobre as condições do feto antes de nascer.

“... outra possibilidade, se eu tivesse chegado aqui na Maternidade... e a médica tivesse me examinado... Uma Maternidade que tem tanto aparelho, podia ter chegado, de ter escutado o coração, ter feito uma ultra-sonografia e ter visto, né? (....). Tá vendo que a nenê tá defecando, tá com alguma coisa, chegasse lá, fizesse a ultra-sonografia, visse como é que tá o nenê dentro. (...). ... porque na ultra-sonografia dava pra vê se tava com o cordão umbilical enrolado no pescoço (....). É isso que eu penso, que se tivesse agido logo no começo, não tivesse tanto... Um vai e faz a prova de toque, outro vai e faz a prova de toque, ai vão, se reúne e conversam. Acho 
que se tivesse agido logo dessa maneira eu acho que a minha filha taria viva né?" [Carmem].

O que teria evitado aos olhos da mãe teria sido melhor atenção. A sua crítica se apóia nas informações obtidas através da imprensa acerca da possibilidade de detecção precoce da circular de cordão através do exame de ultra-sonografia. Vejamos:

"Eu acho que na ultra-sonografía acho que dava pra vê se ela tava como cordão enrolado no pescoço ou não. Como eu vi com... na cantora Simoni. Ela pensava que ia ter parto normal, mas ela foi fez... o médico examinou ela e viu que o nenê tava com o cordão enrolado no pescoço e fez uma cesárea". [Carmem].

$\mathrm{Na}$ sequiência da sua tentativa por explicar os aspectos implicados na evitabilidade da morte do filho Carmem estabelece relação com a sua situação econômica e o tipo de assistência, pública x privada:

"Eu acho que depende muito de condições. Eu acho que hoje em dia a pessoa só... Se depender disso eu acho que só tendo condições mesmo porque... Um Plano de Saúde. alguma coisa... Acho isso. Que se eu tivesse um Plano de Saúde, tivesse um médico, eu acho que dava pra ter evitado tudo isso né? Mas, como não tenho condições, tem que ter assim mesmo né, nos Posto, nas Maternidade, depender do Governo, né. Pra mim eu acho... Eu acho... [Carmem]

A percepção da sua condição social e a relação entre esta e o tipo de assistência recebida faz supor que Carmem tem noção da sua condição de vulnerabilidade ${ }^{26}$ social e institucional conforme apontado por AYRES $(1996,1999)$.

\footnotetext{
${ }^{26}$ A noção de vulnerabilidade busca estabelecer uma síntese conceitual e prática das dimensões sociais, político-institucionais e comportamentais associadas às diferentes suscetibilidades de indivíduos, grupos populacionais e até mesmo nações... (....). A noção de vulnerabilidade visa fornecer elementos para avaliar objetivamente as diferentes chances que todo e qualquer individuo tem de se
} 
No que lhe toca pessoalmente ela atribui, a si, o erro por não ter falado: "Eu acho que o erro foi... eu acho que se eu tivesse abrido a minha boca pra falar mais eu acho que tinha sido diferente. Eles iam pensar duas vezes, que eu tava falando ia agir do jeito que eu tava pensando, né". [Carmem].

Direcionando o foco do nosso olhar sobre o apagamento da singularidade individual, decorrente da rígida sujeição às normas preconizadas, podemos pensar, a partir dos discursos obtidos, que a atenção médica não leva em conta tais aspectos. Não parece haver lugar, dentro do cenário institucional de saúde e no campo da assistência a saúde sentimentos como, emoção, medo, crenças, valores, dentre outros. inerente à pessoa.

A fala de Cristina a seguir nos conduz a essa afirmação.

"Eu tenho pra mim isso. Se ela tivesse tomado, na hora que eu comecei a dizer que 'Eu tô com falta de ar, por favor me ajude! Eu não tô conseguindo respirar!' Se naquela hora ela dissesse "Vamos fazer uma cesárea nessa menina agora.' E tivesse me levado pra cirurgia talvez ele tivesse nascido, talvez tivesse descobrido (sic) logo, que ele tava com aquele negócio no pescoço e não tivesse tido insuficiência respiratória. Mas, como eu ainda fiquei pedindo muito tempo... Eu acho que eu passei quase meia hora pedindo a ela pra que ela fizesse a cesárea". [Cristina].

Em publicação recente sobre a "Humanização na saúde", MARTINS (2002) faz algumas considerações acerca da não valorização, por parte do profissional médico extensivo a outros profissionais da área de saúde - de aspectos da singularidade do

contaminar [adoecer, morrer], dado o conjunto formado por certas características individuais, sociais de seu cotidiano. Julgadas relevantes para a maior exposição ou menor chance de proteção diante do problema. (AYRES JRC. Vulnerabilidade e avaliação de ações preventivas. São Paulo, Editoração eletrônica, Casa da Edição, 1996). (Grifo nosso) 
paciente. Para a autora, o ato médico, ao longo do tempo, se desumanizou como conseqüência do acelerado processo de desenvolvimento tecnológico em medicina. Nessa mesma direção, a doença assumiu o lugar do doente, enquanto objeto de saber reconhecido cientificamente. Além disso, afirma a autora, ocorreram transformações na formação médica, cada vez mais especializada, e nas condições de trabalho, restringindo a disponibilidade do médico tanto para o contato com o paciente quanto para a busca de formação mais abrangente.

Cristina. assim como as outras que a antecederam, em seu depoimento expõe muito claramente o que. no contexto assistencial, poderia ter evitado a morte do seu filho:

"Mas, eu acho que, pra mim... Eu tenho pra mim, que se a médica tivesse feito a cesárea logo, não tivesse tentado fazer que eu tivesse... tanto ele pra fora, talvez ele tivesse nascido bem. Eu tenho isso pra mim. Mas, eles dizem que foi o que, foi que ele nasceu enrolado, e porque eu não tive força de colocar ele pra fora. Ai eu fico... Eu fiquei chateada. Fiquei triste porque também eu pedi, eu pedia, eu chorava pra que ela fizesse logo uma cesárea. que eu sabia que tava acontecendo alguma coisa. Eu não tava com forças pra colocar ele pra fora. Mas ela dizia que: 'Não. Você tem que botar ele pra fora. Você tem que fazer esse parto normal'.' Ai foi preciso o plantonista vim. conversar com ela, pra ela poder fazer a cesárea comigo ". [Cristina].

Franca expressa, em alguns trechos da sua fala, que o procedimento médico adotado teria sido a condição necessária para que a morte do filho tivesse sido evitada.

"Sei não. Eu acho.... se eu tivesse, é... tido uma cirurgia, eu acho que eu não tinha perdido o meu bebê não. [Chorando] (....). Porque eu não senti... não senti dor nenhuma. Do outro meu menino que eu tive, a bolsa estourou em casa, eu senti muita dor. E desse eu não tava sentindo dor nenhuma. E sempre eu perguntava a médica se não era o caso de fazer uma cirurgia. 
ela disse que não. Não tinha indicação nenhuma de cirurgia, porque o outro eu tinha tido normal. Mas, nem todo parto é igual né?" [Franca]

Franca estabelece diferenciação entre a qualidade do serviço público versus serviço particular na assistência ao parto, desqualificando o serviço público.

"Eu acho que se eu tivesse feito uma cesárea ou então, se eu tivesse um Plano de Saúde, tivesse um acompanhamento melhor, eu acho que não tinha morrido também não". [Franca]

Tendo conferido a si mesma a responsabilidade pela morte do filho Liana puxou para si a possibilidade de ter evitado a morte do filho:

"Talvez se eu tivesse deixado os poblemas de lado, as coisas correrem mais. Acho que ele tinha resistido. Acho que foi... Acho que ele sentiu desprezo. Acho que ele sentiu... Dizem que a criança escuta a mãe... Ele sentiu... Eu acho que... Eu chorava, eu acho que, ele chorava também".[Liana]

Na mesma direção foram feitas também as colocações de Maria:

"Assim, que eu acho que, se tivesse até visto antes de eu tá nessa grande atividade que ele tivesse tendo, se eu tivesse procurado o médico que estava me acompanhando eu acho que isso poderia ter sido evitado. né. Então, de certa forma foi uma falha minha também de não ter procurado o profissional né, é, pra relatar a ele esse fato que tava mexendo muito, se não era bom fazer uma ultra pra uma avaliação, né? Mas... " [Maria]

\subsection{Reflexões preliminares sobre a experiência da perda}

Em nossa sociedade, o que pode ser mais ameaçador do que a morte?

Sem querer direcionar a nossa análise para o conhecimento da representação social da morte - como conseqüência da vontade divina - é importante considerar 
nesse aspecto, a menção a MOSCOVICI (1978), feita por OSAVA e MAMEDE (1995), ao destacar que:

“... a representação social de um objeto tem a finalidade de diminuir a ameaça que ele - objeto - representa, e ao mesmo tempo, restituir a identidade que ele questiona. (...). 'Uma representação social surge onde houver perigo para a identidade coletiva, quando a comunicação de conhecimentos submerge as regras que a sociedade se outorgou', (OSAVA e MAMEDE 1995:6-7).

Para todas as mulheres entrevistadas a experiência da morte perinatal teve uma conotação de imprevisibilidade, de algo inesperado. No grupo estudado. esse aspecto inopinado, gerador de perplexidade e incerteza, teve em algumas vozes o correspondente sentimento de medo, de insegurança e de ameaça. Neste sentido o apelo ao plano divino, na busca de conforto e resignação transparece como uma forma de representação social relativamente à morte do filho.

Contudo, a percepção materna sobre as circunstâncias do acontecimento da morte. obtida a partir da experiência da perda nos impulsiona o desejo de discorrer um pouco mais sobre o tema desenvolvido por OSAVA e MAMEDE (1995), a partir de MOSCOVICI (1978) ao atribuir três dimensões à representação social: 1) $a$ informação, ou seja, o conjunto de conhecimentos que um grupo possui a respeito de um objeto social; 2) a atitude. exprimindo a orientação geral, positiva ou negativa. face ao objeto da representação social; 3) o campo de representação, que se vincula à idéia de 'imagem".

A passagem anterior, enquanto elemento de reflexão, nos levou a um primeiro reconhecimento sobre a necessidade de divisar dois momentos cruciais do processo 
de conhecimento das mulheres que participaram dessa pesquisa: 1) o conhecimento precedente à experiência e que demarcou a atitude dessas mulheres a demanda. ou não, por assistência; 2) o conhecimento construído a posteriori, ou seja, proveniente da experiência da perda. Este último coloca em cheque o conhecimento anterior e tudo o que ele representa - informação, confiança, segurança, crença - dando lugar a um outro conhecimento (re) significado, pautado na perda da confiança, na insegurança, ameaça e medo instalados. Assim, o sentido novo do conhecimento, expressado através do discurso, marcado pela cisão anteriormente colocada transparece sob a forma de mecanismos de ajustamento pessoal e de superação da frustração, de defesa e de proteção. 


\section{8. (Re) significação do risco perinatal}

\subsection{Novas feições no tratamento do risco}

Depois de ter percorrido todo esse trajeto na busca por localizar em algum ponto da fala das mulheres sobre as suas experiências relativamente à perda do filho, um lugar reservado ao risco, enquanto uma noção que pudesse dar maior visibilidade ao desfecho da morte perinatal, pudemos observar. nas conotações atribuídas ao termo, um forte componente subjetivo relacionado à percepção, sensação ou sentimento diante da ameaça ou presença (real ou potencial) perigo, circunscrito a aos momentos do pré-parto e do parto.

Sob esse ponto de vista a noção de risco assume diferentes feições, tais como: perigo - diante da situação de insegurança gerada no momento do parto; ameaça, medo, desamparo - ante suposto perigo, a partir do prenúncio de que algo indesejável poderia acontecer; responsabilidade - correlacionada ao cuidado (ou não cuidado) de si e como julgamento acerca da atitude individual, comportamental. situacional, e no sentido de causalidade - relacionada à análise dos efeitos obtidos da experiência e da sua evitabilidade.

Não obstante, torna-se impossível conduzir essas reflexões acerca da produção de sentido atribuído ao termo, deslocado do aspecto interacional, social e culturalmente construido, que lhe dá suporte. Tal modo de encarar permite dar maior visibilidade à relação desigual entre as pessoas, tanto do ponto de vista da inserção social - cuja distinção é, em parte, traduzida pelas mulheres através da percepção 
sobre a sua condição de vida, através da qual estabelece diferenciação entre a qualidade do serviço público versus serviço particular na assistência ao parto, e no maior ou menor acesso à tecnologia-, como da apropriação/desapropriação do conhecimento - por distinção, o conhecimento técnico científico versus o conhecimento trazido pela experiência - trazida pelas mulheres através da impossibilidade de se colocar, de sugerir, de falar de si mesma. Nesse sentido, o espaço institucional revela-se como lócus de reprodução e de manifestação da mencionada desigualdade.

A exposição desse cenário foi tornada possível ao se adotar como ponto de partida do nosso olhar, a perda como uma realidade na vida das mulheres entrevistadas. A partir desse momento, o risco, antes conteúdo, torna-se uma forma passivel de desvelar uma outra dimensão relacionada ao espaço no qual as relações sociais se realizam.

Nessa tradução, o risco é convertido, transmudado em múltiplas possibilidades, através das quais torna-se possível a sua visualização no conjunto de circunstâncias que integram a experiência e através do julgamento das mulheres sobre o acontecimento da perda.

Assim, no presente trabalho a noção de risco é trazida pelas mulheres nas seguintes formas:

1) Na crítica ao serviço de saúde por ocasião do pré-parto e parto:

- Peregrinação externa (entre instituições) e interna (no interior da própria instituição) da mulher durante o trabalho de parto. 
- Pouca importância dada ao quadro clínico, configurando negligência médica $^{27}$, erro médico, ausência de monitoramento da criança por ocasião do atendimento no pré-parto e parto, não percepção da gravidade do caso pela equipe de saúde, demora em decidir sobre o parto cirúrgico (conduta expectante).

- Desrespeito à singularidade da mulher. Não consideração da queixa da mulher sobre os seus sintomas e indícios da gravidade do caso.

- Não utilização da informação do pré-natal como auxiliar na clínica obstétrica.

- Desqualificação da assistência oferecida pelo hospital público.

2) Na menção a atitude considerada arriscada. como o hábito de fumar - os casos de Íris e Liana.

3) Na referência a idade reprodutiva, como no caso de Franca.

4) No relato de algumas intercorrências clínicas e obstétricas durante a gravidez.

Entre as nove mulheres entrevistadas, sete mencionaram haver peregrinado por diversos serviços de saúde antes de ser admitida para a realização do parto. Provavelmente em virtude da falta de vagas ou por deficiência na estrutura - de algumas maternidades.

Esta peregrinação foi referida em quatro casos de óbitos fetais - Neide, Dalva, Franca e Liana, cujos pesos dos seus bebês ao nascer corresponderam a $3.700 \mathrm{~g}$., 2.335g., 2.650g.. e $2.700 \mathrm{~g}$., respectivamente. Em três óbitos neonatais precoces também foi referida a peregrinação da gestante na busca de assistência hospitalar

\footnotetext{
${ }^{27}$ O termo negligência, conforme designado por FERREIRA (1999), significa: 1. Desleixo, descuido, incúria. 2. Desatenção, menoscabo, menosprezo. 3. Preguiça, indolência. (FERREIRA ABH. Novo Aurélio Século XXI: O dicionário da língua portuguesa. 3ed. Rio de Janeiro: Nova Fronteira, 1999).
} 
para o parto - Íris. Carmem, Ivani, cujos pesos dos seus bebês ao nascer corresponderam a $3.480 \mathrm{~g} ., 3.545 \mathrm{~g} ., 2.550 \mathrm{~g}$. respectivamente.

Essa dinâmica do processo de internação na busca por assistência hospitalar no pré-parto tornam. segundo TANAKA (1995). esse momento da procura do serviço de grande vulnerabilidade e risco, com repercussão no prognóstico final do ciclo gravídico-puerperal. Nesse sentido, para esse grupo de mulheres do nosso estudo. tendemos a acreditar ter sido este um atributo de importância decisiva para o desfecho da morte perinatal.

No entanto, vale dizer que o problema da peregrinação não foi uma manifestação isolada na história dessas mulheres. Com a peregrinação outras manifestações de violência institucional foram mencionadas. Cristina por exemplo, não precisou percorrer diversos hospitais para ser assistida, porém, a descrição feita por ela sobre o seu atendimento denota a condição de elevada violência a qual foi submetida durante o seu parto.

As narrativas indicam ainda a dificuldade de ouvir a gestante. A construção das hipóteses diagnóstica a partir da escuta mostrou ser uma prática pouco comum no atendimento a gestante. Alia-se a esse fato a impessoalidade no atendimento acarretando na mulher sentimento de desvalorização e de utilização.

Em suma. o risco decorrente da situação e a vulnerabilidade da gestante são agravados pela frágil relação instituída entre a equipe de saúde e a paciente.

Pelo que se pôde perceber dos relatos e da interpretação realizada, um atendimento em que a mulher fosse considerada em sua integralidade $\mathrm{e}$ singularidade, um atendimento direcionado na perspectiva do reconhecimento dos direitos reprodutivos, no qual a mulher estivesse inserida no pleno exercicio de 
cidadania. tivesse garantido a sua segurança e dignidade no atendimento à gestação e ao parto - maior agilidade e eficiência no atendimento, diagnóstico precoce sobre o risco da gestante e do feto. indicação precisa da cirurgia sem a espera desmesurada pelo parto vaginal-, certamente poderia ter levado a um outro desfecho que não o da morte perinatal em alguns casos.

A propósito, convém mencionar a possibilidade de equivoco em contabilizar cesárea como fator de risco de morte perinatal. Esse dado se não for bem examinado pode criar uma distorção.

Portanto, causa e evitabilidade da morte perinatal são duas categorias identificadas a partir do discurso materno, que se apresentam localizadas no foco da assistência recebida. no âmbito das relações assistenciais (relação instituição-usuário; profissionais de saúde-paciente), durante a gravidez e no momento do parto.

\subsection{A evitabilidade da perda refletindo como espelho o risco da morte perinatal.}

De uma maneira geral, não são muitos os estudos existentes contemplando a temática da evitabilidade da morte perinatal. Além do mais, não é do nosso conhecimento a existência de qualquer outro trabalho abordando esse tema a partir da ótica materna e na perspectiva de uma análise qualitativa.

Sendo assim, recorremos a alguns trabalhos a respeito do assunto na busca de uma aproximação para o reconhecimento dos nossos achados.

O trabalho desenvolvido por ROSA e HORTALE (2000), por exemplo, nos ajuda nessa aproximação. Nesse trabalho, particularmente, as autoras buscaram estudar a ocorrência de óbitos perinatais, tidos como potencialmente evitáveis. 
relacionando-os às falhas do atendimento obstétrico - por deficiência na estrutura de algumas maternidades, que compunham a rede do SUS, do município do Rio de Janeiro. Nesse estudo, foram considerados óbitos perinatais potencialmente evitáveis aqueles que poderiam ter sido evitados por cuidados adequados e que não foram dispensados.

Num trabalho anterior ao mencionado acima, ROSA (1998) op. cit. ROSA e HORTALE (2000), já havia estudado a relação entre morte perinatal potencialmente evitável com a qualidade dos cuidados dispensados às mulheres economicamente desfavorecidas. Os resultados desse estudo apontaram deficiências no processo de atendimento as mulheres incluindo: falhas no exame por ocasião da admissão da mãe na maternidade, dificultando a detecção de uma condição de risco; falhas no acompanhamento da evolução do trabalho de parto; falhas do acompanhamento e monitoramento fetal; um intervalo grande entre a decisão de fazer uma cesariana e sua efetiva realização; a não realização de transfusão sanguínea em caso de placenta prévia com hemorragia; a não aspiração de mecônio antes da primeira inspiração do bebê e a utilização inadequada de fórceps.

Os achados desse trabalho conferem ressonância ao que pudemos verificar em grande parte das falas maternas sobre o que motivou a morte e o quê poderia ter evitado.

Evitar, diz FERREIRA (1999), significa: 1. Fugir a; desviar-se de (coisa nociva ou desagradável); 2. Esquivar-se ao encontro, ao trato ou convivência de: 3 . Impedir, atalhar.

Num exercício do pensamento torna-se interessante refletir sobre o significado do termo evitar, e sobre os seus desdobramentos e implicações, retomando mais uma 
ao conceito de representação social, apresentado como uma forma de conhecimento especifico, uma modalidade de pensamento prático, orientado em direção à comunicação, a compreensão e ao domínio do ambiente e das idéias (JODELET 1984. Op. cit. OSAVA e MAMEDE 1995). Estas últimas são formas de conhecimento que se engendram na interface de dois processos: um processo grupal - expresso pelo imaginário social de uma sociedade, e um processo individual - onde situam-se as demandas funcionais do mundo vivido. Portanto, inclui os conteúdos que circulam numa dada sociedade, e que tem suas origens tanto nas produções culturais mais remotas, quanto nas produções locais e atuais que emergem da convivência cotidiana (SPINK 1993. Op. cit. OSAVA e MAMEDE 1995).

Partindo desse enfoque permitimo-nos dar vida ao termo evitar, adicionandolhe alguns termos geradores de sentido que possam nos auxiliar no exercício reflexivo necessário para pensar a evitabilidade da morte a partir das experiências narradas sobre a perda do filho. Neste sentido, evitar implica conhecer, ter uma visão antecipada, seja através de uma percepção anterior a partir da experiência própria ou de outrem. seja por meio de estudos sobre os acontecimentos diversos relativos ao viver e ao morrer. Evitar conota escolha e pressupõe, por conseguinte, ação, atitude, comportamento. Em suma, evitar implica conhecer, antever e proteger.

Por que razão situações e intercorrências durante a gravidez não puderam ser percebidas pelos profissionais de saúde como arriscadas, durante o pré-natal ou durante o trabalho de parto? Por quê manifestações, sinais, teoricamente passiveis de serem diagnosticados - placenta prévia, descolamento prematuro de placenta, hipertensão na gravidez, eliminação de mecônio, demora na evolução do parto, etc. não foram percebidos como merecedores de cuidado especial, agilidade no 
atendimento, no decorrer da assistência à gestante em trabalho de parto e por ocasião do parto?

Mesmo admitindo a possibilidade da existência de falhas no processo de atendimento às mulheres - por exemplo, a não identificação de condições de risco e demora em intervir em situações de sofrimento fetal - como decorrentes de falhas na estrutura de atendimento - estrutura física, serviços e equipamentos; organização de pessoal, deficiências na qualificação profissional e do ambiente profissional da prática (ROSA e HORTALE 2002), em que medida estes aspectos técnicos e estruturais ajudam a compreender as falhas na comunicação entre os profissionais de saúde - paciente, relativamente à ocorrência de óbitos perinatais potencialmente evitáveis?

Ao que se pôde perceber a partir dos depoimentos dessa investigação, o plano assistencial parece ter perdido um dos mais simples e fundamentais elementos necessários ao estabelecimento da relação entre as pessoas, a escuta ${ }^{28}$. Este sentido, necessário à comunicação, no plano da assistência a saúde, aparentemente apresentase desfocado e ruidoso, dando a impressão de que o espaço destinado ao encontro entre pessoas certas, na hora e lugar certos. não passa do seu oposto, um grande desencontro.

Segundo SCHILLER ( $\mathrm{s} / \mathrm{d})$ há verdadeiramente pouco espaço para a escuta do que o paciente tem a dizer. Muitas vezes incentiva-se o silêncio. Além do que, em

\footnotetext{
${ }^{28} \mathrm{O}$ verbo escutar, originado do latim auscultare, remete ao método da escuta médica, a auscultação, que significa literalmente a "escuta dos barulhos internos do sujeito" - método que significa aplicar o ouvido com atenção para perceber ou ouvir, ouvir com atenção. Precisamente dar ouvidos a ... dar ouvidos àquilo que se enuncia apenas veladamente, àquilo que somente um ouvio atento $e$ experimentado na arte de escuta pode acolher (SOUZA MLR. Os diferentes discursos na instituição hospitalar. Percurso 23(2), 1999) [on line]..
} 
nome de certa objetividade, o médico segrega sentimentos e emoções num compartimento que não participa do cotidiano profissional.

Porém, para o autor o currículo do curso médico habitualmente não oferece nenhum instrumento para a discussão aprofundada dos dilemas da vida e da morte, dos laços de parentesco e dos dramas familiares, das dificuldades educacionais, conjugais ou sexuais. A clínica médica contemporânea é, por excelência, uma clínica do olhar e dos números. E, a medicina moderna constitui-se como uma clínica que privilegia o olhar e a matemática, ou seja, tudo aquilo que pode ser observado e mensurado. A microscopia, as provas laboratoriais, a radiologia e suas ramificações contemporâneas sofisticadas, são herdeiras dos passos decisivos dos clínicos pioneiros do século XVII. É sobre esses pilares, o olhar e os números, que as conquistas extraordinárias dos últimos anos se fundamentam. $\mathrm{O}$ entusiasmo pelos avanços possibilitados pela primazia do empírico e da tecnologia ofuscou a percepção de que nesse percurso algo se perdia.

Nessa mesma linha de reflexão, SCHILLER (s/d) considera que talvez uma das perdas maiores tenha sido a confusão entre mecanismo e causa. Como exemplo, um aumento de secreção de adrenalina não é a causa de uma taquicardia; é o seu mecanismo. A obstrução de um ramo das artérias coronárias traduz apenas o mecanismo de um enfarte do miocárdio. As causas da taquicardia ou do enfarte, possivelmente residirão numa crise conjugal ou financeira, em contrariedade depressão ou ansiedade processada pelo psiquismo e que atuarão sobre o terreno fisiológico propício. (...). A descoberta da intimidade dos processos orgânicos garante a compreensão dos mecanismos, mas não necessariamente das causas. 
A primazia do olhar atirou a um segundo plano a dimensão da escuta. Porém, a medicina é prática humana e suas deficiências retratam a franqueza do gênero humano.

Não obstante, o resgate desse elo perdido na relação entre profissionais de saúde--paciente, a valorização da subjetividade humana, vem aos poucos sendo introduzidos no debate em fóruns de discussão.

MARTINS (2002), em seu artigo sobre a "Humanização na saúde: relação médico-paciente no microscópio", chama atenção para o fato de que a melhoria na estrutura fisica de instituições hospitalares, por exemplo, constituem-se em medidas relevantes, no entanto, "podem ser fatores meramente pontuais se não estiverem inseridos em um processo amplo de humanização das relações institucionais" (p.28). Para uma avaliação da complexidade da tarefa assistencial, em especial a realizada em instituições, diz a autora, deve-se considerar: a) que o paciente encontra-se inserido em um contexto pessoal, familiar e social complexo; b) que a assistência deve efetuar uma leitura das necessidades pessoais e sociais do paciente; que na instituição interatuam as necessidades de quem assiste e de quem é assistido. Neste sentido, as reflexões sobre a tarefa assistencial remetem ao campo ético.

Assim. ao profissional de saúde, em qualquer área de atuação, não basta apenas desenvolver a sua habilidade técnica. A capacitação interacional desse profissional também se faz necessária para reconhecer e lidar com os aspectos subjetivos do individuo. Daí a importância de se reinterpretar o risco quando se resgata o discurso materno sobre a experiência da morte perinatal.

Diante disso, como lidar com as dificuldades e os conflitos narrados pelas entrevistadas, como abordar os aspectos do elo rompido da relação entre 
profissionais de saúde-paciente - tornados mais complexos quando o pré-natal é realizado por um médico, a admissão hospitalar para o parto por outro, o parto por um terceiro, e a alta por um quarto, como pudemos constatar no grosso das narrativas apresentadas.

Segundo COSTA (2002), "Esse 'rodizio' de profissionais em torno de uma mesma gravidez gera medo e insegurança entre as pacientes". (p.31).

De tudo o que foi exposto até aqui, somos induzidos a pensar que a noção de evitabilidade da morte parece mediar a relação entre o risco enquanto discurso com fins de aplicação na clínica e programas de prevenção e a prática assistencial como ela se apresenta. 


\section{Considerações finais}

Podemos pensar a relevância dessa investigação encarando-a como condição de possibilidade para iluminar a discussão em torno do debate sobre a morte perinatal.

Para isso, partimos de questões que permitissem dar maior visibilidade ao enunciado e julgamento das mulheres nas experiências da perda do filho no período perinatal, a percepção dessas mulheres sobre a evitabilidade da morte, e ao feitio assumido pela noção de risco na interface entre os discursos clínico-epidemiológico e materno em face da consumação da perda.

Na aproximação com a problemática descrita percorreu-se os seguintes passos: fez-se o reconhecimento da morte perinatal enquanto um problema de saúde pública de grande relevância; procedeu-se à análise do enfoque de risco e suas aplicações na clinica e epidemiologia; identificou-se as nove mulheres da pesquisa no que toca às suas relações sociais e familiares, crenças e religiosidade; demarcou-se o contexto da experiência da perda no âmbito do processo reprodutivo feminino, da assistência e da interação com o serviço e profissionais de saúde; enveredou-se na busca da explicação materna para a perda e o que poderia tê-la evitado. Finalmente, tentou-se realizar uma síntese compreensiva entre discursos teóricos (técnico-científico) e empíricos (narrativas).

Dessa forma, a ordenação interna do conjunto apresentou uma configuração de base apoiada em três eixos centrais de produções discursivas, geradoras de sentido: a) ao falar da morte do filho a mulher estabelece relação com o serviço de saúde; b) ao falar da assistência durante a gestação e parto a noção de risco emerge com 
múltiplos significados; c) ao falar sobre a evitabilidade da morte a idéia de risco aparece vinculada a noção de causalidade.

Com efeito, esse percurso desaguou numa sintese na qual se pôde constatar que a noção de risco, na situação concreta da perda, não tem a mesma feição contemplada pelo discurso clínico-epidemiológico do risco. O olhar tomado a partir da experiência da perda expõe o risco em uma outra dimensão, o risco corporificado em um conjunto de circunstâncias relativamente à gestação e parto, reveladas através do julgamento sobre o acontecimento, compreendendo particularidades, contexto, historicidade, inter-relações entre singularidades.

A causalidade e evitabilidade da morte emergem no discurso das mulheres como categorias localizadas no foco da assistência recebida, no âmbito das relações assistenciais (relação instituição-usuário; profissionais de saúde-paciente), durante a gravidez e no momento do parto.

No cerne dessas considerações pode-se concluir que o conjunto de acontecimentos indesejáveis e de omissões nas instâncias assistenciais (violência institucional) possam ter contribuido para falhas irreversíveis implicadas na perda perinatal, potencialmente evitáveis, ocorridas ao longo da peregrinação da mulher na sua busca de atenção e cuidados, compatíveis com a sua necessidade (risco institucional).

Inclino-me a considerar que os casos analisados são expressão da morte como um fato social. Como fenômenos sociais inseridos no campo da saúde e do direito reprodutivo e da cidadania, e como tal deve ser lido.

A contribuição do método para a pesquisa pôde ser verificada em três planos: 1) No plano individual, pela oportunidade de a mulher (re)significar a sua 
experiência - o resgate da experiência e a sua (re) significação demonstrou ser uma peculiaridade relevante da aplicação do método qualitativo na presente investigação. 2) No plano ético, esse estudo atingiu um lugar privilegiado, pois, ao mesmo tempo em que proporcionou sentido à experiência, também pareceu ter-se convertido em algum beneficio para a mulher, suprindo, em parte, as possíveis distorções decorrentes da escolha feita do local das entrevistas (hospital). 3) No plano de aplicação, o método utilizado demonstrou ser útil como instrumento auxiliar na formulação de políticas, como instrumento complementar ao método quantitativo - já que as políticas são, em geral planejadas apenas com base em indicadores epidemiológicos. Aqui, não se trata de considerar um método melhor ou pior do que o outro, mas apenas chamar atenção para os limites impostos por ambos os métodos, quando colocados de forma isolada.

Pelo exposto, a instituição da ação política na direção da saúde reprodutiva como um direito, e como parte integrante do desenvolvimento humano e social, torna-se essencial para redução dos elevados índices de mortalidade materna e perinatal verificados no Brasil. Nesta perspectiva a ação se volta para o atendimento integral da gestante, conferindo-a: atendimento pré-natal de qualidade (com a valorização de aspectos de sua particularidade física e emocional; auxílio, apoio e confiança necessários à condução de uma maior autonomia da mulher na gestação e no parto); promoção do parto e nascimento humanizados e sem complicações. A garantia de um sistema eficiente de referência e contra-referência, objetivando a continuidade da assistência pré-natal em todos os niveis de complexidade do sistema de saúde para toda a clientela, conforme a exigência de cada caso, assegurando o seu 
retorno à unidade básica de origem, com todas as informações necessárias para o seguimento do pré-natal.

Espera-se que este trabalho possa de alguma forma inspirar a realização de outros estudos que venham a esclarecer a grave situação da saúde da mulher e da criança no período da gestação e parto.

Espera-se ainda que toda e qualquer mulher ao procurar o Serviço de Saúde possa ser ouvida em sua singularidade, na sua diferença e não dentro de uma visão de suposta igualdade, uniformidade. Uma diferenciação do olhar e da escuta para cada mulher.

Por fim, (re) visitar a noção de risco de morte perinatal, à luz da percepção materna sobre a experiência da perda, possibilitou reforçar o debate em torno do método. Permitiu evidenciar que o enfoque de risco é importante, mas insuficiente no plano explicativo do complexo evento da morte perinatal. O enfoque na sua forma explicativa é possuído de um grau de abstração que se distancia muito da experiência humana. 


\section{REFERÊNCIAS BIBLIOGRÁFICAS}

ABBAGNANO N. Dicionário de Filosofia. $4^{\mathrm{a}}$ ed. São Paulo, Martins fontes, 2000

ALMEIDA FILHO N. Epidemiologia sem números: uma introdução crítica à ciência epidemiológica. Rio de Janeiro. Campos, 1989.

ALMEIDA FILHO N. A. Clínica e a Epidemiologia. 2.ed. Salvador, APCEABRASCO. 1997.

ALMEIDA MF, MELLO JORGE MHP. Pequenos para idade gestacional: fator de risco para mortalidade neonatal. Rev. Saúde Públ., 32(3):217-24, 1998.

ALMEIDA MF, NOVAES HMD, MONTERO CV. Análise da Tendência da Mortalidade Infantil no Município de São Paulo. In: Congresso Brasileiro de Epidemiologia, 4, Rio de Janeiro, 1998. Livro de Resumos. Rio de Janeiro, 1998. p.38-39. (Comunicações Coordenadas, 23-77)

ALVARENGA AT. O enfoque de risco. In: Il seminário Estadual de Saúde da Criança; 1986 dez 2-5; São Paulo, Brasil. São Paulo: Secretaria de Estado da Saúde; 1987.

ALVARENGA AT. O conceito de risco gravídico e a questão perinatal. In: Anais do "I Simpósio Franco-Brasileiro de Metodologias em Pesquisa em Saúde Perinatal". Universidade de São Paulo. Faculdade de Saúde Pública, Departamento de Saúde Materno-Infantil. São Paulo, Brasil. São Paulo: Secretaria de Estado da Saúde; Série de Investigação em Saúde da Mulher, da Criança e Adolescência, 3:29-39, 1994.

ANDRADE CJM, PAIXÃO H, MODENA C, TORRES AMC. Representações de saúde-doença de um grupo de mulheres residentes em bairros da periferia de Belo Horizonte (1994-1996). Rev. Brás. Cresc. Densenv. Hum. 7(1):20-33, 1997.

ÁVILA, M.B., GOUVEIA, T. - Notas sobre Direitos Reprodutivos e Direitos Sexuais. In: PARKER, R., BARBOSA, R.M. (orgs.). Sexualidades Brasileiras. Rio de Janeiro: Dumaré: ABIA: IMS: UERJ, 1996

ARIĖS P. História Social da Criança e da Família. $2^{\text {a }}$ edição. Rio de Janeiro, Zahar Editores. 1981.

ARIÈS P. O homem diante da morte. (V. I). Rio de Janeiro, Francisco Alves, 1981.

ARIÈS P. O homem diante da morte. (V. II). Rio de Janeiro, Francisco Alves, 1982.

AYRES JRCM. Sobre o Risco: Para Compreender a Epidemiologia. São Paulo. HUCITEC. 1997.

AYRES JRCM, JUNIOR IF, CALAZANS GJ, FILHO HCS. Vulnerabilidade e prevenção em tempo de AIDS. In: BARBOSA RM, PARKER E. Sexualidade pelo avesso: direitos identidade e poder. Rio de Janeiro. IMS/UERJ. 1999. 
BACKETT EM, DAVIES AM, PETROS-BARVAZIAN A. O Enfoque de Risco na Assistência à Saúde: Com especial referência à saúde materno-infantil, inclusive planejamento familiar. Washington, OMS/OPS, 1985. [Publicação Científica № 491]

RADINTER E. Um Amor conquistado: o mito do amor materno. Rio de Janeiro, Nova Fronteira, 1985.

BALDIJÃO MF, MELLO JORGE MHP. Óbitos fetais no Brasil no período de 1980 a 1985: Análise de informação disponivel no Ministério da Saúde. Centro da OMS para a Classificação de Doenças em Português. São Paulo, 1989.

BARBOSA R.M., PARKER, R. - Sexualidades pelo Avesso: Direitos, identidades e poder. Rio de Janeiro: IMS/UERJ; São Paulo:Ed.:34, 1999.

BARDIN L. Análise de conteúdo. Lisboa, Edições 70 Lda, 2000.

BLANCHET A, GOTMAN A. Análise dos Discursos. In: A enquête e seus Métodos: a entrevista. [Tradução Greice Menezes]. Éditions Nathan: Paris, 1992. (Cópia xerografada).

BOFF L. Saber cuidar: ética do humano-compaixão pela terra. Petrópolis, Rio de Janeiro, Vozes, 1999.

BOLTANSKI L. As classes sociais e o corpo. $2^{\text {a }}$ ed. Rio de Janeiro, Edições Graal, 1984.

BOWLBY J. Apego e perda: tristeza e depressão. V.3; $2^{\text {a }}$ ed. São Paulo, Martins Fontes, 1998.

BRASIL. MINISTÉRIO DA SAÚDE. SECRETARIA NACIONAL DE ASSISTENNCIA Ȧ SAÚDE. DEPARTAMENTO DE PROGRAMAS DE SAÚDE. DIVISÃO NACIONAL DE SAÚDE MATERNO-INFANTIL. PROGRAMA DE ASSISTÊNCIA INTEGRAL À SAÚDE DA MULHER (PAISM). Gestação de Alto Risco: Normas e Manuais Técnicos. Brasília, 1991.

BRASIL. MINISTÉRIO DA SAÚDE. SECRETARIA DE POLÍTICAS DE SAÚDE. DEPARTAMENTO DE GESTÃO DE POLÍTICAS ESTRATÉGICAS. ÁREA TÉCNICA DE SAÚDE DA MULHER. Gestação de Alto Risco: Manual Técnico. $3^{\mathrm{a}}$ ed. Brasilia, 2000a.[on line]

BRASIL. MINISTÉRIO DA SAÚdE. SECRETARIA EXECUTIVA. Programa Humanização do Parto: humanização no pré-natal e nascimento. Ministério da Saúde. Secretaria Executiva. Brasília, Ministério da Saúde. 2000b. [on line]

BRASIL. MINISTÉRIO DA SAÚDE. Assistência Pré-natal. Manual técnico. Brasilia, 2000c. http://www.ufes.br/ dgo/prenatal.htm 
BRASIL. MINISTÉRIO DA SAÚDE. SECRETARIA EXECUTIVA. Gestante de Alto Risco: Sistema estadual de referência hospitalar à gestante de alto risco. Ministério da Saúde. Secretaria Executiva. Brasília. Ministério da Saúde. 2001 [on line]

BRIOSCHI L, TRIGO MH. Relatos de vida em ciências sociais: considerações metodológicas. Ciência e Cultura, 39(7): 631-637, 1987.

BROMBERG MHPF, KOVÁCS MJ, CARVALHO MMMJ, CARVALHO VA. Vida e Morte: Laços da Existência. São Paulo, Casa do Psicólogo, 1996.

BUENO E, GOID A, NESRALLA I, MACHADO JAP, MARTINS L, FIORILLO M et al. Prazeres e Riscos. Porto Alegre, Rio de Janeiro, São Paulo, L\&PM Editores, 2001 .

CASTIEL LD. A medida do possível... saúde, risco e tecnobiociências. Rio de Janeiro: Contra Capa Livraria/Editora. FIOCRUZ, 1999.

CEBRIAN SR. Glossario de Economia de la Salud (y Disciplinas Afines). España: Ediciones Diaz de Santos, S.A.; 1995.

CHAUI M. Senso comum e transparência. In: O preconceito. Secretaria da Justiça e da Defesa da Cidadania. Governo do Estado de São Paulo. 1996/1997. São Paulo, ed. Julio Lerner. (p.115-133). (cópia xerográfica).

CHAUI M. Convite à filosofia. São Paulo, Editora Ática. 12 ${ }^{\mathrm{a}} \mathrm{ed} ., 2001$.

COSTA SIF. Conflito materno-fetal. SER Médico. 18: 30-31 2002. [CREMESP].

DENZIN NK, LINCOLN YS. Entering the Field of Qualitative Research.[Introduction]. In: Handbook of Qualitative Research. International Educational and Professional Publisher. Thousand Oaks, London, New Delhi, SAGE Publications. 1994.

FARIA N. NOBRE M. Gênero e Desigualdade. São Paulo, SOF. 1997.

FERREIRA ABH. Novo Aurélio Século XXI: O dicionário da língua portuguesa. 3ed. Rio de Janeiro: Nova Fronteira, 1999.

FLETCHER H. FLETCHER SW, WAGNER ED. Epidemiologia Clínica: Elementos Essenciais. $3^{\mathrm{a}}$ ed. Trad.: Bruce B. Duncan e Maria Inês Schmidt. Porto Alegre: Artes Médicas; 1996.

FREITAS CM. GOMEZ CM. Análise de riscos tecnológicos na perspectiva das ciências sociais. História, Ciências, Saúde - Manguinhos, III(3):485-504, 19961997. http://www. fiocruz.br/hscience

FREITAS NK. Luto Materno e Psicoterapia Breve.São Paulo, Summus. 2000. 
GIDDENS A. As Conseqüências da Modernidade. São Paulo: Editora da Universidade Estadual Paulista, 1991.

GUALDA DMR. O significado do Processo de parto no contexto do conceito de saúde reprodutiva. In: CIANCIARULLO TI, GUALDA DMR, MELLEIRO MM. C \& Q: Indicadores de Qualidade: uma abordagem perinatal. São Paulo, İcone, 1998.

HAGUETTE TMF. Metodologias Qualitativas na Sociologia. 6.ed. Petrópolis, Editora Vozes, 1999.

KALUME AG, JOAQUIM MMC, SIU C. Mortalidade perinatal e neonatal no Brasil. Ministério da Saúde do Brasil/UNICEF-Brasil. Colaboradores: KALUME P, CASTILLO O, LEAL M.C. Ministério da Saúde do Brasil/UNICEF-Nova Iorque/FIOCRUZ/Ministério da Saúde do Brasil. Tema (17): 1999.

KAVOO-LINGE, ROGO K. O. Factors Influencing early perinatal mortality in a rural district hospital. East African Medical Journal. 69(4): 181-187 1992.

KITZINGER S. Mães: um estudo antropológico da maternidade. $2^{a}$ ed. Lisboa, Editorial Presença, 1996.

LALANDE A. Vocabulário técnico e crítico da filosofia. $3^{\text {a }}$ ed. São Paulo, Martins Fontes, 1999.

LANNES R. Assistência perinatal e neonatal no Brasil: Um desafio para os Serviços de Saúde. Responsabilidade partilhada. O papel das instâncias do SUS na Organização da Assistência Perinatal. Ministério da Saúde do Brasil/UNICEFBrasil. Colaboradores: KALUME P, CASTILLO O, LEAL M.C. Ministério da Saúde do Brasil/UNICEF-Nova Iorque/FIOCRUZ/Ministério da Saúde do Brasil. Tema (17):1999. http://www.ensp.fiocruz.br/publi/radis/temal 7.html

LEITE AJM. SOUZA LCB. SILVA AVS, BORGES JC, SÁ HLC. Saúde Perinatal no Município de Fortaleza, Ceará, 1995. Secretaria Estadual da Saúde do Ceará. 1997.

LEPARGNEUR H. O doente, a doença e a morte: implicações socioculturais da enfermidade. Campinas, Papirus, 1987.

KOVÁCS MJ. Morte e desenvolvimento humano. São Paulo, Casa do Psicólogo, 1992.

LAST JM. A Dictionary of Epidemiology. New York/Oxford/Toronto, Oxford University Press, 1995.

LAURENTI R, MELLO JORGE MHP. O Atestado de Óbito. Centro da OMS para a Classificação de Doenças em Português. São Paulo, 1996.

LEAL MC, SZWARCWALD CL. Evolução da mortalidade neonatal no Estado do Rio de Janeiro. Brasil (1979-1993): análise por causa segundo grupo de idade e região de residência. Cad. Saúde Públ. 12(2):243-252, 1996. 
LEITE JAM. Saúde perinatal no Município de Fortaleza, Ceará, 1995. Secretaria Estadual da Saúde do Ceará/Programa Viva Criança - Ação Perinatal/Escola de Saúde Pública do Ceará/Faculdade de medicina - UFC/Departamento de Saúde Materno-Infantil, 1997.

MARANHÃO AGK, JOAAQUIM MMC, SIU C. A mortalidade perinatal e neotal no Brasil. Fórum sobre mortalidade. Fórum sob.assist.per. Brasilia, Brasil, Julho de 1998.

MARQUES JA, DUARTE MF. Gravidez. São Paulo: Contexto; 1998.

MARTIN DA. Construção Cultural do Risco: o cotidiano da prostituição em Santos. São Paulo, 1999. [Tese de Doutorado - Faculdade de Filosofia, Letras e Ciências Humanas/ Universidade de São Paulo].

MARTINS JS. A morte e os mortos na sociedade brasileira. São Paulo, HUCITEC, 1983.

MARTINS AM, QUAYLE J, SOUZA, MC, ZUGAIB M. O impacto emocional materno diante da perda fetal durante a gestação: aspectos qualitativos. Rev. Ginec. \& obstet., 9(3):153-159, 1998.

MARTINS MCFN. Humanização das relações assistenciais: a formação do profissional de saúde. São Paulo, Casa do Psicólogo, 2001.

MARTINS MCFN. Humanização na saúde: Relação médico-paciente no microscópio. SER Médico. 18: 27-29, 2002. [CREMESP].

MENEZES AMB, BARROS FC, VICTORA CG, ALVES C, ROCHA C, ALBERNAZ E, MENEZES FS, JANNKE HA. Mortalidade perinatal em duas coortes de base populacional no Sul do Brasil: tendências e diferenciais. Cad. Saúde Públ. 12 (supl.1):33-41, 1996.

MINAYO MCS. O Desafio do Conhecimento: Pesquisa Qualitativa em Saúde. São Paulo-Rio de Janeiro: Hucitec-Abrasco, 1992.

MINAYO MCS. Interdisciplinaridade: Funcionalidade ou Utopia. Saúde e Sociedade. 3 (2): 42-63, 1994.

MINAYO MCS. Prefácio. In: NOGUEIRA MI. Assistência Pré-natal: prática de saúde a serviço da vida. São Paulo, Editora HUCITEC, 1994.

MINAYO MCS. Ciência, Técnica e Arte: O Desafio da Pesquisa Social. In: DESLANDES SF. NETO OC. GOMES R. Pesquisa Social: Teoria, Método e Criatividade. 13.ed. MINAYO, M.C.S. (Org). Vozes Editoras, Petrópolis, 1999.

MORIN E. O Desafio da Complexidade. In: . Ciência com Consciência. Mem Martins. Europa-America, 1994.

NOGUEIRA O. Morte e faixa etária: os anjinhos. In: MARTINS JS. (Org.). A morte e os mortos na sociedade brasileira. São Paulo, HUCITEC Editora, 1983. 
NOGUEIRA MI. Assistência Pré-natal: prática de saúde a serviço da vida. São Paulo, Editora HUCITEC, 1994. 155p.

NOVAES RR. Os crentes: razões para viver e morrer. In: MARTINS JS. A morte e os mortos na sociedade brasileira. São Paulo, HUCITEC, 1983.

ORGANIZAÇÃO MUNDIAL DA SAÚDE. Metodo de Atencion Sanitaria de La Madre y el Niño Basado en el Concepto de Riesgo. Genebra, OMS, 1978a, 45p. (Publicación, 39)

ORGANIZAÇÃO MUNDIAL DA SAÚdE. Alma-Ata 1978 - Primary Health Care. Genebra, OMS, 1978.

ORGANIZAÇÃO MUNDIAL DA SAÚDE. Classificação Estatística Internacional de Doenças e Problemas Relacionados à Saúde. $10^{\underline{a}}$ Revisão. Centro da OMS para a Classificação de Doenças em Português. São Paulo, 1996.

OSAVA RH, MAMEDE MV. A assistência ao parto ontem e hoje: a representação social do parto. J Bras. Ginec. (1/2):3-9, 1995.

OSIS MJMD. Paism: um marco na abordagem da saúde reprodutiva no Brasil. Cad. Saúde Públ, 14(supl.1):25-32,1998.

PINKUS L. A família e a morte: como enfrentar o luto. Rio de Janeiro: Paz e Terra; 1989.

PLAUT R. Analisis de riesgo. Alcance y limitaciones para el administrador de salud. Bol. Of Sanit Panam. 96(4):296-306, 1984.

POPIM RC, BARBIERI A. O significado da morte perinatal - Depoimento de mães. R. Bras. Enferm. 43:134-140, 1999.

QUEIROZ MIP. Variações sobre a técnica de gravador no registro da informação viva. São Paulo: T.A. Queiroz, 1991.

ROGÉRIO L. Mortalidade perinatal e neonatal no Brasil. Ministério da Saúde do Brasil/UNICEF-Brasil. Colaboradores: KALUME P, CASTILLO O, LEAL MC. Ministério da Saúde do Brasil/UNICEF-Nova Iorque/FIOCRUZ/Ministério da Saúde do Brasil. Tema (17): 1999.

ROSA MLG, HORTALE VA. Óbitos perinatais evitáveis e estrutura de atendimento obstétrico na rede pública: estudo de caso em município da Região Metropolitana do Rio de Janeiro. Cad. Saúde Pública 16(3): 2000. [on line]

ROSA MLG, HORTALE VA. Óbitos perinatais evitáveis e ambiente externo ao sistema de assistência: estudo de caso em município da Região Metropolitana do Rio de Janeiro. Cad. Saúde Pública 18(3): 2002. [on line]

SANTOS ALD. História das perdas fetais contadas por mulheres. Universidade de São Paulo/Faculdade de Saúde Pública/Departamento de Saúde Materno-Infantil. Projeto de Pesquisa, 1999. 
SCAVONE, L. - Anticoncepción, aborto y tecnologias conceptivas: entre la salud, la ética y los derechos. In: . (orgs.). - Género y Salud Reproductiva en America Latina. Cartago:Libro Universitario Regional, 1999.

SCHILLER P. Diagnóstico do bom-senso. Médico em Foco. CREMESP, Ser Médico. [s/d. Cópia xerografada].

SIQUEIRA AAF, SANTOS JLF, SILVA JF. Relação entre estado nutricional da gestante, fumo durante a gravidez, crescimento fetal e no primeiro ano de vida. Rev Saúde Públ., 20(6):421-34, 1986.

SIQUEIRA AAF. Aspectos perinatais. In: Anais do "I Simpósio Franco-Brasileiro de Metodologias em Pesquisa em Saúde Perinatal". Universidade de São Paulo. Faculdade de Saúde Pública, Departamento de Saúde Materno-Infantil. São Paulo, Brasil. São Paulo: Secretaria de Estado da Saúde; Série de Investigação em Saúde da Mulher, da Criança e Adolescência, 3:41-44, 1994a.

SOUZA MLR. Os diferentes discursos na instituição hospitalar. Percurso 23(2), 1999. http://www.uol.com.br/percurso/ [on line].

SIQUEIRA AAF. Mortalidade perinatal. In: Anais do "I Simpósio Franco-Brasileiro de Metodologias em Pesquisa em Saúde Perinatal". Universidade de São Paulo. Faculdade de Saúde Pública, Departamento de Saúde Materno-Infantil. São Paulo, Brasil. São Paulo: Secretaria de Estado da Saúde; Série de Investigação em Saúde da Mulher, da Criança e Adolescência, 3:117, 1994 b.

SPINK MJP. (org). Práticas Discursivas e Produção de Sentido no Cotidiano: Aproximações teóricas e metodológicas. São Paulo, Cortez Editora, $2^{a}$ ed. 2000.

SPINK MJP, MENEGON VM. A Pesquisa como prática discursiva: superando os horrores metodológicos. In: SPINK MJP (org.). Práticas Discursivas e Produção de Sentido no Cotidiano: Aproximações teóricas e metodológicas. São Paulo, Cortez Editora, $2^{a}$ ed. 2000.

TANAKA ACd'A. Estatísticas de mortalidade perinatal. In: Anais do "I Simpósio Franco-Brasileiro de Metodologias em Pesquisa em Saúde Perinatal". Universidade de São Paulo. Faculdade de Saúde Pública, Departamento de Saúde Materno-Infantil. São Paulo, Brasil. São Paulo: Secretaria de Estado da Saúde; Série de Investigação em Saúde da Mulher, da Criança e Adolescência, 3:13-20, 1994.

TANAKA ACd'A. Maternidade: dilema entre nascimento e morte. São PauloRio de Janeiro, HUCITEC/ABRASCO, 1995.

TANAKA ACd'A. Saúde da mulher brasileira. In: CIANCIARULLO TI, GUALDA DMR, MELLEIRO MM. C \& Q: Indicadores de Qualidade: uma abordagem perinatal. São Paulo, Ícone, 1998.

TEDESCO JJ. Aspectos emocionais da gravidez de alto risco. In: ZUGAIB M, TEDESCO JJ, QUAYLE J. Obstetrícia psicossomática. São Paulo, Atheneu, 1997. 
TEMA/RADIS/ENSP/FIOCRUZ. Assistência Perinatal e Neonatal no Brasil: Um Desafio para os Serviços de Saúde. RADIS/ENSP/FIOCRUZ. Tema (17):1999. http://www.ensp.fiocruz.br/publi/radis/tema17.html

UNGERER R. Situação perinatal no mundo. In: Mortalidade perinatal e neonatal no Brasil. Ministério da Saúde do Brasil/UNICEF-Brasil. Colaboradores: KALUME P, CASTILLO O, LEAL M.C. Ministério da Saúde do Brasil/UNICEF-Nova Iorque/FIOCRUZ/Ministério da Saúde do Brasil. Tema (17):1999. http://www.ensp.fiocruz.br/publi/radis/temal 7.html

VOLICH RM. Entre uma angústia e outra. Psicanálise e Doenças Terminais. Livraria Pulsional, Boletim de novidades, № $80,1995$. 


\section{Anexos:}

Anexo I: Declaração de Óbito

Anexo 2: Carta convite às mães

Anexo 3: Declaração de Aprovação do Comitê de Ética

Anexo 4: Termo de Consentimento

Anexo 5: Roteiro da entrevista

Anexo 6: Matriz temática

Anexo 7: Recortes por entrevista

Anexo 8: Matriz de análise

Anexo 9: Matriz de análise das entrevistas

Anexo 10: Classificação de Redutibilidade dos Óbitos Neonatais 


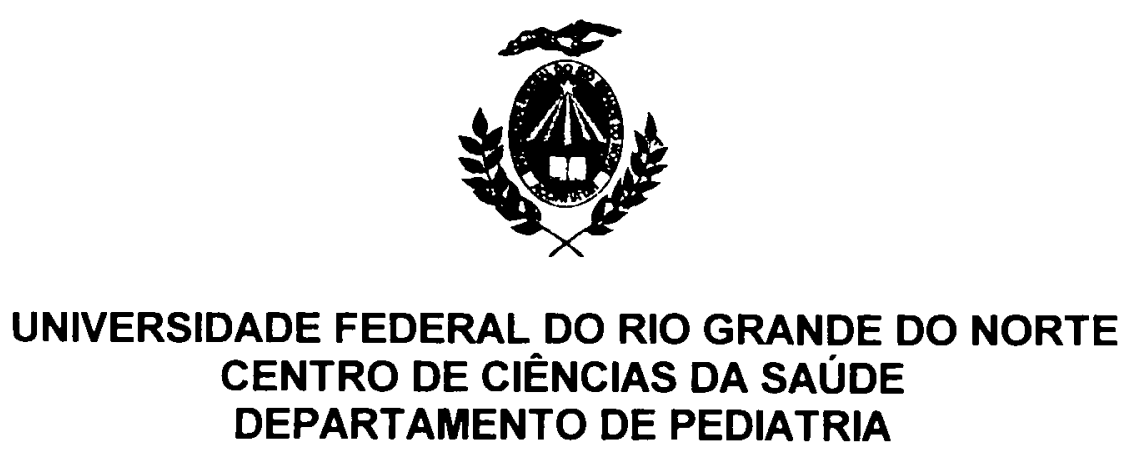

\section{CONVITE}

Sra.

venho

através deste convite solicitar a sua presença no dia de agosto de 2001, às horas, no Hospital (Departamento) de Pediatria da UFRN, localizado à rua General Gustavo Cordeiro de Faria s/n, Petrópolis (por trás da Maternidade Januário (icco), nesta cidade, a fim de participar de uma entrevista com a Dra. Jozana do Rosário de Moura Caetano, médica e professora do referido Hospital (Departamento).

Informo que essa entrevista faz parte de uma pesquisa realizada pela mencionada professora e que a sua participação trará uma valiosa colaboração ao desenvolvimento dos trabalhos oferecidos por essa e por outras Instituições de saúde.

Caso deseje atender ao nosso convite e participar da pesquisa, solicitamos que, ao chegar ao Hospital, a senhora se dirija à Recepção, localizada na entrada principal, trazendo esta carta de identificação, a fim de ser encaminhada à sala da Diretoria de Atividades Assistenciais, do já mencionado Hospital, no dia e horário marcados.

Atenciosamente,

Jozana do Rosário de Moura Caetano

Natal, de julho de 2001

Jozana do Rosário de Moura Caetano.

Hospital e Departamento de Pediatria da UFRN.

$R$. Gen. Gustavo Condeiro de Faria, $s / n$.

Petropolis- Natal.

Fone: $215-4317$ 


\section{UNIVERSIDADE DE SÃO PAULO \\ FACULDADE DE SAÚDE PÚBLICA \\ COMITÉ DE ÉTICA EM PESQUISA-COEP \\ Av. Dr Arnaldo, 715 - sala 18 - sub-solo - Cerqueira Cesar \\ Sào paulo-sP CEP: 01246-904 \\ Telefone (0XX11) 3066-7776 - e-mail: mogracaseusp.br}

Of.COEP/138/00

11 de setembro de 2000

Pelo presente, informo que o Comitê de Ética em Pesquisa da Faculdade de Saúde Pública da Universidade de São Paulo-COEP, analisou e aprovou, de acordo com os requisitos da Resolução CNS/196/96, o protocolo de pesquisa n ${ }^{\circ} 294$, intitulado: "O RISCO NEONATAL (RE)VISITADO: UM ESTUDO DA PERCEPÇ̃̃O MATERNA DA MORTE NEONATAL", apresentado pela pesquisadora Jozana do Rosário de Moura Caetano.

Atenciosamente,

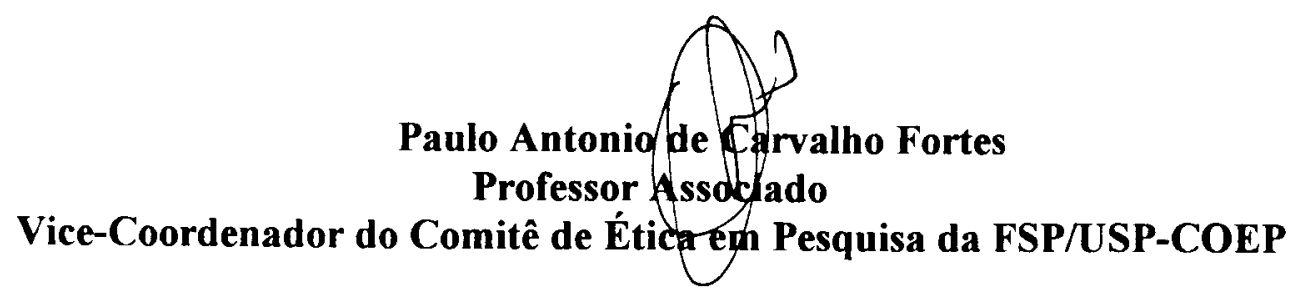




\title{
ANEXO 4 \\ TERMO DE CONSENTIMENTO
}

\author{
Título da Pesquisa: “O Risco Perinatal (Re)visitado: Um estudo da percepção materna da \\ morle neonatal".
}

A pesquisa que vamos realizar, faz parte da dissertação de doutorado do Curso de Pós-Graduação da Faculdade de Saúde Pública da Universidade de São Paulo. Para tanto, estamos solicitando a sua valiosa colaboração no sentido de responder algumas perguntas sobre a sua última gravidez e parto. e sobre as condições de nascimento. adoecimento e morte do seu filho. Esta pesquisa é muito importante para que as pessoas, especialistas ou não no assunto, profissionais e administradores das instituições de saúde, possam dedicar uma maior atenção ao tema e olhar de forma mais humanitária para este problema.

A história que a senhora vai nos contar diz respeito aos acontecimentos e as experiências vividas por ocasião da sua gestação e parto, dos problemas relacionados à sua saúde e do seu filho nos primeiros dias de vida e em relação à morte da criança. Esta informação não apenas vai nos ajudar a entender melhor todos os problemas relatados pela senhora, como também vai permitir que possamos fazer algumas propostas de ação visando diminui-los ou amenizá-los.

Portanto, convidamos a senhora para participar da entrevista, que vai ocupar apenas um pouco do seu tempo. Pedimos a sua permissão para gravá-la pois assim poderemos fazer um registro fiel do que nos for contado pela senhora.

Comprometemo-nos a não divulgar o seu nome e que, assim que terminarmos o nosso trabalho. retornaremos para a senhora com tudo o que escrevemos. De antemão, garantimos que a sua participação neste estudo é livre e voluntária, e que, em qualquer momento da entrevista, a senhora poderá desistir. Asseguramos que esta participação não trará quaisquer riscos, constrangimentos e desconfortos a sua pessoa ou a seus familiares.

Durante o desenrolar da entrevista estaremos à disposição para os esclarecimentos que forem necessários, seja do modo como a gente vai trabalhar, seja do conteúdo e dos objetivos da pesquisa. Esta pesquisa não implica em despesas da parte do entrevistado.

Desde já, agradecemos a sua importante colaboração.

Natal, .... de de 2001 .

Jozana do Rosário de Moura Caetano. Pesquisador responsável

Nome do entrevistado

Pesquisador responsável: Jozana do Rosário de Moura Caetano. Faculdade de Saúde Pública. Departamento de Saúde Matemo Infantil. Rua Dr. Arnaldo, 715, Sảo Paulo - SP. Telefone: (11) 30667702 , $30667703,5493020$.

Orientador da Pesquisa: Prof. Amaldo Augusto Franco de Siqueira. Faculdade de Saúde Pública Departamento de Saúde Materno Infantil. Rua Dr. Arnaldo, 715, Sảo Paulo - SP. Telefone: (11) 30667702 (11) 30667703 


\section{ANEXO 5 \\ ROTEIRO DA ENTREVISTA}
O RISCO PERINATAL (RE) VISITADO: Um estudo da percepção materna da morte perinatal

\section{IDENTIFICAÇÃO}

Nome:

Código: (corresponde ao número de ordem da entrevista)

Idade: anos.

Endereço: (Natal)

Profissão:

Trabalho:

Local:

Escolaridade: (Grau)

Situação conjugal:

Escolaridade do companheiro:

Profissão:

Trabalho do companheiro:

Idade do companheiro:

Religião:

\section{PERCEPÇÃO MATERNA DA PERDA DO FILHO}

\section{A Morte do bebê}

- Relato da experiência da perda

- Como aconteceu a perda do bebê

- Como soube da morte do bebê

\section{Percepção da morte}

- Explicação da morte - Explicação materna e (re)tradução da explicação fornecida pelos profissionais de saúde)

- O que poderia ter evitado a morte do bebê

- Alguém ou o quê poderia ter sido feito para impedir a ocorrência da morte

\section{- HISTÓRIA REPRODUTIVA FEMININA}

- Concepção

- Gestação

- Parto

Percepção da assistência (Mulher e recém-nascido)

- Assistência pré-natal

- Assistência ao parto

- Assistência ao recém-nascido 


\section{$\underline{\text { Antecedentes }}$}

- Obstétricos;

- Pessoais e ginecológicos;

- Familiares (Doenças na família, perdas na família).

\section{- ESTRUTURAÇÃO E CONTEXTO SOCIAL E FAMILIAR}

- Situação conjugal e familiar

- Informações sobre o companheiro

- Informações sobre ascendentes familiares

- Comportamento materno e religiosidade

- Informações sobre o companheiro

- Relações sociais e familiares (Maternidade e paternidade) 


\section{ANEXO 6 \\ MATRIZ TEMÁTICA}

O RISCO PERINATAL (RE) VISITADO: Um estudo da percepção materna da morte perinatal

DECOMPOSIÇÃO DO TEXTO POR TEMAS (identificados por cores)

Entrevista $\mathbf{n}^{\mathbf{0}}$ 00

Data:

Hora - Início/Término:

Entrevistada:

Entrevistadora: Jozana do Rosário de Moura Caetano.

TEMAS E ÍNDICES TEMÁTICOS

ENTREVISTAS

\section{A. IDENTIFICAÇÃO • violeta.}

- Nome:

- Código: (corresponde ao número de ordem da entrevista)

- Idade: anos.

- Endereço: (Natal)

- Trabalho fora de casa:

- Local:

- Escolaridade: (Grau)

- Cursos:

- Situação conjugal:

- Escolaridade do companheiro:

- Profissão:

- Trabalho do companheiro:

- Idade do companheiro:

- Religião: 


\section{B. PERCEPÇÃO MATERNA DA MORTE}

\section{A. PERCEPÇÃO MATERNA DA PERDA DO FILHO • vermelho escuro.}

\section{1) A morte do bebê:}

- A experiência da morte

- Como aconteceu a morte do bebê

- Como foi informada da morte do bebê

- Quem informou sobre a morte

- A explicação da equipe de saúde sobre a morte

- Reação quando soube da morte

- Atitude em relação ao natimorto

- Necropsia e sepultamento

- Atestado de óbito

- Diagnóstico

- Expectativa em relação à outra gravidez.

2) Percepcão da morte e luto:

- O que poderia ter evitado a morte

- A explicação materna da morte

- Atitude diante da morte

- Reação da família diante da morte

- O significado da perda

- Comportamento e religiosidade

- Mecanismos para o enfrentamento da morte;

- Sentimentos em relação à morte

- Culpa;

- Conformismo;

- Ajustamento;

- Mecanismos de elaboração da perda 


\section{C [1] HISTÓRIA REPRODUTIVA FEMININA}

I. CONCEPÇÃO: • verde

II. GESTAÇÃO: \ amarelo

- Como aconteceu a gravidez

- Confirmação da gravidez

- Sentimentos e atitude diante da gravidez

- A gestação foi desejada

- Planejamento da gravidez

- Reação do companheiro

- Contracepção anterior

1) Percepcão da gestação:

- Trajetória da gravidez

- Problemas na gestação

- Percepção dos problemas na gravidez

Percepção dos movimentos fetais

- Percepção de risco (perigo, ameaça) na gravidez.

- Comportamento materno durante a gravidez

- Atitude frente os problemas na gravidez - O cuidado de si e do outro (bebê)

- A percepção do corpo grávido

- Expectativas em relação ao filho

- O sexo da criança

- Duração da gestação.

- A relação com o companheiro

- A relação com outros familiares

III. PARTO • vermelho

1) Percepção do parto:

- $O$ início do trabalho de parto (Primeiros sintomas e sinais)

- Motivação para a procura do serviço de saúde durante o trabalho de parto.

- O trabalho de parto (exames, medicamentos, outros procedimentos)

- Narrativa sobre o parto

- Problemas durante o parto

- Percepção dos problemas no parto

- Sentimentos e atitude em relação ao parto

- Familiares no parto

- Tipo de parto

- Duração do parto

- Situação do bebê ao nascer 


\section{C [2] HISTÓRIA REPRODUTIVA FEMININA}

\section{ASSISTÊNCIA.}

\section{1) Assistência na gravidez: — [Rosa]}

- Assistência pré-natal

- Local da assistência (Serviço de saúde)

- Tipo de assistência (Pública/privada)

- Motivo da escolha

- Percepção da assistência pré-natal

- Modelo assistencial

- Medicamentos usados na gravidez

- Exames realizados

- Procedimentos realizados

- Atitude frente ao atendimento

- Relação médico-paciente

- Qualidade do atendimento

- Esclarecimentos e orientações

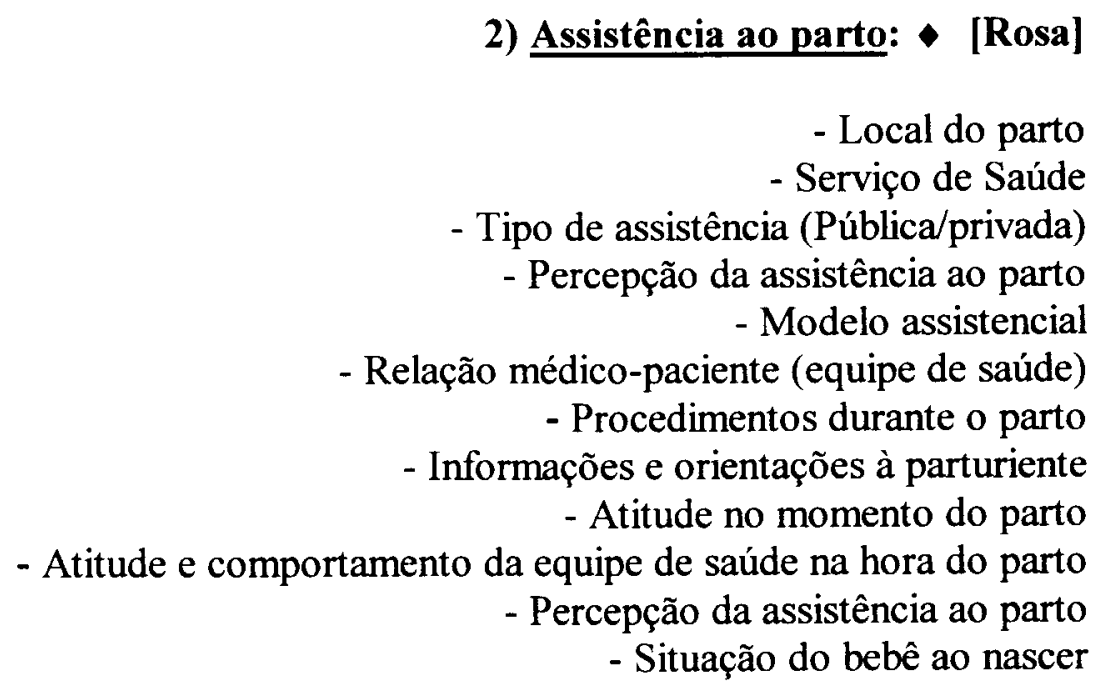

3. Assistência ao recém-nascido: - [Rosa]

Momento do nascimento;

Condições de nascimento;

Observações em relação ao recém-nascido;

Informações sobre o RN;

Sentimentos e atitude durante o nascimento do bebê;

Procedimentos em relação à criança após o nascimento 


\section{C [3] HISTÓRIA REPRODUTIVA FEMININA}

V. ANTECEDENTES $\bullet$ azu

1) Obstétricos - História reprodutiva anterior:

- Número de gestações

- Número de partos

- Número de filhos nascidos vivos

- Número de filhos nascidos mortos:

- Abortos

- Intercorrências ou complicações em gestações e partos anteriores

2) Antecedentes pessoais e ginecológicos:

- Problemas de saúde

3) Antecedentes familiares:

- Doenças na família

- Perdas na família

D. ESTRUTURAÇÃO E CONTEXTO SOCIAL E FAMILIAR.

\section{ESTRUTURAÇÃO E CONTEXTO FAMILIAR • [Turquesa]}

Situação conjugal;

Informações sobre o companheiro;

Convivência conjugal;

Acolhimento afetivo-emocional;

Relações sociais e familiares;

Maternidade e paternidade;

Informações sobre a familia de origem;

Outras perdas na familia de reprodução e causa da perda.

Perdas na familia de origem;

Comportamento materno e religiosidade 


\section{E. OUTROS TEMAS $•$ [Verde brilhante]}

\section{RELACIONADOS A ENTREVISTA:}

A fala da entrevistadora [inicio e final da entrevista].

Expectativas para aceitar o convite e para participar da entrevista.

Caracterização do método de trabalho.

A representação da entrevista.

Observações sobre a entrevistada. Apontamentos do diário de campo.

No relato da experiência - desvendar aspectos relacionados a:

[Definindo as categorias de análise]

O conhecimento de si.

A percepção do próprio corpo.

O cuidado de si. O cuidado consigo [Qual a diferença?]

O cuidado do outro - relação mãe-bebê.

O cuidado do outro - relação equipe de saúde -

Gestante/parturiente/puérpera.

Percepção da doença.

Atitude frente à doença. 


\section{ANEXO 7}

\section{ENTREVISTA $\mathbf{N}^{0} \mathbf{0}$}

[Cód. 0]

RECORTES POR ENTREVISTA

(Quadro unitário de análise)

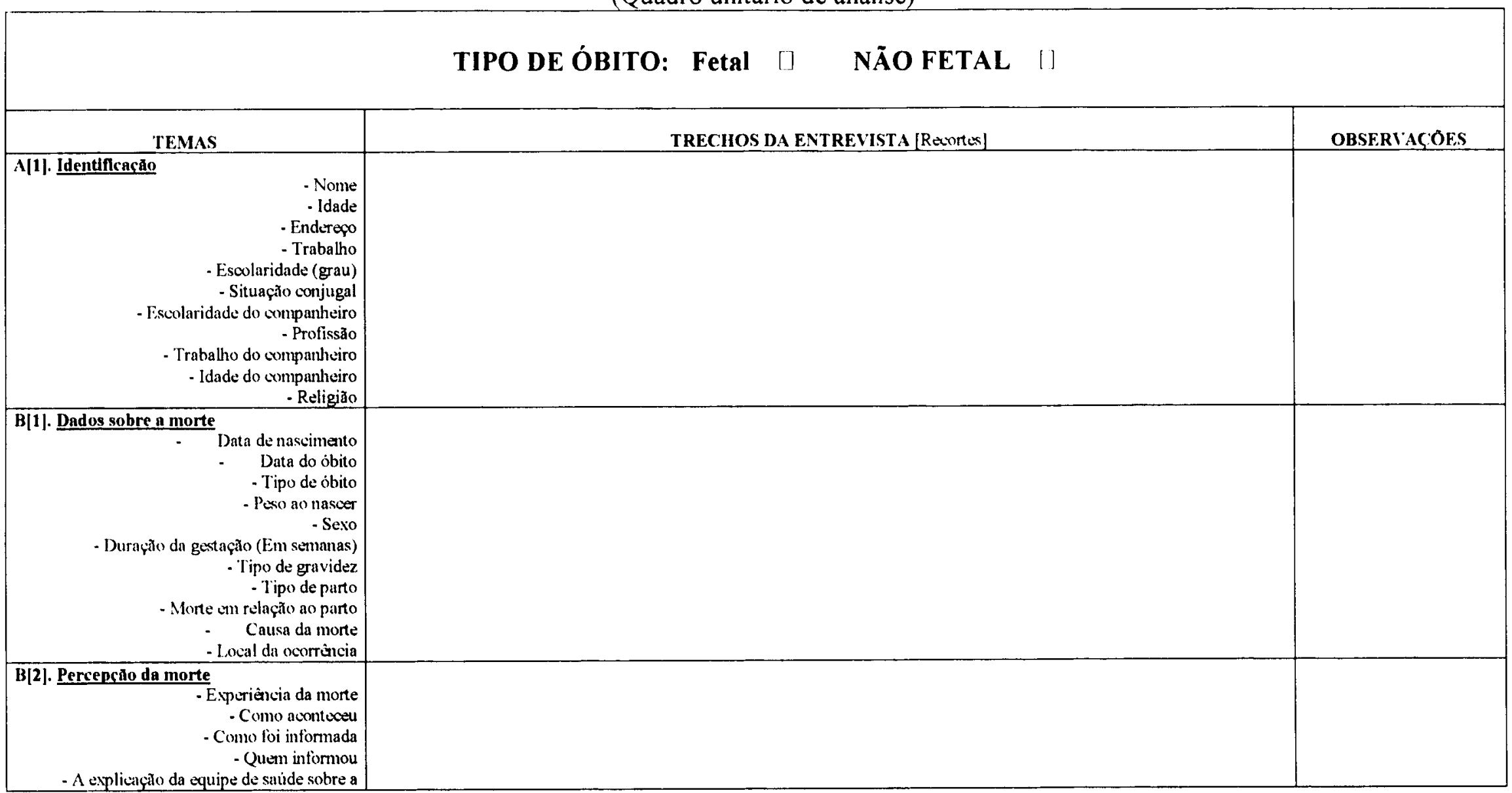




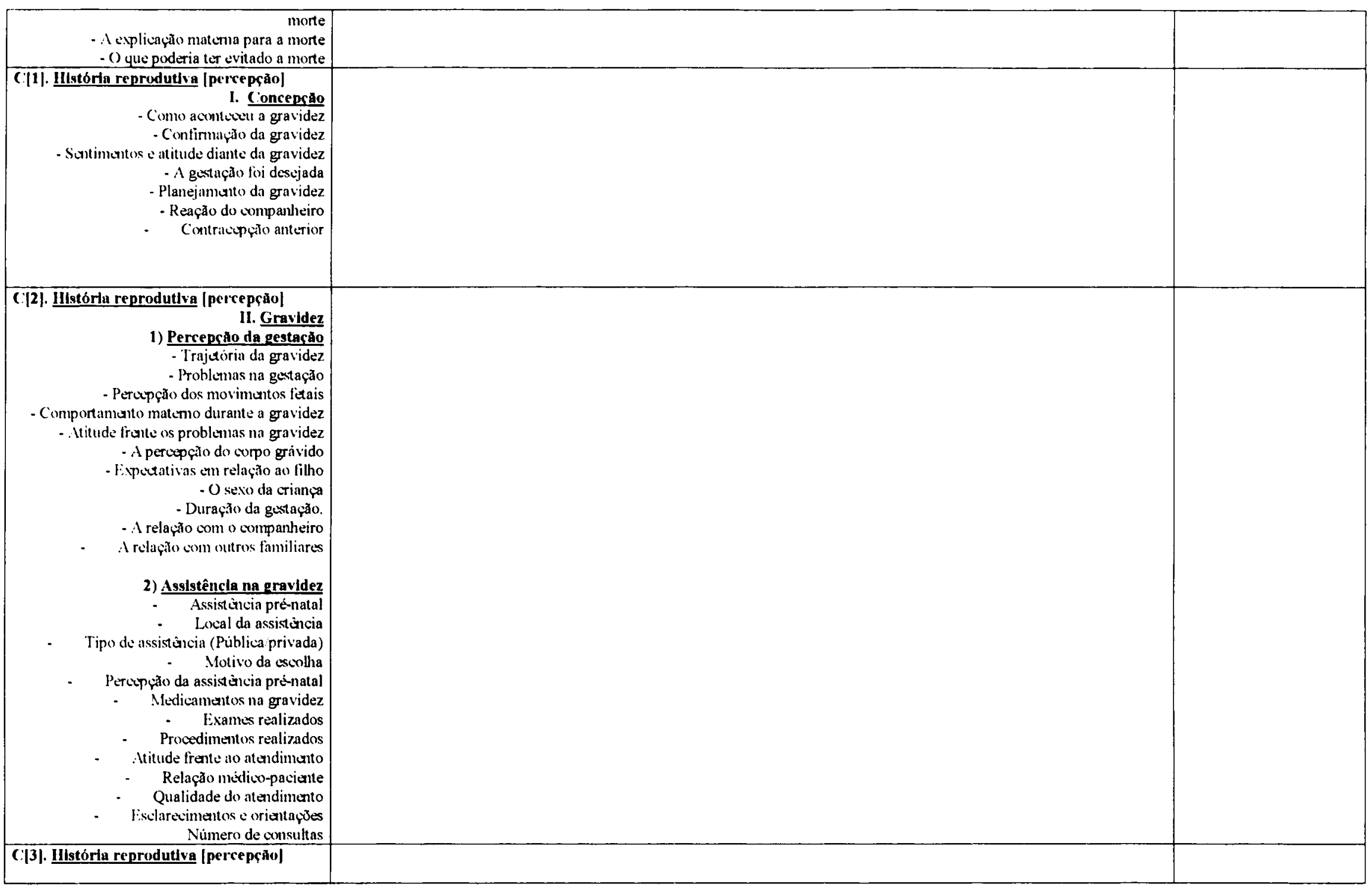




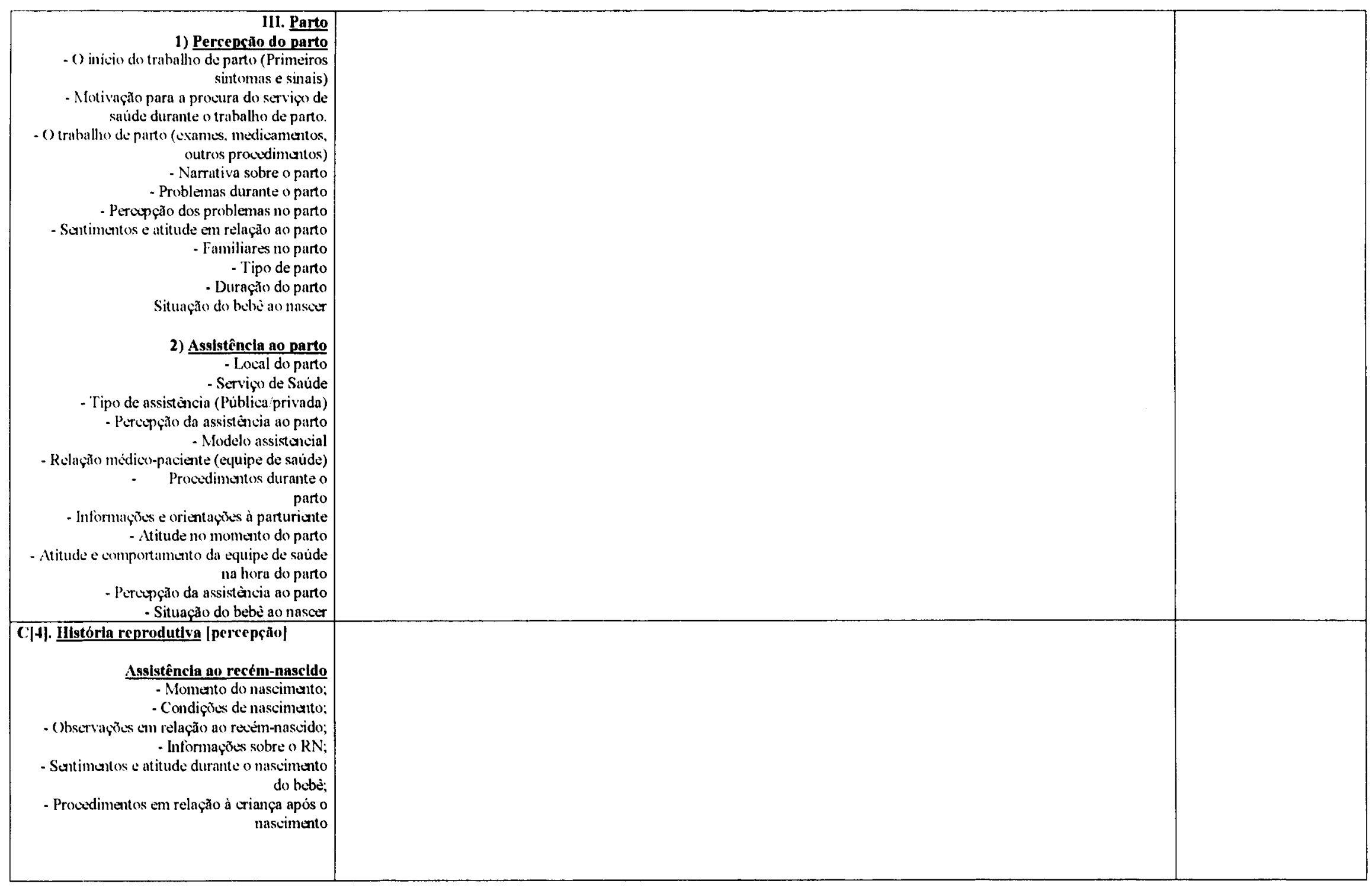




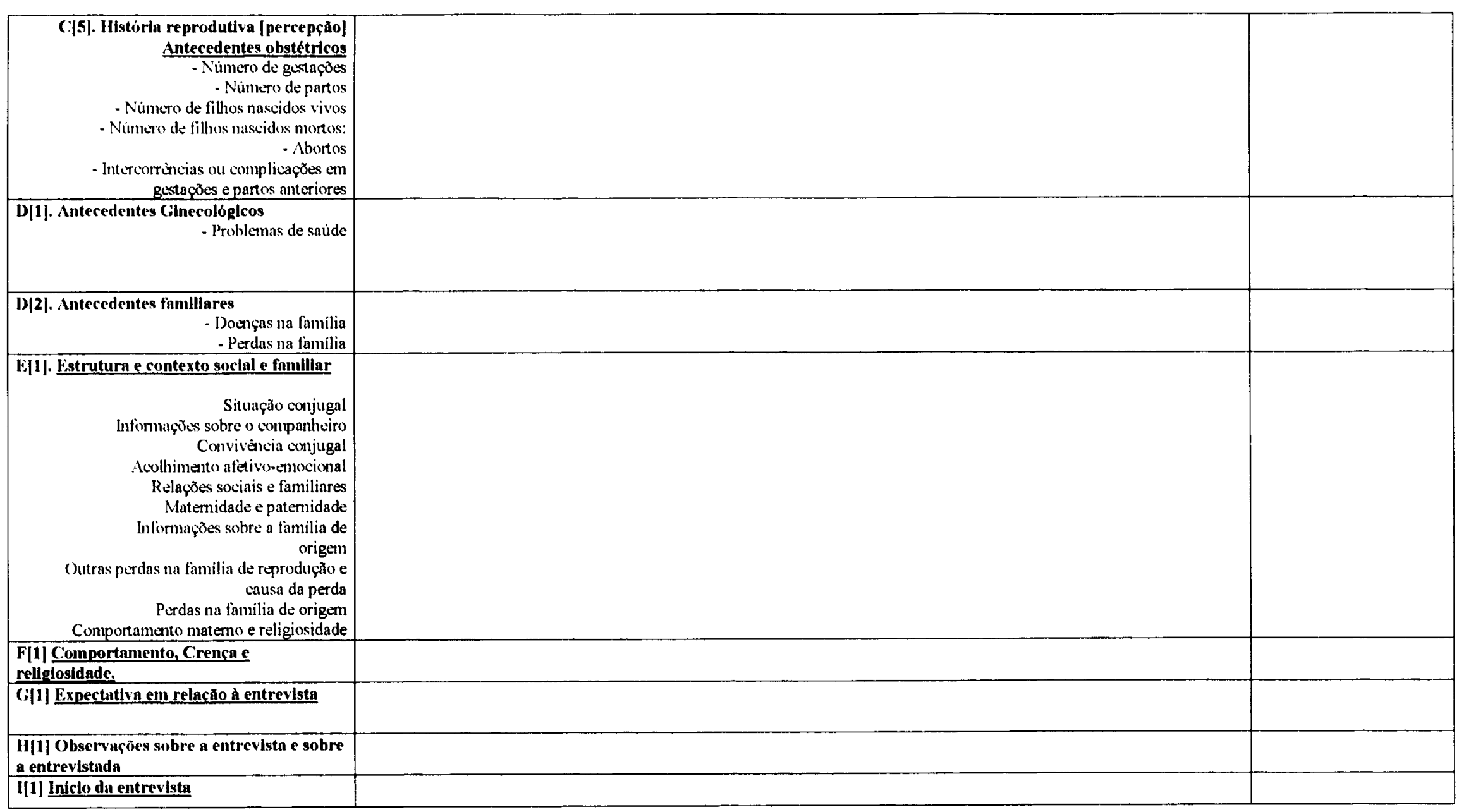




\section{ANEXO 8}

MATRIZ DE ANÁLISE

DELIMITAÇ̃ O DA PROBLEMÁTICA: "Percepçào matema da experiència da morte perinatal"

\section{A|1] IDENTIFICAÇÃO （Ruhricas temáticas)}

A|1].1 Identificacão pessoal (temas) : [Nome: idade: cndereço: trabalho: escolaridade (grau): eslado civil]. (especificações)

A|1|.2 Informações sobre o companheiro: [Idade: cxcolaridade: profissão; trabalho|.

\section{B|1] INFORMAÇÕES SOBRE NASCIMENTO E MORTE NO PERIODO PERINATAL}

B[1].1 Caracterização a respeito do nascimento e da morte perinatal (a partir da declaração de óbito): |T ipo do óbito (fetal. não fetal): data do nascimento: data do óbito (não fetal): local do nascimento: local do óbito (hospital. domicilio. outros...); peso ao naseer, sexo: duraçào da gestação (cm semanas): tipo de gravidez (única. dupla. tripla...): tipo de parto (vaginal. cesárco): morte en relação ao parto (anles e depois): causa da morte]

\section{B|2] EXPLICAÇÃO MATERNA PARA A MORTE:}

B|2].1 A experiência da morte: [Como acontoceu a morte: como foi informada da morte (circunstância): quem informou sobre a morte]

B|2].2 Atribuição da morte: [Fatalidade: gravidez não descjada: anuência divina (crença. conviç̧ão religiosa): problcmas transcorrido na gravidez (duração da gestação. percepção dos movimentos fetais. identificação dos sinais do parto): atitude durante a gravidez (procura por assistência pré-natal): atitude durante o trabalho de parto e parto (busca de ajuda. auxílio de familiares)]

B[2].3 Avaliação da assistência recebida durante a gravidez: [Assistência no pré-natal. o acesso e tipo de assistència (pública/privada): local da assistência: número de consultas: acesso a exames e outros procedimentos: uso de medicamentos: informações no pré-natal: relação com o profissional de saúde].

B|2].4 Avaliação da assistência recebida durante o pré-parto: [Recepção e atenção recebida no serviço (admissão. exame clínico. monitoramento do feto...): resolução do problema (vaga. condições locais de atendimento. internação. encaminhamento...): relação médico-paciente (acolhimento, apoio. explicações. orientação...): peregrinação da parturiente].

B|2].5 Avaliação da assistência recebida durante o parto: [Recepção e admissão da gestante no serviço de saúde: relação profissional de saúde-paciente: deteç̧ão de problemas durante o parto: agilização do atendimento: procedimentos (cxames. medicamentos. tipo de parto): condiçōes da assistência (material. competéncia profissional...): tipo de assisténcia (pública/privada): presença de familiar na sala de parto]

B|2].6 Avaliação da assistência ao recém-nascido: [Momento do nascimento: condiçôes de nascimento: observações em relação ao recém-nascido: informações sobre o recém-nascido: procedimentos em relação à criança após o nascimento]. 
B|2].7 A explicação do profissional de saúde para a morte: [Retradução matcrna do discurso tícuico da morte]

B|2].8 Percepção materna da morte: [O julgamento materno sobre a explicação do óbito]

B|2|.3 Evitabilidade da morte: |O que poderia ter cvitado a morte (maior cuidado consigo. maior atenção relativamentc aos movimentos fètais, informaçôes sobre riscos na gestação e no parto. melhor atenção do serviço de saúde (assistência adequada. atcução e cuidado dos profissionais de saúde. diagnóstico precoces. agilidade no atendimento), presença de lamiliar na sala de parto. confiança no profissional (atendimento ao parto realizado pelo mesmo profissional que fez o pré-natal): crença na anuência divina].

\section{C[1] ESTRUTURA E CONTEXTO SOCIAL E FAMILIAR}

C[1].1 Expectativas em relação à concepção: [Sonhos: fantasias: ideais: reação c expectativas do companheiro em relação à gravidez (apoio. compartilhamento...)].

C[1].2 Relaçōes sociais e familiares: [Relaçôes familiares (companheiro. filhos pais. irmãos): relaçâo com amigos: expectativas em relação à gravidez c ao naximento do fillho].

\section{D[1] ANTECEDENTES OBSTÉTRICOS, PESSOAIS E GINECOLÓGICOS}

D[1].1Gestaçōes anteriores: [Número de gestações: número de partos: número de filhos nascidos vivos; número de filhos nascidos mortos: abortos; intercorréncias ou complicaçôes em gestações e partos anteriores].

D[1].2 Antecedentes pessoais e ginecológicos [problemas de saúde].

\section{E[1] ANTECEDENTES FAMILIARES}

E[1].1 Doenças na familia de origem

E[1].2 Perdas na familia de origem 
ANEXO 9

MATRIZ DE ANÁLISE - RECORTE DAS ENTREVISTAS

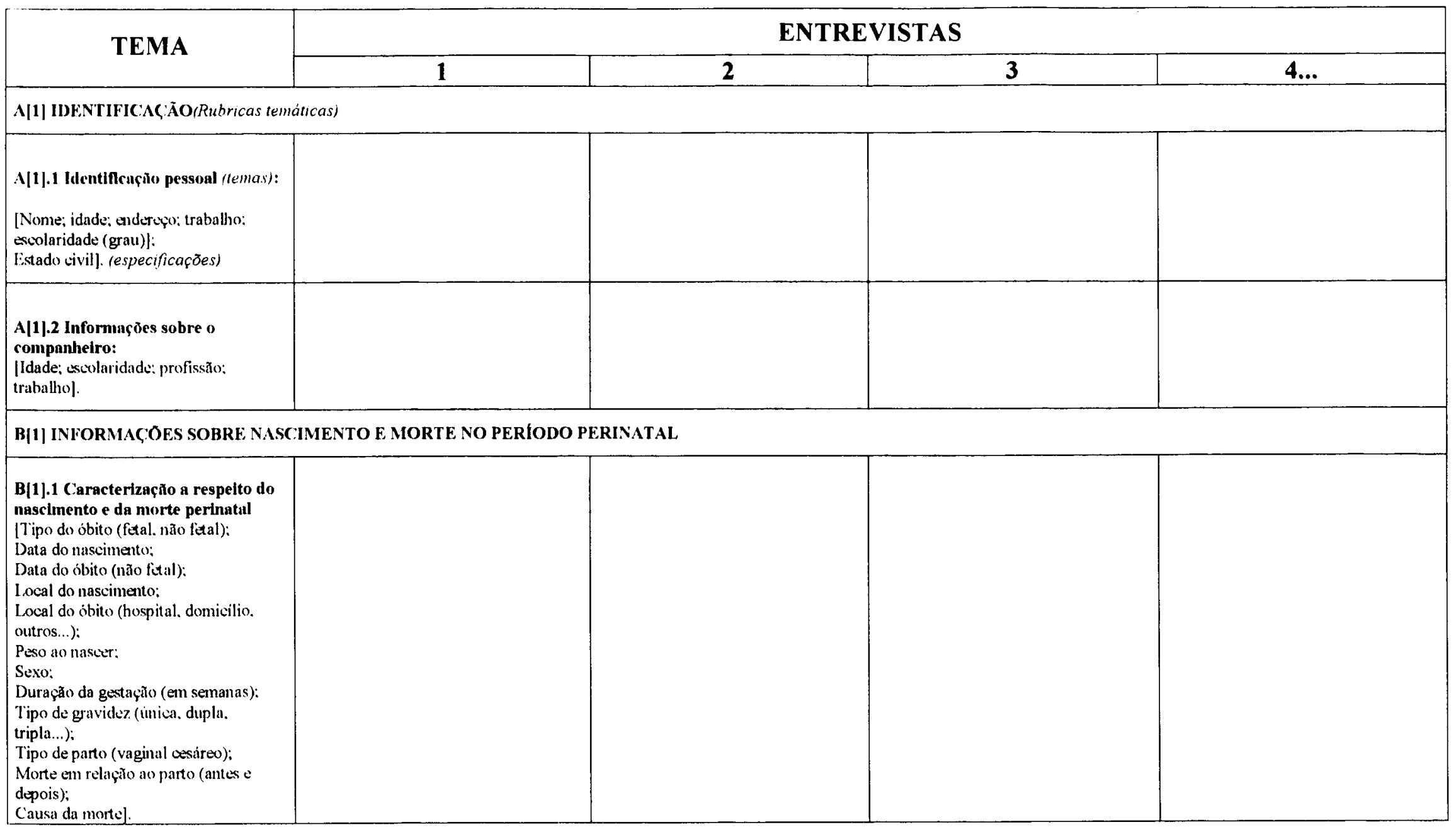




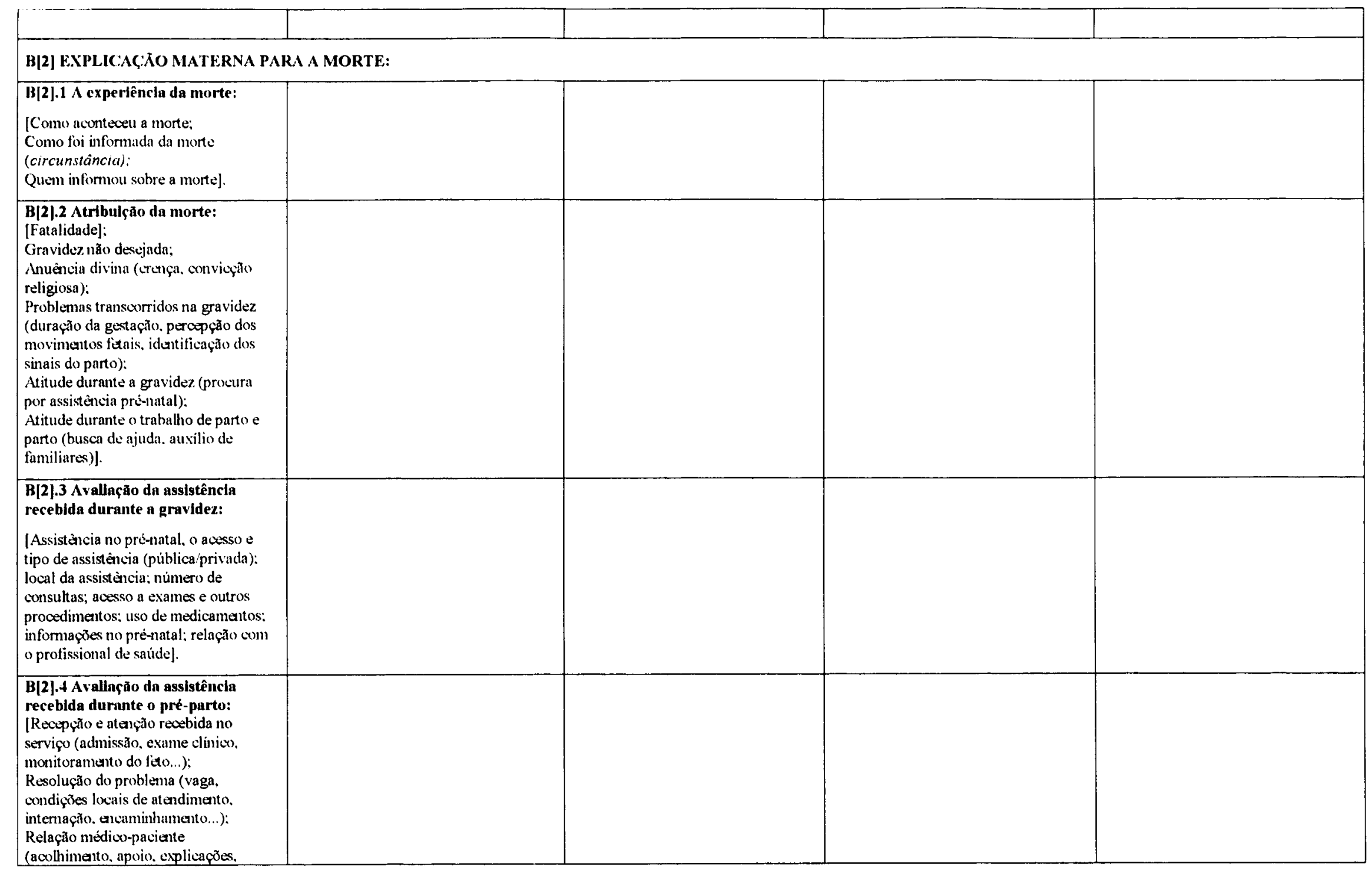




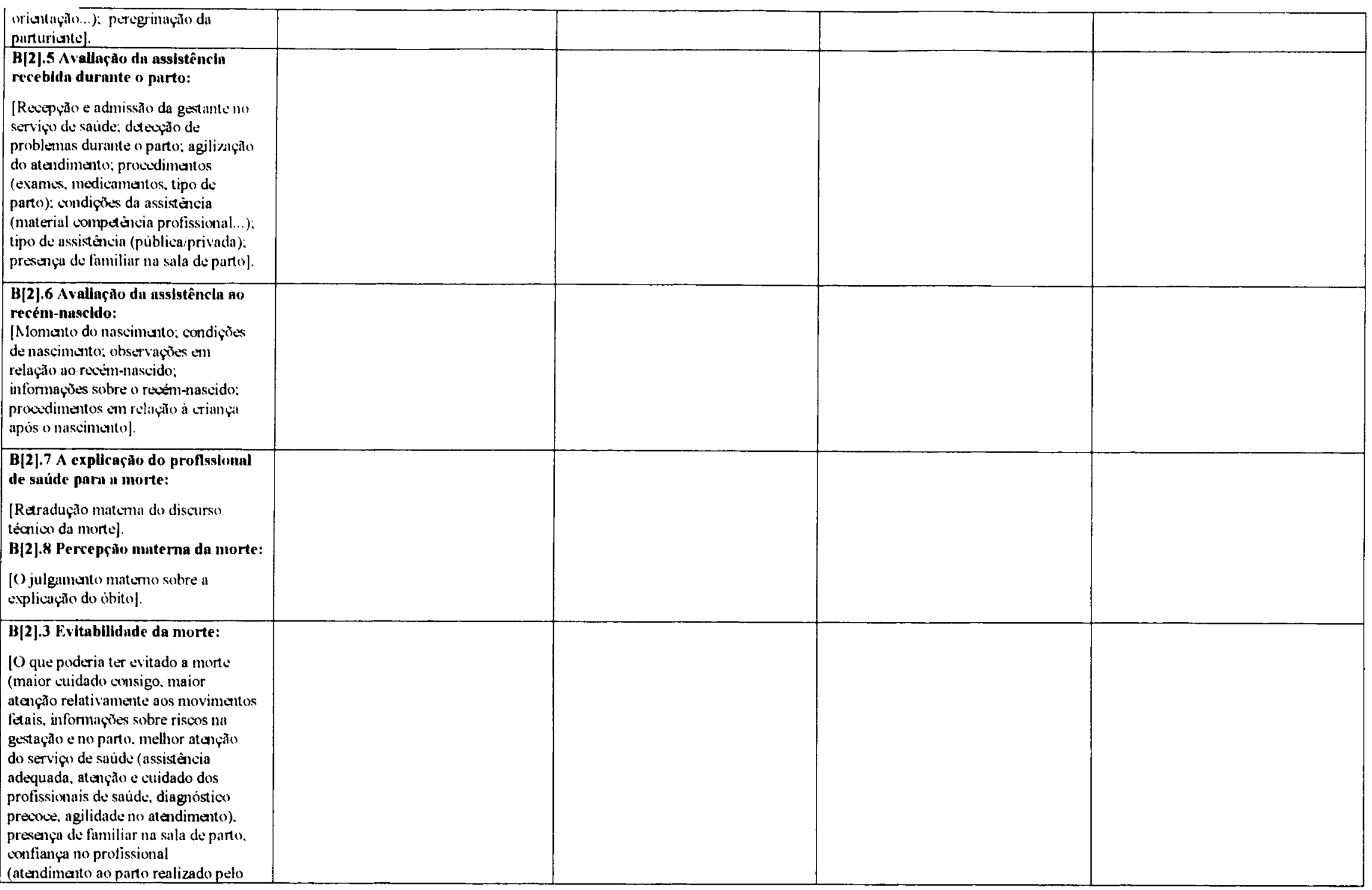




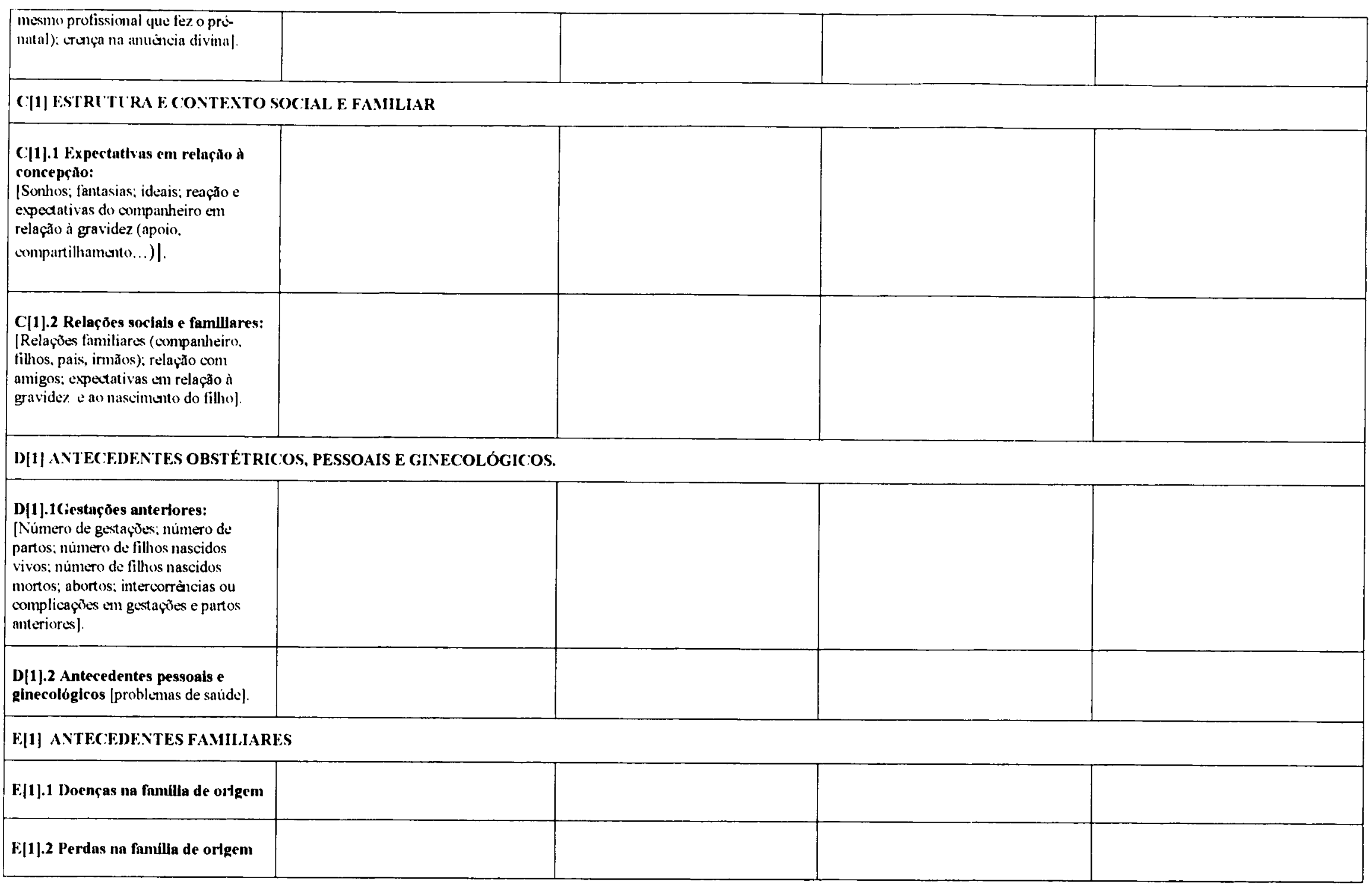




\section{CLASSIFICAÇÃo de REDUTIBILIDAdE doS ÓBITOS NEONATAIS, Fundação SEADE (Ortiz, 1996)}

\begin{tabular}{|c|c|}
\hline GRUPO DE CAUSAS DE MORTE & DOENÇAS CORRELATAS \\
\hline $\begin{array}{l}\text { 1. Reduziveis por imunoprevençào } \\
(\mathbf{0 1 0} \text { a }(018,771.3, \mathbf{0 5 2}, \mathbf{0 5 5})\end{array}$ & $\begin{array}{l}\text { Tuberculose, Tétano Neonatal, Varicela, Sarampo, } \\
\text { Rubéola Congênita }\end{array}$ \\
\hline $\begin{array}{l}\text { 2. Reduziveis por adequado controle na gravidez } \\
(090,760,761,765,769,773.0)\end{array}$ & $\begin{array}{l}\text { sifilis congênita, afecçoes maternus que afetum o feto } \\
\text { ou o RN, complicaçōes maternas da gravidez que } \\
\text { afetam o feto ou o RN, duração curta da gestação e } \\
\text { baixo peso ao nascer, sindrome da angústia } \\
\text { respiratória, doença hemolítica do feto ou RN devida à } \\
\text { isoimunização }\end{array}$ \\
\hline $\begin{array}{l}\text { 3. Parcialmente reduziveis por adequado controle } \\
\text { na gravidez (764) }\end{array}$ & Crescimento fetal lento e desnutrição fetal \\
\hline $\begin{array}{l}\text { 4. Reduziveis por adequada atenção ao parto } \\
(762,763,766,767,768)\end{array}$ & $\begin{array}{l}\text { Complicaçōes da placenta, do cordão umbilical e } \\
\text { membranas que afetam o feto ou o RN, duração } \\
\text { prolongada da gravidez e peso elevado ao nascer, } \\
\text { traumatismo ocorrido ao durante o nascimento, } \\
\text { hipóxia intra-uterina e asfixia ao nascer }\end{array}$ \\
\hline $\begin{array}{l}\text { 5. Rcduziveis por diagnóstico e tratamento precoce } \\
(770,771 \text {, exceto } 771.0 \text { e } 771.3,772,773 \text {, exceto } \\
773.0,774,775,776,777,778,779.4,779.5)\end{array}$ & $\begin{array}{l}\text { Doenças infecciosas e parasitárias, Neoplasmas, } \\
\text { Doenças das glândulas endócrinas e metabolismo, } \\
\text { Doenças do sistema nervoso, e dos órgãos do sentido, } \\
\text { Doenças do aparelho circulatório, Doenças do } \\
\text { aparelho respiratório, Afeccōes perinatais (outras } \\
\text { afeccões respiratórias do feto e do RN, infeccões } \\
\text { específicas do periodo perinatal, hemorragia fetal e } \\
\text { neonatal, doenças hemolíticas, outras icterícias } \\
\text { perinatais, distúrbios endócrinos e metabólicos, } \\
\text { hematológicos, pele e regulação térmica, sindrome de } \\
\text { abstinência de drogas, Causas externas, Anomalias } \\
\text { congênitas não especificadas }\end{array}$ \\
\hline 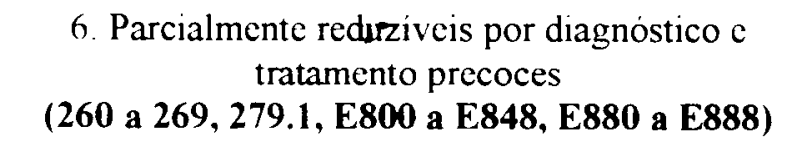 & $\begin{array}{l}\text { Reduziveis por medidas educativas } \\
\text { deficiências nutricionais, causas externas }\end{array}$ \\
\hline $\begin{array}{l}\text { 8. Mal definidas }(770,780 \text { a } 799 \text {, exceto } 779.4 \mathrm{e} \\
779.5)\end{array}$ & $\begin{array}{l}\text { Doenças com alta letalidade, sem possibilidade de } \\
\text { prevenção (anomalias congênitas de causa hereditária; } \\
\text { Ex. anencefalia, agnesia do pulmão, sindrome de } \\
\text { Patau, de Edward, etc) } \\
\text { Afeções mal definidas originadas no período } \\
\text { perinatal }\end{array}$ \\
\hline
\end{tabular}

Fonte: FUNDAÇ̃̃o SISTEMA ESTADUAL DE ANÁLISE DE DADOS - SEADE/SP

(1) Compreende os óbitos de menores de 28 dias

(2) Os números entre parêntesis correspondem a códigos de causas de morte estabelecidos pela Classificação Internacional de Doenças - CID.

(3) REF. BIBL: Organização Mundial de Saúde. Classificação Internacional de Doenças. Nona Revisão: 1975. São Paulo, Centro da OMS para a Classificação de Doenças em Português, v. 1, 1978. 